Soul Music Odyssey USA 1968 



\section{Soul Music Odyssey USA 1968}

[Second edition]

Jonas Bernholm

York University Libraries

TORONTO 


\section{(ㄷ) (i) $(2)$}

Soul Music Odyssey USA 1968 by Jonas Bernholm is licensed under a Creative Commons Attribution-NonCommercial-NoDerivatives 4.0 International License, except where otherwise noted. 


\section{Contents}

Preface vii

Introduction 1

New York (I) 4

$\begin{array}{ll}\text { Chicago } & 20\end{array}$

Memphis 86

$\begin{array}{ll}\text { Atlanta } & 147\end{array}$

$\begin{array}{ll}\text { Miami } & 169\end{array}$

$\begin{array}{ll}\text { New Orleans } & 199\end{array}$

Houston 280

Los Angeles 319

San Francisco 383

Detroit 413

New York (II) 419

Conclusions/Summary $\quad 454$

Postscript (I): Joe Tex 481

Postscript (II): Wilson Pickett 494

$\begin{array}{ll}\text { About the author } & 501\end{array}$ 



\section{Preface}

This is the complete book from my research trip 1968 (plus a little from 1978). The first version was basically a translation of articles written in Swedish and originally published in the Swedish magazine Jefferson (world's oldest blues magazine) plus a summary. It was published online by York University Libraries in 2017. This edition includes illustrations and corrections.

Special thanks go to Jan Kotschack, who digitized the photographs so they could be included online, and Rob van der Bliek, who copy-edited the manuscript and converted it to the online version.

Jonas “Mr R\&B” Bernholm

July 2019 



\section{Introduction}

I was born in 1946 in middleclass surroundings outside Stockholm, Sweden. Piano lessons in my youth went without any real progress.

Culturally Sweden was isolated with a state owned radio and later television with very limited output. It was like the eastern European states behind the iron curtain. At best, perhaps once a year a song with Louis Jordan or Big Joe Turner was heard on the radio.

Around 1956 records with Elvis Presley came to Sweden. Through my four year older brother I became absolute fascinated and soon had two other favourites whose records I also started to buy: Little Richard and Fats Domino. Still it was very rare to hear Jerry Lee Lewis or Chuck Berry on radio or in somebody's home.

With Elvis in the army and Little Richard quitting R\&R I lost interest around 1960 but after seeing the Beatles live in 1963 
- while in England studying English - I started buying records again and Chuck Berry in particular.

Back in England in 1964-65 and 1967 I was exposed to many English blues cover-bands like Manfred Mann, Pretty Things, Tridents, Ten Years After, John Mayall and I saw the Rolling Stones, Animals, the Who and Jimi Hendrix while they visited Sweden.

I started buying the originals with blues artists like Muddy Waters, Howlin' Wolf, Elmore James and Bo Diddley. From 1964 I was attending the American Folk Blues Festivals yearly.

Around late 1964 I heard soul records by Otis Redding, James Brown and Solomon Burke. I was not yet aware that these were brand new recordings while the best blues now released in Europe in most cases were recorded in the 1950s.

In the spring of 1967 the Stax-Volt tour came to Sweden. Up until that time I was not that much different from other record collecting teenagers. Collecting records have been the number one hobby in Sweden for decades. If you heard a great song on the radio chances were that you might never hear it again unless you bought it.

Having bought a fair number of recordings with Otis Redding, Sam \& Dave, Arthur Conley, Eddie Floyd, Booker T \& The MGs and the Mar-Keys I knew what to expect. But it was much better. I was ecstatic and made up my mind to go to America as soon as possible. 
SOUL MUSIC ODYSSEY USA 1968 • 3

A few months later James Brown came to Sweden. It was showmanship at a level never witnessed in Europe before. 


\section{New York (I)}

June $9-12,1968$

The English weekly music newspapers Record Mirror, New Musical Express and Melody Maker reported about the British invasion in USA in 1964-65. Artists were given a chance to fulfill a dream - to go to The Apollo Theatre. The Rolling Stones were completely ecstatic and Mick Jagger and Keith Richards allegedly said these famous words after seeing the Hardest Working Man in Show business, "You can put Chuck Berry, Jerry Lee Lewis and Little Richard on one half of the stage. No one is going to notice them when James Brown comes out on the other half.”

Elvis visited The Apollo Theatre, with Bo Diddley headlining, at his first time in New York when signing a contract with RCA Records.

Then the Beatles arrived and when exiting the airplane in England, George Harrison carried a Major Lance album under his arm while John Lennon praised soul singer Timmy Shaw's 
“Gonna Send You Back To Georgia” when the group was a guest with Swedish Radio host Klas Burling.

George Harrison was a true soul-connoisseur and voted for Bob and Earl's "Harlem Shuffle as Record" of the Year in Record Mirror's yearly poll (1964/65). At the same time Tom Jones (in the audience) was invited by Chuck Jackson to join him at the Apollo stage. Lennon had to wait until 1971 to debut there.

\section{USA 1968}

On June 9th, a Sunday morning, the plane landed at Kennedy Airport. It was two hours late and through a student counsellor I got the address to a cheap hotel - The Times Square Motor Hotel on 8th Avenue and 43rd Street. Despite very little sleep I didn't stay there long. I soon found myself walking in the direction of Harlem.

I stopped outside Jack Dempsey's bar in Times Square. The champ had not yet turned up to welcome his patrons. The early summer sun was filtering through the glass windows on a few guests.

I passed by Madison Square Garden.The debris from a huge boxing gala lay in droves on the sidewalk. As an avid reader of boxing oracle Nat Fleischer's columns in Swedish newspapers and his book 50 Years at Ringside I stopped again for a minute of silence and reflection before I continued to Central Park.

The sun was at its zenith and the park was full of people.The notes from the Intruders' "Cowboys to Girls” (a Gamble and Huff song) found its way from a transistor radio.The wind and 
the distance prolonged the interval between voices and accompaniment into a cosmic back beat. Everyone there; cyclists, thick girls and baseball players of different skin colours merged into it. I loved it - and soon found myself on the other side of the park.

Robert Kennedy had been shot a few days before, and was buried today. Three months earlier, Martin Luther King had been assassinated.

Many sad and hungover people were in a state of shock on Lenox Avenue. Nobody cared that a white guy was moving in on prohibited territory. Water hydrants had been opened and acted as public showers. A single luxury sports car slid slowly by.

Eighty blocks and a couple of hours later, I passed through people standing outside the Apollo on the sidewalk all the way up to the corner. Many were half asleep and stood perfectly still except that their heads nodded occasionally, at this meeting place for junkies.

I was in front of the Apollo Theatre on 125th Street. Time was around three o'clock in the afternoon. I read the following names on the classic marquee outside:

Jive Five, Jean Wells, The Spinners, the Delfonics and topping the bill: JERRY BUTLER.

I quickly hurried in, past this week's artist's publicity pictures, and bought the cheapest ticket at \$2. I had had already spent $\$ 14.75$ for the hotel and given 50 cents to a beggar. Not to 
mention the bus and taxi from the airport. It was expensive in America. (A freelance reporter for English soul magazines with a combined circulation of maybe 2000 copies did not get paid.)

In the hall there were also larger lobby cards with popular artists from the R\&B and Soul Hall Of Fame. I ran up the stairs to the second row balcony. It was a very steep balcony - Stories exist about ecstatic spectators standing on the railing to the tunes of “One O’Clock Jump” or “Flying Home.” Earl Hines Second Balcony Jump was based on a real event, it was said ...

I had timed my entrance perfectly in the middle of the opening act's first song.

On stage were the Jive Five. But they were only four, and these four men were moving in beautiful, intricate, synchronized movements poetically emphasizing the content of the lyrics. Their lead singer was Eugene Pitt. He was one of the founders of the group. They had lost the fifth member during their journey.

When they performed their last hit "Cry Like A Baby” (Musicor) they moved their arms tenderly from side to side, as if cradling/ rocking a baby, without standing still for a moment.

A young man, with a clean shaven, polished and shiny head (probably second lead singer Richard Fisher) was given more room on "Sugar (Don’t Take My Candy Away)" or "Strawberry Kisses” as I first thought it was called - after a prominent line. This was a very strong opening act. They had started as a doowop group but now moved into soul.

Jean Wells, a rather short, young lady made her debut at the 
Apollo with two great songs "Try Me And See" and "Have A Little Mercy." The latter was perhaps the highlight of the whole show. It contained dramatic lines such as the opening "I never ever thought I'd live to see the day.” Her performance was even better than the recording. She walked from one side of the stage to the other with the microphone cord hanging behind her. What an afternoon! All fatigue was blown away.

The next group on stage were The Delfonics. They were on the rise and very popular among girls who screamed their hearts out. They sang in falsetto, which in Africa can be seen as an expression of masculinity. They started with "I'm Sorry” which was a sequel to their biggest hit "La La Means I Love You" that followed. It was a polished group with a rather feminine appearance. The choreography was very elaborate but felt powerless compared to the Jive Five. Despite their newly found popularity they were the weakest act on the show. Over the next years, they became one of the bigger groups in the United States. They recorded in Philadelphia where soul was polished to a musically complex but often rather lifeless product. I felt that this was an attack on the true soul music of the 1960s.

Then came the comedian Arnold Dover. His main function was to give the Reuben Phillips Orchestra a well deserved and needed break to leave the stage and stretch their legs. His repertoire consisted of a fairly predictable mix of sex and race relation jokes. He imitated John Wayne, Billy Eckstine and Robert Mitchum and showed how a country boy who came to a big city dance hall behaved.

Time for The Spinners. They started with a rather weak version 
of "I Got Rhythm.” Everyone stood around the same microphone and sang in unison. It was barbershop and sounded like the Four Freshmen. Then came their showstopper - the Motown Impressions. They caricatured other Motown acts and performed some of their biggest successes: Four Tops: "Reach Out For Me, Temptations,” “Ain’t Too Proud To Beg;” Contours: “Do You Love Me;” Marvelettes: “Don’t Mess With Bill;” Miracles: “Mickey’s Monkey;” Supremes: "Stop in The Name of Love.” The potpourri seemed to be a few years old but it was greatly appreciated by the audience, especially their imitations of the girl-groups. They used the same number of singers as the groups had; five for the Temptations imitation and four for the Contours, the Four Tops and the Miracles and three men for the Marvelettes and the Supremes.

But they had saved the best for last: Stevie Wonder and Finger Tips. That must have been right on the dot. The crowd nearly fell out of their chairs in delight. My original notes suggest that after a while they continued with "Uptight."

The Spinners had not had a hit in a while, and it would take a few years before they had a second breakthrough. They were a highly skilled, professional and polished group, but I was a little surprised at their later successes as the show indicated that they wanted to take a place on the oldies and perhaps nightclub market. In 1968 the Spinners, whose first major success was winning the the Apollo Amateur Contest, was more like a local act that Apollo hired when they had no other in store.

Gladys Knight had been in the same situation a few years ago. These groups always did well and the Apollo kept them under 
their arms when they had no hits. When things were well again Apollo could always count on them performing at the Apollo, despite that they had better paid assignments waiting for them. In the early 1970s The Spinners and The Temptations broke the attendance records at the Apollo.

Jerry Butler was the main attraction and his set was longer. He did six songs on stage. He was a cool guy and had gotten the nick name "The Iceman” (hopefully before it had a connotation to hired assassins). He seemed to be on top of things and was later to engage in business activities. But despite being such as cool singer he spread a warm atmosphere in the audience.

After a long period of success at Vee Jay Records, he had made a comeback at Mercury with the Gamble and Huff team. His wonderful baritone voice can be heard on the Mercury successes "I Dig You Baby” and "Mr Dream Merchant;" "Never Gonna Give You Up” had just entered the charts.

Today he made an outstanding version of "For Your Precious Love" with a fine guitar solo and good versions of "The Look Of Love” and "Let It Be Me" and a great version of "He Will Break Your Heart.” Jerry had brought his own guitarist who also served as musical director for the Reuben Phillips Orchestra during his set.

This was black singing and a crystal-clear diction with a very talented singer who only on one occasion lost control. When Jerry sang the sentence "When you said you'll be my girl” from "For Your Precious Love” a young woman from the audience 
shouted out an ambiguous "When you sock it to me!” Then Jerry could not keep from laughing like the rest of the audience.

Before he started singing, he pointed out that it was now ten years and a day since he and The Impressions had started on the road to success with "For Your Precious Love" at this very stage. Then he sang to the reflecting light of a discotheque ball spinning around.

One can only criticize him for what he left out. Everything would have been perfect if he had sung "Moon River" and "I Stand Accused.”

The order of the songs could change a bit but the first show was like this: "I Dig You Baby" / "Let It Be Me" / "The Look Of Love" / "For Your Precious Love" / "He Will Break Your Heart" / "Never Gonna Give You Up."

Orchestra leader Reuben Phillips with his orchestra was in charge of the accompaniment of all singers. It was evident, but still OK, that the band had their musical background in jazz music. (I never counted the members but I think it was around fifteen.)

It was time for a movie break. Jack Schiffman has said about the Apollo films that they should simply be so bad that the audience cannot stand to sit and wait for the next show. The better the music, the worse the movie. Otherwise, the spectators could sit there all day on the same ticket.

When James Brown appeared they showed "The River," a more than one hour long film about water. Oceans with waves and 
rivers that flowed and sparked even the weakest of bladder reflexes so that those who were waiting in queues could take the places of those who went to the toilet.

Today's film was about a Swede on a ski holiday in Austria. Long ski scenes alternated with boring shots from the breakfast table at the hotel. It took a long time for the Swede to eat his breakfast and read the Huvudstadsbladet - the Swedish speaking newspaper from Finland.

It was a travel agency and tourist film that used to be shown for free back home. After seeing the movie twice I can't help thinking of this film whenever I see the Huvudstadsbladet. Which is not that often, luckily, as the paper is printed and read in Finland.

The second row balcony was an eagle's nest or rather a ledge for vultures. Here sat the theater's most critical spectators. The poor artist who did not find favour here was eaten up. Not one speck of flesh remained of his career, at least that day. But nothing happened when I was there. My focus was the stage. I don't remember what the crowd was doing. I saw the show twice. In principle, the shows were completely identical.

Suddenly I was back on the street again. The show was over. It had been a fantastic day but in the cool evening air, I regained my wit and senses. It was after eleven at night and dark and the atmosphere felt much more threatening than in the glorious sunshine in the afternoon.

Why had I not deposited my cash in the hotel safe? How could 
I be so stupid that I found myself in the middle of Harlem, after dark with all my funds, passport and tickets? I looked around ... Was there a metro sign somewhere? (But I did not even know then how it looked like.)

Who could I ask? To stand and wait at a bus stop might only make things worse ...

I started walking up 125th street but only after half a block I was hit on the back and one arm and heard a crazy scream in one ear. Half paralyzed with fear, I almost sank through the asphalt, when I saw an oddly dressed, middle-aged black, small woman with a big hat and the jerky movements of a mentally ill person, hurry past me. She disappeared in the dark. From Bobby's Records, on the other side of the street, I heard James Brown's latest hit “There Was A Time.” Then I discovered a sign saying "Metro" in the next street corner and paid 20 cents for the ticket. I was saved!

On Tuesday I bought a small transistor radio (\$13.50) from one of Times Square's radio businesses which have a continuous sale sign in the window.

I looked around in record shops and saw an almost complete range of all Atlantic LPs in mono (Ruth Brown, Clyde McPhatter, Clovers and Joe Turner, etc.) on sale for 1-2 dollars each. Mono LPs were purged from the US record stores. I decided to buy them all when I came back again, so I did not have to carry them around the USA.

I walked to Atlantic Records. I was unannounced but managed 
to have a brief chat with Bob Rolontz, the head of promotion. I booked a round-trip air ticket with stops in nine cities for \$317 (Chicago-Memphis-Atlanta-Miami-New Orleans-Houston-Los Angeles-San Francisco-Detroit and back to New York).

On Wednesday I went back to the Apollo. I wanted to see the legendary Amateur Night show. It was packed and I paid \$3 for a seat on the parquet. Audience reactions would decide who won. The names of past winners were presented on the screen - Ella Fitzgerald, Billie Holiday, Sarah Vaughn, Inkspots, Sonny Til \& The Orioles, Joe Tex, King Curtis, Chuck Jackson, Little Willie John, Gladys Knight and the Pips, Shep and the Limelites, The Clovers, Ruth Brown, LaVern Baker, Clyde McPhatter, Jackie Wilson, The Five Keys, James Brown and a few others who made it big later.

Many male and female sex-workers and transvestites had taken their seats and lodges in the first and second row. A forest of blond wigs were seen there. Not so visible were many representatives from record companies.

Showtime!

Honi Coles was the master of Ceremonies. He debuted in 1931 at Frank Schiffman's Lafayette Theatre, and was a tall, skinny dancer. He met Cholly Atkins (later Motown choreographer) when he toured with Cab Calloway's Orchestra (1940-43). They formed a dance team.

Honi Coles had been responsible for hundreds of amateur nights. They were first called the Harlem Amateur Hour, at the 
Lafayette Theatre between 11 and 12 pm every Wednesday evening; starting already in 1933.

(Readers may remember that Honi was portrayed in a TV dance program in the 1980s where Sandman Sims also demonstrated his sand-dance).

Honi and comedian Junkie Jones pulled a few bad jokes to get the audience in the right mood. It was election year (Humphrey against Nixon) and Junkie promised that if he was elected president, he would ensure not only "one chicken in every pot, but also some pot (= hashish) in every chicken!”

On the usually sparsely decorated stage a stump of wood was placed. It was the remains of the Tree of Hope that was planted outside the Lafayette Theatre. Nervous and superstitious competitors could "knock on wood” here.

The competition started, and Honi said that the Apollo audience had the reputation of being the very toughest, but if you won their heart, you could win everywhere.

First on stage was a young lady called "Timpy Lince” (all names in this section are phonetically spelled). She sang Aretha Franklin's Ain't No Way. She had not sung many lines when the audience began to applaud. Her voice was a fine mix between Aretha and Tina Turner. Definitely my favourite of the evening.

Next came Mark Liggins. With a very weak voice he started singing “I Believe," perhaps best known in Roy Hamilton's version. The audience started booing and he could not continue. Honi gave him another chance but after a while the booing 
was so loud that Junkie Jones rushed in with a gun wildly firing blanks. His costume was indescribable - he wore several brassieres outside a dress with floral pattern plus a bunch of rags in different colours. Mark stood frozen as a statue on stage, but when walking out he began to dance the mashed potatoes a la James Brown in protest. It looked really funny and the crowd started laughing and gave him their loud support again.

Next gentleman, Charles Holiday sang "For Your Precious Love.” It was of course stupid to follow the Jerry Butler original version in less than an hour. Charles tried to be different by adding kneeling, crying and screaming at the end. But the audience saw only the exaggerated and grotesque in this added James Brown drama. They had probably seen hundreds of James Brown imitators before. I thought it was good though.

Connie Singleton entered. She sang Aretha Franklin's “Baby I Love You.” Towards the end she lost her voice and became hoarse. But then the booing was loud too. It was a failure.

John Swan sang Bobby Hebb’s “Sunny," in the wrong key. The Reuben Phillips orchestra had to start again. The audience - of all ages - was disappointed.

A fool on the right side in the first balcony honked his horn (a trombone) when the singing or stage performance, in his opinion, became intolerable. The rest of the audience might shout and applaud or laugh, though. This was a big happening.

Janet Coleman, a roundish lady from Harlem, attacked Linda Jones "Hypnotized" but the audience was unimpressed. 
The next participant, Richard Brooks, looked like a winner when he nonchalantly danced around the stage. But as soon as he opened his mouth he was lost. The gunslinger rushed out on stage and scared him off with a burst of shots.

Jimmy McClinton from New Jersey sang “I Wish You Love” in a very professional manner, just like Nat King Cole. He looked very relaxed with one hand in his pocket, and silenced all the laughter and booing, which had grown to a hurricane during the latest performances. He received thunderous applause at the end.

Then it was time for the dancer Barbara Galloway. During her performance two wildly fighting men fell in from the side of the stage. A young boy called Little Jesse (12-13 years old) knocked on wood and danced very well for his age.

Charlie Henderson from Florida based his performance on James Brown's “There Was A Time.” He began by saying “I may not be like James Brown, but at least I'm on stage!” Unfortunately, he could not dance but was a good singer.

The final act had won last week's tournament. The group of four singers were appropriately named The Apollos. They had brought their own guitarist and drummer and did two numbers: "I Dig You Baby" - was almost on par with Jerry Butler's version, and a falsetto ballad was highly appreciated too.

Then the poll took place. The contestants getting the most applause won. These were the winners and in this order:

1) The Apollos

2) Jimmy McClinton 
3) “Timpy Lince”

4) Little Jessie.

The lucky ones, who won four times in a row, got a one-week engagement at the Apollo. The Apollos were already well underway. Despite what appeared to be chaotic and spontaneous, all involved in the Amateur Night followed a predetermined pattern that of course was difficult for the first first-time visitor to grasp. Everything seemed unpredictable and overwhelming. Alongside Honi Coles, who offered a brief dance number at the beginning, the most important roles were played by Junkie Jones and Sandman Sims.

The legendary Porto Rico, who first drove away the unsuccessful contestants by firing blanks, was a sound engineer. It is logical that the man with the most sensitive ears would object first. Eventually this part was taken over by Junkie Jones in the early 1960s.

The dancer Sandman Sims, with a trombone and wearing a sombrero, was sitting in one of the low set lodges to the right of the stage. He summarized the audience's reaction and alerted Junkie Jones.

Many big stars had their first breakthrough at Apollo's amateur night. This evening was perhaps an exception. I never saw any of tonight's contestants become superstars in the 1970s and 1980s. The show ended around half past twelve. Dazed and sweaty we streamed out into the humid Harlem night. The streets were full of people. It had been a very enjoyable night. There was so much 
happening - it is hard to imagine that the show only lasted a little over an hour.

It was time to go home and pack and leave for Chicago tomorrow. The Regal Theatre in Chicago was my second stop at the Theatre Circuit. Jive Five and Jean Wells were going there as well. Stevie Wonder, Shelley Fisher, Maurice and Mac and Detroit Emeralds joined them. 


\section{Chicago}

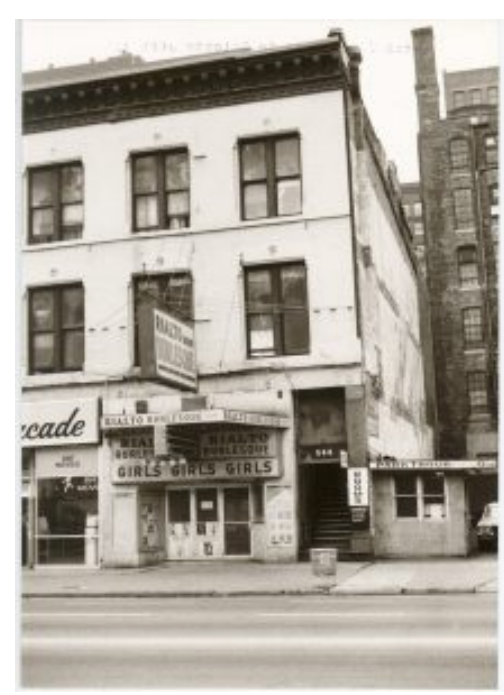

The New Leonard Hotel at 544

State Street, Chicago
June $13-26,1968$

The visit to Chicago was quite successful even if took some time to get to know the city. I made the mistake to arrive too close to the weekend and didn't have the opportunity to meet the right people to tell me what was happening. A couple of days were wasted when I ran around and never really found what I was looking for.

There were many artists from Chicago that I really wanted to meet and see in action. At least they recorded in Chicago but maybe lived elsewhere. I didn't know. The last couple of years a few great LPs had been released on the English President label. 
McKinley Mitchell and Alvin Cash had solo albums and then there was the collection with artists like Otis Clay, Johnny Sayles, Willie Parker, the Five Du-tones and last but not least Harold Burrage. There had been similar collections from the Chess/Checker labels but this was the hard gospel based soul I liked best.

Of course I liked artists like Jerry Butler, whom I already had seen at the Apollo, or Betty Everett, Gene Chandler, Dee Clark and Major Lance, but my biggest favourite was still McKinley Mitchell. I had seen Howlin’ Wolf, Little Walter, Jimmy Reed, Sonny Boy Williamson, Otis Rush, Junior Wells and Buddy Guy at the American Folk Blues Festivals. I had most records released in Europe with these artists. But many of them had obviously passed their peaks while many of the soul artists were at the height of their powers. And I wanted to see them.

Thursday, June 13

It was a rainy day in New York but the sun shone in Chicago when I left the plane. I had befriended Jim from Memphis on the plane. He had ridden for a while with the Hells Angels. The rate at the YMCA was \$4 per night. It was too expensive for me and I started looking in the back streets. Jim tagged along, but I started to understand that he was not a great follower of Martin Luther King. He would only detain me in my research. On a parallel street to South Michigan Avenue lay The New Leonard (544 State Street) with the moderate price of \$11.25 per week. It was integrated and most of their patrons were black. Jim left without a word when he realized this. 
Signs on the walls said that it was forbidden to drink alcoholic beverages in the rooms, or have other visitors than the legal wife. In fact not unreasonable demands as the original rooms were divided into half with masonite walls thus making the rooms totally lacking sound protection. The pendant lamp was just a naked light bulb lit by a string.

My next door neighbour, however seemed to be constantly drunk and the paper basket in the communal toilet and shower-room was always filled with empty bottles of classic port-wine and muscatel brands like Hunts White Port. I started to use that too and my favourite was Georgia Peach Wine. Sometimes I had to step over a one-legged war veteran from WWII or Korea who had passed out during his washing routine. His crutches and false teeth were on the floor.

A communal closet had a one flame gas stove for cooking. It lacked cooking utensils so once I put a can of pork and beans on it. When I came back after the shower it was missing. I cursed the dishonest patrons but eventually saw the exploded tin on the floor. The wall was full of beans and tomato sauce but it was not easy to spot among old stains already there ...

The staff was very friendly and helpful. I especially remember the clerk in the reception. He had his larynx removed and talked with the help of a vibrator held on his Adam's apple. Foreign tourists were rare here.

I checked the surroundings. Houses in the neighbourhood were run down despite the closeness to the city center. The Lexington 
hotel at (South) Michigan Avenue nearby, had been Al Capone’s headquarter.

Friday, June 14

It was time to get to work. My goal was to understand the whole picture of the soul music scene in Chicago by visiting clubs, record companies, recording studios and radio stations and meet artists, DJs and industry officials. My first stop was Chess Records at 2120 South Michigan Avenue. This address, which also was a title of a Rolling Stones' instrumental had stuck in my mind. But Chess had moved, with no forwarding address posted at the door. I walked by Vee Jay's closed doors at number 1449. They had been bankrupt since a couple of years and the premises had later been taken over by Dakar. Impulse had Gabor Szabo albums in their windows. A couple of ethnic companies were selling polka music. In the window of Bunky Records at 1421 were the cover of the Esquires' first album. Constellation Records had previously been a tenant there. (When I later met the Esquires, their bass-singer Mill Edwards/Evans told me that he was currently living at 627 East 87th in Chicago. I found Chess' new address and One-derful! Records in the yellow pages.)

I started feeling disappointed and lost and asked people for help. They recommended a visit to the Regal theater and to the entertainment district at the North Side of Chicago.

First I checked the North side and found the Happy Medium (901 N. Rush). The Younger Brothers’ name in big letters was on their marque. I had heard a fast, harmonica instrumental with 
them in Sweden. At other establishments I found nothing of interest.

I went to 47th Street and to 4719 S. Parkway and The Regal Theater. It was a pretty rough neighbourhood and had visible signs from the riots after the assassination of Martin Luther King three months earlier. It was in the afternoon. Children in dirty and raggedy clothes were playing outside.

I went directly inside when I saw the names on the marque:

Stevie Wonder/Archie Bell and the Drells/Jive Five/Detroit Emeralds/Jean Wells/Maurice and Mac/Shelley Fisher/Soul Crusaders Orchestra.

The ticket price was around \$2. The big room looked pretty worn down. I remember it as slightly smaller than the Apollo, but wider. Their chairs were more narrow and space for legs was less.

I took a seat to the left in the fifth or sixth row. The stage was pretty high up and my eyes almost at the same level sitting so close to it.

Shelley Fisher opened and he sang two numbers on the first show: "On A Clear Day" and "Swing Low Sweet Chariot.” At the second show he also did Lou Rawls classic about the tough life in Chicago, "Dead End Street," and also had the opportunity to dance a little.

I was not so impressed as his background was jazz and more for fans of Frank Sinatra and Nat King Cole. But he didn’t reach the 
heights of his inspirations. I later found a couple of records by him on VeeJay which were not very memorable either for a soul fan.

Maurice and Mac were next. They were Chicago's answer to Sam \& Dave. They had based their performance on them and Mac was a good enough dancer to almost fill the role. Maurice was a little hoarse that day and didn't really get a chance to show what a fantastic singer he is. Which everybody who has heard the Radiants recordings can hear. (But I was not yet aware of that both came from that group.) Their You Left The Water Running was

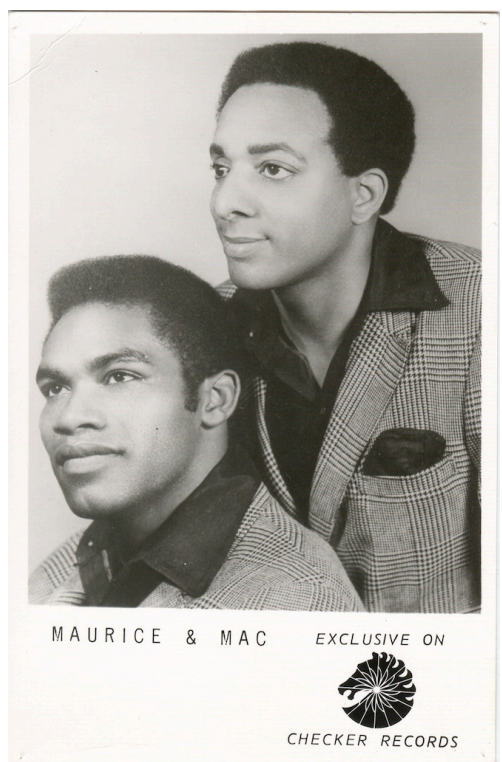

Maurice and Mac (Courtesy Jonas Bernholm) much heard on the radio then.

Jean Wells was at the second stop of her Chitlin' Circuit tour. Her performance was pretty identical to what she had done at the Apollo the week before (Try Me And See and Have A Little Mercy). Here she also did Giving Up that Gladys Knight and the Pips made early in their career. Jean's interpretation of this outstanding number confirmed my impression that she was one of the very best soul singers in USA. I saw this rather 
short singer on three occasions but I never took the chance to interview her.

Shout Magazine in England later published an article that I wrote with Tony Cummings that had some biographical data; She was born in West Palm Beach, Florida on August 1, 1942. After the obligatory learning period in different church choirs she debuted on record in Philadelphia 1959. (Many of my favourite soul singers happen to be from Georgia and Florida.)

The Detroit Emeralds were a great group with four fine male singers that had not gotten so much big stage practice yet.

First they did "Day tripper" and "Ode to Billy Joe" and then they asked the audience: "What time is it?!" Before the audience had a chance to answer they themselves did: "Showtime!"

"Showtime" was a great song that referred to Wilson Pickett, James Brown and Otis Redding and their recording successes. They recorded for Ric Tic, one of Detroit's best soul companies. When I started buying their records I never found "Showtime" despite the fact that it had entered Billboard's Hot 100 in March of 1968.

The Jive Five had accompanied Jean Wells from the Apollo theater and they again showed what a great group they were. Eugene Pitt sang lead on "Cry Like A Baby” and "Sugar (Don’t Take Away My Candy)” and the group member with a shaved head (not so common then) sang lead on "No More Tears” which had been added since the Apollo show and was just as good as their other Musicor recordings; their record company then. 
Archie Bell and the Drells never showed up. Their manager (Skipper Lee) later explained that it was a false group and that he had stopped them.

Now the curtain was closed. It was time for Stevie Wonder! (It was at this stage that he recorded "Fingertips" five years earlier.)

When the curtain was pulled aside he was sitting at his electric piano. He was one of the best Motown artists and his recordings were always of top quality.

First he sang and played "Shoo-Be-Doo-Be-Doo-Da-Day" and one about "The Life of Jimmy Brown." He then stood up and did the best song of the show: "I Was Made To Love Her." The excitement also mounted when he probably unintentionally almost tripped and fell over an electric cord. Stevie had brought his own musical director who also assisted him on stage. They walked to the drum set and Stevie did "My Baby." His drumming was much appreciated and he was taken back to the piano and did a number I think was called "Soul Talk" where he played chromatic harmonica just like Toots Thielemans.

He closed the show doing 'Uptight' standing up behind the piano. Musically it had been quite satisfying but he was not a great performer and he was unable to connect with the audience like Ray Charles. He simply didn’t seem comfortable on stage. I was slightly disappointed and he didn't do any better at the second show. I had probably seen the very first performances of this week at the Regal Theatre. Jean Wells and the Jive Five came directly from the Apollo where a new week also started on the Friday afternoon. The others had probably rehearsed the 
show yesterday and today. In fact the Soul Crusaders Orchestra seemed a bit tired.

My lasting impression was that the Apollo shows were slightly better. They focused more on the small details trying to make everything perfect. I guess the Regal show improved as the days passed. (The owners later went bankrupt and the Regal was closed in 1968 and the building was torn down in 1973.)

\section{Saturday, June 15}

I went to Chess Records new address at 320 East 21st St. It was closed on weekends but the reception was manned and there were a couple of people in the foyer. I was not able to get their attention and was only answered very briefly so I left.

I had found good soul music on station WVON at $3350 \mathrm{~S}$. Kedze. It was my next stop but I got lost and never found it. I had also noted that the Ter-Mar studios where Chess recorded were at 2030 S. Calumet. But I never came there either. Instead I more or less wandered around aimlessly and found nothing of interest.

What to do tonight? I was again following a recommendation by someone in the street to go to the North Side. I found a club with a Louis Prima inspired trumpeter. His gift to musical history might have been playing on two trumpets simultaneously but it felt like a wasted day. Where were all soul artists?

On my way home on S. Michigan Avenue, near my hotel, there was a jazz club. The door was open but the orchestra had taken 
a break. I walked in and was almost immediately approached by a woman selling sex. So I left.

Sunday, June 16

Rather aimlessly I went out early looking for a black church. But the people standing outside seemed very well-adjusted and middle class and for some reason I did not feel welcome or comfortable and I left.

I later found myself at an outdoor concert at South Parkway. It was not good enough for me to take any notes. At night I went to The Club (5523 State St).

I had seen a poster on the town and made an association to Little Milton singing "Welcome To The Club” (original by Lee Shot Williams). It was a jazz club with a small cocktail drinking clientele. The revue had a jazz combo, a couple of pretty sophisticated vocalists, a comedian and a couple of dancers. The night was hosted by the conferencier from the Regal Theatre and we talked a little.

With audience sounds and ice cubes in drinks it was as close I got that summer to Ramsey Lewis' “The In Crowd” (or to similar music by the Young Holt Trio).

I was not happy with this day either.

Monday, June 17 


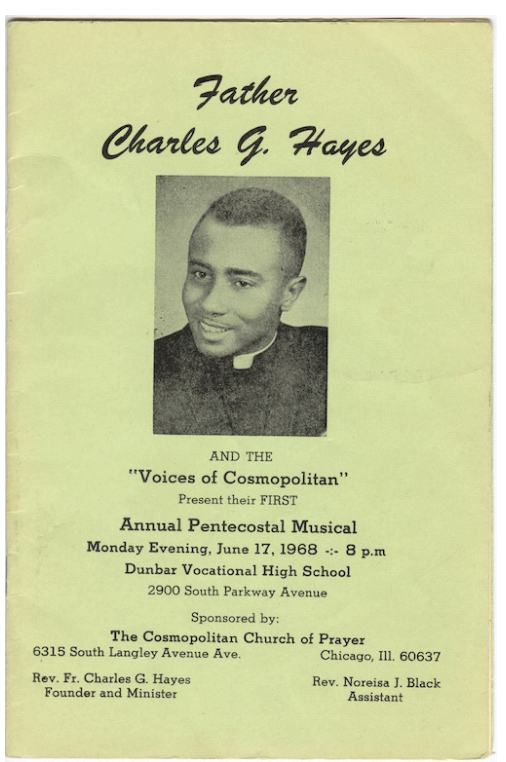

Pentecostal program

During my Sunday walk I had seen a poster about a gospel concert where The Mighty Voices of The Tabernacle and Professor Charles Taylor \& The Taylor Singers were the major attractions. It took place at Dunbar Vocational High School on 2900 South Parkway. Barbara Acklin and Bobby Rush had studied there before.

The school was located in a well-to-do district and the audience seemed affluent too. They was quite well dressed and many wore fur coats in the middle of summer.

Before the first part of the evening Father Hayes welcomed the audience and the artists and read from the bible. This was the first annual Pentecostal Musical there. Then Bob Weaver from radio station WBEE took over.

The Voices of the Cosmopolitan were first. This forty-member choir resided in Father Hayes church. Their lead soloist Cynthia Price sang like Aretha Franklin. She was quite good and if desired could be a fine soul singer.

Delois Barrett Campbell \& Barrett Sisters followed. They 
sounded fine and reminded me of the Soul Sisters that had records out on English Sue Records and a following there.

Professor Taylor sang and played the piano. Behind him stood a small group of female singers. And when the holy spirit filled him he rose up and danced - not unlike James Brown. A fine performance.

The Mighty Voices of the Tabernacle from Detroit closed the first part of the show. Their leader and conductor (Charles Prey?) also danced around on stage.

After a short break all artists did another set. But at the very end it was announced that a surprise guest was there. Charles Hayes walked forward to the end of the stage and pointed at a woman. It was Mahalia Jackson! Charles pretended that he was as surprised as we to see her there and after a little persuasion Mahalia walked on stage.

When she started singing it was like an electric current had hit the audience and a hurricane hit the building. People rose up, clapped their hands and screamed.

My next seat neighbour, a conservatively dressed young man in his best suit and in my own age raised his hands in what looked like a black power salute. He rose up and started running but tripped on

my feet and fell to the floor. Pentecostal program

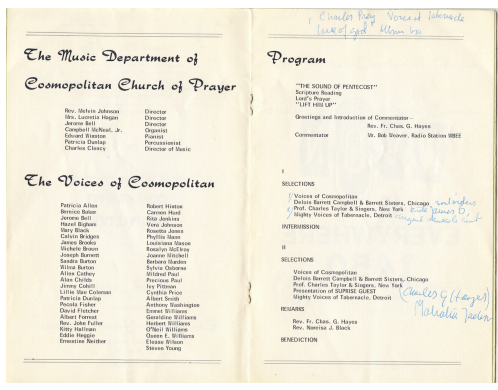


Then followed what seemed like a grand mal epileptic fit. I was worried. Two to three nurses were now running around helping people in the stalls. But I saw none in the balcony where I sat. Mahalia sang two or three numbers and finally my neighbour came through. He sat up with a smile on his face. He was certainly not a case for the medical sciences. He had been hit with a healthy dose of the Holy Spirit. And all the commotion and all the people who fell out in ecstasy had only increased this excitement. This was my first ever gospel concert or should I say school concert. The world's greatest gospel singer is there and sings. In fact the best female singer in all categories of the 20th century!

My luck had turned. I was on the right track.

Tuesday, June 18

The radio worked well all summer. Whenever hearing something worthwhile on the radio I wrote down the name of the artist and song and passed judgement in my 8 graded scale. The radio was always on when I was in my hotel room whether I corrected and rewrote my interviews or ate.

WVON was the station I listened to most. And WGRT, which had slightly better music.

These songs, that I heard in Chicago, were worth buying. My special favourites of these new discoveries have a *

"Working On A Groovy Thing” - Patti Drew "Save Your Love” Bobby Bland "What Is This" - Bobby Womack (*) "Slip Away" Clarence Carter "Grazing In The Grass” - Hugh Masakela "Love 
Makes A Woman" - Barbara Acklin "Security” - Etta James

(*) "Paying The Cost To BeThe Boss" - BB King "There Was A Time" -JamesBrown “DarkEnd Of The Street”-LittleMilton(*)“(YouKeep Me) Hangin On” - Joe Simon "Tuff Enough" - Junior Wells“Never Give You Up” - Jerry Butler “Turn On Your Love Light” - Bill Blacks Combo “I’m Getting Along Alright” - Raelets “Here Comes The Judge” - Pigmeat Markham “IKnow ICan” - Esquires “You'reLosing Me” - Barbara Lynn "Satisfy My Soul” - John Brown "I’m Sorry” Delfonics "Here I Am Baby" - Marvelettes "Soul Picnic" - Fifth Dimension “He Don’t Really Love You” - Delfonics “Got To Have Money"-Bobby Welch "Save Your Love"-Solomon Burke "IWanna Know” - Jimmy Soul Clark"River Of Tears" - Gene Chandler "It Should Have Been Me” - Gladys Knight \& The Pips“Tell Me The Truth”-Billy Stewart "Stay in My Corner”- The Dells “The Woman I Love”-BB King "My Kind Of Woman”- Jimmy McCracklin "Yours Until Tomorrow” - Vivian Reed “Two Can Make a Couple” - Johnny Kirk \& Lily-Ann “Working On A Groovy Thing”-Miss Danny Bruce

Every tenth song on the radio was by James Brown. Aretha Franklin was very often heard too. There was a lot of Tamla Motown material and light weight soul. The deep, heavy, hard gospel styled soul was more of an exception. At every soul station you could hear songs not heard else where. In Chicago but not in other cities I heard for example John Brown, Bobby Welch, Johnny Kirk \& Lily Ann and Miss Danny Bruce.

Today I went directly to One-derful! at 1827 S. Michigan Avenue. The office was a couple of kilometers from my hotel. Present there was Eddie Silvers, their musical leader, and after a while the owner George Leaner showed up. They seemed 
happy to see me and asked what had brought me there. I told them about the profound impact the records on their labels Onederfull! and Mar-v-lus and M-Pac had made on me.

My own favourites were McKinley Mitchell, of course, and Harold Burrage, plus Otis Clay, the great Johnny Sayles and Willie Parker's fantastic You Got Your Finger In My Eye etc. The blues recordings from Chicago in the mid-60s didn't have the same intensity as these artists.

Betty Everett, a great Vee Jay star, had done very well with Your Love Is Important To Me on George's company.

Alvin Cash and the Crawlers (or Registers) with Twine Time and Alvin's Boogaloo were just as good as - or even better - than Booker T. and the MGs.

One-derful!'s office and studio were on the first floor and below, on the ground floor were United Record Distributors office and warehouse. It was run by Ernie Leaner, George’s brother.

Eddie Silvers showed me around. Their studio laid empty. It seemed no new recordings were planned. 


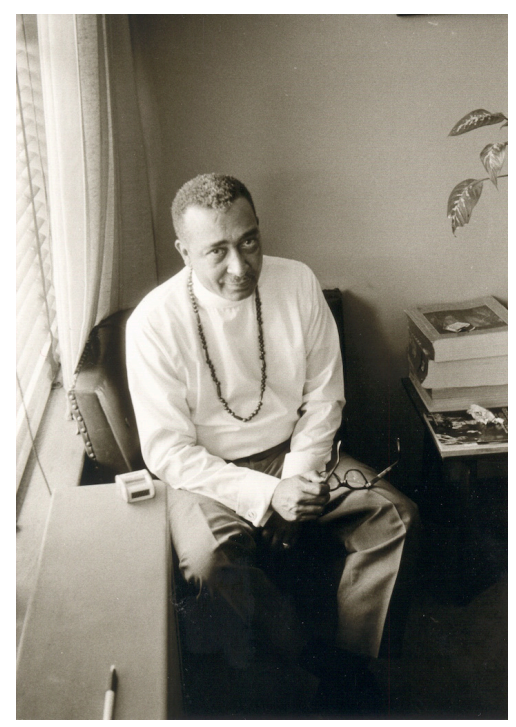

George Leaner

One-derful! became my headquarters in Chicago. George Leaner was always welcoming and liked to talk about black music and culture, even if my language skills were not always on the level that I could follow. In fact the staff was so nice that I didn't bother to go back to Chess, where both Johnny Sayles and McKinley Mitchell had tried their luck after One-derful!.

When I told George about Mahalia Jackson he said that she's a very unhappy woman.

But at my first visit I wanted to know where I could see all these fantastic artists live. In fact all others singing in the same style.

Harold Burrage was dead. His heart had been weak. His recordings of "Got To Find A Way" and "Master Key” had made a big impression on me. McKinley didn’t work much anymore but I got his phone-number and address. I also got the number to Willie Parker.

Otis Clay was not in town. George sounded sad when he told me that he had lost him to Cotillion records, a subsidiary to Atlantic Records. His first recording, Sir Douglas Quintet’s She’s About 
A Mover, was getting airplay in the southern states during my continued travels.

Billy “The Kid” Emerson only appeared at very small clubs. It was difficult to find out where he was, said George.

Sometimes there were a drop of bitterness or sarcasm in his voice when George talked about the music business. He had stopped going to clubs.

McKinley had been the biggest club draw in Chicago for a short while. Then the fans flocked where ever he appeared. George was born into show business. Artists like Billie Holiday stayed in the Leaner home while on tour.

He promised to try to get Alvin Cash and McKinley Mitchell to the office so I could interview them.

George also recommended me to see his former right hand - a woman in her 30s - who had opened her own business in the same block. She was getting ready to meet people in the business to launch her own record company and artist Bobby King.

High Chaparral and the Scott Brothers Revue

That night I went to High Chaparral. One of three recommended soul clubs. It was a very big place and could probably hold 1000 (seated and standing) customers. First I entered a room with tables and a big bar and then a staircase led to the dance floor. There tables were located around a square stage which looked like a boxing ring without ropes. This was the place that 
Bobby Bland used to appear at, and Sam \& Dave and even James Brown before they got too big.

Not many people were there. Only the tables directly around the stage were occupied.

The Scott Brothers started the evening with Alvin Cash's Keep On Dancing and Cliff Noble's The Horse, and Moaning And Groaning.

During The Horse the Go Go Dancers Vickie \& Joy shook their hips energetically. Then Scott sister Irene Scott did Aretha Franklin's “Ain’t No Way” and continued with Aretha's sister Erma's “Piece Of My Heart” plus “After Loving You” and "Knock On Wood.” The Scott Brothers did a medley called "Got To Get A Groove” that gave Vickie \& Joy plenty of room. They were also called the two T-s and one was skinny and the other chubby. They didn't stand still in one place but walked back and forth along the sides of the square stage swinging their hips keeping time with the music.

The comedian Manuel Arrington gave the musicians a chance to rest during a comic interlude before he presented the members of the Revue as the "Doctors of Soul."

Then it was time for James Bennett, who like so many others that summer was an able James Brown imitator. But he declared that he was more comfortable with slow numbers.

He did:

Sam \& Dave’s “Soul Man”Walter Jackson’s “Speak Her Name”James 
Brown’s “Lickin’ Stick”Lou Rawls' “Love Is A Hurtin’ Thing”James Brown's “There Was A Time”

The six members of the Scott Brothers deserve credit for a job well done this evening.

It had been enjoyable but without any extraordinary experiences.

Wednesday, June 19

I tried to get hold of Willie Parker on the phone (815-723-6553) mornings and afternoons, but he never answered. Perhaps he was at work in Joliet, Illinois where he lived. I went back to Onederful! and interviewed Eddie Silvers and had a long talk with George Leaner.

Eddie Silvers was born in Kansas City 1928. He was a reed man playing saxophone and flute. He was married to Mary Brown born 1941 and one of the earliest members of the Ikettes. They had met

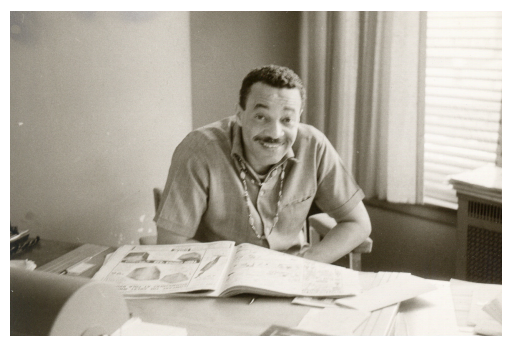

Eddie Silvers when Eddie was playing with Ike Turner. But first he started with Big Joe Turner and then (1954-1956) was with Paul Williams and 1956-1959 with Fats Domino.

In 1959 he joined the Upsetters, Little Richards former backing group which continued on their own after Richard had quit show business. Then followed Ike Turner's Kings Of Rhythm during 
the time Ike \& Tina had a giant hit with It's Gonna Work Out Fine.

Later Eddie worked with Bill Doggett, Jackie Wilson and Sam Cooke. He can be seen in the films The Big Beat and The Girl Can’t Help It.

He had also worked with Little Johnny "Part Time Love” Taylor and was arranger and musician at Duke/Peacock Records. For example on a session with the blind singer Clarence Carter, probably when he was a member of the duo Clarence and Calvin.

Nowadays he used to play with Mighty Joe Young during weekends.

During his time with One-derful!/Mar-V-Lus Eddie worked as an arranger for Alvin Cash and Otis Clay and others.

He was also a song writer. He especially mentioned the song Big Boy that he had arranged and written for the group The Jackson Five. I had never heard about them at this time. "It was their very first record," Eddie said. "A group of young boys and the lead singer looks like eight years.” (Later, I have always thought that Eddie was talking about "I'm A Big Boy Now" which the Jackson Five recorded a little later for Steeltown. But an article in Washington post by Aaron Cohen in 2014 announces that the original Big Boy had been found in the One-derful! vaults. Wikipedia says that Ed Silvers is the composer.)

Eddie also mentioned that many of his contemporary musicians had thought that they needed drugs like Charlie Parker to be 
outstanding. I also wrote down the names of Miles Davis, Cannonball Adderley and Brother Jack McDuff. I guess that he had also played with them, or that they were among his favourite musicians.

I told him about the poor reception I had received at Chess Records. He suggested I contact Marshall Chess, the son of the Chess brothers or Ralph Bass there.

I always used to asked everybody I met about James Brown and Ike and Tina Turner. Ed simply said that Ike was a mean character. While George Leaner added that James Brown probably was much older than everybody thought. He was supposed to have appeared in a circus as a child as early as 1928. Now he was in his mid forties.

Eddie also wrote down names of recommended clubs to visit:

Bonanza Club (7640 Halstead)

Checkmate (at 55th and Calumet)

The Place (619 east 63rd ), where the Mustangs resided High Chaparral (7740 Stoney Island and busses 63-77)

Blue Flame (809 E. Oakwood)

Packin’ Room (71st east of Jeffery)

On the West side, which is a rougher part of Chicago: Mama Blues, Papa Blues, Silvios, Cheetah (4800 N. 900 W), Mr Fox.

One of One-derful!'s talent scouts, a man of circa 35 years, checked the list and made a couple of additions.

But when Eddie and George discussed whether there were any 
good shows in town they settled with Sarah Vaughn. The week after there was an evening with Billy Eckstine that they mentioned.

Later I knocked on George's door. He didn't seem to have much to do these days. He appeared to have lost interest in the music business. But he remarked, without being patronizing that my own interest bordered on religion. Which also was a nice way to say that I was a fanatic.

His own family had been active in the music business since the early 1900s.

He knew a bit about Swedish Jazz, which he held in high esteem, and he mentioned baritone sax player Lars Gullin’s name.

George preferred the big picture rather than getting involved in the details. It was surprising that he'd rather talk about black music's place in society in general than about his time as an assistant to Lester Melrose for example. His favourite word in these discourses was "ethnic."

But I understood that he had known Big Maceo and nowadays his son. But he never talked about Little Walter and the other blues artists that he and his brother Ernie had recorded for Parkway in 1950.

He was quite frank when he talked about his own artists.

He seemed sincerely sorry to have lost Otis Clay. He felt that McKinley Mitchell was limited as a singer as he had no timing. 
“Wonder Boy?!”- I will never forget his distorted facial expression and his sad and sarcastic laughter when he mentioned his name. I could understand that Wonder Boy had not fulfilled the promise George had had. That the picture "Wonder Boy" had of himself was not materialized in real life. Perhaps his facial expression also meant that he felt that Tyrone was too selfcentered. It was evident that George felt that his stake on Davis had been wasted.

Still not long after this conversation Tyrone "Wonder Boy" Davis became a national sensation and the biggest soul star in Chicago on the Dakar label.

He had great expectations on The Sharpees ("I'm So Tired Of Being Lonely”). It was a very good vocal group that could have been the equals of the Temptations. But they fought among themselves and eventually he got tired of them.

He also felt that that Alvin Cash group should be named the Registers and not the Crawlers. George also talked about the promotional tours he had made to the south to sell their soul artists recordings.

Alvin Cash and McKinley had been contacted but they had not yet been at the office.

In the evening I went to the Bonanza Club which was located on 7640 So. Halstead. It was exciting to travel this way with the elevated train. It screeched its way on a wooden platform which from time to time felt unsteady. With every stop the number of black people increased. Imposing wooden apartment houses 
stood down yonder. They seemed to be created for musical house parties. I had a romantic view on life there. It must be a symphony of sensual pleasures with music, sex, liquor, drugs, gambling - every forbidden vice in fact. I daydreamed about it while the train slowly moved forward.

Outside the Bonanza a friendly guy introduced me to Pat. He said that he was working as a PR-man and talent scout for One-derful! records. (George didn’t confirm or deny Pat's claim afterwards. They obviously knew each other.)

Pat was something of a jack of all trades at the Bonanza but he was kept in a rather short leach by the club manager Mr Edward.

The club was owned by Rudy Howard. I asked Pat about McKinley Mitchell and Pat answered that he was at the High Chaparral and that he himself was going there later. I think the Bonanza was closed that night since the whole staff was going to High Chaparral. It was still daylight outside so I walked through pretty empty quarters. I always tried to look efficient and walk fast under those circumstances and not giving anyone the impulse to rob me. During third and fourth grade I had trained track running with classmate and later Olympic gold medal winner Anders Gärderud (1976; 3000 meter steeplechase) so I thought optimistically that I could run away from any perpetrator.

There was music coming out from the open windows. But most often it was Martin Luther King’s speech “I Have A Dream.”

Almost at my goal I walked through some rather disorderly 
business blocks. Suddenly a police car drove up by my side and I was asked what I was doing there. I tried to explain and the policeman said "Take a taxi, these are dangerous streets to walk around all alone.” I waited until the police car was out of sight and then continued on foot the last stretch of a highway-like road out to Stony Island Ave. It was dark outside now but the road was lit by good street lights.

At High Chaparral I was welcomed with open arms and a couple of free drinks. Pat introduced me to the Scott Brothers, Reggie Soul, James Bennett and Joan, Bonanza’s very attractive cocktail waitress.

Unfortunately, McKinley Mitchell was not there but I believe that Pat wanted me to get acquainted with the Scott Brothers, using McKinley as bait. The same thing happened again, especially in New Orleans. Manuel Arrington was the MC and comedian also this night and he introduced me from stage when the show was about to begin. I rose up and got a little sparse applause.

The Scott Brothers Orchestra were:

Howard Scott (bass and vocal), Walter Scott (guitar), John Jackson (tenor sax), Bill McFarland (trombone), George Robinson (trumpet), Ira Gates (drums).

Howard told me that the orchestra could be heard on such outstanding recordings as Otis Clay's “Don't Pass Me By” and Alvin Cash's “The Barracuda” and also their latest release. They had worked with Monk Higgins and can be heard on many of 
his productions and have accompanied Tyrone "Wonder Boy" Davis.

They had produced Reggie Soul's “My World Of Ecstasy” on Capri Records.

They were contracted to Mercury but planned to leave in a month when the contract expired.

In all there were ten brothers in the Scott family and all sing and play.

During this night's set with the Scott Brothers Revue Irene Scott sang Aretha Franklin's "Baby I Love You” and James Bennett did Wilson Pickett's “You're Looking Good” and James Brown's "I Got The Feeling.”

I also met the owner of High Chaparral who was dressed in a Hawaiian shirt and a shell necklace and his friend Thurman Cooper who was working at the local union - the Chicago Federation of Musicians. Pat gave me some addresses and tips about what to do. He also suggested that I should film the weekend show at the Bonanza. But I said that I could not afford it.

After the show I accompanied James Bennett and his girlfriend to the local train station. Both were very well behaved and sympathetic youngsters in my own age. James was waiting to record his first record on the Capri label with the Scott Brothers.

I never saw his name on a record label afterwards. (Unless 
he was for example managing LeJam Records in Jackson Mississippi.)

James was soft spoken and quiet and perhaps better suited to be behind the stage than a touring artist.

My budget didn't allow any taxi travel and I was often sitting at stations waiting for the morning train. There were no trains in the middle of the night. But the night air was cool and refreshing and I was so excited after these Chicago concerts that sleep was impossible anyway.

Thursday, June 20

In the morning I went to the local grocery store to buy food. Among products on a shelf lay a small pile of 45-records with the Upsetters on the Little Star label. Eddie Silvers had told me about his time with the group so I naturally bought one (Valley Of Tears / Freedom Ride). Later playing it, I was surprised to hear Little Richard singing on it.

I continued to call Willie Parker, but he never answered.

Pat had given me the address to WGRT (221 North La Salle, 5th floor) and also written the names of five disc jockeys. Eddie Morrison, Mr Vee, Daddo Daley, Bob or Mr Tucker and Lon Dyson, whose names I marked - perhaps after I met him.

Pat signed his introductory note with: "Tell them Pat from the Bonanza sent you.” 
The radio station WGRT was located on the fifth floor in a modern office building in the center of town.

Lyn Dyson was very welcoming, but surprised that I was so interested in the careers of obscure Chicago artists. He seemed both well educated and in good shape physically.

Outside the Bonanza this night, I bumped into the energetic and skinny leader of the Scott Brothers, Howard Scott. He brought me to a record shop nearby and borrowed the gramophone and played a couple of new records that he had produced. It was Fred Johnson's “Don't Leave Me” on Shi Lush. Which was a fine Johnny Sayles styled effort. Reggie Soul's My World Of Ecstacy (Capri 11712) was a more mediocre try in the pop soul genre. I was given copies of both records.

My stay in Chicago circled around the Bonanza, Checkmate and High Chaparral Clubs. In the middle were the Scott Brothers Orchestra. They had the reputation of being Chicago's top soul band. I think that this reputation was well deserved.

To me they represent the local soul band with large ambitions. They try hard to get a regional reputation and then win success on the national scene.

First and foremost it was about creating a solid stage show and engage good singers and instrumental soloists. And to enlarge the orchestra with more instruments and to launch the singers on their own record labels Shi Lush and Capri. And to work as studio musicians for other artists. And to write their own songs and get hit records. 
Howard Scott had written songs like "Got To Get Over” / "I Resign” / "Do You Know What Love Is” / "Teardrops for Syl Johnson” and “Ain’t That Good Enough” for Ira Gates. He had also produced “Ode To A Soul Man” and "I Take Those Skinny Legs” for Syl Johnson.

His Orchestra had appeared in all possible places in Chicago and accompanied Maurice and Mac, Johnny Sayles, Liz Lands, Syl Johnson, Otis Clay, Alvin Cash, Chi-Lites, Bobby Johns, Junior Wells, Garland Green, and others. His Orchestra was good enough to appear at the High Chaparral, Chicago's biggest soul club, even if it was on days when few people were out.

Tonight Johnny Sayles was going to appear at the Bonanza accompanied by the Scott Brothers Orchestra. The club was located on the corner of 76th Street and Halstead. From the entrance followed a rather wide corridor; where the toilets were, to a large square sized room for patrons. The stage was at the opposite side (to the left) as was the small dressing room. And to the right was the bar.

The club was usually half full and you could sit in the bar and talk without getting too disturbed.

The clubs in the USA were air-conditioned and well ventilated in contrast to English rock-clubs and Swedish very smoky cellar clubs.

The Bonanza club manager mostly stayed in his office. We didn't have much contact. But I got in free and got a free drink every now and then. 
I arrived early as usual and sat and talked with Pat when Joan asked me if I wanted to play a free record on the juke box. I chose my favourite "Looking For A Fox" with Clarence Carter, and without any hidden intentions whatsoever. But I noticed a young man sitting at the bar. He didn't look happy and he was Joan's boy friend!

I was saved from making any more mistakes by the arrival of Syl Johnson. His name had been repeatedly mentioned the last days, by for example Howard Scott. But I had not heard any of his records. I don't think any had been released in Europe so far.

Syl Johnson (6843 South Aberdeen) was born in Holly Springs, Mississippi in 1938 but his family soon moved to Memphis where he stayed until he was 12 years old. Then he came to the south side of Chicago and studied at Drake Grammar School and Wendell Phillips High School. He learned how to play guitar and in 1956 felt proficient enough to back musicians like Eddie Boyd, Muddy Waters, Junior Wells and others, on stage.

In 1958, while appearing with Junior Wells, he started singing. The next year he got a contract with Federal Records where he stayed for 6 years and recorded circa 10 sides/records. This included several fine songs like "Teardrops" / "I Got Love” / "Please, Please, Please” and my own favourite "I Resign.” There Syl delivers a perfect and very exciting tenor falsetto.

He started his own band, first only a four-man rhythm section which in 1965 had grown into a nine-piece band. They performed at The Club and other venues. 
Then he came to One-derful! Records and later to St. Lawrence, a Chess subsidiary, where he recorded "Do You Know What Love Is” / “Things Ain't Right” and “The Love I Found In You.” Then followed Twilight Records (later renamed Twinight) and his so far biggest hit "Sock It To Me" which became a million seller and immortalized this catch phrase. The follow up Different Strokes, another popular phrase, also did extremely well.

He toured all over USA and a couple of weeks later I met him in Memphis where he appeared at the Paradise Club.

Leroy Joyce, a friend of Johnny Sayles from the days when they were in the Five Du-Tones was also at the Bonanza. He lived at 1425 S. Trumbull (Ph: 762-0736). I continued my research and Leroy told me that the group which was formed in 1963 consisted of the following members: Johnny Sayles, Leroy Joyce, Willie Guest, Andrew Butler, Frank McCurrey. All took turns to sing lead. One-derful! gave them a contract and the first record was The Flee.

The next one Cool Bird launched the bird-dance. Leroy claimed that it was the first "bird" recording. Perhaps it was recorded before “The Bird Is The Word” by the Rivingtons which entered the charts at the same time. Leroy also said that he had the reputation of being the fastest bird dancer in the country. Their follow up "Shake a Tail Feather" entered the national charts in 1963 and has since become a classic.

In 1964 the Five Du-Tones toured Europe with the Harlem Globetrotters; a virtuoso basket ball team that featured gifted 
ball clowns. The group used to perform during the intermissions. The tour included the major cities in England, Germany and France. They also toured a lot in USA. But their follow ups sold poorly and in 1966 the group broke up and Johnny Sayles continued on his own.

Now, there were plans to start all over again because of the renewed interest in "Shake A Tail Feather," Leroy said.

At the time it was included in the Ike \& Tina Turner Revue and Ray Charles brought it back in the first Blues Brothers movie (1980). The Bird had also reached England and I was taught the basics there in the summer of 1963. Sometimes in a party mood late at night I might even try to demonstrate it to others, and now I was talking to the fastest Bird dancer in the world. Amazing!”

Musically, The Five Du Tones sounded like other great groups such as the Contours (Do You Love Me) and the Rivingtons (Papa Ooh Mau Mau).

The interview was almost finished when Leroy brought my attention to a short and perhaps even a little stout man with a fine pompadour and a briefcase in his hand who sat on a bar stool a short distance away. It was McKinley Mitchell or Mac, which his friends called him. I only had time to rush towards him, shake his hand and ask him not to leave when the Scott Brothers started playing.

Irene Scott sang her Aretha Franklin inspired set (“Ain’t No Way,” "Baby I Love You,” “After Loving You,” “Knock On Wood") - songs that I had previously heard with her. Then the 
Scott Brothers did Gotta Get A Groove while James Bennett did a couple of songs I hadn't heard him do before like: "In The Midnight Hour” (Wilson Pickett), “Open The Door To Your Heart" (Darrell Banks) and "Something Is Wrong With My Baby” (Sam \& Dave). On a couple of James Brown numbers he imitated the master's dance style.

This was a shortened version of the Scott Brother's Revue and now it was time for the head attraction Johnny Sayles.

Johnny Sayles was a superb singer. A truly great screamer who in fact even equaled the master of gospel-soul shouting Wilson Pickett himself. He really had the audience in his hand. I understood that he had a very good reputation in Chicago's south side soul clubs.

I have never before or later been in the proximity of so many truly great soul singers (The only exception was when I, the year before, entered the Stax Volt tour bus for autographs and got signatures from Otis Redding, Sam \& Dave and Eddie Floyd. Arthur Conley was on the outside. I saw him dancing and disappear round the corner of the Konserthuset ...)

Johnny Sayles invited Syl Johnson on stage and he delivered Sock It To Me. It was the first time I heard this fine number. In fact it was so good that he almost outshone Johnny Sayles. Johnny put his arms around Syl and filled in the refrain.

This was part of Sayles repertoire this night:

"Raise Your Hand” (Eddie Floyd), "You Keep Me Hanging On” (Joe Simon), “You're Looking Good” (Wilson Pickett), “Try A 
Little Tenderness” (Otis Redding). Plus “Lillie Mae,” his latest on Chess. The Scott Brothers were in top form too. The six members sounded almost as much as the ten-man orchestra led by Chuck-a-Luck Charles that had backed Sam \& Dave on their second visit to Stockholm in the fall of 1967.

Johnny Sayles was born in Dallas, Texas on February 9, 1937. Rather early the family moved to St. Louis. From his seventh year he sang with the Tranquil Baptist Choir. He sang with Ike Turner's Kings of Rhythm before Tina came in the picture. Since then he has toured and worked with Albert King, Freddie King, The Falcons (when they included Wilson Pickett and Eddie Floyd), Alvin Cash, Little Milton, the Fifth Dimension, Miles Davis etc. He also sang on "Shake A Tail Feather" with the Five Du Tones.

Shortly after he moved to Chicago. In 1964 he was the first artist on the newly formed Mar-V-Lus - "They created that label for me.” He recorded "Don't Turn Your Back On Me" and "Got You On My Mind.” In 1966 he came to St Lawrence, the Chess subsidiary, and in November 1966 recorded his greatest hit so far “Never Let Me Go.” Then followed Minit Records (1967) and "Deep Down In My Heart” and “Anything For You.” Then he came back to Chess with "I Can't Get Enough Of Your Love” and his latest “Lillie Mae.” Both were produced by Monk Higgins.

Johnny has toured all over USA and appeared at the leading theaters and Soul clubs. He came to Alaska in 1964. He was booked for six months, but had to stay in two years (1964-65) as the public didn't want to let him go. Then he was back 
in Chicago again. He was often booked together with Freddie King.

At the back of the Bonanza room, music business people occupied two tables. I talked to a couple of DJs working at small soul stations. There were also record company people playing in the mid or lower divisions, like Bill Tyson. Robert Taylor was affiliated with Al-Teen Records at 8208 Stony Island Ave. We talked about So Much Love that he had recorded on that label.

Buddy Scott was one of the ten brothers in the Scott family. He led the group Buddy Scott \& The Rib Tips which was the house band at the Pepper's Lounge. (I somehow misunderstood that he was a drummer with the band. I visited Pepper's lounge briefly and maybe he was sitting behind the drums then, but according to current info he played the guitar). He told me that Junior Wells appeared at Peppers occasionally. I was given promos of their latest record that also Bill Tyson was involved with.

One of the topics of conversation was that Little Willie John had recently died. He had been incarcerated at the Walla Walla prison after killing a man in a bar room brawl. He was only thirty years old. The people round the table were saddened. I understood that John was greatly admired by other singers. That he could handle any singing challenge. James Brown made a tribute LP to Willie - “A Few Nice Things.”

I only had one record by John in my collection, but before leaving USA I bought his original of "Fever." This song had been a big hit for Peggy Lee in Europe in the late 50s. With Willie John's passing perhaps the best black singer alongside 
Jackie Wilson was gone. Someone else remarked that Jackie Wilson had been shot by a jealous girlfriend. The bullet was still lodged close to his spine.

When I later discussed this evening with George Leaner he said that those small radio stations had such a weak signal that they could only be heard one block away...

I felt that it had been a very successful night. Artists started coming who obviously wanted to talk to me. That was a big surprise, and extremely flattering as I admired some of them tremendously.

McKinley promised to come to the One-derful! office the next day. I really wanted to talk more to him and take some pictures.

It was also evident that his career had hit the bottom then. He talked about illness and marital problems and bad luck in general. He was certainly not a tough guy. In fact he seemed quite soft and sensitive.

What did he have in his briefcase? I was never told but I think it must have been a record contract and that he wanted me to sign him.

Johnny Sayles seemed more carefree and to be able to handle most of life's problems.

Syl seemed more contemplative and reflected about his career. He was thirty years old and he felt that it was old in his profession as a soul singer. He had no illusions that his success 
would last forever. Despite his two successes in the last year he knew how fast the public forgets.

Johnny Sayles asked me if I wanted a lift to my hotel. He and a friend had gone by car from Gary, Indiana. This light blue coupé with an open top was not new or even last year's model. Syl's car, that he later drove to Memphis with, was better.

With his friend behind the wheel and Johnny in the front seat and me in the back seat I was soon back at my hotel while they continued to Gary. Johnny lived at 7557 So. Wentworth there and his Club, the M.C. Lounge, was at 1501 Adams. Johnny also handed me his phone number: 846-7164.

It had been a great night!

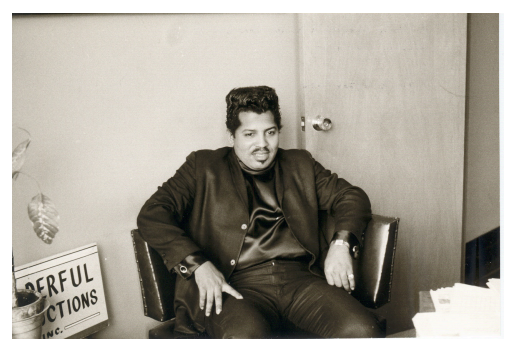

McKinley Mitchell

This is what McKinley Mitchell (9322 S. Emerald) said when we met at the Onederful! office.

He was born in Jackson, Mississippi on December 25, 1938. (George thought that the right date was more like 1933 while Wikipedia now gives 1934.) The family stayed there for $16-18$ years when they moved to Springfield, Massachusetts and in 1960 came to Chicago. He started to sing gospel in the early 1950s; first with the Hearts of Harmony and then with the Mitchellaires, from Philadelphia, PA. In New York (1956) this group recorded “This Old World Is 
Passing Away” with McKinley singing lead. In 1957 he crossed over to R\&B and started singing with the Tiny Button Quintet.

In 1958 he came to Chicago for the first time and started appearing in local clubs like the Cheetah. In 1961 he got a contract with One-Derful!. His first recording “The Town I Love In” became a major hit. Many minor hits followed and he mentioned “A Bit Of Soul," "It's Spring” ("the only song I have not written myself”, he said), “All Over Sudden,” "You're Never Gonna Break My Heart," "Darling That's What You Said,” "Watch Over me,” and "He’s Ready."

Monk Higgins arranged and produced his One-derful! recordings. In 1967 he recorded "Playboy" for Chess, but was now back on One-derful!.

He's married and has two daughters twelve and nine years old.

George Leaner said that McKinley for a while had been the top drawing local artist in Chicago. He used to be followed by a long tail of fans.

He had appeared on all the major R\&B theaters: Apollo, Regal, Uptown, Howard (Washington), Royal (Baltimore) and clubs like the Royal Peacock in Atlanta. And been on TV-shows hosted by Dick Clark, Jim Lounsbury and Lloyd Shafton. But right now his popularity had waned considerably. He was deeply disturbed over it, but seemed to lack strength to get back.

Today he would have received the clinical diagnosis of depression and received medical treatment with for example Prozac. He had a sinus(?) operation one and a half years ago and 
had not been able to sing for a long time. He was still troubled with headaches. It had forced him to cut performances short and walk off stage, and he had gotten the reputation of being a drug addict. The vibrato he used while singing had probably aggravated the sinus problem.

That's what he told me and I also understood that his marriage was in trouble. He felt misunderstood and there were constant battles at home. His wife seemed to have gotten tired of him. Maybe he had neglected her when he was on top.

McKinley was a first generation soul singer. He had a unique singing style, with a very heavy vibrato combined with a slightly vicious tone of voice. This was quite different from other soul singers like Wilson Pickett or James Brown who dominated the scene then.

Even politically he was out of touch. "Don't talk about Black Power - Give me Green Power instead!” he said, meaning green dollar bills.

The come back at One-derful! for this great soul singer never happened.

This night I went to the Checkmate, another leading soul club at 55th and Calumet. It was oblong in contrast to the square Bonanza. I think they could house a similar number of attendants. I also recall that the stage was in the middle but it's hard to tell now as the place was packed. In retrospect I think they had fuller houses at the Checkmate. Their manager was nice but had a rather cynical attitude towards the music 
business. I also met a strange man who said that he was a detective and talked much about black power and that he had special connections among the Black Panthers. But more likely, he was just a talkative alcoholic.

The comedian tonight was Manuel Arrington whom I had already had seen at the High Chaparral. Then he had portrayed a urinal scene and what can happen there with size comparisons and after-drip. Tonight he imitated Aretha Franklin and it was more fun. In the 1970s he often opened up for Tyrone Davis.

The mission of the comedian was also to present the artist and his show and give them a well deserved break and like a Master Of Ceremonies keep everything together.

The comical qualities in nightclubs were usually low. I never saw the next Lenny Bruce, Eddie Murphy, Redd Foxx or Moms Mabley. It was mostly simple sex jokes and perhaps some statements about racial relations.

The artists of the evening were Ruby Andrews and Garland Green and they were backed by the Exciters Orchestra, who were considered to be equal to the Scott Brothers. In the intermission I talked to both singers. First Garland said that he needed permission from his manager and that he was forbidden to talk. This was unusual. Otherwise all artists wanted to talk.

Ruby Andrews (5229 Greenwood Ave) was a very charming, kind and nice looking woman. She was born in the south side of Chicago on the March 12, 1947. She still lived there. (It is not uncommon that an artist forgets their roots. Ruby was in 
fact born in the (deep) south - in Mississippi before moving to Chicago.) First she sang solo in St John's Baptist Junior Choir. In 1960 she started singing R\&B and appeared at local school dances. She was popular enough to get a recording contract already in 1963 and she became a professional artist. But the company folded before any recordings were made (According to the discography there was one issue in 1965 under her birth name Ruby Stackhouse.) In 1967 she came in contact with Ric Williams and his Zodiac label (7447 Linder Ave, Skokie Ill.) which was distributed by Summit distributors. The first record Casanova in June 1967 became a big hit selling 25,000 copies per week before she stopped counting. Then followed "Hey Boy” / "I let Him Take Me” / “Kinda Love I Need” / “Just Loving You” (her latest.) All sold well enough, but not as much as Casanova. Ruby neatly texted these titles to make sure that they were spelled right in an article. She also recorded the fine “Just Don’t Believe It.”

She also wrote down three numbers she was going to sing tonight: Knock On Wood, Yours Until Tomorrow and Casanova.

Her songs are composed by the Brothers Of Soul who have had a hit of their own with I Guess That Don’t Make Me A Loser.

Ruby was still unmarried but she confided that it was going to change when she became rich. Did she tell the truth? From where came the Andrews name?

She had toured all over USA and also appeared in the theaters Apollo, Regal, Uptown, Howard etc. and been on TV-shows in Philadelphia and Cleveland. She was hoping to come to Europe 
soon. Right now she was appearing in all of the clubs in Chicago, usually backed by the Exciters. (Their solo guitarist was an albino. Rumours said there were two albinos in the group but I only saw one.) This six-man group took their name in Chicago in 1961, but they came from Washington (There is no connection with the Exciters vocal group that recorded "Do Wah Diddy Diddy.”) They used bongo drums on stage which was rather unusual then.

Ruby who had both a deep and large voice sang that night:

“Baby I Love You,” “Knock On Wood,” “Respect,” “I Heard It Through The Grapevine,” "Piece Of My Heart,” “Just Don't Believe It," "Your Until Tomorrow,” and of course “Casanova.”

It was a good show, but it was difficult to make any notes in a standing, rather packed crowd. I had never heard Ruby before on record but she made a sympathetic impression both on and off stage without belonging to the very top of her game. I don't think her "Casanova” had been released in Europe then.

The Exciters set consisted of numbers like "Tell Her I'm Not Home” (Chuck Jackson), "Respect” (Aretha Franklin) and "Try A Little Tenderness” (Otis Redding).

Garland Green was another new name for me. He was born in Mississippi in 1942 and came to Chicago in 1960. Down in the delta he had been influenced by blues and soul singers like BB King and Little Milton. They are still his favourites as is Chuck Jackson. He sang lead in the gospel group Leland Aires and started working at The Place. His latest record was "Girl I 
Love You" - a Jerry Butler inspired song. He recorded for Revue Records - a subsidiary for Universal. This night he sang songs like:

“Hold On I'm Coming” (Sam \& Dave), “Dock Of The Bay” (Otis Redding), “I Don’t Want To Cry” (Chuck Jackson), “A Man Needs A Woman,” which was sung in the best possible deep soul manner of James Carr. "If I Had A Hammer" had been transformed into a medley and included "Amen” and his hit "Girl I Love You."

Garland sang in a heavy, bluesy, deep soul style close to Otis Redding and James Carr.

Next year he had a massive hit with "Jealous Kind of Fella."

Upon leaving the Checkmate at closing time and following the stream of people I got next to a young man and his very pretty girlfriend. He was a little shorter than myself (I am $176 \mathrm{~cm}$ ). He looked at me for a while and then introduced himself as Alvin Cash. I had already gotten his phone number and we decided to get together as soon as possible. But this didn't happen unfortunately.

Saturday, June 22

I was invited to dinner at the Leaners. I think George's wife was a classically trained opera singer. They lived in a fairly large house in Chicago's south side with a nice garden in peaceful surroundings. There were both very nice neighbourhoods and run down slum districts in Chicago, almost side by side. After a fine meal, in fact the only hot meal I had in Chicago, because of 
my tight budget, the Leaner couple offered to drive me around to interesting parts of Chicago. I suggested the west parts where the riots had taken place.

Several blocks were burned down and areas as large as football fields were in ruins. There were several policemen in the streets - one was carrying a shotgun. But we cruised safely around in George's Cadillac. These types of neighbourhoods had not yet been shown in countless detective TV series to follow.

Later George confided in me that his wife had rather shown me the Opera House and other landmark buildings of Chicago. But he felt that it was good that I had seen the misery instead.

Leaving the Leaners I managed to take the wrong train twice and being late the Bonanza was full of people when I arrived. I guess there were about 250-300 people there. Artists appearing tonight were Maurice \& Mac, Liz Lands and The Jackson Five. I have forgotten the backing group as I came too late.

Liz Lands was very light skinned. She had a unique voice, a combination of Uma Sumac and Nancy Wilson with an enormous vocal range plus jazz and soul feeling. Tonight she did "Since I Lost My Baby" / "I Almost Lost My Mind” (Ivory Joe Hunter) / "Summertime" and also a couple of her own hits in a sophisticated soul style far from Aretha Franklin and Tina Turner but still appealing.

She was born in New York in 1938. She started singing in church as soon as she could walk. Already at five years of age she was a professional. In the early 1950s she had two gospel 78s out 
on the Mercury label: “Come In The Room” and "Somebody Bigger Than You” and I and continued her gospel career until she was nineteen years old.

In 1958 she married the comedian Tommy Brown who became her manager. He was the MC and comic at the Bonanza tonight. Newly wed they formed the T\&L label (= Tommy \& Liz) and she had hits like "Don't Shut Me Out” and "Let It Be Me.” They sold well all over the USA, said Liz. Flops were "Echo In The Back Ground” and "Keep Me.” Mercury later released a Liz Lands LP with jazzy songs that could be found in cut out LP shops in Stockholm. She had appeared all over America from Alaska to Florida and even in Bermuda. She had sung in Carnegie Hall and been a regular TV guest at for example Joe Bostic's show. She had recorded Midnight Johnny on Motown. She was also chosen for the B-side of "I Have A Dream (We Shall Overcome)” of Martin Luther King Jr's spoken record: on a Gordy 45. It was probably available in most African American homes.

Liz had many favourites like Jesse Belvin, Mel Carter, O.C. Smith and Billie Holiday, but she emphasized that she was not influenced by anyone.

While we were talking she wanted me to smell the glass of water ("no alcohol!") she was holding in her hand. Maybe she had been accused in the Negro Press of drinking too much?

She was a very good friend of Aretha Franklin and maybe there had been articles about her being Aretha's drinking companion during Aretha's marital problems? 
During intermissions Tommy Brown walked around and sold Liz T\&L records and his own comedy album.

I had already seen Maurice and Mac at the Regal eight days before. Now they did three Sam and Dave numbers in a row:

"Hold On I'm Coming," "I Thank You” and "When Something Is Wrong With My Baby.”

And Aretha’s “Baby I Love You.”

And last but not least their own current hit recording of Billy Young’s "You Left The Water Running."

Maurice and Mac were quite good but it was a bit disappointing to hear them do so many Sam and Dave songs and see them being so influenced by them in their stage act too. But in American soul clubs it was the current hits by the stars that mattered. So at best an artist could do their current recording and their old hits. But then they had to rely on other people's material.

Maurice was Maurice MacAllister and he was born on April 23, 1937. Mac was Green MacLauren. He was born in the deep south on the January 11, 1940 and moved to Chicago four years later.

They had met as children twenty years ago when Mac was eight years old - first in the Mount Calvary Youth Choir that had recorded Since My Heart Has Been Changed on Savoy. Maurice also had spent time in The Greatest Harvest Church Choir. (He might be on their recording of Steal Away, a Negro spiritual.) 
In 1960 they formed the group the Radiants with Wallace Sampson, Elzie Butler and Jerome Brooks. In 1962 they got a contract with Chess Records. Their first release Father Knows Best, which sounds like early Miracles, sold well. Then followed three more 45s including Shy Guy before Mac was drafted into the army. At the same time Elzie and Jerome departed the group. Maurice McAllister and Wallace was left and together with Leonard Caster they formed the "new" Radiants and recorded their biggest hit, the great Impressions inspired Voice Your Choice, one of the best ever soul group pop songs outside the Motown sphere.

Caster was in fact Leonard Caston Jr. and he was the son of Baby Doo Caston Sr. who played piano and sang in the Big Three Trio with Willie Dixon in the 1940s. In 1966 Mac was free again and he and Maurice quickly formed the duo and got a contract with Chess. The company had had limited success with another duo before; The Knight Brothers. Maurice and Mac's first record was So Much Love that Ben E. King had recorded earlier and then followed You Left The Water Running. The follow up Why Don't You Try Me was already released (Maurice called the song “Try Me Tonight”). Rick Hall produced them in Muscle Shoals.

They had been touring outside of Chicago and even in the southern states. Mac said that Maurice was his foremost musical inspiration. Both stated that the Radiants were inspired by the Impressions. But right now it was all about Sam \& Dave and apart from the three Sam \& Dave songs they sang tonight, they also did "You Don’t Know Like I Know." 
I interviewed all artists in the dressing room and not in the bar as before, as it was too crowded outside. First I was talking to Mac and then Maurice entered the room and took over.

While standing with my back towards the door a crowd of youngsters had entered. They sat at the short end of the room on a bench and stayed there while I was talking to Liz Lands and M\&M, with my back to the boys.

This group had made quite an impression before. Their act mostly consisted of James Brown numbers and their lead singer did every James Brown move to perfection.

Among the songs they did were:

"I Got The Feeling” (James Brown), "Security" (Otis Redding). “Tobacco Road.”

I think that they also did a Temptations number - probably "My Girl.”

The Eddie Silvers' composition "Big Boy" closed the show. Michael was incredibly apt in imitating James Brown.

I guess the Bonanza and other nightclubs had an age limit of 18 or 21 years to enter. The young and single women going to the clubs were of my age but many had one or two young kids at home. Very few had traveled around or even left their home town except to visit relatives. University studies were not common. Our lives didn't have much in common and there was plenty of room for misunderstandings. 
The young women, who made up the largest portion of the crowd, went crazy seeing Michael and rushed to the stage. He looked like six years old. My first conclusion was that the group reminded them of their children at home and they started missing them after a few drinks.

But afterwards, I also realized that they were far more experienced and had seen many more groups to compare with than I. They saw immediately that this was not an ordinary boy band but a future superstar. Because it was the only time this summer I saw anybody rushing to the stage and threw coins or dollar bills at the performers or the lead singer.

My only boy-band comparison was Donny Osmond and the Osmond Brothers that I had seen on the Andy Williams TVshow.

In retrospect I also wonder what had happened if I had rented that film camera and been the first to film a performance with the Jackson Five? Maybe I hadn't even filmed them and concentrated completely on Maurice and Mac and Liz Lands. Because I didn't interview any members of the Jackson Five. Their career was too short. What can you ask a baby like Michael? What his favourite games and sweets were? I do recall that an older man entered the room briefly. It must have been Joseph, their father. No introductions were made. But he's the one I should have interviewed, of course. I remember that he looked at me rather sharply when he entered.

The disappointment of the evening was McKinley Mitchell. He was recognized from stage and invited to sing. He did “A 
Cottage For Sale.” Perhaps as a tribute to Little Willie John, who had recorded it, and to Billy Eckstine who was appearing elsewhere in Chicago that weekend. But McKinley's lack of timing really ruined this song. His voice was not suited to jazzy ballads. I really hoped to see him do something more suited to his style.

We were mingling in the back of the Bonanza room and McKinley introduced me to soul blues singer Little Oscar. In the crowd around us was a leopard clad women in a very short skirt who knew Oscar and pronounced Oscar's name like "Ozzkar” in a very sexy way.

Sunday, June 23

Every year many churches had a special program and invited gospel artists and groups to perform. It was this type of church concert I was looking for. Posters were advertising the event and outside visitors were welcome. A regular church service seemed more private and it was difficult to find out if they had any gospel artists there.

I really didn't know what type of church I was looking for. Above the entrance there were words like Baptist - Church of God in Christ - Pentecostal - Holiness Temple - Methodist etc. I had no idea where the best music was and I never met or asked a gospel DJ for information and help. There was at least one gospel DJ at every soul station and there were a lot of gospel played there in the mornings (and sometimes in the afternoon).

On the Swedish radio in the 1950s Professor Johnson \& his 
Gospel Singers recording of "(Gimme That) Old Time Religion” was heard often. It must have been a strong European seller. Later in the 1950s Mahalia Jackson was also featured. In fact a couple of her records were in the family's record collection. And when Vee Jay became bankrupt their LP catalogue found its way to Sweden. I bought one with the Swan Silvertones. I had also bought James Cleveland's album "Peace Be Still” and last but not least an album with Archie Brownlee and the Blind Boys of Mississippi. But I knew very little about gospel music.

This Sunday afternoon I visited the Evening Star Baptist Church at 4235 Cottage Groove. I think I saw the poster in the record shop me and Howard Scott visited, or in the street nearby. The show started at 3:30 in the afternoon and I arrived in good time. In the door was an old man with a can of Coca Cola in his hand. He welcomed me with "Were you not walking in these quarters about a week ago?” His voice sounded like Leadbelly's. He was the priest there and after a short sermon he went around and encouraged and inspired the gospel groups with an Amen! every once in a while, with tears streaming down his face.

I was the only white person there. I sat down to the left in the middle of the church which had a capacity of perhaps 300 persons and now was half full. I was discreet and didn't take any notes. Now, I only remember Harmonizing Four's name from the poster.

First there were two fine male groups with circa five members each and a guitarist. 
Then came a group with older members (in their early forties). I think it was the Harmonizing Four. The lead singer had lost a couple of front teeth in the upper jaw. The climax came when he led the members in a church walk down the aisle. They were walking in a line singing "When the gates of heaven are open I'll come walking!” and made dramatic gestures and fell on their knees while singing. They sang without microphones and the guitarist was still on stage (I guess his cord was not long enough to follow). But it was no problem to hear them as I sat only a few feet away. The atmosphere was very intense and people fell out screaming in the pews. And I guess I was not far from fainting myself.

In Sweden the Bureau of Health would have stopped the show long ago. It was simply too exciting and maybe even dangerous for faint heart and nervous systems. Here a nurse just fanned people bringing them a little breath of fresh, cold air.

Next group was led by a very handsome young man whose intensity had a great effect on the younger women. And after him a light skinned male leading a six-member group. He was sweating and screaming. A couple of women were shaking and screaming in the benches and the singer also came in ecstasy. Singing, screaming, preaching and speaking with tongues he continued for at least fifteen minutes. A man nearby lay fainted for several minutes. They had overdrawn the allotted time schedule. But he continued encouraged by the old priest. Finally the guitarist and drummer started packing up their instruments...

It was difficult to get gospel singers to stop singing when the holy spirit hit them. 
Last was a female group and they also managed to electrify the audience.

It had been an extremely intense afternoon. My nervous system was overloaded. I could not go to a soul club that night, or visit the theater in the center of Chicago that had advertised "An evening with Billy Eckstine.” Or to the Regal Theatre that had a new program this week. At the bus stop near the church a female churchgoer in my own age asked me if I had enjoyed the service. I could only answer "yes" and then we took the same bus from there.

The two gospel concerts this week had given me food for thought. I had my eight grade scale for concerts and recorded music. Now I had to add nine and ten for a concert from where I was carried out unconscious because it was simply too exciting.

The African American music experience is not focused on youth and high strung and emotionally impressionable teenagers who scream and faint when they see their idols.

This was ordinary middle aged people of both sexes who might have tough working and social conditions. They didn't use drugs or alcohol. Once a week they recharged the batteries in church. They called it the Holy Ghost/Spirit and we in the west talked about delusion and self hypnosis. But this type of experiences and background had brought forward some of the most exciting artists in the world. (Archie Brownlee, James Brown, Tina Turner and many others; perhaps even Elmore James.)

Monday, June 24 
In the afternoon I went to 1507 S. Michigan Ave - The address of All State Distributors and their boss Howard Bedno. I had been given the address by Syl Johnson and All State carried some small labels like Twinight. But it was closed.

I continued walking happily unknowing that Bedno had been a partner in Cobra Records with Eli Toscano.

In the evening I went to Pepper's Lounge (503 East 43rd) which lay circa 30 minutes walk from the Bonanza. It was around 7:30 in the evening. There were many prostitutes and other (questionable) people in the streets here. It was rough. The door to the club was open and I looked in. I saw a low platform for the musicians at the other end. The room was smaller than the other clubs I had visited. Buddy Scott was standing next to the stage. A few nights ago he had given me his latest single with Buddy Scott \& The Rib Tips.

This was Junior Wells' home stage. His James Brown inspired recording of "Up In Heah" had been released in Sweden with a picture cover. I liked that recording. His Blue Rock recording of “You're Tuff Enough” was probably selling well then too. Junior and his longtime friend Buddy Guy had made youthful impressions at the 1965-1966 American Folk Blues Festivals.

Junior was not due to appear tonight so I continued to the Bonanza and their Blue Monday night. Little Oscar had given me a little leaflet about the event and said that this was the only gig of importance that he's had for months.

Oscar sat in the bar and we "reconnected." 
Little Nolan started the proceedings and sang backed by the King Edwards band: “Keep Me Hanging On.”

Next was either "Say Thank You” (Joe Tex) or "I Thank You” (Sam \& Dave).

An unknown song was probably called Egg and/or the Hen.

He was pretty good. He was dressed in a JB Lenoir like outfit tiger striped or leopard-like...

There was never time for an interview. (I have since been told that he and King Edward are brothers and that he played bass with Lonnie Brooks.)

McKinley was here again. He was going to make an unannounced performance. He asked me if there were any special songs I'd like to hear and I mentioned my favourites from his English President LP. "No problem” he said. "But I have not performed "I Found An Angel” for years and I know that King Edward can’t play it.” "I Found An Angel” is perhaps more like a pop R\&B tune than a soul ballad. But it's great nevertheless.

I don't know if he could read my mind but he must have understood that I was not impressed with his performance of "A Cottage For Sale” last week. Now he was going to set things right.

But first it was time for the fine guitarist King Edward and his orchestra backing Little Oscar, who did a couple of BB King numbers and then his fantastic soul blues Suicide Blues and his 
latest recording which was not near as good. Oscar was a good artist but his performance faded in comparison with what was to come.

Little Oscar Strickland (628 East 39th St) was born in Carol, Illinois in 1937. The family moved to Chicago but then back to (Greenwood) Mississippi in 1947 where they visited and stayed with relatives. Then they traveled via St. Louis until they finally were back in Chicago in 1951. Growing up he alternated between gospel and R\&B. But in 1954 he stopped singing gospel and started working in the Chicago clubs. It was a slow start and it took him 13 years to get a local hit with "Suicide Blues” / "Empty Bottles" on Palos Records which was leased and distributed by the Leaner Brothers. The recorded version was one class better than his stage version was that night. It's a first class soul blues - a knockout song, really. Now he was waiting for his second record (produced by Double H) "Two Foot Drag” / "Got To Make A Change” on Toddlin Town to be released on the 28th of June.

Oscar showed me his recording contract to prove that he was telling the truth.

While Oscar was singing McKinley disappeared to change clothes.

In the intermission I interviewed King Edward (or King Edwards as I called him then).

He was very dark skinned and born in Rayner, Louisiana in 1937. In 1955 he started backing traveling musicians like Big 
Joe Turner, Roscoe Gordon, Clifton Chenier, Jimmy Wilson and Freddy King. In 1959 he moved to Seattle and in 1962 to Chicago. He had been guitarist in Bobby Bland's road band. In Chicago he had been a studio musician for One-derful! and also accompanied McKinley Mitchell, Otis Clay, Little Oscar and Tyrone "Wonder Boy" Davis. His latest record was "A Change Is Gonna Come” / “Knock On Wood” on the Discount label, a Bill Tyson company.

On stage Edward did fine instrumental versions of Willie Mitchell's big hit "Soul Serenade" and his latest record "A Change Is Gonna Come” (Sam Cooke) and "Knock On Wood" (Eddie Floyd). When Edward heard that I was on my way to Memphis he recommended a visit to the Blue Velvet Club and Handy on Beale Street with its seventeen-piece band.

Then McKinley entered the stage. He stood still during his performance. The only thing moving was one hand keeping the beat against his trousers. He was pumping out one great song after the other. His voice was perfect. There was no doubt who had been the king of the Chicago Clubs and in my opinion he still was.

In the middle of the performance a strange older women came into the room. She was dressed in tails and a bowler hat and had a cane that she pointed towards McKinley from time to time. I thought that she was part of the Blue Monday show but she was probably only a confused fan of McKinley.

It was a small crowd at the Bonanza tonight, no more than 50 people including staff, orchestra and vocalists. 
According to my notes, McKinley sang:

“Evil Woman” (blues), “You Know I’ve Tried,” “Let Me Love You Again,” “Along The Navaho Trail,” “A Cottage For Sale” (which also tonight was his weakest number), “A Bit Of Soul," "I’ve Been Wrong So Long” (Bobby Bland) plus also longer or shorter versions of songs from the A-side of his President LP (UK) during his hour long set:

“The Town I Live In,” “All Of A Sudden,” “Darling That's What You Said,” “Hand Full Of Sorrows,” “A Bit Of Soul,” “Tell It Like It Is," "It’s Spring.” He also did "Running To The End Of The Rainbow” which I didn't then recognize but which must have been an early version of his later hit recording "The End of A Rainbow” on the Chimneyville/Malaco label some ten years later.

An extremely satisfying night and an 8+ concert and the best I had seen in Chicago along with Johnny Sayles and "Harmonizing Four."

Only a few months ago I had been sitting in my small one-room student apartment and listened to this album. Now the record had been exchanged to a live artist who was kind enough to sing my favourite songs.

There were very few people in the audience and he turned towards me all the time. It was like he was appearing in my small flat. He had a fine soul blues band behind him that were capable of recreating the hard soul sound that characterized Chicago not streamlined and slick but very emotionally satisfying. 
McKinley once said that he thought he could measure up to Bobby Bland - I could only agree. He belongs to the top ten soul male singers and can be compared to Otis Redding, James Carr or OV Wright. He is one of the really great unknown soul singers like Geater Davis or Lee Moses.

Tuesday, June 25

I went to George Leaner to say goodbye and thank him and tell him about my latest experiences in Chicago. We walked around in the building and ended up in the bottom floor where his brother Ernie and United Record Distributors was. There was also a young relative to George (or Ernie) who sat and listened to Alvin Cash on a tape recorder. It didn't sound that special. It was the same James Brown funky beat that everybody had at the time.

(It might have been "Keep On Dancing” or its follow up on Ernie and his son Tony's new record company Toddlin' Town. Scott Brothers were the backing group.) It was strange that Tony (?) was sitting in a closet in the United Distributors warehouse and not in the empty One-derful! studios upstairs. Was there a rift between the brothers; or was George fed up with this type of soul music?

I had not met Ernie or been in his warehouse before. He seemed to be more of an aggressive music business executive that the quieter, peaceful, philosophical and sometimes ironic George. But I guess the brothers were different - as in most families.

The lead singer of the Redemption Harmonizers dropped by to 
pick up a few promotional copies of their latest 45 on the Halo label, One-derful!'s gospel subsidiary. He autographed a copy for me. "He’s a good singer," George confided. "I'm trying to talk him into recording soul material in the future.”

Ernie followed George upstairs and there the two brother wrote me a list of important record business personalities I must meet on my round trip this summer.

Later Ed Cook, a well known radio DJ and personality from WVON dropped by. An animated discussion about opportunities for black people followed. Ed also promised to do a portrait about the brothers in the local Afro-American newspaper The Chicago Defender.

The discussion drifted into the Curtom Agency (8541 S. Stoney Island Blvd; near the High Chaparral) owned by Curtis Mayfield and Eddie Thomas - the manager of Curtis Mayfield and the Impressions. With veneration they said that Eddie Thomas' father was none other than Big Maceo himself. (He recorded the classic Boogie Woogie “Chicago Breakdown” in 1945.)

George Leaner had a good reputation in Chicago. Otis Clay said that he looked up to him like a father. I was lucky to have met him!

Then I went to the Checkmate again. Holly Maxwell was appearing tonight. She was the beautiful woman with a blond Afro hair style who had been among the crowd at the Checkmate last Friday.

Holly Maxwell was born on the October 17, 1945 (Sorry, I 
never dared to ask for a phone number or address). She started studying classical music at the age of nine. And got the education to be a piano teacher and also sang opera. She (graduated) finished this schooling and had appeared in a couple of operas with an all black cast. But on the September 18, 1963 she quit the classical music. She was afraid to lose her slim figure and become fat like other classical singers she had seen.

If Ruby Andrews seemed like the girl next door, Holly did everything to make an impression. Looks were important. She was married to her hairdresser and he had made her white wig. Her mother was a dress designer and both made Holly look good or even sensational on stage.

"I always try to be friendly, but still keep a distance to the public,” she said. Probably quite necessary with her good looks.

Not until 1963 had she started listening to R\&B and gospel. Soul was her kind of music now.

In 1965 Constellation contracted her and she recorded “(Happiness Will Cost You) One Thin Dime” / “Only When You're Lonely." When Constellation folded she moved to Golden World (1966) where she had her greatest hit Philly Barracuda and later she recorded “Don’t Say You Love Me Until You Do.”

But Golden World also folded.

Holly also wrote songs but don't feel they suit her style. Recently she had met a very famous German violinist who was so impressed with her singing that he wanted to work with her. 
This have already been told in the tabloid press, said Holly, but she didn’t want to tell me his name.

Tonight she sang the following songs backed by her regular group The Jaguars:

"Yesterday, Love Slips Away,” “Since I fell For You,” “Ain’t No Way,” “On A Clear Day,” “Misty,” “Goin’ Out Of My Head,” “Ode To Billy Joe," "What Now My Love” (where she also added a few lines from the French original "Et Maintenant”).

I must say that Holly brought life to these rather worn-out songs. It was a bit surprising that an ex-opera singer could put so much soul into what she did. Her best performances were Aretha's “Ain't No Way" and "Baby Baby Baby". She was nice and in fact a good singer even if she spent so much time on her good looks.

Holly also recommended that I contact Howard Bedno (All State Distributors) who took part in her career.

When I later heard some of the records she had cut around this time I think she only rarely succeeds. I think her strength is her stage performance.

While Holly was a new name to me I had heard about Lonnie Brooks (4633 S. Drexel) before. He was in the audience, and a nice young man who seemed fit and alert.

He was born in Louisiana in 1943 and moved to Port Arthur, Texas circa 1953 and to Chicago in 1956-7. Early on he started 
singing and playing the guitar. He got the nickname Guitar Junior.

He had never sung in church, but had backed artists like Jimmy Reed, BB King, Junior Wells, Otis Clay (1965), and McKinley Mitchell. In fact he had sat in on most Chicago blues and R\&B stars performances.

His first recordings were on Goldband in 1958-59 and he had a huge hit with Family Rules that sold 1/2 million copies. Even The Crawl / Now You Know sold well. In 1960-62 he recorded for Mercury, still under the name Guitar Jr. All Of My Life / Through The Days and Through The Nights / Love Me Love Me / The Horse (not the Cliff Nobles’ hit).

Then he had a car accident and had to rest for a year. He did two more records for Mercury in circa 1964: “The Train” / "My Girl” / "Figure Head Woman.” In 1965 he came to All State distributors and their Pillow label where he recorded "My Girl" / "Figure Head Woman." "The Trai," from 1965, that he wrote, sold 200,000 copies. (Or was it the same Mercury Recordings that were re-released?)

In 1967 he came to Chess. "Let It All hang Out," that he recorded in November 1967, sold well. While "Good Soul Lovin'” on the Cherry label didn't sell. He might have recorded more, but this is what he remembered on his night off. He was in a good mood. He had lots of gigs and did well.

Wednesday, June 26

The airline ticket had burned a big hole in my pocket and budget. 
Simple mathematics had shown that eating out was impossible. Most clubs in Chicago had a $\$ 1$ fee at the door. Then followed the obligatory drink at $\$ 1$. If you couldn’t sip on it all night, one more drink was another dollar. My daily budget was $\$ 8.50$ and included hotel, local travel, food, drink and clubs. Taxi was not possible. It was bus, tube and train but mostly walking.

I always chose the cheapest room in the cheapest hotel. The food was bread and canned food with pork and beans or ham and tap water with plenty of chlorine, to it. It was OK as long I didn't have to sacrifice the soul-clubs and entertainment.

Next stop was Memphis.

Postscript

In April 1984 I got a letter from Robert Pruter, author of the book Chicago Soul. (This is a translation of my Swedish translation):

He wrote: "I know about your articles in the Blues \& Soul Magazine (1968). For some artists this was the first ever written about them and there were no other information available. I have always thought that it was great that someone as early as 1968 reported about Chicago artists like Syl Johnson, Johnny Sayles, Maurice \& Mac etc. You were a pioneer cutting out paths in the wilderness while I was a latter settler who asphalted those paths."

It was very kind of Robert to write like this. I have also realized that perhaps I was the only one who made this kind of field trip from town to town visiting clubs and talked to record business people. I have tried to write as much as possible about what I 
saw and experienced at the clubs that I still can remember and can find in my diary.

My stay in Chicago had been very pleasant. The weather was like in Stockholm during summer. It was warm enough during the days and the nights were refreshing. I cannot remember a single situation when I felt threatened. The war in Vietnam was distant. I only saw a one-legged visitor at the Bonanza who used to dance to the jukebox.

I avoided the west side and kept to the south side. The blocks around the Bonanza and Checkmate were pretty calm. Even if there were so many great artists in Chicago most seemed to lack faith in the future. Many were disappointed how their careers evolved. It was a big city but still only a local market. It was difficult to move on. If you were stuck in Chicago you had to work small clubs the rest of your life there.

Perhaps that is why my arrival was caused so much attention. Some artists like Little Oscar and McKinley Mitchell even brought their recording contracts just in case I was there to sign them...?

The record companies were in a crisis. The era of the pop soul artists like Major Lance, Jerry Butler, Gene Chandler, Dee Clark, Betty Everett was over. The hard soul companies like Onederful! were soon closing down and Chess sent their best soul artists, like Etta James, to Muscle Shoals, Alabama to record. My favourites among the more obscure Chess/Checker artists like Sonny Warner, Tony Clarke, Mitty Collier, James Phelps and Cash McCall didn’t make much noise. 
SOUL MUSIC ODYSSEY USA $1968 \cdot 85$

The biggest Chicago soul hit that summer must have been "Stay In My Corner” with The Dells. 


\section{Memphis}

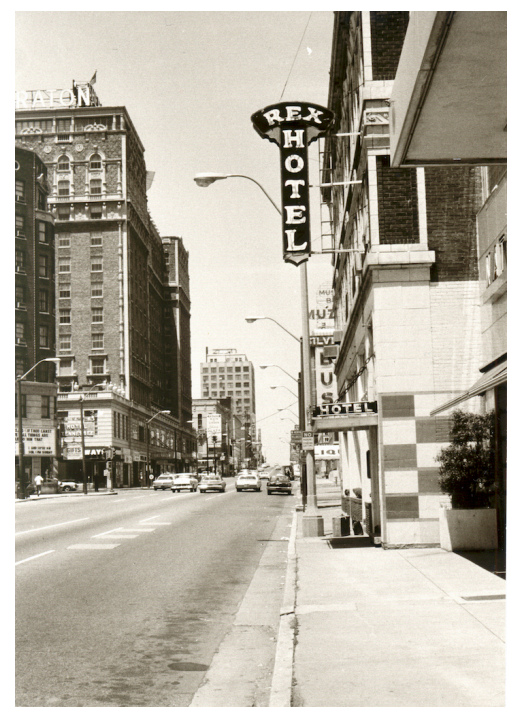

Hotel Rex, Memphis

June 26 - July 3, 1968

After a short flight from Chicago to Memphis I checked in at Hotel Rex which was located opposite the Greyhound Bus station. It was a third class hotel and the rate was $\$ 12$ per week.

By necessity, like other low budget travellers or local losers, I lodged in hotels waiting for renovation or bulldozers. I lived in these neglected city surroundings that summer. It became my home.

In the hotels the red carpets in the corridors were dirty and full of holes. Rooms were cleaned once weekly only, at best. Sheets were changed with long intervals and didn't always feel clean 
when you moved in. Sometimes there was a faint odour of urine and cockroaches.

It's like being in a B-movie when you are sitting on the bed in a T-shirt and your face is regularly lit up by a blinking neon sign across the street. At night you are often woken up by the fire brigade. An arsonist or squatter might have set fire to a building trying to speed up the renovation process.

Under the roof of the fairly large room at the Rex a fan circled slowly and kept the air dusty. Through a fly stained window was the view over an empty lot serving as parking space.

Segregation was no longer permitted but most African Americans still lived in the hotels in Beale Street. Even if the house walls had been cleaned you could still see remnants of the text "Colored Only" outside some hotels.

Still the Rex was better than the hotel I had lived in Chicago, and it was only a few blocks away from Beale Street. I went there immediately. It was far between the clubs and I could not discover anything of interest. The biggest action seemed to take place in the pawnshops and gun stores that lay in every block. Some houses had been damaged after the riots following $\mathrm{Dr}$ Martin Luther King Jr.’s assassination three months earlier.

I turned around and walked towards the business center with several skyscrapers of medium height. On the way I passed Hotel Peabody, a landmark hotel and one of the best in the south and well known for the big bands that played there during weekends. 
My budget didn’t allow any restaurant visits. So I bought food and brought it to the hotel and started my detective work.

When I arrived in USA I only had three addresses: The Apollo Theatre in New York, Chess Records in Chicago and Stax “The Home of Soul Music" - in Memphis at 926 E. McLemore.

The disc jockeys knew what was happening in clubs and recording studios. A visit to the leading station in every town was a must. WLOK was Memphis' biggest and the next day I walked there (300 South 2nd Street).

During the last year WLOK had gone from number ten to number one in the ratings. It was now the most influential Soul radio station in USA. It had been founded in 1956 and started playing $R \& B$ in 1959. The program director Al Perkins had a key position. He was the one who chose the records to be played on the air. Other DJs could play a song of their own choice,

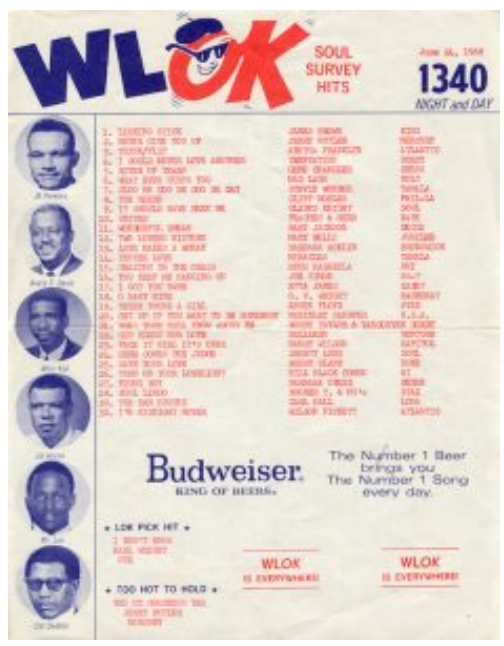
WLOK chart but $\mathrm{Al}$ had the last word.

He said that every week they got 500 single records from record companies all around USA (= 26,000 per year). This was before the LP-era and only about 20 LPs arrived every week. The station's play list consisted of 60 songs and five of those were 
exchanged every week. To listen through everything in detail would take 50 hours per week and instead they used the charts in Billboard and Cashbox giving info about what was played in other regions.

Bill Gavin's weekly newsletter "Radio Program Conference" judged the listening value of records. (Stax must have been depending on his benevolence as they dedicated a whole issue of their own news letter Stax Fax to celebrate Bill.) Later most stations had only forty songs on their play list and then some dropped to only twenty songs. The songs stayed shorter and shorter time on the list.

Every hour at WLOK was divided into five minutes of news and weather, eighteen minutes of commercials and thirty-seven minutes of music. They had around 200 different commercials and jingles to chose from. It was a soul music only station but with two exceptions: They also played the two bestselling pop/ rock tunes.

After a while Al told me that he had been a R\&B artists and it was icebreaking that I even knew a little about his biggest hit. I owned a copy of Otis Rush's "Homework” of which Al had done the original on USA Records.

It is not uncommon that a DJ had a recording contract. Sometimes it's a way for a record company to ensure the DJs loyalty towards the record company. Al had started as an artist so this was not the case.

He was born in Chicago in 1936 and was performing in the 
small clubs and made recordings between 1958 and 1962 on labels like USA and CJ. The songs he mentioned and probably also preferred were "Follow The Leader " / "You Left Me" / "Love Me Baby." Eventually I managed to buy nine of his different 45s. He performed with more well-known artists like Jerry Butler, The Impressions, Ted Taylor and The Temptations. He was also booked in the south.

When success eluded him he tried the radio business instead.

He enrolled in the radio school in Green, Mississippi and afterwards started DJ work at WOPE in Chicago, WIMI in Milwaukee, KALO in Little Rock and WLOK.

When we parted I got a lift with his colleagues $\mathrm{Mr}$ Vee and Cat Daddy-O who were also going to Stax.

The Radio station visits were to have a profound influence on my life. When I looked through the big pile of records that had reached WLOK in the last few days I immediately realized that I wanted at least $50 \%$ of those for my collection. I understood that the records that found their way to Europe or to the soul magazines review pages were only a very small tip of a larger iceberg. It really started a frantic record buying spree and finally I was sitting with a 32,000 record collection.

When I walked through the classic entrance of Stax Records I immediately experienced the famous southern hospitality. 


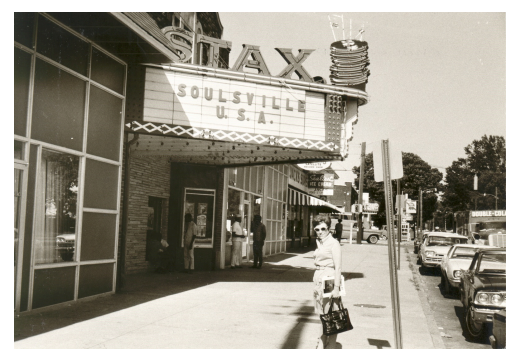

Estelle Axton

Estelle Axton, a very friendly woman in her late forties, invited me to a sightseeing tour the day after. She was one of the founders of Stax together with her brother Jim Stewart. The name was taken from two two first letters of their surnames. She also said that I was welcome at Stax whenever I wanted. This was not the case with Tamla Motown in Detroit. Despite much phoning and using the door bell I didn't even manage to get inside Motown. The door was locked for all outsiders.

I received a pack of free records and had to say no to some to avoid overweight at the plane. (Today some of those records could have paid for a large part of my trip and expenses.)

I was also introduced briefly to Steve Cropper, Jim Stewart and David Porter.

I asked what to do that night and they recommended seeing Roy Hamilton. Many years ago I had heard his "You Can Have Her” (1961) which is the original to a Swedish cover called "Sånt Är Livet” by Anita Lindblom. It's been one of the three top selling records in Sweden during the last century. (Selling more than a half million copies to a population of seven million people) 
With a map in my hand I took

a long walk passing several car dealers and industrial areas. Eventually I arrived to a large building in what might be called a suburb to Memphis. There was the club Top Four-um.

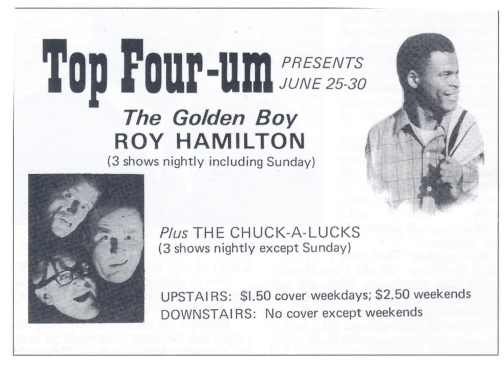

Roy Hamilton show flyer

Sitting down inside I was surprised to see that many patrons had brought their own liquor in brown bags and only ordered a glass and ice. If I remember right, the club could only serve beer.

It was also confusing to hear the first of three shows with Roy Hamilton that night. He only sang old standards like "Ebb Tide" and "I Believe" and had a tranquil trio backing him.

First after the break did I get a better perspective. Roy had been one of the foremost R\&B solo artists in the 1950s. He did sing popular songs but with a gospel feeling, just like Jackie Wilson. He belonged to the school of Roy Brown where Wilson and Clyde McPhatter are better known names today. I entered his dressing room and he welcomed me in a white-yellow turtle neck sweater. I asked him who the man just walking out was. It was Rufus Thomas, he confirmed.

Roy told me that he was born on the April 16, 1929. He started as a lead singer with the Searchlight Gospel Singers. When the group broke up in 1953 Roy started a solo career. Every Wednesday he tried his luck at the Apollo Amateur Night. (According to Jack Schiffman in Uptown: The Story Of Harlem's 
Apollo Theatre he was usually interrupted and run off stage as the judges thought he sang false.)

But his perseverance paid off and in 1953 he got a recording contract with Epic Records. He recorded Rodgers and Hammerstein's “You Never Walk Alone.” It became a major hit in 1954. This song which never won the approval of the Apollo audience now sold three million copies. (It is also the official song for the Liverpool Football Club; inspired by local group Gerry and The Pacemakers and their recording of it.) The follow ups did well too: "If I Loved You” (750,000 copies), "Ebb Tide” (1.5 million), “Hurt” (750,000), “I Believe” (750,000), "Unchained Melody" (1.5 million). It is not that common that artists can tell you the sales figures. Bobby Womack also knew how many copies his records had sold.

Roy got the nick name “The Golden Boy." He was one of the best paid black artists and his song style a model for other artists. He brought gospel feeling to popular music and paved the way for Sam Cooke, Brook Benton and Jackie Wilson and many others. He inspired Elvis too. He was very well liked by his fellow artists. Whenever in trouble they could always ask him for help as later testified by Joe Tex and the Dells. During the rock and roll era in the late 1950s sales were not as good as before but still impressive for these hits:

“Don’t Let Go” (1.5 million), “Without A Song," “I Need Your Lovin'," “Pledging My Love,” "You Can Have Her.” His "Everybody's Got A Home But Me" was mentioned in Jack Kerouac's book On The Road. 
Roy left Epic in circa 1961 and recorded for MGM and RCA. Then he left show business for the ministry. His farewell to show business had nothing of the drama of Little Richard. It didn't seem to have been a conflict between his faith and his choice of recorded material. He might even have preferred to spread his message among the gigantic crowds at an Alan Freed concert than in a church. After a few years he returned to music business and performed at middle class clubs like the one tonight. The guests here were circa $75 \%$ black and $25 \%$ white.

Roy had recorded an album called Rock and Soul, which was said to have launched that expression. Solomon Burke had been crowned the King Of Rock And Soul and frequently used that title. Was there any connection?

It is never wise to compare artists in an interview especially when it was obvious that I was a fan of Solomon but knew very little about Roy. But Roy didn’t mind that Solomon Burke used that expression.

Among his recordings in Memphis in later years is the Chips Moman produced At The Dark End Of The Street. Perhaps Roy's recording is the very best version of this soul classic. He also did a cover of Conway Twitty's “It's Only Make Believe.” Roy died of a heart attack in 1969 shortly after meeting Elvis in Chips Moman's American Sound Studios. Elvis is said to have been a great fan of Roy. (Roy was not a victim of the vices of show business but of a serious heart disease that finally ended his life.)

Sightseeing with Estelle Axton. 
On Friday, June 28th Estelle Axton picked me up. We were going sightseeing. She wanted to show me the interesting places in Memphis. Meanwhile she told me the story of Stax Records.

First stop was Poplar Tunes at 308 Poplar Avenue. This was the birthplace and present headquarter of Hi Records and one of the best record shops in the south.

The owner Joe Cuoghi said that he was born in the early 1920s and early on helped his father in the grocery store. In 1946 he had bought the Poplar Tunes record shop and had made it one of the leading in the south. A well-run record shop is often the starting point of a record label.

Just like Bobby's Records in Harlem, New York was the starting point of Bobby Robinson's Red Robin and Fire/Fury labels. Or like Excello/Nashboro started with Ernie's Records, and Dot from Randy's Records or Jewel/Paula/Ronn from Stan's Records. All had mail-order businesses too except Bobby Robinson. I used to buy from Randy's and Ernie's.

Joe didn't play any instrument but knew from the strategic location of his shop what people wanted. In 1957 he bought a prerecorded tape and released it on Hi Records, and his first big seller was Jay B. Loyd’s “I’ll Be Alright.”

Hi was most well-known for its fine instrumentals with Bill Black, Ace Cannon and Willie Mitchell. Their biggest vocal hits were Jerry Jaye’s “My Girl Josephine” and Gene Simmons' "Haunted House."

Next stop was the Sun Studio. It was not the old one at 706 
Union Avenue, by many considered the birthplace for the post war youth culture. Even if Elvis was the most talented artist of his generation, had he not been born, someone else sounding similar, but not as good, would have probably surfaced in another town and in another studio.

The studio at 639 Madison Ave (?) was newly built. Knox Phillips, son of Sam Phillips, was there and ran things. He told us that Sam Phillips had lost much of his passion for music and instead took care of his investments, in particular the motel chain Holiday Inn. Dickey Lee was there and recorded that day. A few years previously he had topped the charts in Sweden with "I Saw Linda Yesterday.”

Knox also said that a crazy Englishman was paying them a visit. It was Breathless Dan O’Coffey who spent his summer holidays going through the Sun warehouse looking for rare records.

Next Stop was Graceland. We stopped outside the gates with its two guitarists in forged iron. Elvis was in Hollywood making another film, and we were the only people outside. This was a pretty dark period for Elvis. His records sold poorly and his fans had tired of his films. His lifestyle was also out of phase. Living together with bunch of school and military friends renting cinemas and amusement parks for entertainment seemed shallow. At least in the year of student revolts in Europe and while hippies tried to find the meaning of life. A bit further up, the house could be seen between trees. It didn't look much out of the ordinary, I thought. I had seen better homes in upper middle class districts back home. 
Talking about Elvis and Graceland would not create any interest or be welcomed at home while the black ghettos and black music would interest many more.

Six days earlier I had seen Michael Jackson and the Jackson Five in Chicago. We had been sharing the same dressing room after their performance. I could have been the first person to tell Elvis that I had met his future son-in-law, later to be married to his unborn daughter Lisa Marie ...

Next stop were the Pepper Tanner studios. They were an important part of the media industry. Two hundred and fifty persons were working at the world's biggest company for making radio advertisements. They were active in all musical areas and with all types of radio stations. Soul, pop, C\&W, classical, gospel and jazz and rock. About 3700 of USA's 4500 radio stations were customers. They had six full-time writers and idea-developers.

The step between making radio commercials and records might not seem that great. They had formed Pepper Records with Marty Lacker as CEO. He was formerly Elvis's private secretary and bookkeeper. The idea was that radio stations buying their commercials would not hesitate to play their records too.

But it had failed. There were no hits. Maybe radio stations subconsciously were suspicious of music coming from a company making commercials? Or was Pepper too far ahead of their time, and a future with MTV and rock videos? The Pepper recordings I had heard had been fine, but they are not on the same high level as Stax (or Hi). 
During lunch and while driving Estelle had given me quite a lot of information about the non-assuming start of Stax. Deanie Parker, Stax PR woman added more later.

History of Stax

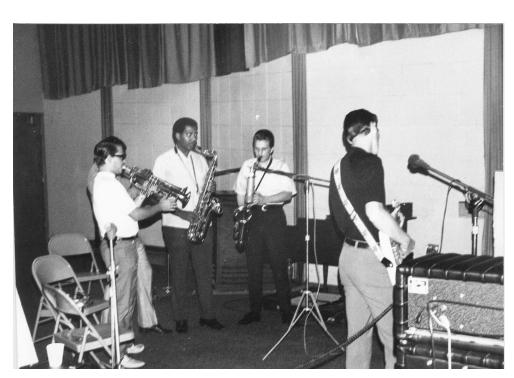

Stax recording session

Jim Stewart, Estelle's brother, was born in 1931 and when seventeen moved from Middleton, Tennessee to Memphis. He did not complete his university education but started working in a bank. During nights and weekends he played the fiddle in a C\&W band. In the intermissions it was not uncommon, said Estelle, that a persistent young man with a guitar wanted to enter the stage and sing. Of course, it was Elvis, and his later success cannot have left the musician or the bank man Jim Stewart untouched.

Jim met a disc jockey, Fred Bylar, who had a good voice. Together they went to the Sun studio for a test recording. It was 1956 and Elvis had left Sun. They wanted to fill that gap but both Sam and Jim thought that it sounded awful. Sam don't like the suggestion to hire Jim as a producer at Sun either.

Instead they went to a barber who had recording equipment and a decent tape recorder and made their record.

No company wanted to release it and they released it on their own label. No success, but they had now been bitten by the show 
business bug and rented a big garage just behind Jim's quarters and later a barn where they build a very primitive studio.

Soon Bylar was tired of this very expensive and time consuming hobby. Jim, \$10,000 poorer, asked his sister Estelle for help. She had opened a small record shop, Satellite Records, in the Memphis black ghetto. She was tired of being a housewife. She mortgaged the family home and used the money to buy a one channel Ampex tape recorder. Behind the counter in her record shop Estelle had noted the enormous demand for gospel based $\mathrm{R} \& \mathrm{~B}$ recordings. But the poor sound on her brother Jim's garage and barn recordings had scared away any prospective customers.

About the same time she and Jim heard that the Capitol cinema at 926 East McLemore was for sale. They rebuilt it into a studio and at the same time moved Satellite Records there.

The shop was still there but was closed shortly after my visit when the studio needed more space.

Jim hung up his fiddle in his office and he and Estelle added the first letters of their surnames - St and Ax - and the Capitol cinema was thereafter called Stax. In the middle of the black ghetto people wanted to hear R\&B. Jim didn't have to use his fiddle very often, except when his friend Rick Hall visited for a business talk and they played together.

Stax soon formed a subsidiary label called Volt with the same repertoire. While Enterprise, a jazz-pop-easy listening and blues label, came later. Every second soul record bought in Memphis had been recorded in the Stax studios. They had 50\% of the local 
Memphis market. The turnover was \$30 million per year and so far the company had three hits that had sold over a million each:

“Green Onions” (Booker T \& The MGs), “Soul Man” (Sam \& Dave), "Dock of The Bay” (Otis Redding).

In June 1968, 22 people worked at the Stax offices and there were 24 solo artists and groups contracted; and 32 distributors all over the USA handled their records. In 1968 they had signed many new artists: Jimmy Hughes, Judy Clay, Anita Lewis, Harvey Scales and the 7 Sounds, and the blue eyed soul singer Linda Lyndell. In 1965 Al Bell had taken over some of Jim’s responsibilities. He had owned the Detroit based Safice records, where Eddie Floyd recorded. He had brought Eddie to Stax. Al was now vice president of Stax which made him the highest ranked black person in a white owned company in the southern States. Stax annual reports had shown an increase in sales with $100-200 \%$ every year since the early 1960s. All prognosis pointed to continued success.

In the early 1950s the R\&B companies Aladdin, Atlantic, Peacock, Specialty and others, had an exclusive black audience first. When white listeners came sales doubled. The same thing had happened in soul music and Berry Gordy's Tamla Motown was the most profitable company in the USA (no matter size and type of business). In the spring of $1968 \mathrm{Jim}$ and Estelle sold the company to Gulf and Western, which also owned Paramount Pictures. The entertainment sector was only one percent of Gulf and Western's turnover.

Estelle also said that sales of soul music had increased rapidly. 
Before 1960 a hit record sold 300,000 at best. If it sold more the white "avant-garde" also bought it. In 1968 the upper limit of a soul hit was a couple of million in sales. In Europe Stax sales had doubled in the last year. Much because of the Stax-Volt Tour there in March-April of 1967.

The biggest markets were England and France while Germany was lagging behind.

Gulf and Western's new strategy for Stax was to quickly build up a LP catalogue. As many as 25 new LPs were released in the fall of 1968, thus immediately doubling the LP catalogue. The studio was busy round the clock. Even the producers, songwriters and the studio musicians made solo LPs to fill the quota.

But haste makes waste and the market was oversaturated with second rate soul LPs. Gigantic PR campaigns were launched. Their company newsletter Stax Fax was widely distributed. It also reached Sweden and me. Artistically I think it was a big mistake to sell to Gulf \& Western.

Still, Stax was lucky. Isaac Hayes, most well known as one of the songwriting and producing team Hayes-Porter had, after a slow start, an enormous success with the LP Hot Buttered Soul. I guess this record financed all the other 24 slower sellers. Isaac's new persona Black Moses was a huge hit among both black and white women.

I remember him (and his partner David Porter) as a two real nice guys running around the studio premises always busy and without any signs of egos or star complexes. 
While walking across the Stax parking lot Isaac arrived in a car with the four members of the Soul Children - due for a record session. Isaac welcomed me with big hug and a smile and then escorted them into the building.

On a clear and sunny day in April 1959 Rufus Thomas comes walking with his daughter Carla by his hand. He was a popular DJ at WDIA and recorded the hit Tiger Man at Sun Records in 1953. Carla was a very pretty teenager (16-17 years old) later called the Memphis Queen. When they saw the sign Recording Studio they jumped at it immediately.

Rufus had written songs and the duet, "Cause I Love You,” was the result of the contacts established this day. Jim couldn't afford to release it until after a year. Then it sold 15,000 copies in Memphis and its surroundings. This was more than any other of Jim's previous releases.

Atlantic took over distribution and Gee Whiz with Carla almost sold a million in 1961. Later came Rufus own "The Dog” and "Walking The Dog."

The Rolling Stones jumped on the Dog bandwagon with their first album too. Other milestones the first years were: "Green Onion” (Booker T \& The MGs), "Last Night” (The Mar-Keys) and "You Don’t Miss Your Water” with William Bell.

Hayes-Porter

Isaac started as a butcher's aid in a slaughterhouse. One night he was watching TV at home when the doorbell rang. Outside was David Porter selling life insurance policies. It didn’t take long 
for Isaac to turn off the TV and for David to change subject. They discovered that they had a lot in common. Both used to hang out in the Memphis clubs trying to get touring artists to listen to songs they had composed. They also didn't mind sitting in on stage whenever given a chance.

They decided to collaborate and together with a local DJ they started Genie Records. They had no major successes but got experience and in 1963-64 became affiliated with Stax. Their first assignment was to write and produce for Sam \& Dave.

\section{Deanie Parker}

The 23-year old head of the publicity department was born in Mississippi. In 1962 she was working in a record shop when winning a song contest which resulted in a recording contract with Stax. She recorded two records:

"Imaginary Guy" / "Until You Return” (Volt 105) and "Each Step I Take” / "Mary Lee Can Do The Bumble Bee.”

They didn't make much noise and in 1963 she started as a DJ at WLOK and worked as a secretary at Stax for a short while. Then she went to college and in 1965 hooked up with Stax again, this time as composer and PR-woman. She wrote the liner notes for the early albums of Otis Redding, Sam \& Dave and Eddie Floyd, sometimes under the name Deanie Catron. Perhaps she also added to their design.

Otis' two first albums showed his face, while the next two used female models instead. Probably because of misguided consideration for the white customers who had started buying 
his records - while the liner notes still paid attention to those who were not used to read. Large letters and an easy to understand language was used. Still not aware of that the intellectual youth in Europe and USA were the forthcoming buyers.

It was difficult to differentiate between a Booker T and the MGs album with only onions on the cover and a schlager potpourri album with Mantovani or James Last with a similar design. A racially integrated group was not possible to show then so you had to know that the number of white families naming their sons Booker were almost nonexistent.

Deanie also wrote songs like "Don't Mess With Cupid," "New Years Resolution,” "I’ve Got No Time To Lose” (one of Carla Thomas' best), and “Sleep Good Tonight.” When the Mad Lads recorded "I Want Someone" she played the piano.

\section{Club Paradise}

I was at the Club Paradise and watched a show with local talent. The orchestra was led by a young man who worked in the Stax mail room and handled the distribution of promotional records. Among the singers I especially remember Big Ella. A young café aut lait coloured woman who has recorded some pretty good records.

The show was typical of a soul show in 1968:

A six to seven piece band (trumpet, one or two saxophones, guitar, bass, drums and sometimes keyboard) had a repertoire usually consisting of $10-20 \%$ James Brown songs and 10-20\% 
of Aretha Franklin numbers, depending on the number of male or female vocalists. Then there were $10-20 \%$ Memphis hits and one or two of the Tamla Motown best sellers. Usually they also featured the biggest instrumental hit of that summer - Cliff Nobles recording of "The Horse.”

Other songs that were heard everywhere that summer was "Funky Broadway” (Dyke and the Blazers/Wilson Pickett). Plus “Here Comes The Judge” (Shorty Long's version of Pigmeat Markham's original comedy recording). Regular instrumental numbers were the 1968 hits "Soul Serenade" (Willie Mitchell) and "Grazing In The Grass” (Hugh Masekela).

I was invited to a table with two white girls and a black man. One girl seemed interested in the black man while my job was to take care of her friend. After the show, the man invited us to his home. "His" girlfriend drove us there in a small Volkswagen "bubble." He lived pretty close to the Stax studio. We were served drinks and he demonstrated his water bed and other gadgets at home. My companion didn't drink. She came from a strict religious family that didn't even have curtains at home. She felt quite lost at a black soul club. While her friend had been completely changed after watching James Brown at TV. She wanted to go to those places all the time. The couple seemed to want to be undisturbed so me and "my" girlfriend sat outside on the staircase and talked. After a while her friend rushed out with disheveled clothes but she was persuaded to go inside again. When she came out next time she was sad and told us that she had been raped. And we left.

It was a strange evening. And so were race relations in the South. 
Why did she re-enter the house? Why didn't she leave or call on us?

Memphis was not a great entertainment city in comparison to Chicago. Most of the activity centered round the recording studios. The local artists that had a hit were catapulted to the national scene. While the studio musicians could be seen at special events like a DJ's birthday party or at best toured and performed during weekends locally or near Memphis. In Chicago artists had plenty of work almost every day of the week at a multitude of small clubs to choose from while Beale Street seemed dead during the weekdays.

I had received so few advices and tips about soul events that weekend that I simply started asking passers by on Beale Street what to do. This Saturday it was definitely the concert at the Mid-South Coliseum, an indoor stadium housing circa 8-10,000 people.

Al Perkins was the M.C. and among the artists were Joe Tex, Rufus Thomas, Carla Thomas, The Bar-Kays, The Delfonics, Paul Kelly, and Donald Height. A couple of gospel groups opened the show. Like The Spirit Of Memphis, where soul singer Joe Hinton had started his career.

I sat fairly far away from the stage and these years the sound systems were not really up to filling a large arena.

After the concert while standing in the bus line my concert program was snatched away from my back pocket by a black man of my own age. It had cost one dollar, but more important I 
had made notes about all performers and songs. It was probably an advantage to belong to the white minority in situations like this. It was evident that I had not started the argument. I was not that rich either as I waited for the bus. At these occasions black people usually came to the rescue, but I was not able to get the program back. The following reconstruction is not 100 \% complete. (But the lineup I saw is definitely different from "WDIA’s Starlight Revue” found on the internet)

"Pigmeat" Markham did his major hit monologue of 1968, “Here Comes The Judge,” with musical accompaniment. (It was not called rap music then, but today it would certainly be.) There were three persons on stage including one woman. "Pigmeat" (1904-1981) wore a hat and was dressed like a bum. He was one of the top male black comedians in USA.

His choice of the name "Pigmeat" indicates a great portion of self-irony, and freedom from ego and pride. It is far from the Black Panther slogan of black pride. I guess most black people laughed at the jokes, but also that white people didn't understand that "Pigmeat" mocked us too while fitting in the Ku Klux Klan stereotype of the black person as a complete loser and a useless citizen. It was a difficult balance act for black comedians in the southern states of USA.

The Bar-Kays did Soul Finger. They had lost many members in the airplane crash with Otis Redding in late 1967. Perhaps the new line up had not played together for so long. They didn't sound as good yet as before the accident.

Paul Kelly was skinny and sounded like Sam Cooke or Arthur 
Conley. He sang Sam's “A Change Is Gonna Come” and one Arthur Conley number.

A female singer did two Etta James numbers “Tell Mama” and “All I Could Do Was Cry.” (Was it Big Ella?)

Rufus Thomas did "Memphis Train” and “The Dog.”

I think Carla Thomas did “I’ve Got No Time To Lose” and one more number.

Donald Height sang “I Don’t Want To Cry.” He was rather corpulent and when he sang Soul Brother's “Twist” he put on a white wig. He was a good dancer despite his being overweight.

The distance to the stage was long and I have always wondered if this was the real Donald Height (from Shout and Jubilee Records). An article in USA magazine $R n B$ World at this time said that Donald had at least one impersonator touring under his name.

The Delfonics did almost exactly the same show that I had seen at the Apollo: “I'm Sorry," "La La Means I Love You” and “Get Ready.”

(The drummer Al Jackson Jr. was not at all impressed with the group's sense of timing. In the Stax studio on Monday he imitated the group and showed their mistakes.)

Joe Tex was the headliner. He introduced his band and especially Jamo Thomas on bongo drums. He had a hit with "I Spy For The FBI.” Here Jamo did “Knock On Wood.” 
Joe Tex has always been an excellent showman. He did You Better Get It, Men Are Getting Scarce when he invited a girl on stage and she kissed him with a "Greasy Mouth.”

Then followed "Papa Was Too," “Tighten Up” and "Skinny Legs And All.”

As usual his show was an intricate interplay with the microphone. Or a duel, if you like. The microphone stand was rocked in various directions while he danced around it - out of reach. But it always arrived at the right place for Joe to sing another chorus. In Funky Street Joe hit it with a heel kick. Joe's show was very visually effective and physically less demanding than the James Brown show with knee falls and splits.

This night the artists sang two to three songs and only their greatest hits. Al Perkins did a fine job as M.C. His nick name was "Wild Man" but he usually held back and was cool both on radio and live in person.

(I guess the show was called and advertised as the WDIA Starlite Revue: On the internet the following performers are mentioned: Joe Tex, Rufus Thomas, Percy Sledge, The Box Tops, The BarKays, The Intruders, Pigmeat Markham. But I didn't see Percy Sledge, and definitely not the Intruders and probably not the Box Tops.)

Next year the Memphis Mid South Coliseum became the scene for the first WC Handy Blues Festival at the same time as the celebration of Memphis 150-year anniversary as a city.

On the bus from the Coliseum I was informed by a black guy 
that Joe Tex was going to the Hippodrome after the show. My new acquaintance had an impressive "conk" (A processed hair style like Little Richard. It is dangerous as the lye can permanently damage the scalp and its hair cells, which “Cleanhead” Vinson and Nappy Brown have experienced.) We decided to go there. He was almost a look-alike of McKinley Mitchell. Short, slightly corpulent and the same hairstyle. Both had marital problems. My new friend said that his wife had kicked him out a couple of weeks earlier and that he had moved back to his mama. Under the Magnolia trees he started singing Sam Cooke's “A Change Is Gonna Come.” It was already the black national anthem.

Many others had started using the natural hairstyle called “Afro.” You were considered an Uncle Tom if you didn't. James Brown was in the forefront of the new hairstyle and he produced "How You Gonna Get Respect (When You Have Not Cut Your Process Yet)” with Hank Ballard. (Danny Adler a guitarist from Cincinnati said that Hank kept his process well after this recording was released.)

The Hippodrome, the largest black nightclub on Beale Street looked like a combination of a church and storage barn from outside. It was packed and a band was on stage. When we arrived Rufus Thomas demonstrated "The Dog” dance for and with a couple of young girls. They doubled with laughter while trying to follow Rufus instructions. It looked like Rufus wanted to take the girls home with him. I think he had his famous short pants on. It wasn't the usual pastel coloured soul costume.

I managed to call his attention when he left the stage and we 
decided to meet at Stax next week. We exchanged addresses. Rufus lived at 1595 Joyanne St. in Memphis.

But Joe Tex was not there. One year later, while in Stockholm he said that he had been at the Top Four Um instead to meet Roy Hamilton. They were old friends and Roy had helped him in the early days of his career when he was stranded and down and out.

Outside the Hippodrome a bunch of youngsters my own age sat and relaxed. We started talking and next day James Hester and Ingram Munn and my other newly found friends took me to relatives outside of Memphis. They drove past a prison farm and their relatives lived in a shack of corrugated plate where many small children ran around in pools of muddy water. It was a step below those white wooden houses with a small porch that I thought everybody lived in the south.

My presence in a car with black youngsters brought some attention from passing-by policemen but nothing happened.

This gang were also in the outskirts of the music business. They had a little soul band and relatives in Chicago. They planned to go there by car and record. Not a very good idea as it seemed much easier to break through in Memphis. I think they hoped that I would follow and act as a door opener in Chicago.

Monday, July 1

I was on my way to the Royal Recording Studio on $1320 \mathrm{~S}$. Lauderdale and to Willie Mitchell. In the foyer of this former cinema the fruit and vegetable dealer Carl Wells was sitting. He looked like he was in his sixties and his hobby was writing 
lyrics. He showed me a folder with love poems that he hoped that someone would compose songs to. He was going to meet Willie Mitchell and try to get him interested. Last year he had five poems recorded. The best ones so far, he stressed, were "Baby Let Me Be Good To You” (Carla Thomas), “The Hunter” (Albert King), “Sleep Good Tonight” (Sam \& Dave). He was born in Mississippi and wanted to retire soon, so he could concentrate on song lyrics. He had also written lyrics to a couple of other songs that I didn't recognize: "I'll Rather Forgive You Than Lose You” (Bobby Woods) and "Climbing Up To Love” (Melvin Prayer).

Carl Wells was a highly unlikely actor in the music business. But as Knox Phillips had said in the new Sun studio where Sam Phillips had moved in 1959: "Cotton used to be Memphis biggest commodity - now it’s music!”

Willie Mitchell was in the control room while Gene "Bowlegs" Miller was in the studio. It's not impossible that Ray Harris, the Sun rock-a-billy recording artist, was there too as a studio technician. Next year he was presented as vice president and producer for Hi Records. But my interest for rockabilly artists was cold then. In fact I didn’t even know who Ray Harris was.

Willie Mitchell didn't want to say when he was born. Estelle Axton said it was 1933, but he looked a bit older. (Official date is 1928 in Memphis.) His version of "Soul Serenade” had sold very well a few months earlier.

His teens and early twenties were spent on Beale Street. He really enjoyed the jam sessions there, sometimes lasting for a 
couple of days. There he rubbed shoulders with B.B. King, Roscoe Gordon and Johnny Ace.

Willie started to play trumpet and studied music in high school and college. At Rust College, he studied music for three years with Onzie Horne, a recognized skillful teacher. Willie played in the school band and was later offered a seat in Al Jackson Sr's Orchestra (the father of Al Jackson Jr.). Before military service he did a stint in Tuff Green's Orchestra.

He continued with military music in Germany in 1952 and in 1955 returned to Memphis. He played regularly at the local clubs and in 1959 made his first recording with his own band. The Crawl was a minor dance hit. Willie recorded on the Home of The Blues label in 1959 and early 1960s. It was a small Memphis labels that had contracted remarkable artists like Roy Brown and the Five Royales. While Larry Birdsong can be described as "interesting."

In 1968 Willie had had a total six Hot 100 Billboard hits: "Percolatin'," “20-75” where Al Jackson plays the drums, plus “Buster Browne,” “Bad Eye,” “Slippin \& Slidin',” and “Soul Serenade.” (Willie said eleven, and included That Driving Beat and Sunrise Serenade.) Willie had three more hits in the following six months.

Willie usually played the trumpet but on "Soul Serenade" and "Bad Eye" he also sat down at the organ. He had released nine LPs, the latest being Prayer Meeting.

At this time his orchestra included his brother James Mitchell 
(tenor or baritone saxophone), J.P. Luper (tenor sax), Teenie Hodges (guitar), “Larry” (or Leroy) Hodges (bass), Howard Grimes (drums), and Charles Hodges (organ).

Don Bryant was their vocalist and he also recorded under his own name and sang at the major dances in Tennessee, Missouri or Mississippi that Willie's orchestra performed at. He sang on “That Driving Beat," one of my own favourites.

Willie's band was so heavily booked in the studio that longer touring was out of the question. They stayed in the studio during weekdays and performed around Memphis during the weekends. The MGs and The Mar-Keys had had the same routine.

Willie's work as a trumpeter was also requested in other studios and he can be heard on many hits recorded at the American Sound Studios with Wilson Pickett, and on Bobby Womack's What Is This and on Paul Revere's LP Goin' To Memphis.

Willie put his forthcoming album, Solid Soul, on the turntable. Release date was July 15 and he played a few samples like "Grazing In The Grass,” "Windy,” “The Horse” and "Groovin'.”

Willie had also produced Bobby Bland's latest hit which I misheard as "Teach You The Blues," but it should probably be "Touch Of The Blues" (November 1967). He had written "Heartaches" for O.V. Wright and produced his hit "Eight Men Four Women.”

He had also produced Inez and Charlie Foxx. But anonymously, as Charlie had insisted to have his name on the label. He had produced Don Bryant's “Save Me” and played trumpet on most 
of the songs recorded by Joe Tex in Chips Moman's American Sound Studio and on Joe Simon’s “(You Keep Me) Hanging On.”

I think that Dan Penn later told me that Joe Tex did his vocal of "Skinny Legs and All” in Memphis while the audience was added in Nashville.

Willie had written “Comin' On for Bill Black.” It had been a decent hit four to five years ago.

Willie said that what made the Memphis sound unique was that they didn't use written arrangements, but made them up in the studio. Still all his musicians were educated and could read sheet music. Willie also wanted to stress the difference between the Memphis “down beat" and the Tamla Motown (Detroit) "upbeat" and that recordings produced in New York sounded different.

Willie had an offer to tour England August-September 1968, but it didn’t materialize.

Willie was not the only trumpeter in the studio that day. The other was Gene "Bowlegs Miller - and he was worried. For several years he had tried to get a hit but without luck. He was born May 25, 1934 in Memphis and after schooling at the Booker T. Washington high school he and his brother formed a song and dance team called The Miller Brothers. They were later renamed Baby Ray and Bowlegs (1949) and were a regular act on the Beale Street amateur contests. (This is not the Baby Ray who recorded on Imperial.) Among others they were 
accompanied by Andrew Moody’s Band. "Every other week B.B. King won and the next one we did,” exaggerated Bowlegs. By 1952 he was a full-time musician; playing trumpet in all the small places in and around Memphis. He remembered backing the Four Aimes; later called the Four Tops.

He formed his own band in 1957 and in 1960 he was the bandleader for Richard Nixon in his presidential campaign (Also outside Tennessee?). "You can see my face on the cover of Look magazine then,” he said proudly.

Bowlegs breakthrough came in 1961 when he was signed to Vee Jay and recorded “One More Time Part 1-2." "It topped the charts,” said Bowlegs. This success led to an engagement at the Regal Theater with The Vibrations, Arthur Prysock, the Dells, The Clovers and The Sensations. He tried to repeat the success with occasional record releases like "Bowlegs Twist" (on SAB in 1962) which was recorded at the same session as his VJ recording. "Here It Is Now” and “Toddlin',” both on Goldwax did not do well when they were released circa 1964-66. Hi Records contracted him in 1967 and tried to make him into a singer but "Sure Is Good” and "I Was Wrong” didn't do much either. Still he was not without work. He had his own nine piece band with Rufus Thomas son Marvel playing piano and organ. They performed in and around Memphis. He did a lot of session work at for example with Stax, where he was a studio musician for four to five months in 1965. Then he went to Rick Hall's Fame studio in Muscle Shoals.

His trumpet can be heard on LPs with Wilson Pickett ("I'm In Love," "Wicked Pickett”) and Etta James (“Tell Mama”) 
and Otis Redding (“Otis Blue”) and on soul hits like "You're Looking Good,” "Stagger Lee,” "Funky Broadway,” "Mustang Sally” (Wilson Pickett), “Satisfaction” (Otis Redding), "Looking For A Fox" (Clarence Carter) and "When A Man Loves A Woman" (Percy Sledge) and "Shake Rattle and Roll” (Arthur Conley).

He played organ on Pickett's "Sunny" and trumpet on Chuck Berry’s Back To Memphis LP.

He had also backed many artists on stage like The Impressions, the Temptations, Little Milton, Otis Redding, Rufus \& Carla Thomas, Radiants, Mitty Collier, Brook Benton and Marvin Gaye.

He had been on WDIA radio station's "Starlite Review" seven times, and at the W.C. Handy Memorial.

Even if Willie Mitchell was the best selling $\mathrm{Hi}$ artist at this time, in the future he concentrated on record production of southern Soul with artists like Ann Peebles, Syl Johnson, O.V. Wright and $\mathrm{Al}$ Green and with splendid results.

Bowlegs later gave up the plans of a solo career and arranged and produced other people's recordings.

He was not in the same league as Willie Mitchell but he was still doing good work with Margie Hendrix (of the Raelettes) "I Call You Lover But You Ain’t Nothing But A Tramp” and Little Junior Parker, Gloria Lynne and Bobby Hebb’s “Everything Coming Up Roses.” His arrangement of Homer Banks' “A Lot Of Love" is my own favourite. 
At night an excited porter knocked at my door. He asked if everything was alright because there were a group of young black men asking for me in the lobby. It was the gang from the Hippodrome. After this incident I got a royal treatment from the black staff of the hotel.

James Hester and his brother Phillip lived at 249 Ayers Street. Ingram Munn and other friends were there and we listened to records. As usual I was surprised that many of the women that were present already in their teens had children. Now they had left their children at home with their own mothers.

I always walked from my hotel to the Stax Studio across town. I passed vacant lots and buildings that stood empty after the fires four months earlier, and abandoned gardens previously used for growing lawns and vegetables, following the assassination of Dr Martin Luther King Jr.

Out from one of the buildings came a young black man. He wanted to improve race relations and get to know me better and engage in a homosexual activity. He in fact started pulling at me trying to get me into the building. His face was sweaty and it looked like he was using drugs. He didn't look nice at all, but he was smaller than me and I felt I could outrun him.

The very same moment a car stops behind us. It is Howard Grimes, Willie Mitchell's drummer. He had recognized me from the Royal Studio visit. The perpetrator runs back into the building and I'm offered a lift to Stax.

In London's Hyde Park Corner the year before, an English 
speaker had said about homosexuality: "We invented it, but the Americans took over and are much better at it ...” I got plenty of indecent proposals this summer. I moved in bad neighbourhoods. I couldn’t afford taxis and walked.

In safety, inside the Stax building I waited for Rufus Thomas who never showed up. Instead I met Don Nix. He was wearing a big cowboy hat that hid a small balding spot to be. Recently he had been offered a job at Stax to build up a pop and rock catalogue with white recording artists.

Don was born in Memphis in 1941 and played baritone saxophone in the Markeys between 1961 and 1963. He was part of the first horn/reed section at Stax while the rhythm section was Booker $\mathrm{T}$ \& The MGs.

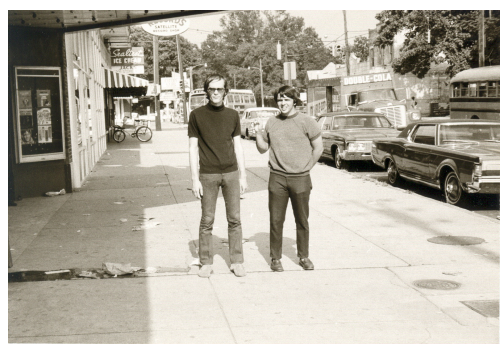

Don Nix (left) and Bobby Whitlock. July 21968.

It was great fun touring all over America after the big success with Last Night. Since the Mar-Keys was a white orchestra but sounding black they were by mistake booked at the Regal Theater. (Don said that they were the first white group at the Regal, but it seems unlikely.) When they came out on stage, the audience became dead silent. The strong searchlights only made them whiter and things worse. Don managed to say "It's so dark - is anybody out there?” The ice was broken. They did so well that they topped the bill and LaVern Baker was moved down to second billing. 
While at southern clubs they were sometimes introduced as a bunch of “o'fays” so that the (black) audience understood that they were both self critical and self ironic and had to distance themselves.

Don narrated many anecdotes from his time at the road. He enjoyed that lifestyle and preferred to work with black artists as they didn't let success go to their heads as many white artists in the same situation.

They had a playful feud with Ike Turner and his Kings Of Rhythm and shot slingshots at each other when they were standing on stage. Don didn't think highly of Ike. He felt that he lacked humour and was stupid. I had not met Ike and Tina yet. But after seeing them on stage I have always felt that Ike was a genius of black show business, as a musician, performer and conductor of a stage show. Still his lifestyle is the stereotyped "pimp and gambler."

Don was very interested in the old school of blues singers still living in Memphis. He spent a lot of time with Furry Lewis and his friends. They sang the blues and drank while Don and his friends listened and drank. At a local Blues Festival one of Furry's friends had been so drunk that he shit in his pants, Don confided. This only strengthened my resolve to concentrate on soul music that summer ...

Don was part of a small colony of southern hippies that had stayed behind and not moved to the freedom on the west coast. Some of the better rock music of the 1970s was created by this 
group of hippies, rebels and outlaws. Don even asked me about the drug supply in Sweden, which I knew nothing about.

Bobby Whitlock walked by. He had just released his first record on HIP, the Stax pop and rock label. Bobby wore a Beatle hairstyle and seemed like an English musician. He was organist in the group around Delaney and Bonnie and Friends. I was surprised when Deanie Parker said that they were a white group. They had a great blue-eyed soul hit with the Stax recording of It's Been A Long Time Coming. It was one of the better songs I heard that summer. Bobby later became part of Derek and the Dominoes (= Eric Clapton).

While we were talking, music and singing were coming out of one of the Stax studios. It was the Soul Children. They were Anita Lewis (=Louis) and "Sheba" (=Shelbra Bennett) and Norman West and Johnny Colbert; a mixed group with two men and two woman.

Isaac Hayes played the piano and in the background was coproducer David Porter while Steve Cropper played guitar and co-produced too, it seemed. The song they were working on was “The Sweeter He Is” and although I didn't stay in the studio so long. I heard the song from outside while they made fifteen takes during several hours. Steve and Isaac tried to find the right groove, but without much luck, I thought.

This was the first time I set foot in a recording studio. This song became a national hit recording reaching no 52 on Billboard's chart. It was a good omen. But the finished version, released 
in 1969, didn't really sound like those takes from this June(?) session 1968.

Don told me about a recording session with Carla Thomas some years earlier. It was raining and suddenly rain poured in through the roof. It assembled in the lowest part of the movie saloon. All musicians had to move to higher located parts and gather round the only one still working microphone there.

After the session with The Soul Children I had a talk with Steve Cropper. He was extremely busy in those days.

The piano and saxophone are my favourite instruments, and among all guitarists in $R \& B$ and soul music there are only a handful that I rate very highly. They are Chuck Berry, Bo Diddley, Mickey Baker (Of Mickey and Sylvia fame, and studio guitarist at Atlantic Records), Loman Pauling (of the 5 Royales) and Steve Cropper.

Booker T. \& The MGs, for which Steve Cropper was the guitarist, had been elected the top American instrumental group by Billboard in 1967 and their "Hip Hug Her" was voted the number one instrumental song in the NARAS poll the same year.

Steve had the major part in that group. Even if Booker T's name is featured it's Steve who was the group's engine. As a producer and songwriter he made sure that the members' best ideas came to the forefront. Until Jimi Hendrix surfaced, Steve was the most respected contemporary American guitarist in England.

I felt that among white producers Jerry Wexler (Atlantic), Chips Moman (American Sound Studios), Bert Berns (Atlantic and 
Shout Records) and Rick Hall (Fame studios in Muscle Shoals), Steve was perhaps the one who understood best how soul music should sound - and especially how the guitar should be played and sound on a soul ballad.

It was a great moment to meet him again. (I had gotten his and the other artists autographs at the Stax Volt Tour the year before.)

Steve was born on October 21, 1941 in Willow Springs, Missouri. At ten years old his family moved to Memphis where he entered Messick High School and then tried to become an engineer.

During the high school days he and friends formed a band which later became the Mar-Keys. At the end of the 1950s they mostly performed Ventures and Duane Eddy material. While growing up Steve had almost exclusively listened to Country \& Western. But during his high school days he was more exposed to R\&B and Lo(w)man Pauling and the 5 Royales became his major favourites.

The 5 Royales were based in Winston-Salem (North Carolina). When they left King Records they recorded for the Home of The Blues label in Memphis. Steve and his friends had an opportunity to see the group. It is not difficult to understand why Steve fell in love with Loman's style. It's extremely rhythmic while accompanying and explosive in the solo work. Not unlike the work of Mickey Baker, the best of the R\&B solo guitarists, but more rooted in the gospel tradition.

Steve's own style is rather dry moving up and down the scales 
with perfect timing, while he holds the recording together. He creates a sort of counterpoint to the explosive, emotional singing and the heat of the horn section. It's an instantly recognizable guitar style even when disguised outside the Stax banner at for example Danny White's Atlas recordings (“I'm Dedicating My Life”).

Around 1960 the Mar-Keys started to include more R\&B material in their repertoire. Steve got a job in Estelle Axton's Satellite Record shop with the intention to be near the newly opened studio. Quite a few people had started to hang out there. Some were just curious while others turned out to be fine musicians. Soon a kind of regular studio band formed and when Steve met Booker T. in 1961 things started happening.

Booker T. Jones was born on November 12, 1944 in Memphis and went to the Booker T. Washington High School. He studied music alongside his studio work. In 1966 he graduated in music at Indiana University. While growing up he listened mostly to blues and gospel but became more and more fond of classical music while studying.

Al Jackson Jr. was born on November 27th 1935 in Memphis and also attended the Booker T. Washington High School. This was before the bussing era. I guess most black students went there. He learned how to play drums from Houston Stokes, drummer in Al's father's 16-piece band. He succeeded Stokes there before forming his own band by the mid 1950s. He was also engaged in tours with the Jazz Prophets and Roy Milton's Solid Senders. Al Jackson's background was jazz and blues. 
Donald "Duck” Dunn (bass player) was born on November 24, 1941 in Memphis. He was living on the same street as Steve and went to the same school. Steve taught him the basics when Duck got his first guitar in 1957. Duck's musical background was pop and $\mathrm{C} \& W$, but he was never as fond of $\mathrm{R} \& \mathrm{~B}$ as Steve, but kept contact with new happenings in pop and rock.

These four men formed a core group that was present on more and more recordings, often augmented by the Mar-Keys horn section.

Jim Stewart, who mostly handled the control board, felt that they should try recording themselves.

The opportunity arrived in 1962 when another session was finished long before due time.

First recording is "Behave Yourself.” Jim liked it and requested a B-side. They started improvising around an old riff and "Green Onions” was born. Duck Dunn was not in the studio that day. But he has soon taken Lewis Steinberg's place behind the electric bass.

The Mar-Keys changed members often, but from the mid 1960s the horn section most often was Andrew Love and Joe Arnold (saxophones) and Wayne Jackson (trumpet).

About $75 \%$ of all arrangements were born in the studio. When they backed other musicians or recorded themselves new ideas were born. "The best ones appear when the technician has stopped the tape machine. Then we find new stuff to be used later," said Steve. 
Despite all success Booker T \& The MGs were a studio group in 1968 only doing two concerts a year. Plus a few disc jockey birthday parties to please them and to make them play more Stax music on the air and maybe a few school concerts and dances in and around Memphis every year.

In 1968 the Stax studio was busy almost round the clock. The MGs had taught a group of black teenagers - The Bar-Kays - to take over $50 \%$ of their own studio work. But the Bar-Kays were in the same airplane as Otis Redding when he was killed. Only Ben Cauley (trumpet) survived the crash and James Alexander (bass) had stayed at home. Soon another Bar-Kays group was formed.

There were forty recordings with Otis in the can. Steve said that Otis had been extremely easy to work with. He was liked by everybody and never caused any problems. But Wilson Pickett was very difficult to work with. They had to let him go. Which was a great pity as he recorded some of his best work there (“In The Midnight Hour,” “Don’t Fight It,” “634-5789,” “Ninety Nine And a Half Won’t Do”).

Homer Banks 


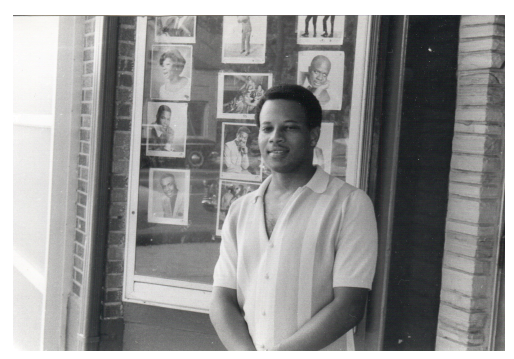

Homer Banks

Earlier that day Don Nix had introduced me to Homer Banks. He was a young, rather withdrawn and shy, nice young man. He had three soul hits behind him but had not been comfortable with life as a touring artist on the road. Instead, he was now a songwriter and producer, preferring the relative calmness at Stax.

He was born on August 2, 1941 and also a student at the Booker T. Washington High School where he got to know Booker T. Jones and David Porter.

Homer sang gospel in groups like the Soul Consolators, but without making any records. He spent a lot of time at Beale Street where his major favorites B.B. King and Bobby Bland sometimes performed. Directly after high school he did his military service in West-Germany.

Homer won an amateur contest in Germany and toured and sang at military bases in Germany. Back home again he decided to be an artist.

He hooked up with David Porter who worked at Genie Records. Homer got a contract and recorded "(Little) Lady Of Stone” / “Sweetie Pie.” It was a decent hit in 1963. Around the same time Liberty/Imperial reactivated the Minit label for soul recordings and Homer was their first artist. 
In 1964 the Bowlegs Miller produced "Lot Of Love" and it becomes a huge hit. Now Don Nix entered the conversation and said with emphasis that Spencer Davis huge hit "Gimme Some Lovin"” is based on the guitar riff from "Lot Of Love." The follow up “60 Minutes Of Your Love,” written by Deanie Parker and Homer Banks also did very well the year after. As did "Hooked By Love" and "Round The Clock Lover Man.” The formula from the first hit was repeated. His recordings don't have a pure Memphis Stax sound.

In 1966 he was contracted by Stax as a songwriter and has since written for Sam \& Dave, Johnnie Taylor, Carla Thomas, Wilson Pickett and others and produced Jeannie \& The Darlings.

He became part of the song writing team called We Three. Another member was Bettye Crutcher, a very attractive woman in my own age. She had already written some very bluesy songs like Albert King's You Drive A Hard Bargain and Johnnie Taylor's Somebody's Been Sleeping In My Bed. She played some of her compositions for me in the Stax mail room. It was full of packages of 45s. Some with Stax records going out to radio stations and some had come in from other labels wanting to have their records distributed by Stax or included in the Stax catalogue.

The Eddie Floyd session

I kept a close watch at the studio. Eddie Floyd was coming to record. I didn't want to miss that.

The Soul Children's session had not been a spontaneous, 
improvised "typical” Stax-session. The four singers had to sing according to Hayes \& Porters instructions. Every line was repeated until it sounded OK. The group had been put together as a replacement for Sam \& Dave and also to capitalize on new softer, soul trends. It was my first visit in a recording studio. It gave me an insight of the not too bright future for the Stax sound.

Eddie Floyd, on the other hand, was a real veteran. He had more than ten years of business experience. He and Steve Cropper had been a team for years, and Steve always played on and produced his stuff. Their "Knock On Wood" is a true classic soul recording of the 60 -s and had been performed by numerous artists. Recently Eddie’s “I Never Found A Girl” had sold very well.

Eddie brought food to the studio and he and Al Jackson Jr. started eating. African-Americans wanted to find their roots and Soul Food had been their food through history. I, on the other hand, only knew dishes like Chitlins, Ham Hocks, Fried Chicken, Collard Greens and Red Beans and Rice from hit recordings.

Meanwhile, Steve Cropper and James Alexander laid the foundations for the guitar and bass. It took about half an hour before Steve was satisfied. Meanwhile Booker T. had arrived from Los Angeles. He was composing the soundtrack music for a film there. (Uptight, directed by Jules Dassin.)

Homer Banks walked in with more food and wine. He and Eddie sang a duet before sitting down to eat. Ron Capone objected from the control room. This studio was not a restaurant! 
Ron, formerly at the Pepper-Tanner studio had started at Stax only two weeks before Otis Redding died. Jim Stewart, who spent much time in the studio before, had delegated his work to Ron now.

The horn section arrived (the "Memphis Horns" name was not used then). Wayne Jackson (trumpet) mixed a cocktail of cherry wine and fruit soda (7 Up), and whispered to me that this was really the secret of the Memphis Sound and its heavy backbeat. Luckily the Motown spies had not found that out yet...

Wayne invited me to his home and seemed disappointed that I was living at a hotel and could not stay in his home... It was a great example of southern hospitality.

The reed men, tenor saxophonists Andrew Love and Joe Arnold unpacked their instruments from the cases. It took only a couple of minutes for Steve to say which key to use, and to instruct the horn section. Eddie hummed the melody and Booker T. played the piano. Steve and James Alexander played the background and Steve held up his hand in the air at various levels and the horns just filled in.

It seemed like they just walked in and Steve waved his hand and the horn arrangements were finished. It was telepathic and called a "head arrangement.” No sheet music was needed.

Steve, who writes with his left hand but plays the guitar and does everything else with his right hand, gave the musicians their last instructions, and then strapped the guitar band around his shoulder. 
The first song "I Need You Woman” was a typical stomping Stax number. A four-channel tape recorder had been recently bought and this is how the microphones were connected;

Channel 1: Bass and horns

Channel 2: Vocal

Channel 3: Piano

Channel 4: Drums and guitar

The piano was separated from the rest. Steve was not $100 \%$ satisfied with Booker's playing. This way it could be adjusted later.

\section{Take One!}

Eddie had written the lyrics on a piece from a brown paper bag and held it up in in front of him.

They did three takes in a row. The fourth was stopped in the middle when a guitar string was broken. For superstitious musicians it meant that the recording was going to be a hit. Steve was however not totally happy with the guitar and bass and he and James started all over. But they gave up after a while and all agreed that take number three was the best.

The songs recorded that night came out on Eddie Floyd's Stax album STS 2002 called "I’ve Never Found A Girl.”

On “I Need You Woman,” Booker T’s piano is almost omitted and male and female singers have been added - perhaps on channel 3. Otherwise it sounds identical to what I heard then. 
The Memphis horns had done their part for tonight and left. It was going to be a long day in the studio tomorrow.

Al Bell, the Stax vice-president, came into the studio. He had written "And I Love You" and wanted to co-produce it with Steve. Duck Dunn took over the Fender bass. Without wanting to disturb, he had before walked in and out of the studio, checking how his young adept did.

The microphones were re-arranged this way:

Channel 1: Bass (Duck Dunn)

Channel 2: Guitar (Steve Cropper)

Channel 3: Vocals (Eddie Floyd)

Channel 4: Drums (Al Jackson Jr.), Piano (Booker T. Jones)

Horns were added later. It was a fine ballad with a vintage 1950s feeling that Al Bell had written. Eddie put his soul into traditional lines like "You were just sixteen and everybody knew you were my teenage queen” etc. After three takes everybody was happy. The songs was then 5'20", but Steve thought it could be shortened to 3'40". When the recording was released it was called "Girl I Love You” and had a length of 3'15" and a vocal group and horn section had been added.

The third song that evening was a fine, fast soul number called "I'll Take Her." At first Eddie ran into problems when he, by mistake, found a leaflet for used cars instead of his self written lyrics in his pockets. This incident met with lots of laughter but then they did three takes in a row here too. Later they added a vocal group and horns. 
Everybody was happy. Three songs had been recorded in four and a half to five hours after the microphones had been set. There had been some eating first and in between everybody assembled in the control room and listened to the takes.

After World War II and up to the late 1960s a studio was booked for three to four hours. In $R \& B$ and Soul it was expected to record four songs of which two were A sides and two were Bsides. This way the record company had both a current record to release plus a follow up. Of course, the artists had rehearsed before so all songs were ready to be recorded. If they didn't use the touring band I guess written arrangements had been prepared in advance instead.

The record session had been totally free from emotional outbreaks or drama. It had been very relaxed but no one had forgotten why they were there. Like myself, many people rated Booker T \& The MGs the very best studio group at this time.

Eddie had to get up early the next morning. He was going on a 49 days long one-nighter tour, with one performance every night. During the first half of the tour Percy Sledge, Arthur Conley and Little Willie John's sister Mabel were the supporting acts. In the second half of the tour they were replaced by Joe Simon and Jeannie \& The Darlings.

I guess that after seven weeks of traveling Eddie's voice would sound a bit worn. It was wise to record songs for his forthcoming album now, when he was in top form. 
Eddie sounded tired when he talked about this long tour, but the payment was good, of course.

Eddie had a long career behind him. He was one of the members of the Falcons that was founded in 1956 in Montgomery, Alabama. They deserve the title "super group," as the members were Wilson Pickett, Eddie Floyd, (Sir) Mack Rice who did the original Mustang Sally and Willie Schofield. Eddie's uncle was their manager. They were a gospel group in the beginning but gradually started singing R\&B to gain more work. James Brown and the Famous Flames and the 5 Royales had done the same.

I walked home under the clear star-lit sky. The cicadas were playing and I was very happy. I had experienced the very best of Memphis soul. It had been one of those rare occasions when I felt that musically it was not possible to see and hear something better anywhere in the world.

The next day I took a bus to the address listed in the phone book for Goldwax Records.

I came to a pharmacy, but no one there could really tell me anything about this record company. Instead I got this info from a local Memphis newspaper's business pages about the local record scene in 1967.

Doc Russell was born in the early 1920s in Taylorsville, Mississippi and belonged to the generation who danced to the visiting big bands at Hotel Peabody.

He became a pharmacist in 1948 and after ten years he and his partner owned four pharmacies in Memphis. The record 
business in Memphis was expanding and successful and in the early 1960s he recorded a C\&W-artist, without any success. But the next single is a great hit and Doc has found the model for his newly formed Goldwax label. (A partnership with Quinton Claunch is mentioned nowadays but not in this article from 1967.) The record was O.V. Wright's That's How Strong My Love Is. It sold 200,000 copies mainly in the south and was covered by Otis Redding.

O.V. soon went to Don Robey's Back Beat label. Evelyn Johnson, who did most of the practical work there and ran Robey's labels remarked that O.V. looked like a country preacher. Who could believe that he was a heavy narcotics user?

Goldwax soon found James Carr to replace O.V. For a while he seemed like Otis Redding's crown prince but personal, psychological problems landed his career in backwaters.

Other fine Goldwax artists were Spencer Wiggins, and the Ovations, which had a lead singer who sounded just like Sam Cooke.

But despite all great talents Goldwax went bankrupt in the late 1960s.

Chips Moman’s American Sound Studios

Bus timetables were usually missing on the pole at the bus stop. After a couple of hours waiting for the bus in the scorching sun it finally took me to 827 Thomas Street. Here lay Chips Moman's studio, not unlike a modern Swedish church building with a slanting roof. It had become one of the best studios in Memphis 
and not exclusively for soul music. At one time in 1967 no less than eleven of the Hot 100 songs in USA were recorded here.

The studio was owned by Chips Moman and Don Crews handled the financial side.

Chips was born in 1938 and started playing guitar at an early age. At fifteen he moved to Memphis. Soon he dropped out of high school and starts playing with the Mar-Keys and hang out at Jim Stewart's barn. He made a living as traveling gas station painter with the southern states as his district.

He helped Jim Stewart and learned a lot. In 1962 he felt that he knew enough of record producing and opened his own business. The big commercial breakthrough came with the Gentry's Keep On Dancing (1965) but before that he had recorded lots of soul hits too.

The usual routine in 1963-64 was that Atlantic sent their soul artists to the Stax studio. But although the Stax studio was open round the clock they couldn't accommodate all; and those were sent to Chips Moman. When Rick Hall (In Muscle Shoals) showed strength, he got those who wanted to change their sound a little. Eventually the circle was closed when artists were sent to Philadelphia. In the early 1960s a lot of great soul had been recorded in New York and Philadelphia.

Among Chips Moman’s greatest successes were:

Joe Simon "You Keep Me Hanging On,” Joe Tex “Skinny Legs And All," Wilson Pickett "I'm In Love," "Funky Broadway,” Sandy Posey “Born A Woman.” 
The regular studio band was Reggie Young (guitar), Bobby Emmons (piano), Mike Leech (bass), Gene Chrismon (drums). While Chips, Dan Penn and Tommy Cogbill were the producers.

It was July 3, the day before national holiday on the fourth of July. It started getting late in the afternoon and in the studio was only Dan Penn, a sound technician, and Alex Chilton, the singer of the Box-Tops. He added the vocals to "I Met Her In Church.”

Dan had produced their big hit The Letter and also the follow ups "Neon Rainbow," "Cry Like A Baby" and "Choo Choo Train.”

The Box-Tops were Tom Boggs (drums), Rick Allen (organ), Gary Talley (lead guitar), Bill Cunningham (bass) and Alex (vocals).

Dan was a legend to me and I guess he was flattered that I Dan Penn was only interested in his career and not Alex Chilton's, despite that he was a major pop name.

Dan was born in 1941 in Vernon, Alabama and grew up on a little farm and had to do all kinds of chores.

At sunset around six o'clock at night the family went to bed so 
there was rarely time to listen to anything else than C\&W on the radio. Dan sang in the small, all-white country church, both in the choir and solo. When plowing he used to set music and words to the monotonous thumping of the plow. His major idol was Hank Williams. At the age of thirteen, while still in high school he formed his first band. Song selection was exclusively $\mathrm{C} \& \mathrm{~W}$, but he had started to listen to R\&B.

A couple of years later he met Rick Hall, another C\&W fanatic and Billy Sherill, who played the tenor sax. They form a band where Dan sang and played a little guitar.

When Dan is sixteen he started spending quite a lot of time in Muscle Shoals where Rick had started to build his Fame studio.

Dan was no longer only writing for his own band but tried to get others to record his songs. A first taste of success was "Is A Bluebird Blue?” with Conway Twitty (1959).

Dan got his high school diploma in 1960 and worked for a short time as a clerk in a book shop. Three months later he was back with Rick Hall.

Dan formed a new band called Mark 5. They played almost exclusively $R \& B$ and they also formed the nucleus of Rick Hall's studio band.

In the mid 1960s the band moved to Nashville and started working in studios there. In the early 1960s the white audience in the south wanted a mixture of Little Willie John, Chuck Willis, Ivory Joe Hunter, Fats Domino and blues a la Jimmy Reed plus the Bo Diddley Beat and a topping of the early soul 
of Bobby Bland and Ray Charles. "That's the way we sounded,” said Dan. When Mark 5 had abandoned him Rick and Dan started a new band with Spooner Oldham (piano), Jimmy Johnson (guitar), and Roger Hawkins (drums).

Dan considered Jimmy to be the world's greatest "chinker" which means a rhythm guitarist striking the same chord all the time using the guitar as a rhythm instrument.

Dan made vocal sides on Fame without success like "Close To Me” / "Willie And The Hand Jive," and they leased "I'm Your Puppet” to MGM. Although Dan has had much greater success as a songwriter he still kept his dreams of a singing career alive and had a new session planned pretty soon.

Dan Penn and Spooner Oldham, another blue-eyed soul brother formed a composing team which became as respected as Hayes - Porter. Their names are seen on hits like "I'm Your Puppet” (James \& Bobby Purify), “It Tears Me Up,” “Out Of Left Field” (Percy Sledge), "You Left The Water Running” (Billy Young), "Uptight Good Woman” (Spencer Wiggins), “Dark End Of The Street” (James Carr), "Do Right Woman - Do Right man” (Aretha Franklin) and many more. It wasn't B-sides or LP-fillers but the very best songs these artists and many more recorded during long careers.

My own favourite these years was “Two O’Clock In The Morning” with the Spooner's Crowd. It was released by Chess. Dan said that he was playing guitar, talking and making the footsteps. The song is about a guy asking a woman for a dance 
and then follows her home. It's an instrumental plus sound effects that created interest among soul fanatics in the 1960s.

In 1966 Dan started working with Chips Moman. Up until that time he had mostly toured and composed. Now he is assigned as a composer. His first production, “The Letter” with the Box Tops turned out to be the very best selling record of 1967 !

In 1968 Dan planned to start his own business with Spooner Oldham. The record company was called Pacemaker and the artists were Eddie Hinton, Donna Harkey, the Bushmen and George Bird \& The Dominoes.

In 1968 there were circa ten recording studios in Memphis. I didn't have the time to visit them all but in 1967 there were circa 400 singles produced in these studios, of which Stax did 47 and Hi circa 30.

Stan Kessler was about to open a new studio at 904 Rayner. He was born in the late 1920s in Oxford, Mississippi. He started to play the mandolin with among others Rex Rorian and the Caradine Boys. They had their own radio show at WDIA that was sponsored by Caradine (a patent medical tonic, I believe).

He started playing for Sam Phillips and wrote some of Elvis's first recordings. In 1958 he and Clyde Leopard opened a small studio called L\&K at the crossing of Main and Jefferson. In 1960 he and Jack Clement opened a more professional studio, ECHO, at 13 North Manassas. In 1964 he produced Sam The Sham's "Wooly Bully” and also the follow up "Little Red Riding Hood."

Ardent studios was mostly used by record companies out of 
Memphis, especially Mercury which was the only outside company with a local office in Memphis. John Fry was in charge and in 1967 they recorded circa 200 sides, of which Mercury was responsible for 25 .

Ronnie Stoots, who had been affiliated to Stax and among other things made the layout for several album covers, planned to open his own studio in 1968.

\section{Syl Johnson}

In the evening I made another visit to the Paradise Club to see Syl Johnson, whom I had met previously at the Bonanza Club in Chicago. Syl was an excellent showman. He was given a large space in the book Right On: From Blues To Soul In Black America by Michael Haralambos. (The book was later re-titled: Soul Music: The Birth of a Sound in Black America with DaCapo Press.)

On stage he mixed his major soul hits "Sock It To Me” and "Different Strokes" with excellent bluesy versions of Joe Turner's/BB King's “Sweet Sixteen” and Johnnie Taylor's “I’ve Got To Love Somebody's Baby” that he spiced up with his own guitar playing. Otherwise his own favourites are Jackie Wilson and Ray Charles.

The climax came during "Sock It To Me” when he invited a young woman from the audience and together they danced with such sexual overtones that the jealous boyfriend rushed to the stage and dragged down his girlfriend from there, to the delight of the rest of the audience. 
Al Perkins, who was an old friend of Syl from Chicago gave the show a lot of airplay. Probably at discount as air time is very expensive at USA's number one soul station. But the Paradise was far from full. It was Memphis’ largest soul club and I think they could pack in almost 500 seated customers at the tables and perhaps as many standing guests. The Paradise was a natural stop for the more popular visiting soul artists like Bobby Bland or Sam \& Dave. But probably not large enough for the most popular ones like James Brown, the Temptations and Aretha Franklin who could fill large arenas.

Syl was touring by himself and was accompanied by local pick up bands. It had probably been a while since he was in Memphis as he was as surprised as I was by the local alcohol restrictions. He had to do without the usual shot of whisky before his show as the Paradise didn't serve strong liquor.

In the parking lot his red convertible of recent make was admired by a group of pre-teen boys. One was the brother of a singer in the Stax group the Astors. (Their biggest hit was "Candy.”) It's one of the few groups that Stax had had any success with, in contrast with Motown who did best with groups.

When we talked there were some bitterness in Syl's voice. He had worked very hard for ten years without achieving the success he deserved, he felt. He was thirty years old and soul music was very demanding physically. It was not possible for him to continue for many years at the same pace. He had been celebrated as one of the most popular newcomers in 1967. But I could see with my own eyes that only about six months after his last big hit had left the hit-lists and people were not turning out 
in large numbers any more. His two big hits also had a short life span using popular phrases of the day. They were good, but not the stuff that evergreen classics are made from.

He traveled in a fine, shining red cabriolet, but it was not a Cadillac or even this year's model.

Memphis was a weekend city. Compared with Chicago, New Orleans, Houston or Los Angeles the clubs were pretty quiet during weekdays. While the recording studios were busy.

Next morning, when I carried my suitcase to the reception there were some excitement among the staff. At the front door, at the staircase, one of the regular hotel guests had collapsed. He was too tired to climb the step as he had started celebrating the 4th of July very early in the morning.

Myself, I was on my way to Atlanta where I managed to catch a short glimpse of John Wayne in the parade.

Memphis and Chicago were opposites. In Chicago, there were a lot of clubs with brilliant artists. But the recording studios were empty and many had lost hope.

There were certainly clubs in Memphis too (The Paradise, Rosewood, the Hippodrome, Handy and Tiki) but they blossomed during the weekends, while the studios kept a busy schedule sometimes round the clock. If your record was played on WLOK it could break out all over USA.

While the soul music scene in Chicago was an all-black affair, in Memphis there were quite a few white people not much older 
than myself doing great work. Not as singers, of course, but as instrumentalists, producers and songwriters.

My radio was on most of the time. I preferred WLOK. There were more talk on WDIA and the pace was slower; perhaps especially on Rufus Thomas shows around midnight.

These were the best new songs I heard in Memphis:

"River Of Tears"-Gene Chandler "It Should Have Been Me”-Gladys Knight \& The Pips “Never Do You Wrong”Joe Tex “Soul Meeting”- The SoulClan "Competition Ain’tNothing”-CarlCarlton "Cry Baby Cry”-Clarence Carter? “Prayer Meetin””-Willie Mitchell Arthur Conley’s new 45 "Working On A Groovy Thing”-Patti Drew "Face It Girl”-Nancy Wilson "Here I Am Baby”Marvelettes "The Love I Found In You"-Brothers of Soul “Look Of Love” - Walter Jackson “ToLove Somebody” - Sweet Inspirations "My Baby Loves Me”the Chi-Lites “Ain't No Reason For Girls To Be Lonely”Bobby Marchan “Here Comes the Judge”-Pigmeat Markham “Tell Me The Truth”-Gene Chandler, "Psychedelic Soul," “Cry Baby Cry” - Van \& Titus “Send My Baby Back”-Freddie Hughes “Tell Me The Truth”Billy Stewart. a duet (a la Marvin Gaye \& Tammi Terrell) with Jim \& Jean “In the Meantime”-Tommy \& Sherry "God Bless Our Love" - the Ballads "I Got The Sweetest Feeling”- Jackie Wilson “A Long TimeComing” -Delaney \& Bonnie “Funky Way”- Calvin Arnold(Venture Records) “Competition Ain’t Nothing”- Carl

Carlton Harvey Scales \& the 7 Sounds latest "Whatever Hurt You" - the Mad Lads "Does Your Mama Know About Me" - Bobby Taylor \& The Vancouvers "Save It Over Me" 
- Solomon Burke "Do You Know" - Sam \& Dave "What A Man" - Linda Lyndell (blue eyed soul on Stax) "Hard To Handle" -Otis Redding "Give Me One More Chance" Wilmer \& TheDukes "I Never Found A Girl" -Eddie Floyd“"

My time in Memphis was probably the most musically satisfying time I ever have had. Still the address book contained unvisited places like Memphis Delta Record Dist. 596 Lane Ave, and the William Herbert Brewster Church. Renowned gospel scholar Horace Clarence Boyer (of The Boyer Brothers who recorded on Excello, Vee Jay, Chance and Nashboro) said that during a research trip to Memphis he found a picture in the church office which represented a very young Elvis Presley among an otherwise nearly all-black audience. Herbert noted that Elvis always used to be in the church on Sunday evenings when they had radio broadcasts from there.

I think it’s fair to say that soul music in 1968 was in decline.

All major names were still performing except Otis Redding and Sam Cooke who were dead. But the audience had listened to the same music for five years and was expecting something new. It was time for a change. But it didn’t change for the better when also strong economic forces came into play.

First Stax was sold to Gulf And Western and the bottom line became much more important. An LP catalogue was built up with lightning speed with substandard material. 
Berry Gordy somehow lost control over his Tamla-Motown empire. Rumours said that organized crime had taken over. Tamla Motown was said to be the most profitable company in America in all branches and sizes. Stax was not long after. It was very tempting for big business to move in and address a now large white customer base.

When Martin Luther King was killed more militant forces gained control. Whites could not move as freely as before and were not always welcomed at black clubs.

The language of the Black Panthers changed the song lyrics from optimistic to more realistic and violent. Last but not least a drug epidemic of epic proportions broke down the fabric of black society and introduced violence on a scale not seen before. 


\section{Atlanta}

July $4-10,1968$

Thursday, July 4

I arrived in Atlanta on Thursday, the fourth of July. In Atlanta, the unofficial capital of the southern states of the USA, the National Day was celebrated. When the bus from the airport turned into the city center, the big parade was in full swing. John Wayne was the main attraction, and the part of the parade where he was had just passed the jubilant spectators.

I registered at the Falcon Hotel on 180 Luckie Street. It was just a few minutes walk from Peachtree, Atlanta's main boulevard. I lived in the center, but in very rundown blocks. When I returned ten years later, the hotel and its surroundings were completely demolished and turned into skyscrapers and parking lots.

The strategy from the Vietnam war - nationwide asphalting had been successful at home.

A few minutes later I had left the hotel and was on my way to 
radio station WAOK on 113 Edgewood Road. They later moved to no 1 on the same street. I met Gary Edwards who advised me about clubs I should visit. There was VFW on 82 Piedmont and Pink Pussycat at 1237 Simpson. There was a big gospel gala at the city Auditorium on Sunday. But tonight, The Magnolia Ballroom at Sunset/Magnolia NW sounded most interesting (I might have confused it with the Pink Pussycat).

Eddie Billups and Laura Lee were advertised here. The club was located outside the city center, in an area where shopping centers and supermarkets were part of the townscape.

I started on a long walk and on the way I walked by the Birdcage and turned into Auburn Avenue for a while. This was Atlanta's main black entertainment street and I stopped at no. 187 1/2 where the Royal Peacock was located. But inside the glass image cabinet outside there were no pictures of coming attractions. Only the brief and sad message that the legendary R\&B club was closed during the summer for renovation.

Moving on and halfway to my goal I was verbally attacked by a young man sitting on a staircase across the street shouting at me that he wanted to "knock my eyes out." He stood up, but he didn’t come any closer. It was an empty threat.

The Magnolia (or the Pink Pussycat) was a big and rather luxurious club with modern furnishings in a newly built building which held up to 400-500 patrons. It was a glass and concrete place and many could sit at comfortable tables. 
Soul Music Monthly

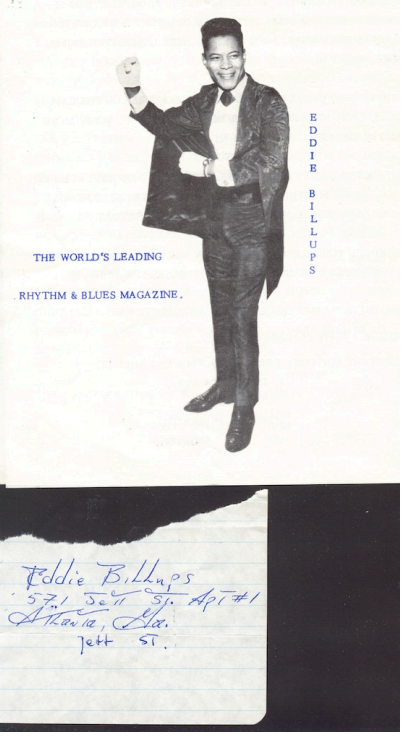

Eddie Billups

Eddie Billups had been a poster boy in a Shout Magazine leaflet to subscribers about a year earlier. He was dressed in an elegant cape on the photo. He confirmed that he had met a couple of Englishmen last year who had taken pictures of him.

I had not heard any of Eddie's recordings then. But the records he had made before we met were fine - for example "No Love Have I" and "I Won't Be Around (Josie)" and "My Faith In You" (Maxx) while later stuff had not been that interesting. (His 1950s recording of “Hard Headed Woman” is a crying song, that Atlanta's Tommy Brown specialized in.)

Eddie told me that he was born in Brooklyn in 1938. (Now, he lived at 571 Jett Street apt. 1, in Atlanta.) He had been a soloist in Mount Pleasant Baptist Church Choir between 1945 and 1955. Then he started singing R\&B. In 1955 he also joined the army and stayed there for six years. He played trumpet and organ in a band and was stationed in both Japan and Germany and met and sang with Lloyd Price, Elvis Presley and Bob Hope.

He left the army in 1961 and got a recording contract with Fleetwood Records in New York. He recorded Let's Dance and that sold well. He was produced by Bob Goldstein who also worked with Little Anthony and the Imperials. Then followed 
Maxx Records where he recorded "My Faith In You Will Never Die” (1962) and "New York Kangaroo” (1962). In 1963 he was contracted by Sure Fine Records and recorded "No Love Have I" and "My Girl” (1964) - which is not the same girl that the Temptations sang about. Eddie sang lead with the Larks on The Jerk, which was released on the Money label, a Los Angeles company owned by John Dolphin. The other two members were Billy Moore and James Bryant. The recording session took place in New York.

In 1965 he came to Jubilee and did "I Won’t Be Around" and “Ask My Heart” (1966). In 1967 he was with Wynn Records and recorded "Soldiers Prayer" (1968).

He toured with Gladys Knight \& The Pips when both were on Maxx Records. He did one week with James Brown playing the organ.

The contact with Gladys and Maxx Records came through Eddie's wife's uncle who knew the promoter Teddy Powell.

He entered the University of Maryland in 1966 and started to study medicine. Now he was a student at the Emory University in Atlanta and didn't really know if he was going to focus on medicine or on music. He was hoping to get his own TV show. If that didn't work out, invest in medicine instead. I think that it became medicine eventually. His show that night was not that terrific. There were many artists around just as good. Still, I saw his name in the cast of the TV series I'll Fly Away. I think his character there was called "Jonah." 
On stage tonight he did among others: "Yesterday" (Beatles), "Knock On Wood" (Eddie Floyd), "Bewildered” (James Brown's arrangement), "In The Midnight Hour” (Wilson Pickett).

Eddie was a quite nice and cultivated acquaintance. But Laura Lee never showed up. She was in fact one of the most talented female soul singers then - living in the shadows of Aretha Franklin. Laura was the main attraction tonight and Eddie had not really been able to fill the void left by her.

Then came a pretty good Otis Redding imitator whose name unfortunately is missing from my archives. In the audience I still remember the young man sporting an enormously high red conk. This was obviously a town where people still remembered and cherished the outrageous hairstyles of fellow Georgians Billy Wright, Little Richard and James Brown.

Friday, July 5

Next day I went back to WAOK. I met Zenas Sears. He had not been there the day before. His name was high up on the list of important contacts that had been supplied by the brothers George and Ernie Leaner in Chicago. Behind his unusual first name hid a very nice white gentleman in his fifties. In fact he was both kind and unassuming - attributes seldom used to describe a DJ.

Like Jim Stewart, founder of Stax Records in Memphis, he was more like a university teacher, or a cultivated banker, than a trendsetting disc jockey.

Still he had - long before Alan Freed started playing R\&B and 
renamed it Rock and Roll - played this music for an exclusive black crowd, which eventually included more and more white listeners.

Zenas was also politically engaged and worked against populistic racists like George Wallace and Lester Maddox.

Lester was the brightest political star at the moment in Georgia. He had reached international notoriety a few years earlier when he chased away black customers from his own diner with an axe in his hand.

Alabama governor George Wallace had worked against Martin Luther King Jr with all his might. (But he regretted it later and asked the people he persecuted for forgiveness.)

Zenas then told me briefly about his life and about the Atlanta R\&B scene, but it was only ten years later that I got the full story.

He had been stationed in India during World War II. His mission there was to manage a radio station, mostly for black troops. I guess they were involved in the skirmishes so entertaining described in the movie Objective, Burma! with Errol Flynn. Zenas soon found out that his black listeners preferred Louis Jordan and Dinah Washington to Bing Crosby.

When he returned to Atlanta and his old radio station, he started to play $R \& B$ records in the morning. The boss arrived there a couple of hours later and never found out. But when the owner showed up a year later Zenas was immediately fired.

He landed at WGST in 1948 and started The Blues Caravan 
which was broadcast in the evenings and became the most influential show in the southern states.

He did live recordings and broadcastings from Atlanta's clubs and theaters, where Billy Wright was the king and Little Richard started getting heard. Billy later told me that Zenas had arranged Richard's contract with RCA. Zenas also became the manager for Chuck Willis and recorded him for Okeh Records in the WGST studio. Even Ray Charles recorded "I Got A Woman" there in 1954.

In 1954 the opportunity to buy his own radio station arrived. He called it WAOK. But there were no mistaking that his most proud memories was his collaboration with Dr Martin Luther King Jr. (1929-68). That's what Zenas rather talked about.

Zenas had gotten to know his father Martin Luther King Sr., one of the leading baptist pastors in Atlanta Georgia. In the beginning it was a pure professional collaboration when he arranged live broadcasts from his church; mostly on Sundays. Zenas also played a lot of gospel on the radio. He had met Martin Luther Jr. already as a teenager, without having a clue about his future greatness.

There was nothing particularly distinctive about him. He was indeed just an ordinary, fairly mediocre boy. I was really surprised when he led the bus boycott in Montgomery, Alabama. He had become a completely different person. It must have been a divine intervention. Actually the only person I've known that I could say that about. We had a lot of live broadcasts from the marches and demonstrations. 
Along with his partner, Zenas also owned a radio station in Montgomery, Alabama. It was the only local station to report what happened during the civil rights struggle. About $92 \%$ of all local radio listeners tuned in to the station during the march in Selma.

Besides, WAOK was the only station to report about the Coca Cola boycott by the black segment of the population. It was due to unfair wages to black workers at Coca Cola plants.

Our commitment to Dr. King made us lose many advertisers such as Coca Cola, but they came back later and then they spent three times more to take back lost customers.

He also became an outcast and called nigger lover by his neighbours and much of the white population.

Zenas said proudly that WAOK was the first radio station in America that described the living conditions and problems of the black population in half-minute-long editorials that expressed the station's opinions on race. They also had short radio spots about Black history.

The responsible person at present at the station had been Dr King's press secretary for three years. They also started local news broadcasts since the ghetto population had no interest or knowledge about what took place outside the city.

They encouraged all to register to vote; often in the form of contests with prices. The station owned a bus to pick up people who lacked money or initiative to go to the employment agency. 
There were thirty radio stations in Atlanta with surroundings and WAOK was the biggest with a share of circa 55\% of all listeners. Circa 55\% of the population is black but many listen only to gospel and spirituals played by religious stations. Only $5 \%$ of the advertisers are black.

Atlanta became Dr. Martin Luther King Jr.'s hometown and a natural center for the civil rights movement and the black student movement. It was also the hometown of Chuck Willis and Gladys Knight, Zenas said. Then Atlanta had been a small town but now it was growing by leap and bounds.

Zenas felt that Aretha Franklin had more feeling than James Brown who was more of a showman. In confidence he said that Aretha's father was a heavy drinker and that Aretha became pregnant as early as fourteen years old.

On Friday night I went to the Elks Club. It was located in the same 300 block on Auburn Avenue as the American Legion. Auburn Avenue was the main entertainment street of the black ghetto. There were a lot of people there, looking for a good time.

Elks was a tough club. At the entrance all guests were searched for guns or knives all the way down to the shoe shanks. This was the only club that summer doing this. But perhaps rightly so as Atlanta at this time had the highest murder rate in the USA.

The main attraction tonight was Lloyd Thunder who sang and played guitar with his own band. He had a bluesy, very powerful soul style all his own. He could be compared to Junior Wells as they sang in a similar way. But Lloyd was better. In fact, I think 
he was the best of all unknown soul artists I saw that summer. It is strange that I have never seen his name since then or a record with him.

He did among others: "You're Looking Good" (Wilson Pickett), “Slip Away” (Clarence Carter). And a long version of Otis Redding's “The Happy Song (Dum Dum)” that was brilliant.

It was a high pressure night. I was invited to dance by several local beauties. After a while I was invited to the table of $\mathrm{Mr}$ \& Mrs Carr. Soon Tommy Carr came back with the only other white guy in tow. He was my age but had no interest in music. He was there for the girls. Our conversation quickly died.

Saturday, July 6

I had been invited to the Carr family. They lived at 160 Northside Drive and had ten or twelve children. All the boys were in Vietnam. Left at home were six girls in the ages from five to sixteen years old. Christana (16), Ida (13), Florence, Pamela (10),

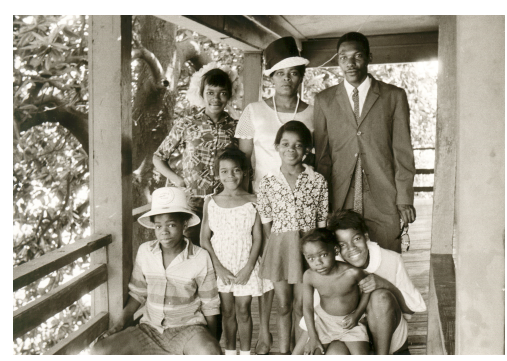

Tommy and Evelyn Carr and their six daughters gathered at the front porch.

Tomasene (8) and Tequila

(5). They lived on the first floor of a two-story building in a very run down but charming wooden building. At the ground floor another woman lived with her children. In the beginning this 
might have been a home for white workers or even an upper class family belonging to the cotton nobility.

In the middle of Carr's flat was a corridor and three to four rooms and kitchen were located at both sides. If a ball had been dropped to the floor it would have rolled with lightning speed to either side. So obliquely and twisted was this building and the floor.

Outside was an exterior porch.

Tommy had two day jobs as a truck driver. In his spare time he repaired TV sets and radios that people had thrown away.

Tommy's wife had lost a couple of front teeth - perhaps because of frequent pregnancies. She seemed tough, while Tommy made a milder impression.

He had been drinking pretty heavily the night before and was hungover today, so he rested.

They offered me food and the girls demonstrated some of the latest dance crazes like The James Brown, The Camelwalk, The Boogaloo and The Horse.

I don't think they'd had any white visitors in their home before. The girls were all excited about my blond and soft hair - and every once in a while sneaked up behind me, where I sat in the sofa, to feel for themselves. "Just like silk," they whispered.

The absent and distant uniformed boys’ photographs were lined up in the book case. 
This night I went to the American Legion. Sir Charles appeared there with his four-piece band. The place was full.

Charles was a very good singer who had grown up with gospel, and now specialized in fiery screaming. The show continued until three o'clock at night. I later bought a couple of fine 45s with him. These unknown Atlanta singers were very good.

Unfortunately it was too crowded to get a chance for interviews. But since then I have always had my eyes open for soul singers from Georgia. It is a trademark of the highest quality. From here comes James Brown, Otis Redding, Little Richard and Johnny Jones (Swanee Quintet), plus the fantastic Lee Moses, who recorded the fabulous "Bad Girl” (Musicor). He and Little Richard sang on Billy Wright's funeral. While Ray Charles grew up in northern Florida, he was born in Albany Georgia.

\section{Sunday, July 7}

At WAOK they recommended that I visit churches like Salem Baptist Church, Apostolic and Free For All Baptist Church at 1461 North Avenue NW plus of course Ebenezer Church on Auburn Avenue where Martin Luther King Sr. was pastor. But today Evelyn and Tommy Carr and I had decided to go to the big gospel gala. Before it I was invited to lunch. On the way to their house I walked past deserted lots near central Atlanta which only waited for the bulldozers and shovels.

From a modest small one-store white/grey wooden building I could hear wonderful gospel singing only accompanied by hand clapping and tambourine. Nothing distinguished the building as 
a church. I didn't dare to go in and disturb the proceedings. There were probably only room for twenty-five people inside.

They had prepared a feast in the Carr residence. It was chicken, fish, vegetables and they proudly showed me several full freezers that Tommy had repaired.

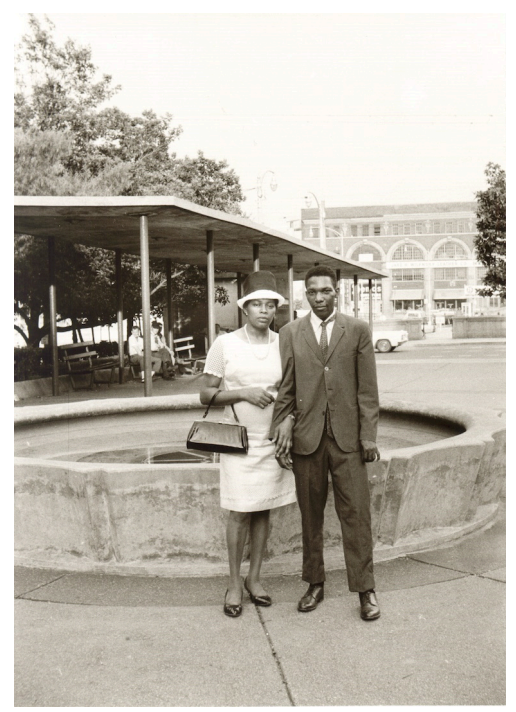

Evelyn and Tommy Carr, after Sunday's Gospel Show

The gospel show at the auditorium opened at three o'clock in the afternoon and we arrived a few minutes before. It was pretty full and we only got seats far from the stage.

The Soul Searchers from Atlanta opened (A fine seven men group with strong singing).

A white man in his thirties was hit by euphoria and started running around and around. The hall had plenty of room at the sides and in the middle and could probably be used for indoor track athletics. It also gave the nurses good access to examine those who had fainted or had seizures that looked epileptic.

Next were the (five) Blind Boys of Alabama. They did not enter the stage in such a striking manner as in Sweden some fifteen years ago, when the seeing guitarist walk in first and in 
a line after him the blind men walked grabbing the coattails or shoulders of the one in front of them. (Like a limping Brownie McGhee, with the guitar, led the blind Sonny Terry blowing the harmonica.) Clarence Fountain, lead singer with the Blind Boys of Alabama, had left the group temporarily to try a solo career. He performed by himself when appearing in Harlem, New York in August.

The Blind Boys of Alabama did a good job that day. But it was surprising that they, thirty years later, were the world's leading group alongside the Dixie Hummingbirds. There were in fact better groups in Atlanta this afternoon.

The duo next was presented as Mr \& Mrs Pugh from Miami Florida. Perhaps better known as the Consolers. They sang a low-key but very suggestive form of gospel music. It sounded very authentic and down to earth. I was surprised that it was so appreciated, especially among the older members of the audience, as I myself prefer the hard quartet gospel of the 1950s. The white clad nurses had to take care of several patients who were hit by the Holy Spirit and lay floundering. Mr \& Mrs Pugh sounded very rural, a bit like the country and western pioneers Carter Family or the Staple Singers.

Rev. William Haynes \& The Augusta Jubilee Singers

Unfortunately Reverend Haynes got hold of the solo microphone when the Augusta Jubilee Singers had gotten up steam and the audience were with them. He calmed the people down with his preaching and singing. These interruptions disturbed me and an 
otherwise excellent group. What else but excellence can you expect from a group from Augusta, James Brown's hometown?

The Nightingales from Chicago however, didn't stop when they had the audience with them. The group was no longer led by the legendary Julius Cheeks who had left the group in the early 1960s. They accelerated from the start and people danced or ran around the hall or just sat in the benches shaking and screaming. Fantastic!

Cleophus Robinson did a sophisticated appearance with his son. He was elegantly dressed in a full length long cloak and was accompanied by a peaceful piano playing. Gospel crooning maybe, but many listened closely and answered back with "Tell the truth!" and "Amen!"

Shirley Caesar, with white clothes, stood in front of seven to eight background singers and was accompanied by piano and drums. A couple of years earlier she had left the Caravans and was now appearing as an evangelist with her own group. When she preached during the performance it was fully integrated. This was probably the high point of the day. She was a wonderful singer; very skillful, melodic and intense and she didn't have to only scream to get the massage through. That is appreciated after a couple of hours of very hard gospel. She also danced around and most gracefully too. The only weak spot was her drummer who played too loud and was disturbing. It was enough for me with a guitar or piano. Hand clapping can swing better than drums.

In the foyer records were on sale with the visiting artists both 
before and after the show. I picked up a copy of the magazine Gospel News Journal and later became a subscriber.

Afterwards the Carrs and I walked around in the center among government buildings. Unfortunately many locals feel that you're interested in modern buildings while you just want to dig deeper into the bluesier slums.

I was back at the hotel at nine o'clock pm. It was an early night. In the middle of the night I was awakened by a fire only 100 meters away. The fire station was only another block away. There were a lot of fires in Atlanta. Every night the fire trucks pulled out with full sirens about one to two times. The city center was to be renovated. There were probably lots of buildings to be torn down that were set on fire to speed up the process. Night sleep was often disturbed.

When I lived close to a fire station in Stockholm sirens were heard only one to two times per week and not several times a day like in Atlanta.

Monday, July 8

I had heard that James Brown was in town and went to WAOK to investigate. But it was false. Eddie Braddock was there. He was a Chess promotion man.

Nothing much happened in Atlanta on a Monday night. I was going to see LaVern Baker at a fashionable night club in the center of town. It might have been The Kittens Corner, a white club at 8th and Peachtree. But I never wrote anything about this night in my diary. LaVern had been there during the week I was 
in Atlanta and would be relieved by the Shirelles a couple of days later for a week long engagement.

At the entrance door all guests not wearing a suit and tie had to rent a sort of imitation costume plus tie. Dressed in this I took a table close to the stage. Maybe the rights to serve liquor depended on the guests' clothes? Soon LaVern appeared in a vulgar white wig. But where were the accompanying musicians?

I had been sipping Georgia Peach Wine while writing letters home at the hotel. The liquor stores often had attractive prices on this type of drink. This brand had become a favourite of mine. Despite slightly diminished cognitive functions I at last realized that LaVern had changed career. She had become a stand-up comedian.

I was sitting here with a group of middle-aged businessmen and traveling salesmen in real or phoney costumes and was forced to listen to tasteless jokes.

The entrance fee was at least double compared to the dollar that The Elks or The American Legion had charged. I became more and more dissatisfied the longer the show went on. I had not found other black comedians who were that funny either, except Dick Gregory (Black Dick for President), Redd Foxx and Pigmeat Markham. LaVern Baker was entertaining a prejudiced white audience at a place where black power, afro hair and Black Panthers were shunned. I became more and more upset.

I knocked on her dressing room afterwards. Perhaps with the intention to interview her. But I was so frustrated that I instead 
told her how disappointed I was. I had heard a few of her hits like "Jim Dandy" and "Bumble Bee" - the latter was called “El Moscardon” on a Spanish made EP. But I didn’t really understand that she was number two in the female $R \& B$ hierarchy of the 1950s after Ruth Brown.

I have to take my share of the responsibility that LaVern later moved to the Philippines, where she worked for the US Army. It cannot be pleasant to hear that you have disappointed your audience as much as I told her. Or maybe I scared her back into the record business. She recorded an album on Brunswick shortly afterwards.

I went straight back to Auburn Avenue and ended up in the basement below the Elks club with a bunch of musicians that I had seen at the Elks and the American Legion. I needed to calm my nerves after the ordeal with LaVern Baker. We talked and drank until the wee wee hours. I especially remember an old saxophonist with a face as wrinkled as Duke Ellington. He had been active in Atlanta's R\&B scene during the 1940s and 1950s. But most of what was said was quickly forgotten as this gang almost succeeded to drink me under the table.

Going home I got lost a couple of times. I always had a map, but now I held it upside down...I was happily unaware that the number of active and potential killers were higher here around the Auburn Avenue than elsewhere in USA. Arriving very late, I had to tell the nice cleaning lady who awoke me after a couple of hours to come later. She always brought had her young son to work. 
I heard a lot of gospel songs on the radio in Atlanta and some New Orleans hits too:

"I Could Never Love Another"-Temptations "Who Want Me Now”-Tokay Lewis? “America Is My Home” - James Brown "Working On A Groovy Thing”-Patti Drew "Nite Owl” - Howard Tate "I'll Never Do You Wrong”- Joe Tex "We Shall Overcome”-Hudson? Chorale "Jesus, We'll Fix It”-Traveling Tones “Come See About Me”-Gray’s Gospel Singers "Been A Great Change” - James Cleveland "Comfort Me" - Shirley Caesar "IFeel The Spirit”-Meditation Singers “Don't Be afraid, WalkOn”Shirley Caesar "Let It Happen”- James Cleveland "If You Would Be Down”-Dynamics “The Love Of God” - The Soul Stirrers “You Better Check on Your Way Of Lovin”the (Dixie Humming-)Birds "Precious Lord" - Aretha Franklin "The Day Is Passed And Gone" - Aretha Franklin "IDon't Know What This World is Coming To" Sly \& The Family Stone "I've Got To Get Myself Together" -Big Denise “Funky Walk \& Horse”-Fantastic Johnny C “Air Force Shuffle” “Thank You John”-Willie Tee “Lovers Holiday”-Peggy Scott \& Jo Jo Benson "Stop” - Betty Lavette "I'm Without A Girl” - the Mighty Marvelows "I Thank You”-Diana "You Got Everything I Need” - Freddie Scott “Got To Have You” Fantastic Four "You Know I Love You" -

Fabulations? "Coo Coo Over You" -The Hueys "Hypnotised”-Linda Jones "I Who Have Nothing”-Little Milton "God Is Standing By" - the Soul Stirrers 
Tuesday, July 9

The nightlife in Atlanta was most active during the weekends. I had nothing planned this night but to go to the Carr's and thank them for the hospitality. They had been very friendly despite our different backgrounds.

They were seated in front of the TV watching a Country and Western show. Just as on Saturday night when I left. James Brown had appeared on another channel just before I arrived, they told me. The dominance of James Brown was now almost unbelievable. He was heard everywhere. On the radio he called for moderation, to keep the summer cold and go back to school. All stations played two to three of his records every hour. He released new records more often than anybody else. In the clubs there was an unwritten rule that every tenth song had to be by James Brown.

Wednesday, July 10

The flight to Miami was booked at 7:30 pm. While waiting I went to the movies. I had seen long queues outside a theater nearby while walking to and from the hotel. The audiences leaving the cinema seemed quite pleased. They showed Rosemary's Baby, not yet shown in Sweden.

Then the planes to Miami were quite often hijacked and ended up in Cuba. (There were no lines to Cuba because of the embargo.) Later they were flown back leaving the people who wanted to stay. This trip through Florida was without problems, 
despite a tropical thunderstorm with lots of lightning flashing by on both sides of the plane.

Meanwhile I reflected about my stay in Atlanta. It was a nice town with lots of friendly and hospitable people. The longer you were in the south, the better it became. There was a welldefined entertainment district with talent from all over Georgia. But I had not met anyone from the record business. I can only speculate why I didn’t look up Phil Walden. (Was his office still in Macon?) A few years before he had booked lots of soul stars on the rise. An old leaflet had pictures of Prince Conley, Al “TNT” Braggs and Billy Young and many others, then unknown to me.

Phil's career went straight up. He became an important man in politics and in the circle around president Carter. But no one at WAOK or elsewhere had directed me to him. So I guess that his interest in aspiring soul stars had faded. There were no local record companies of importance, except maybe Peachtree Records at 431 Glen Iris Drive NE, where Johnny Jones and The King Casuals recorded.

I never went there. All these fine Georgia singers probably had difficulty securing a recording contract locally. If I was working as a talent scout in the south I would certainly look in Atlanta.

Unfortunately I never got a chance to see Clarence Carter; one of the best new soul artists. He was then appearing in a country club circa 25 miles from town between $9.30 \mathrm{pm}$ and 1.30 at night. It was too far to go and no buses back at night. The name of the club was Lithoma or Lithornia. Or was the club located in 
$168 \cdot$ JONAS BERNHOLM

Lathemtown, north of Atlanta? Or was it located by Lake Lanier northeast of Atlanta? I guess I will never find out. 


\section{Miami}

July $10-15,1968$

Wednesday, July 10

Darkness had descended on Miami and I took a room in the first cheap hotel I could find. I think it was called the Capitol Hotel (at Miami Ave/3rd St. NE), and it only cost $\$ 8$ a week. The room had no windows, but a shutter in the ceiling. Tonight it rained and was quite cool outside, but the next day I understood why it was so cheap. It faced a paved parking lot and when the sun was shining on the roof, it became hot as an oven, and it was impossible to get even a breath of fresh air. Cockroaches and insects enjoyed this subtropical atmosphere and multiplied.

Thursday, July 11

Posters of James Brown's recent big concert at the Miami Stadium could still be seen on the town. It had taken place just a few days before, and the package was announced as a "show for the entire family." 
My first stop was Miami's leading soul station WAME at 777 NW 54th Street. My contact was Butterball - I think his real name was Milton Smith - but he was busy and I talked with the program director Lee Wilson instead. He had fifteen years of experience in the radio industry, and he had crossed over to $\mathrm{R} \& \mathrm{~B}$ and the soul stations after seeing Sam \& Dave in 1963. He told me that there were fourteen radio stations in Miami and this was number two in popularity. They played only soul and no pop or blue-eyed soul. Their listeners only wanted black artists and not even the Righteous Brothers were let loose on the air. Five DJs worked here plus a gospel DJ. Every week 300 new soul singles came to their mailbox. Out of these they chose 10-12 songs to the current Top 40 list that they printed in 15,000 copies and distributed to record stores and listeners. Each DJ could also play three songs each day of their own choice that was not on the station's playlist. A blind DJ featured six hours of gospel music every day (between 5 and 7 am and 7 to $11 \mathrm{pm}$ ).

They did not take part in politics and their editorials were only about non-political issues such as if garbage was not collected and taken away.

In Miami, $15 \%$ of the population was coloured, while more than $90 \%$ of the advertisers were white. And there was also a fastgrowing Spanish-speaking population here. But they had their own radio stations. The salary of a DJ was around \$150-200 per week while the highest paid earned $\$ 400$.

Lee said that the best vocal groups in Miami were the male Movers and the female Marwels (also spelled Marvels and later 
renamed the Fabulettes). He also recommended female singer Betty Wright.

The best Miami singers were Frank Williams \& The Rocketeers, Freddy Scott and Benny Latimore.

He also recommended that I see Vivian Reed, who was in town, and Stevie Wonder who was performing at Harry's American Showroom (on 9, 10 and 12 July).

Other local artists, recommended by the industry-people later, were Lavel Hardy, Reflections (with the song "I Need Your Love”), and Ella Washington. Recommended clubs were the Double Discoteque and Soul's Place at 2nd Ave and 36th Street, NW.

On WAME I met Ska music promoter Alty East. When he realized that I planned to meet everyone in the soul music industry in Miami, he gave me a stack of leaflets to distribute and drove me to Tone Distributors located at 495 S. E. 10 Court, Hialeah. Lee Wilson had also recommended this place. There I should see Henry Stone, Milt Oshuns and Brad Shapiro.

The office and the warehouse was located in a modern industrial area. Present were Milt Oshuns, Clarence Reid, Henry Stone and office and warehouse personnel. During a sightseeing tour I was taken to a small room without air conditioning. On the floor sat the white southern group called the 31st of February. I received a 45 with the group. I did not like their music.

I was told that Tone Distributors was actually the largest in the United States. In 1955 they had started a studio for demo 
recordings, and there they had recently produced Betty Wright Girls Can't Do What Guys Can, released on the Alston Records, distributed by Atlantic. Her name was often mentioned in Miami. All were impressed by her youth and intelligence.

Here King Coleman recorded the original "Mashed Potatoes," backed by members of the James Brown Orchestra. The Night Crawlers recorded “Little Black Egg," leased to Kapp. It was a hit four years ago.

On the Dade label, Benny Latimore recently had quite a success with "The Power And The Glory." His name was mentioned with great respect and as I had never heard him before they played this record. He was certainly a very good singer, but still not in the class of Bobby Bland with the Joe Scott Orchestra.

Freddy Scott and the Four Steps on Marlin Records were not the same Freddy Scott who recorded on Shout Records and was produced by Bert Berns.

Miami's most famous soul studio was however The Criteria Recording Studios on NE 149 St and there was also the Tropical Recording Studios at 50th St. and 7th Ave. But I never visited these two.

Steve Alaimo was one of the producers at Tone. He was perhaps best known for his own hits like "Everyday I Have To Cry" (Checker Records). He was a pioneer blue-eyed soul artist, or simply accepted as white. He had recorded in Nashville. Another producer was Brad (ley) Shapiro.

But Henry Stone was the veteran and senior producer here. In 
the 1950s he had worked at King Records with Hank Ballard, Little Willie John, Otis Williams and others. He was the head of the Tone operation and seemed to be around 55 years of age.

A skinny, intense young man introduced himself as Clarence Reid. He worked as a songwriter, producer and singer. He was born in Cochran (near Macon), Georgia in 1943. Between 1953 and 1955, he sang lead in the Holly Grow Baptist Church Choir. Then the family moved to Miami and he began to sing R\&B. In 1960 he recorded "The Big Sound” on Dade and in 1961 "Down With It" and “Can’t Quit It” on Selma Records. It became a hit that Chess distributed. In 1962, he came to Dial and recorded "I Didn’t Got All Your Love But I Got My Share,” another hit. But he left Dial because he and Joe Tex, who also was on Dial, had similar styles and the company put most resources on Joe. Next stop was Wand Records (1963) where he recorded "I Refuse To Give Up” and "Weak In My Knees.” In 1967, he came to Phil L.A. of Soul (perhaps best known for their recordings with Fantastic Johnny C. He made "Cadillac Annie” (a "Mustang Sally” clone) and "Tired Blood.” His latest was "Instant Love” / "Love Song” at the R. E. label.

But mostly, he had worked with songwriting and producing. He composed for Sam \& Dave during their Roulette period ("Have No Fear") and for Helen Smith - "Woman Will Do Wrong” (Phil L.A. of Soul). He wrote the Big Maybelle soul classic "Don't Pass Me By" and produced her album Queen Mother of the Soul, (including the cover version of the classic "96 Tears"), but Bob Gallo got all the credit on the cover because Clarence was not contracted to Rojac Records. At that time Gallo and 
Reid worked together in The Incredible Sound Studio located between Times Square and 42nd street in New York. He was also involved in Gary U.S. Bonds Quarter to Three.

He cited Hank Ballard, Joe Tex and Chuck Jackson - all the way back to the time of the Del-Vikings - as his vocal influences. Henry Stone had taught him how to produce records.

Clarence had also written songs with Steve Alaimo.

Clarence was fond of English 1960s pop. Among his favourites were Dusty Springfield's “You Don’t Have To Say You Love Me,” Gerry \& the Pacemakers' “Don't Let The Sun Catch You Crying,” Beatles' “This Boy,” Rolling Stones' “Get off My Cloud,” for example. He had always wanted to travel to Europe.

Clarence Reid (1939-2016) was certainly very competent, but neither his LP, which was released a year later, Dancin' With Nobody But You Babe, and his singles on Dial or Phil L.A. of Soul were extraordinary. That summarized much of what was done at Tone in Miami. It was good music made by skilled craftsmen but lacking the qualities required to become immortal. Their main strength was perhaps the access to good distribution. (Today Clarence's recordings as Blowfly are highly appreciated by connoisseurs of risqué and dirty records.)

Henry Stone appeared to be quite busy, and I never got time to interview him. My knowledge of 1940s and 1950s R\&B was then inadequate. We just shook hands and exchanged a few pleasantries. When the opportunity arose, I met him in the parking lot next to his Cadillac. He had a big after-work drink 
with ice in his hand, and excused himself; he was on his way to fetch his wife.

Later, I have many times seen Henry Stone's name on various King records. He belongs to the elite of producers and recording industries personalities, that were able to create many immortal $\mathrm{R} \& \mathrm{~B}$ master pieces with a limited budget and time.

"The Twist" with Hank Ballard \& The Midnighters - is a flawless masterpiece and one of the best R\&B songs from the late 1950s. (But in Europe we only heard Chubby Checkers cover.) Otis Williams and the Charms (Heart Of Stone), and songs by Little Willie John bears his signature. Henry also had the Rockin' label that released Wilbert Harrison's minor-key Letter Edged In Black.

Alston Records were distributed by Atlantic, but I think that Henry was also negotiating with Jerry Wexler (Atlantic Records) at this time. It resulted in Atlantic later starting recording in Miami, too.

I went to WMBM and met white program director Donny Gee, who proudly showed his new sports car parked outside. He had left the studio after putting a longer song on the turntable. He didn't seem worried that the record would end and silence fill the air.

The station was located at 814 1st Street in Miami Beach. I asked him (without considering his new car) how much a DJ earned. He repeated the \$150-200 per week that Lee Wilson had said. 
The highest paid could earn \$400. That's what a DJ in New York made.

WMBM was a small station, and they only got 200 new singles in the mailbox every week. They had 49 songs on the playinglist, plus a station favourite. They brought in six new entries on the list every week - not based on audience response but what the radio industry reported and what was played in other regions. They also printed a playing list and distributed it to record shops. (I guess costs were divided between record labels, record stores, advertisers and the radio station.)

They played two hours of gospel every morning and six hours every Sunday. The DJs were not able to select their favourites. Everything was determined by the program director, Donny Gee. They didn't actively support the civil rights movement but sometimes took a stand in an editorial.

New entries in my notebook were Campus Record Distributors, 7250 NW 36 AVE. Joey Stanzione and Eddie Lambert worked there. Other nightclubs were Foxes Den, Knight Beat, Island Club, Continental, Harlem Garden, the Cotton Club (Joe Walker, Brother Ray ph: 7575704). 


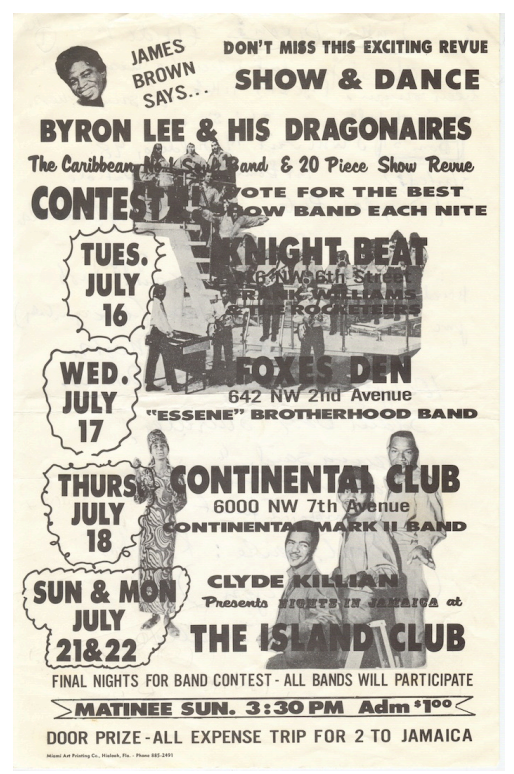

Club listings in Miami
In the evening I went to the Continental Club, which was located at 6000 NW 7th Ave/ 60th Street. On stage that evening was singing group The Reflections and the soul band Mark \& The Ar-Kays. Their choice of name indicated that they wanted to be associated with the MarKeys or the Bar-Kays.

They did mostly soul classics like:

"I Got The Feeling” (James Brown) “Tighten up” (Archie Bell) “It’s A Man’s World” (James Brown) "Funky Walk” (Dyke \& Blazers) "Soul Serenade” (Willie Mitchell/King Curtis) "Mustang Sally" (Wilson Pickett) "In The Midnight Hour" (Wilson Pickett) “I'm Not Tired” (Wilson Pickett) "Funky Broadway" (Dyke \& The Blazers/Wilson Pickett) “Something’s Wrong With My Baby” (Sam \& Dave) “Soul Finger"(Bar-Kays)

Mark McIver was the lead singer and guitarist, and he was backed up by Melvin Gunby (bass), Walter Blue (drums), Bennie Bailey (Baley?) (saxophone), Robert Blowt (trumpet) and trombonist “Earvin.” The band's leader and frontman Mark McIver was born on 8 September 1944 in Jacksonville, Georgia. His gospel background was in the Silver Tones (not to be confused with the legendary Swan Silvertones) which he left 
in the early 1960s. He played several instruments - saxophone, drums and guitar on stage - but he preferred the bass. His brother John McIver played with Freddy Scott (the local recording artist and drummer). John had recently visited Stax in Memphis, but without getting a job or a record deal. For some reason, Mark thought that his brother's success (?!) at Stax would also pave the way for his own career. People would soon discover that John had learned everything from Mark - and so his luck was made. I never understood this connection. Mark was a very optimistic young man, but seemed confused. He needed more than a repertoire of soul classics - where the original artists were still alive and well and appeared regularly in the region in order to break through in the way he imagined. His current record "Soul Thing” / “Kick Of The Clock” (Dade Records) was produced by Henry Stone.

The owner of the Continental Club was Willie Walters (6011 NW 7th Ave). But this evening he had taken another role namely, as a producer and manager of the vocal group The Reflections. They had modelled their style on the Impressions and the Temptations, like hundreds of other groups across the United States. (Another Reflections group, on Golden World Records, had recorded “Just Like Romeo \& Juliet” which even entered the Top Ten in Sweden.)

It was odd that so many Miami artists used or chose names that was already occupied by others. (Freddy Scott, Reflections, ArKays and later the Fabulettes.)

The Miami Reflections were 
Ira McCall (lead) 22 years, and he wrote the group’s material.

Albert Turner (bass) 22 years,

Rosevelt Hubbert (first tenor) 20,

Earl Brown (second tenor) was 21 years old.

All came from Miami and had sung in various gospel groups and then together for four years. The Reflections performed locally in Miami and made occasional detours to small places in Florida. Their first record was released on WENT: "You Don't Love Me" / “I Need Your Love (To See Me Through).” Willie Walters trod restlessly around in the room during their performance and then did his best to teach the group how to perform. There was much to say because the group was not ready for the big league yet. Both the singing and choreography could be much improved as well as their timing. But "You Don’t Love Me” was quite good perhaps because this was the only song that had been rehearsed until it was perfect. (They also performed the B-side "I Need Your Love To See Me Through.”)

Other songs they did were: "I Never Found A Girl" (Eddie Floyd), “I’ve Been Trying” (Impressions) which they did in an interesting falsetto vocal arrangements, "I Could Never Love Another.”

Willie told me that the group had used Criteria Recording Studios for their recordings.

Friday, July 12

It was difficult to travel by local buses in USA. The night before it took a long time to find one and get home. Timetables as well 
as a route descriptions were usually missing. This day, I took the wrong bus and then most of the day was spent waiting in the hot sun before finding the right one. It was exhausting. Finally, back at the hotel, I then walked both back and forth to the Continental Club, to be sure. Vivian Reed was performing there on July 12-13. It was a crowded and a very busy night. High expectation was in the air. Her stage show included: "Sunny," "Let It Be Me" and of course her current hit "Yours Until Tomorrow."

And she also sang a jazz song in the style of Sarah Vaughan. She established good contact with the audience and was well received. Her vocal style and choice of material was not unlike that of Holly Maxwell in Chicago. (Both had classical, opera training which is well suited to Broadway musical performances.) Vivian was the better artist but Holly was actually not far behind.

I talked to her after the show. It was her first tour of the South, and she traveled with a friend.

Vivian was born in 1945 in Pittsburgh, Pennsylvania. She now lived in New York. She began singing early - already at two years of age - and quickly became a solo singer in Good Hope Baptist Church Choir. But at the age of thirteen, she crossed over to classical music. For several years she studied and sang nothing but the opera in a musical institution. High School diploma was received in 1963 in Pittsburgh and then she went to New York and the Juilliard Music School for further training in classical music. She also studied violin and piano. But before graduation, she dropped out and began singing R\&B and pop. Today, her style was "New York Soul” - sophisticated, well- 
produced and written, and performed with a lot of feeling that can be enjoyed by a wide audience. Aretha Franklin and Sarah Vaughan were her favourites.

In early 1968, she had been signed to Epic Records and "Yours Until Tomorrow" had just entered the Hot 100, and was her first hit. Songwriters were the veterans Goffin - King. The song had previously been used on a B-side for Dionne's sister Dee Dee Warwick. (Dee Dee did better soul-recordings than her more renowned sister. But mostly, she was singing in the background of numerous soul recordings made in New York.) Her producer was Ted Cooper and officially "Yours Until Tomorrow" was her first record. But Vivian told me that she had made a record under another name when that artist had lost her voice. But she wanted to forget this recording and named neither name, title or company.

Her manager was dancer Honi Coles, legendary Master of Ceremonies at the Apollo. The theater was also a natural first stop in her quest for stardom. She had been launched there when I left New York. Bill Cosby topped that bill, as a singer. Six weeks after Miami, in the crowded foyer of the Apollo Theatre, I got a friendly pat on the back, turned around and there stood Vivian. Undeniably an honour for me to be recognized in a crowded place, by such a stunning beauty and a world artist to be.

She released the Epic LP Yours Until Tomorrow and her career went straight up. She became a major star on Broadway (Bubbling Brown Sugar gave her a Tony Award) and the French people called her "Mademoiselle 100,000 Volts." My own 
favourite song by Vivian was the B-side Mama Open The Door (Epic). This is deep soul of the highest class but otherwise she mostly recorded lightweight material.

Sheryl Robinson was opening act tonight, and proved to be an excellent Aretha Franklin inspired singer.

Then JoJo “Big Big Soul” Danes took took place on stage. He was also called “300 pounds of soul” and sang "I Can't Turn You Loose,” “I Who Have Nothing,” “My Girl,” and "I’ve Been Loving You Too Long.”

It had been an evening of very good music.

Saturday, July 13

During the day I went to Miami Beach and strolled around on the beach. But swimming - and leave valuables on the beach was not an issue.

There were rumours about a soul show tonight at the Foxes Den (642 NW 2nd Ave/7th St), but there was no advertisement outside. The club seemed closed for the night, except that the door was open. I walked inside and was let in for free into the almost empty hall. Present was a very dynamic soul-package administered by Luther Dixon. This bunch of very interesting artists were led by New Orleans Soul queen Betty Harris. Johnny Jones, the former lead singer with the gospel group Swanee Quintet, tried his wings as a soul singer. I had not heard about the Swamp People before. 
This could be a very memorable evening. Betty Harris had actually done better New Orleans soul recordings than Irma Thomas. Her songs had been featured on British LP Series Bell's Cellar of Soul: "What Did I Do Wrong," "What a Feeling Sad,” “Can’t Last Much Longer," "Nearer To You.”

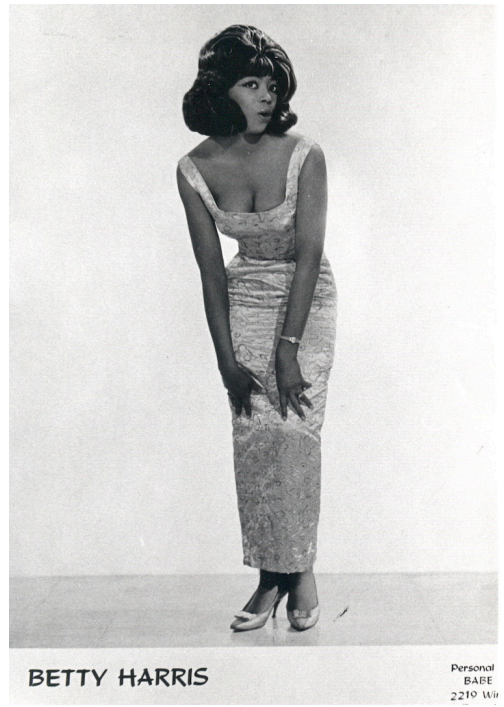

Before the show I had a chat Betty Harris promotional photo with her. During her more than ten-year career, she had toured across the United States and performed at many Rock \& Roll and television shows. Luther Dixon was her promoter at present.

She was born in Orlando, Florida in 1940, and sang gospel music at the age of sixteen. Then she started with $R \& B$ when she realized that in gospel, she would just work a few days a week. Then her family moved to New York. In 1958 she became a member of the girl group The Hearts where Baby Washington was another well known singer to be. (Baby W. has made many fine recordings and an odd classic.) At this time they worked maybe three nights a week so Betty took a day job as a secretary for a promoter. They released circa four records and had a decent success with "Lonely Nights," and was out touring for six months. In 1960, she left the group and began singing 
solo. In 1963 she toured and worked with Otis Redding. Then Bert Berns discovered this diamond in the rough. He produced "Cry To Me," which was released on the Jubilee label. (Bert Berns was one of the greatest producers of the early 1960s.) Solomon Burke had already recorded it but Betty Harris version sold better and reached the Top 10 while Solomon stayed in the Top 30. (In Billboard's Hot 100, Betty reaches No. 23 while Solomon No. 44 - it was undeniably an achievement to defeat the masterful soul singer on his home turf.)

In 1964 she stopped singing. She thought that everything was going too fast, and that she had lost herself.

After a couple of years, Sansu and Allen Toussaint made her reconsider this decision. At Sansu she really made soul fans happy with classic recordings like the aforementioned plus "Mean Man" and "Ride Your Pony." She recorded a total of circa ten $45 \mathrm{~s}$ at Sansu. But the New Orleans soul sound of the 1960s was really one man's work - Allen Toussaint. "He dictated every moan, scream and ooh - aah, I sang. He is a genius but I would have liked to have a bit more freedom,” said Betty. She even disliked her current record ("Ride Your Pony”). Betty was not at all happy with it and she saw Lee Dorsey's work with Toussaint as gimmick oriented. His singing had only one purpose only - to accentuate the beat. Allen Toussaint was the one behind it.

Betty was undeniably straightforward when it came to Allen and his work. She did not have much more to say about her recordings, except that she simply forgot about those that did not sell. 
In my opinion she's the Billie Holiday of soul singing. The records have an ominous feel and atmosphere and stunning arrangements and accompaniment. I don't think she was aware how high we European soul fans held those recordings. But she said she would love to come to Europe on tour.

In retrospect, Betty Harris did not make much noise in soul music after leaving Allen Toussaint. Her career might have some parallels with James Carr. They seem to have had the same ability to express the deepest feelings of despair and resignation, but may unfortunately not always have been able to meet everyday life. She was probably more complex than this brief encounter could show.

She said that she had learned early to take care of and support herself. She was not ashamed to try different things. She had been working in a beauty salon as a model when she was not touring. Her hobby was swimming. She had had her own show in Miami Beach singing musical songs and show-tunes, from the Hello Dolly musical, for example. She was certainly no stranger to sing in different styles and joked that next time it was gonna be hillbilly music.

She strove for independence and freedom of expression but seemed a little depressed and mentally fragile now. She was both frank and forward but did not have the big ego needed in the music industry. Spontaneously, she told me that she could hypnotize herself before a show so she was totally involved in the song and did not notice the crowd. (Perhaps not the best way to connect with the audience.) Betty Harris was not really a great stage performer this evening. She seemed a bit shy on stage and 
her mood was melancholy. It did not really meet the expectations I had for this great soul queen. But, I guess very few saw her live in the 1960s. I'm happy to be one of the few Europeans that did.

No one can deny that Betty had the honour of having participated in some of the most emotionally charged and heaviest soul ballads in music history.

Her show consisted of the following songs: "Cry To Me," "In The Midnight Hour," "Hold On I'm Coming," "Stormy Monday.”

It was a rather strange mix, and not a trace of her masterpieces at Sansu. Her singing was first class but the accompaniment still left much to desired. And she had to sing covers ...

In 1974 in Montreux, Art Neville (of the Meters) told me that Betty was working in a department store in Texas - perhaps at the perfume counter.

Luther Dixon was born in Jacksonville, Florida in 1931, and was a well-known and highly respected name in the record industry. His track record consists of compositions like:

"Boys," "Soldier Boy" and "Mama Said” (The Shirelles) "Soul Serenade” (King Curtis, Willie Mitchell) "100 pounds of Clay” (Gene McDaniels) “16 Candles” (Crests) "Love You 1000 Times” (Platters) “Human” (Tommy Hunt).

Luther also mentioned "Just Born (To Be Your Baby)," a hit with Perry Como and "Why Baby Why" with Pat Boone, and many others. 
He had been married to Inez Foxx (the female half of the sibling duo Inez and Charlie Foxx) - but now they had separated. He and Inez were too busy with their careers to have a chance to meet, said Luther.

He enlisted in the army and went to Japan in 1946. He had to lie about his age (he said that he was seventeen) to get there. He was not interested in fighting, but to study Eastern religions. In 1948 he was back in the US.

Luther had retained his interest in religion (Buddhism, which he came in contact with in Japan, and even yoga), and he believes in the Essenes Brotherhood - he presented it as a form of African religion. Essenes were a group of people who lived in Palestine around the birth of Jesus and Jesus is believed by some scholars to have been influenced by their thinking. (Luther called his band the Essenes Brotherhood. They backed the stars this evening.)

When he came back to USA, he began singing with three other young men. They called themselves the Four Buddies and had a hit with the song "I Will Wait." He also had a brief boxing career at this time. Then he started a solo career as a singer and recorded "Feeling Of Love" (Chess).

Betty Harris, who sat behind the stage in the same room interrupted Luther and said she could not believe her ears. "Luther, a R\&B singer ??! Unbelievable!”

She said that the night before Luther had almost driven her crazy by trying to sing a duet with her. She had made him 
promise never to try it again! (I don't find Luther's solo effort on “Feeling Of Love” very impressive either.)

He began composing full time around 1950-51. He achieved great success even though it took a few years to break through with songs like Chuck Jackson's first bestseller “I Don’t Wanna Cry” and “Angel Child” for Nat King Cole and "Bahama Mama” for the Four Aces. He tried to self publish them on Ludix, Belinda, and the Scepter publishing companies. His Ludix Publishing office was located at 422 Madison Avenue in New York.

Around 1958-59 he started working as a producer and on the merit list are 16 Candles (The Crests). He also started the record label Scepter.

Since six months he had been working as a promoter for the evening's performers. Luther also mentioned an eight-man group called the Blue Notes from Newport - (with four singers and four backing musicians). He called them a very hot group - I guess he meant later superstars Harold Melvin and the Blue Notes.

Johnny Jones had launched "Tennessee Waltz" on Bobby Robinson's Fury label this summer. He was born December 28, 1938 in Augusta, Georgia. Until then he had been lead singer with the incomparable gospel group The Swanee Quintet for no less than twelve years. They had released four LPs. He had left the group a few months earlier. In the early 1950s, he had sung and toured with several other gospel groups. "Augusta, Georgia” 
has always had a special place in my heart. Not because of the golf course, but because James Brown grew up here.

James took an interest in the group and they were on his package shows. He even produced a fine gospel music version of his own million seller “Try Me” - in a slightly disguised version called "Try Me Father” with the Swanee Quintet. Their biggest sellers were "Sleep On Mother," “There's Not A Friend Like Jesus” and "Over Yonder.” There are many LPs on Nashboro and Creed with them. One of my favourite songs is "Silver and Gold." The Swanee Quintet is one of the best gospel groups of all time. Why James Brown liked them is obvious.

It was also obvious that Johnny Jones came directly from gospel and the church, and had not really prepared himself for a life as a solo artist or had time to acquire a repertoire of his own. The track selection left a lot to be desired.

“Tennessee Waltz,” “It's Alright” (Impressions-Curtis Mayfield), “Down By The Riverside,” “Amen,” “If I Had a Hammer.”

In addition to his current hit, it was folk-gospel standards. But he was great. He gave a pure gospel music performances with his unique gospel falsetto yodelling that was jaw dropping and gave me goosebumps.

I had not heard about Al \& Jackie - The Swamp People - before. Jackie Porter was born in Atlanta in 1940 and began singing gospel music in church at the age of eight. In 1957 she joined the Gospel Harmonettes where she sang for three years and left 
before a nationwide tour. She had already been singing R\&B in the weeks and gospel on Sundays. Peacock recorded her in 1960, "Why Not Give Me A Chance,” which went unheeded. In 1963, she came to New York.

$\mathrm{Al}$ (Bertus) was born in South Carolina in 1941. He sang gospel music there until he came to New York in 1962. The duo met in 1963 and have been singing together since. They were also very talented dancers. When $\mathrm{Al}$ showed us the Dog dance he did it on one leg and two arms. During the Alligator he crawled around on the stage floor. When the pair demonstrated the latest dancing crazes, The Camel Walk and The Horse, they imitated the animals too. Both were very capable of gliding across the stage on one foot with the other leg raised. It was known as The James Brown.

Jackie sang like Tina Turner, while Al mostly resembled Chuck Jackson. Jackie was quite small, while Al was of medium height and they were a very powerful and entertaining duo.

“There Was A Time” gave the couple many opportunities to show how to dance the James Brown. Jackie imitated Tina Turner in "I Found A Love” (Wilson Pickett). "Get Out Of My Life Woman” (Lee Dorsey) came with a rural humour as a short theatrical skit with big gestures.

During the concluding "Please Please Please" Jackie hung the mantle on $\mathrm{Al}$ who then went around and shook hands with the audience. Every aspiring male soul artist needed to know all about James Brown's stage routine before heading out on a low budget tour on the he "chitlin' circuit." 
The artists shared a dressing room behind the small stage where we sat and talked. Once the interviews were completed, I could hear the Essene Brotherhood started pumping out the classic soul riffs.

\section{Showtime!}

Tonight's performance was probably a public rehearsal before going out on a package tour in the southern states. Therefore, it was never announced. Luther was perhaps part owner of the club, or knew the owner well enough and could borrow it for their rehearsals.

It was a quality package. But the artists did not have any current bestsellers to lean on. Did the tour happen eventually? Or was it cancelled?

Luther seemed to be a kind, philosophical and religious person. He could afford to lose money sometimes with all his bestselling compositions.

\section{Sunday, July 14}

I had not received any info about churches with gospel concerts. So I sat at home and corrected and rewrote my notes. The door was open to the corridor to let in some fresh air. This hotel was the worst I stayed in during the tour. The heat and the bad smell was exhausting. I was very tired after all the long walks and waiting for buses in the sun. And the drinks the night before made things worse.

The temperature in the room stayed around 30-35 degrees 
Celsius or more. Beetles and cockroaches made their way over the floor and walls exuding a disgusting smell. Or was it the mattress and the sheets that were dirty from the start ...

In the evening I went to the Knight Beat club which stood at 276 NW 6th Street, at the intersection of 3rd Ave not far from the Continental. Knight Beat, I remember as a pretty big club with a decent stage and dance floor. I think it was a bit larger than the Continental. Or maybe it was more people at the Continental when Vivian Reed was there. Both clubs had large, youthful audiences. Foxes Den, where I had been the night before, had a red-coloured plush interior and an older, sophisticated audience. The scene was quite small but adequate for a jazz combo, a stand-up comedian or striptease. People sat at tables while the space for dance was not so abundant.

The backing orchestra, Frank Williams \& The Rocketeers were a six man strong combo. They were OK, but not in the same league as the Scott Brothers in Chicago. They offered the usual mix of soul classics and were perhaps most successful with James Brown's “There Was A Time.” (Which was a song that every band must play every night ...)

Frank Williams specialty was imitating other singers and he did: “A Change Is Gonna Come” (Sam Cooke), "If I Had A Hammer” (Trini Lopez), and then he imitated Joe Tex, and a hoarse and rough Louis “Satchmo” Armstrong.

Then came the Fabulettes:

They were Miami's best female group and had recently and 
finally been renamed to avoid confusion with other Marvels groups. "The Fabulettes is our current artist name, and the name we play under. Marvel is occupied by others” Maybe this was a step from the ashes to the frying pan as there were a Fabulettes group also in Los Angeles. They were born in Georgia and had later moved to Miami - three glamorous young women, well dressed and with interesting necklines.

Addie Williams was their spokeswoman and perhaps the intellectual of the group. She had been singing for ten years.

Annetta Shell had ten years of Gospel experience. And it was still her kind of music. She sang lead on most numbers.

Loretta Ludlow had moved to Miami at age twelve. She was perhaps more beautiful than the others and more of a diva. She knew James Brown and had persuaded him to produce a record with them a few years earlier.

The group's collective favourites were Aretha Franklin, The Supremes and James Brown.

It was impolite to ask women about their birth date, but I guess they were born around 1943-44.

They had recorded in 1961 as The Charmettes on Dade Records and Hearts Of Stone was released. Later James Brown produced “Tonight” / "One More Time” with the group. During 1959-63 they were still in school. In 1963 they were baptized the Mar Vells and recorded “Go On And Have Yourself A Ball” / “This Can’t Go On” for Angie Records in Philadelphia (Angie was also the name of the person who wrote the songs). 
In 1964 they recorded as The Fabulettes on the Monument label. The songs were "Mr. Policeman," "The Worrying Way," “Screamin' \& Shoutin',” “I'm In The Mood For Love” (written by Jimmy "Mc” Hughes), “The Bigger They Are,” and "Money” (Barrett Strong ). The group’s fourth member Mattie Lovette then left the group and sang no more with them.

This evening they did:

"Sincerely" (The Moonglows) where every member sang lead alternately, but where Annetta had the main responsibility, "Get Ready" (The Temptations), (Annetta lead), "Blue Moon,” "Higher and Higher” (Addie Williams - Lead), "I Heard It Through The Grape Wine" (Annetta-Lead), "Yours Until Tomorrow" (Addie-Lead), "Chain Of Fools”(Annetta-lead) and dancing by all “Think” (Annetta-Lead).

They were good singers and their stage show was appealing but maybe a bit too polished for my taste. In the US, the Fabulettes had many competitors. After the show, we sat at a table in the middle of the room. We also talked about Betty Wright, then just fourteen years old, who had one of the biggest local hits with Girls Can't Do What The Guys Can (She was launched as a child genius because she had a very high intelligence).

The radio was on in my boiling hot hotel room. These are some of the best songs I heard there:

"We’ve Had Some Good Times Baby" - artist unknown, “Competition Ain'tNothing”-Carl Carlton, “Slip Away”-Clarence Carter, “Dear John”- 
Jackie Moore, “Need To Belong”-Laura Lee, “United”Peaches and Herb, "Handy Man”- artist unknown, "Struck My Hub” - Willie Tubblin, “Layin’ It On You”-Bobby Patterson, "What A Man”-Linda Lyndell, "Love Is Like A Baseball Game”-Intruders, “To Love Somebody” - Sweet Inspirations, "House On The Corner"-Don Covay, "Seems You've Forsaken My Love” - Maxine Brown, "Baby You Move Me"-Ben Aiken(Loma Records), "Stop"-Lonette (or Betty Lavette?), "Send My Baby Back"-Freddie Hughes, "Girls Can't Do What The Guys Can”-Betty Wright, "She’s About A Mover"-Otis Clay, "You Got Everything(What) I Need”-Freddy Scott, "98 Cents Plus Tax"-Detroit City Limits, "Hitch It To The Horse"Fantastic Johnny C ("the funky walk is alright, the horse is out of sight”), "ICan’t Stop Dancing”-Archie Bell \& The Drells, "Don’tMess With Cupid”-Shirelles, “The Power And the Glory”-Benny Latimore, "Coo Coo Over You”the Hueys, "Got To Have You”-Fantastic Four, "What Can IDo Without You”-Linda Jones, "SoulLimbo"-Booker T \& The MGs, "Consol(id)ation is True”-Sensational Nightingales, "ICan’t Break Away From You”-Sam Baker, "Broadway Freeze”- Harvey Scales

Monday, July 15th

Next stop was New Orleans. The plane took off at 6:40 in the evening. It was a short distance between these southern state metropolises. I felt quite happy with my time in Miami. My expectations had not been so high. But it had been five intense days. Lots of things happened here. Their recording industry had more in common with other east coast cities (New York, 
Baltimore, Philadelphia) than with southern cities like Atlanta and Memphis. Music experiences had not been as intense as in the Chicago clubs. Those who worked in the recording studios were perhaps not as talented as in Memphis, and Memphis/ Atlanta had more of the southern hospitality

\section{Postscript}

Eleven years later, I received a letter from Hank Ballard. One of his King LPs was called Mr R\&B, and I took that name for my business.

He was the leader of one of the biggest groups of the 1950s - The Midnighters and had hits also in 1960-61 with songs like "The Twist" (he did the original), "Finger Poppin' Time” and "Let’s Go, Let’s Go, Let’s Go.”

Hank is perhaps best known for his "risky" and ambiguous texts but I thought that "Finger Poppin' Time” was a pure dance tune when it was released in 1960. But In the film In Bed With Madonna she explained that it also means female masturbation.

I take the liberty to publish this letter as it is related to my own contacts in Miami and to what happened next. Hank had written in response to the possible LP release of his lesser-known songs, which had not been previously available on LP. Unfortunately it never happened as Charly Records (UK) started releasing King recordings.

Dear Jonas, 9-19-79

It was such a joy hearing from you and to know that you have an 
interest in me and my group. I have a current record out on the London label. Title Freak Your Boom Boom which is doing very well for me.

A couple of weeks ago I issued a license to London of Canada and U.K. My contract with London is solely USA.

Maybe you and I and my associate can make us all some money. I have a joint venture production with a friend you should know, His name is Luther Dixon. He was co-owner of the Scepter Record Co. who had prod. on the Shirelles, Chuck Jackson, and Dionne Warwick. At present we are recording an album on Chuck Jackson here in Miami and it just might be the greatest album he's ever had. We are also planning an album on the Blue Notes the group who was formally with Harold Melvin + the Blue Notes.

I'm also getting my next single together which I think will be the biggest thing I've had in a long time. It come with an album until I have a big single, it takes a single in the USA to carry an album.

Jonas, I'm very interested in a tour over there if you can arrange it. I've never been on tour on foreign soil, even though my records sell quite well over there. I've had offers but the money was never right. So I decided I'll wait until the time is right.

Jonas, write and let me know in detail what you want in terms of recording, tours, and etc. If you think we can make some money together don't hesitate to let me know. We have quite a list of 
original material, a staff of ten writers and a four track studio for demos.

I went to Nashville Tenn. last year and I recorded six sides of my old material for the K-Tel inc. And in April of this year I did four shows at the Howard theater in Washington. DC and had SRO (Standing Room Only) every show, and was really surprised because it was my first time out in four years. It's amazing how they still like that old stuff.

Incidentally my daughter is ticket agent for Delta Airline in Phila. Pa. and for the past five years she's been coming to Stockholm, Sweden on her vacation, she loves it over there. Had I known you a couple months early I would have given her your address.

So next year when she vacation there she'll come by to meet you. Jonas send me your telephone number. My number is area code (305) 751-3383 Miami Fla.

Do let me hear from you as soon as possible.

Sincerely

Hank Ballard 


\section{New Orleans}

July $15-23,1968$

Monday, July 15, 1968

The plane to New Orleans left Miami at 6:40 pm. After arrival, I checked in at The Georgian Hotel on Canal Street. It was located in a run-down house with shabby grey-green carpeting.

New Orleans was a of course a natural destination for me, but I did not know a soul in town or where I should go. I had only heard Fats Domino in his "The Fat Man" singing about the streets of Canal and Rampart, and Bourbon Street was mentioned by others. Within a few minutes, equipped with a newly purchased map, I was on the way to Bourbon Street. It took less than a ten minutes quick walk to get there.

It was a Monday night, but the heat was on there. The French Quarter reminded me of the Soho district of London. They had the same healthy cross-fertilization between music clubs and striptease joints. In such environments good music usually 
thrives. The noise was almost deafening with all music, drinking people and cars using their horns trying to make their way through the crowd.

Outside a strip club, I saw Lili St. Cyr's name. She was a headliner in the short film cinemas of Stockholm specializing in documentaries from nudists camps. Unfortunately, the projector machinists used to cut away frames for their own collections and in the end there was not many seconds left for the audience to enjoy. She had been the undisputed queen of striptease in the 1940s and 1950s. Only six weeks earlier she had celebrated her 50th birthday.

Here and there were small "holes in the wall" where you could buy a beer and maybe a drink if you were too tired to walk the few steps to the next bar. But all distractions faded away when I saw Fats Domino's jovial face looking at me from a large poster outside Al Hirt's (501 Bourbon). Outside the 577 Club opposite, were the faded colour images from Clarence 'Frogman' Henry 's tour with the Beatles. Through the open doors his distinctive vocal was heard.

This must be the most music-filled street in USA. Frankie Ford resided at the Backstage while Roosevelt Sykes and Smilin’ Joe (= Cousin Joe) worked back to back at Ye Old Tavern of the Court of Two Sisters. Art Neville \& The Neville Sounds could be seen at the Ivanhoe piano bar (601 Bourbon) and Benny Spellman in the Dream Room. All this in just a few hundred meters, and then I had not counted the traditional jazz and other musical attractions. On some nights you could see young black 
boys tap dance or even do the hambone in the street for pennies. They usually took a break after a couple of minutes.

Bourbon Street's biggest clubs were called Al Hirt's and Pete Fountain's. These Dixieland musicians probably also owned these clubs. The Court of Two Sisters had the cheapest drinks on Bourbon Street so I first went in there. This was a piano bar and the bowl on the piano was a tradition that certainly existed in New Orleans since long before Jelly Roll Morton days. Here guests could deposit their bills if they wanted to hear a particular song.

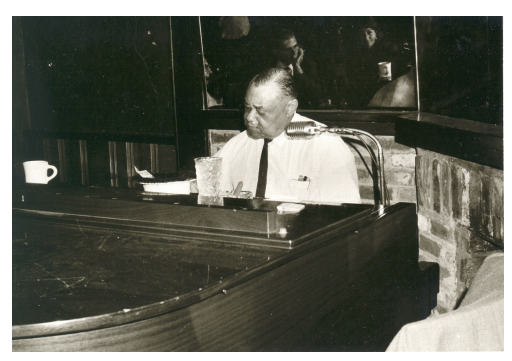

Roosevelt Sykes at Court of Two Sisters, Bourbon Street

Roosevelt Sykes, or Rosie, as he was known, had just started his set. He played the piano and sang and smoked cigars and talked with friends. His face always lit up when he saw a familiar face come through the door. A couple from St. Louis was there. Rosie asked what was happening in his old hometown, but the couple was perhaps a little too drunk to be able to give a good review.

In the first set Rosie did:

“Stuffin 'and Truckin'," "Woman In Atlanta," "Night Time Is The Right Time” (His version was a little different from Nappy Brown's and Ray Charles' recordings), "Honeysuckle Rose," "Stormy Weather," "Driving Wheel," and yet 
again: "Night Time Is The Right Time," and "What'd I Say," “Goin' Slow Down.” He concluded with a stomping boogie woogie.

It was a fine set and afterwards I complimented him and reminded him of the great success he had in Stockholm at the 1966 American Folk Blues Festival. The audience did not want him to leave the stage, and he "had to" do two encores.

Then Smilin’ Joe, perhaps better known as Cousin’ Joe (born Joseph Pleasant, 1907-89) took over the place behind the piano. He was very well dressed, even a little snobbish. He wore the latest James Brown styled clothes: a jacket and polo shirt plus a medallion around his neck. He was sharp. His repertoire consisted of blues, soul, standards and popular songs like:

“Trouble In Mind,” “Walk Right In,” "How Come My Bulldog Don’t Bark” (with a line about a razor), "Nothing Takes The Place Of You” (Toussaint McCall’s soul hit), “Good News” (Sam Cooke), “Lazy River," "You're Nobody 'Til Somebody Loves You," “Undecided,” "Stardust," "Let The Good Times Roll,” “Just Like a Woman,” “(Sometimes I Wonder) Why My Baby Don’t Write (To) Me,” "CottonFields,” "Way Down Yonder In New Orleans.”

Joe was in a good mood, sucking up the applause.

These artists had an extensive repertoire. It was needed for their hour-long sets between eight at night and four in the morning six or seven nights a week. I made it a habit to always say hello and sit down for a set or two whenever I walked down Bourbon 
Street. Rosie was so nice and had so much to tell, that he always kind of seized me when I arrived.

I never took time to talk to Smilin 'Joe even though I noticed that he circled around and probably was interested in an interview. I had no idea that he had done so many great $\mathrm{R} \& \mathrm{~B}$ recordings either.

After a while I hurried on to Frankie Ford (born 1939/1940 died 2015), who appeared at the Backstage. But it was very disappointing. He played tired standards and show tunes facing a white, middle-aged, female audience.

It is ironic that Frankie, who later came out as gay, didn't play his rock and roll tunes that would have attracted a young male audience. His amazing "Sea Cruise," a hit in 1959, is one of the best rock and roll songs by a white artist ever made. Even the B-side Roberta on Ace Records is great. The expressive line from "Sea Cruise" "I'd like to boogie woogie like a knife in the back" is mind blowing. But Frankie had Las Vegas ambitions and wanted to be the Liberace of New Orleans at these hours: 23-24, 01-02, 3.00-3.30 and 04-05.

Now he sang: "Until The 12th Of Never," "Here We Go Again,” “Then You Can Tell Me Goodbye.”

Then I had to leave as the staff persistently tried to make me buy more expensive drinks at $\$ 1.50$ each. I crossed the street to see Clarence Henry.

When I came back ten years later, Frankie had beaten the attendance record at the Backstage after an unbroken stretch at 
the Backstage. But Clarence had been even longer on Bourbon Street, and there was always more people to see him.

This evening he did, among others:

"ButIDo," "Swing Low SweetChariot”'(wherehe satdown atthepiano and interrupted the song with a spoken part of black power philosophy), "Please Please Please” (James Brown), "Hi Heel Sneakers” (Tommy Tucker), "Glory Of Love,” and a swinging and fine version of Jesse Hill's “Ooh Poo Pah Doo.”

It's not accurate to call Clarence a R\&B singer. Mostly, he sang pop songs, but with a swinging New Orleans beat, which made him very pleasant and fun to listen to.

His orchestra was first rate. The musicians that did not play with Fats Domino, but were qualified for it, could often be heard with the Frogman instead.

Among others were Bob French (born 1937) who played drums and Warren “Jake” Myles (Big Boy Myles brother), who played the piano. Before I left to go home and sleep, I shook hands with Clarence, and we decided to meet again later that week.

Being in New Orleans was comfortable and convenient. In the French Quarter and Bourbon Street there were both blues, R\&B and soul clubs and at the far end on St. Peter Street was Preservation Hall for the jazz purists. These visitors seemed to be only interested in music and often sat close together on the floor to be as near to their idols as possible. The other clubs were more comfortable. 
The majority of the Bourbon Street crowd was white. The soul clubs that were outside this area mostly had weekend performances for an all black audience. But further out, at the outskirts of New Orleans, the clubs seemed to be more integrated.

Tuesday, July 16, 1968

First I went to WYLD radio station at 2906 Tulane Ave. It was the leading soul and R\&B station in New Orleans. All the DJs were busy but I got a brief chat with Gus “The Groove” Lewis, the station's program director. He had also made recordings under that name.

I asked him about the clubs and where I could get hold of the $\mathrm{R} \& \mathrm{~B}$ and soul stars. I was especially anxious to meet Professor Longhair and Huey Smith. I had found the Watch single "Willie the Prince" / "Third House" on the Corner with Professor Longhair in early 1965 in Stockholm in a used record shop. Later Guy Stevens’ Sue Records released "Looka No Hair” / "Baby Let Me Hold Your Hand” from the Ebb catalogue recorded in 1957.

“Longhair does not get any gigs anymore,” said Gus, “and he lives outside town.” He had not heard anything about Huey for a long time either. But Gus thought it was Huey who was behind the group the Hueys and the song Coo Coo Over You which had been a decent hit in New Orleans recently.

Did Huey and Longhair get any occasional studio work? Gus did not know. Irma Thomas worked in the southern states but 
had New Orleans as a base, said Gus, and Aaron Neville, Robert Parker, Curley Moore and Diamond Joe were in town as well as Ernie K-Doe. But none of these had anything big happening.

Ernie K-Doe was at "Burnells in Sere St.” He also recommended that I visit Club 77 on North Claiborne, Nite Cap on Louisiana Ave and Mason's VIP Lounge on South Claiborne.

Gus said that Sansu Records, Allen Toussaint's and Marshall Sehorn's record company, was located at 1211 St. Philip Street (Ph: 524-3262). I continued to walk there.

It was a small, white one-story wooden building in a fairly affluent black part of town. It looked more like a decent singlefamily housing than an office of the most successful record company in New Orleans at that time.

It was a bit larger than the classic "shotgun houses" in New Orleans. They were long, narrow buildings where a shooter at the main entrance can kill the whole family with a single hailstorm.

Marshall was away, but Allen would come by at any time, said the secretary. But he kept irregular hours so she really she did not know when ... I often found myself sitting at Sansu waiting. It was hot outside but here a little cooler because of the air conditioner.

Everything took a long time in New Orleans. People did not show up for appointments or came too late.

At Sansu I got a long list of clubs worth visiting: 
Nite Cap (Club \& Lounge), 1700 Louisiana Ave,Mason Lounge, 2309 S. Claiborne, Red Carriage, on La Salle Street, Whitney Devil's Den, 2121 Bank Street (at the corner of Tulane and Bank Street), Club 77, 810 (or 700) North Claiborne, Ivanhoe Piano Bar, 601 Bourbon, 577 Club, (where “Frogman” Henry appeared), Al Hirt’s, 501 Bourbon, (Gloria’s) Living Room (St. Bernard - one block from Broad Street), Sylvia's, on Spain \& St. Roman, Jazz Corner, on Frenchman. And later were added: Five Hundred Club, 441 Bourbon, Perkins Bar, at Taylor Street and Kenner? (Where perhaps Tommy Ridgley and Chris Kenner could be), Shadowland 1921 Washington at the corner of Dryades, The Dew Drop, Washington and La Salle (2836 La Salle),The Sands Lounge, 800 (or 801) Jefferson Highway.

Another club was at 701 Loyola Ave. The Club Soul City was in the suburbs. On the 28 of July something was about to happen at 1740 Baronne St ...

Allen did not show up that day, but I headed down to Bourbon Street again in the evening. First stop was the Court of Two Sisters. There I had a long and hearty chat with the extremely nice and sympathetic Roosevelt Sykes (1906-1983).

He was born in Helena, Phillips County, in 1906. His father's name was Ed Sykes and he was a musician and his mother, Allie, was a housewife. Ed played guitar and mandolin in a style that Rosie described as "a kind of swing blues.” His most popular song was "I Came All The Way From East St. Louis With Just One Lousy Dime.” He appeared on Saturday night parties, or picnics, where both black and white, from the cotton fields, sawmills or timber logging gathered. When people were eating and drinking they entertained with guitar, mandolin and violin. 
But when race relations degenerated, the integrated parties ended.

When Rosie was six years old his father died and when he was seven his mother died; he grew up with his (maternal) grandfather Adam Bragg. He was a preacher of a Baptist church in St. Louis. He did not remember much of his parents. In the church, he heard spirituals and gospel music. Rosie preferred the older style ("more harmony") before the gospel heard today. During his early days ragtime had become blues, said Rosie.

His mentor and the one who taught him the basics of the blues was Leothus (Lee) "Pork Chops" Green. He was a better piano player - with cleaner appropriations - than myself, said Rosie, and also a decent singer.

Rosie toured and worked with Lee "Pork Chops” Green for 15-20 years. He also learned much from Jessie Bell, who had his own style, and from Arnold "Wild Eye."

In June 1929 came his recording debut - “44 Blues” on Okeh 8702 (Rosie still remembered the issue number.) He got his record deal when he demonstrated pianos in a music store on Market Street in St. Louis. The talent scout Jesse Johnson came by and liked what he heard and took Rosie to New York and Okeh Records, which then was located in Union Square in New York. Then came the blockbusters “All My Money Gone,” "Henry Ford Blues” (1934), "Skin And Bones” (1936). He came to Decca in 1946. In 1956, he had some success with "The Night Time Is The Right Time” (RCA Victor), which he had recorded earlier. 
Rosie became a professional musician in 1930. But already when he was 16-17 years of age, he used to leave his hometown and hitch free rides with freight trains. No one commented when he left or when he came back. Rosie described himself as rather neglected but he was a handy child and made no major demands and Rosie said that he had not been hurt by his upbringing. But he also said that "no happy man can sing the blues. You have to descend into the abyss - bring yourself low down."

On the freight trains were all kinds of vagabonds. Rosie dressed in his worst rags and kept only a few coins in his pockets. But under his shirt cuffs he kept his money - often several hundred dollars.

He had a worn suitcase. When he arrived in a new city, he changed clothes, and went to the nearest bar or gambling saloon where there was a piano. Someone would always ask if he could play ... and Yes, Yes! The tips flowed into the bowl on the piano and the bar owner sold more drinks and was satisfied, and he also used to ask if Rosie could come back the next day. Rosie promised, but usually he left town and travelled on.

He started his own group - Roosevelt Sykes \& The Original Honey Drippers - that he led between 1935-58. Then he began to read music. Around 1930 Edith Johnson mentioned the Honeydripper for the first time in a song. Then Rosie took up the theme in his own song: "The Honeydripper is a sweet man for a girl.”

He had been married three times: in 1933 with Isabella, and around 1937/38 he married for the second time with Vivian for 
five years and then he was a bachelor until the third of December in 1956, when he married Mercy Dee, his present wife. He had a 35-year old daughter with his first wife. And two boys, six and thirteen years old and a nine-year old daughter with his third wife. During the war he worked in a munitions factory in Chicago.

Rosie used to perform at theaters like the Apollo or Lafayette in New York during the vaudeville era when they had burlesque, movies and a blues pianist. In St. Louis, he stayed in places like Red Bird and “Colum's” Nest on Marque Street. It was tough in Mississippi. He didn't like it much there. During tours he often played in school houses. But he preferred to play in concert halls and at school concerts.

Particularly successful was the show in Cambridge, England in 1961. Then he also appeared in London, Birmingham, Brighton and Nottingham. He was at Carnegie Hall in 1963. In Chicago, he had in recent years appeared at a Technical College on Wabash Ave, and in the suburbs.

He described himself as a honky tonk blues player, and it is in these places for gambling, prostitution and illegal liquor and beer trade he has been the most. Knife fights, gun battles or regular gang fights erupted there sometimes, and then he had to dodge the flying bullets. At that time a blues singer had a pretty good reputation among other blacks, but now it had gone downhill. White people started to appreciate the blues after 1945.

Rosie was always happy to share some words of wisdom: 
"Blues is the truth and tells it like it is." "Blues is a spice. Salt makes you appreciate the sweet taste better. Even in a sponge cake you must have a little salt." "The Blues is the salt that makes other music such as jazz, R\&B, etc. sounds better.” "Blues is the foundation for other music such as jazz and R\&B." "Jazz is $50 \%$ blues."

“In the beginning the Blues was called 'reels' (“reals?”)," said Rosie. It was only in the 20th century it got its present name and it was taken from "being blue."

This evening I heard Rosie do:

"Women In Atlanta,” “St. Louis Blues," "Kansas City” (I think Rosie used Little Willie Littlefield's piano-based arrangements. But he had heard guitarist Jim Jackson do this song already in 1922-23; with another arrangement.)

Next stop that night was $\mathrm{Al}$ Hirt's where Fats Domino was. Rosie said that Fats Domino learned a lot from him long ago and asked me to say hello to him. The club was owned by jazz trumpeter Al Hirt and was the largest on

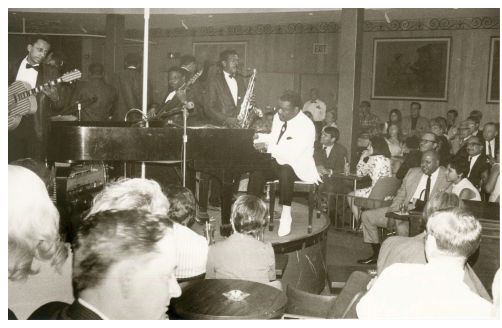

Fats Domino at $\mathrm{Al}$ Hirt's (Tenor saxophonist next to Fats is Nat Perrilliat)

Bourbon Street. It had a circular stage that slowly spun around while the performers played, and you could see the musicians from all possible angles. I remember the premises as rather narrow and elongated, perhaps because I was in the part closest to the entrance. 
The band included Roy Montrell (guitar), Herb Hardesty (tenor sax), Nat Perrilliat (tenor sax, 1936-1971), James Davis (bass) and probably Clarence Ford (1929-1994) (baritone sax), whom I later shook hands with in the audience at Frogman Henry's place.

They started with a jazz song and then Bobby Hebbs "Sunny," which had been a big hit two years earlier. Then a new jazz song and Bobbie Gentry's “Ode To Billy Joe.” The first part of the show with easy listening big band jazz was not that exciting and I walked around the room. Then Fats made his entrance in an elegant white blazer and he kicked off directly with:

"Blueberry Hill” and followed with a medley of hits, containing, among others “I'm Walking and Blue Monday.” Then followed: “Just Like A Woman,”An instrumental,“I Want to Walk You Home,”“Trouble Blues,”Instrumental,These two instrumentals were either "Fat Man's Hop," “Second Line Jump” or “Domino Stomp” or perhaps another one of the very fine instrumentals Fats recorded during the 1950s, "Trouble in Mind" (he did it 2 times) "I'm Ready," ... then Fats did a blues with the phrase "another mule is kicking in your stall,"“C.C. Rider,"“Natural BornLover,"“When The Saints Go Marching In.”

The band sounded good, of course, even if they had played most of these numbers a thousand times.

I especially appreciated guitarist Roy Montrell. It is nice when a guitarist is playing in the lower register. Almost like a bass. But I don’t like to hear a bass player play like a guitarist.

The venue was not full - it was the beginning of the week and 
early in the evening (maybe 200 people were there). Most were white (approximately two thirds) and in lower or middle age. Most of the tables were occupied, and I stood against the wall.

Fats had a huge highball glass on the piano. Just like Amos Milburn when he sang songs about the Bad Whiskey. When it was empty, the waitress came in with another full glass. Fats emptied it resolutely.

Fats sang "Trouble In Mind" twice because he noted that "both he and the audience felt so good about the blues.” It was a fine blues-based performance that evening.

Afterwards, I exchanged a few words with the club's manager. It was often a good way to get free access to the artists' dressing room and a free drink. And to come back later and not have to pay admission. But he seemed frankly a bit scared of both Fats and his manager ...

After a while Fats appeared from the inner regions. When I started talking to him, it was evident that he was very drunk. In fact I wondered how he was able to perform. I tried to ask questions but received only incoherent replies. Fats resolutely took care of my notebook and wrote his autograph there: "Luck Fats Domino.” 


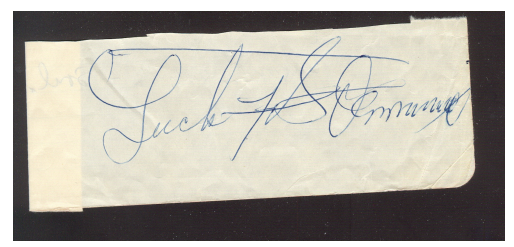

Fats Domino autograph

His manager, Bernard Dunn, came after a while - also a little drunk and in fact a wee bit aggressive. I think he mistook me for a promoter from Europe who was trying

to lure Fats off to Europe ...

He told me that Fats had a record deal with WB and the next Fats Domino single would be released in two weeks on Reprise, Frank Sinatra’s record label.

Fats had not had a hit in four years and his time as an indemand and highly paid rock and roll performer was over. Long performing stretches in the home town never brings any serious money, but saves hotel expenses. It might not even be enough to keep a permanent big band and support a huge family?

His latest record, a cover of the Beatles' "Lady Madonna” on Reprise was heard on the radio. But it took eight weeks for it to creep to the 100th place in the charts where it stayed for two weeks.

The meeting with Fats was quite unsuccessful.

But it never affected my admiration for this incredibly talented artist who created perhaps more classic hits than any other black artist (apart from James Brown) during the 1960s. And who managed to convey joy and joviality in the best spirit of Fats Waller and Louis Jordan. When I met him again on May 21, 1973 at Grona Lund in Stockholm, he was in an excellent mood 
and pleasant and positive. In his sax section then was Walter Kimble and Roger Lewis (baritone sax) and Maurice Simon.

(Ten years later, Maurice Simon was booked to accompany Nappy Brown on a Scandinavian tour. But Simon managed to be deported from Sweden after some criminal activity.)

When we looked at the pictures I had taken five years earlier, Fats pointed out that a couple of men had died in the meantime. It was tenor saxophonist Nathaniel "Nat” Perrilliat (1936-71), who fell unconscious during a gig with Fats in Sacramento, California, and died a few days later. Bassist James Davis died in a car accident (1970) where Clarence Ford and Buddy Hagans were seriously injured.

I also asked about Jewel King, who debuted at the same time on Imperial as Fats. Fats confirmed that it was a woman (I had not heard her then). Fats even sang a line from her song "Three times seven is twenty one."

When I came out on Bourbon Street again, I was offered \$5 for advanced sexual services by a motorized white man of 25 who was driving a convertible sports car. It was neither the first nor the last time it happened in the US. I guess I started to look skinny and worn out - like one who had escaped from a juvenile prison - and an easy prey to tempting offers.

I hurried to Back Stage to interview Frankie Ford between performances but he had a meeting so it came to nothing. He only said that Marshall Sehorn had planned to record him, before he rushed away. I went to the Dream Room where Benny 
Spellman appeared. But I never entered because Benny was not there at the time. (I think the club was located upstairs.) I never had a chance to come back. Someone had said that maybe Ernie K-Doe was there too, but that was not the case. I went home.

Wednesday, July 17, 1968

I felt tired after yesterday and took a refreshing walk to the center. New Orleans had the most liberal alcohol laws in the southern states where otherwise clubs had no right to serve liquor or had to stop serving at midnight. The entrance was often free in New Orleans, but that was compensated by sales of drinks. When going from place to place it could be too much.

After a while rain began to pour down and I sought refuge at a department store at Canal Street. In Elvis’ movie King Creole there was a similar looking department store where Elvis sings "Lover Doll” for his girlfriend.

In the evening I went back to Clarence "Frogman” Henry. He was born March 12, 1937 in Gretna, on the west bank of the Mississippi River near New Orleans, and he played the piano in church and sang too. But in 1955, he stopped singing gospel and started

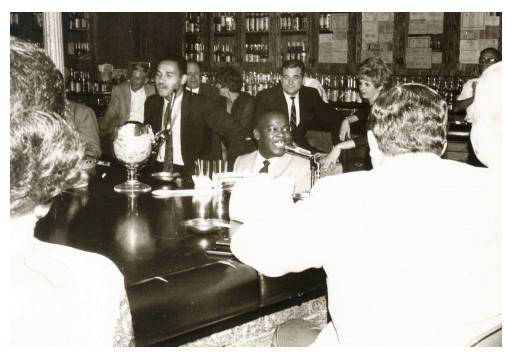

Clarence "Frogman" Henry taking over at the piano (from Warren "Jake” Myles) at the 577 Club with R\&B. He described his influences as gospel and Dixieland music, and later rock and roll. It was Fats Domino, Professor Longhair, Smiley Lewis and 
gospel music that influenced him the most. Today he played and sang the music he grew up with.

He was on the Chess/Argo label between 1956 and 1965. In 1957 he got his first hit with “Ain’t Got No Home” for Chess. Altogether, he released eleven records on Chess like “Ain’t Got No Home,” “Lonely Tramp,” “But I Do,” "You Always Hurt The One You Love,” “Lonely Street," “Standing In The Need Of Love,” “On Bended Knees.” (His Chess recordings were released mostly on Argo - the company's pop-label.)

In 1965, he came to Parrot Records and made, among others "Little Green Frog." The year after it was Dial Records where he recorded "Tore Up." His latest record was the "Shake Your Money Maker” for Dial, a song that also Elmore James and Bobby Marchan had recorded.

As a recording artist, he combined the sound of Memphis and Nashville, but he was not a soul singer, said Clarence. His stage show was pop in a nightclub-style. Dixieland with backbeat was his New Orleans sound.

He had worked with such diverse producers as Allen Toussaint, Buddy Killen and Berry Gordy and been six times in Europe. The images from the 1964 tour with the Beatles papered the pillars outdoors. He recommended a visit to the Delta Distributors at 1023 Baronne or Bologne/Howard but I never got there. I guess they distributed his records.

Clarence had performed locally for several years and knew all the local artists. I wanted to use him as a talent scout. But like 
many artists, he wanted to talk about his own career and not about others.

I think though, that it was Frogman who described Professor Longhair as a wino today.

The best place to look for Huey Smith was at the Dew Drop on 2836 La Salle, he said. "But Huey does not perform there. He is there to drink." I took the tram and stepped into a simple, medium-sized club with generous space between the tables. A small stage was in one corner.

I asked men of Huey's age, who stood at the long bar, if they knew where I could get hold of him. They shook their heads, but confirmed that he would be there and drink in the evenings.

Here all my R\&B favourites had been drinking: Wynonie Harris, Little Richard, Amos Milburn, Roy Brown, Ray Charles, Joe Tex and half of the soul elite. Both when they were touring and on top, but equally often when they were stranded in New Orleans and had extra time between gigs.

I said that I was interested in soul and R\&B and they recommended the Shadowland at Washington/Dryades or the Nite Cap lying nearby. The Dew Drop only had shows on the weekends.

At the Shadowland, it was completely silent. The place was in semi-darkness and at the bar sat a young man lost in a drink and he advised me to be there tomorrow instead. Then Irma Thomas would be there, as well as Diamond Joe and Curley Moore and many more. On a small piece of paper he wrote: Shadowland 
at $10 \mathrm{pm}$. Vocalists: Leroy Bates, Curley Moore, Diamond Joe, Phillis, Mowite, Joseph; Band - The Toronados.

Thursday, July 18, 1968

It sounded almost too good to be true! I just could not believe him. Wasn't he in fact the manager of a small group and wanted to lure me to see them there? On the same note, I myself had written "Lee Dorsey - tomorrow" - even he was somewhere nearby - but where? This club was really small. Could Irma, an international soul star appear in such small places, no bigger than a small café with a 10-15 tables. I asked the female bartender if she had something to recommend. She suggested I go to the Nite Cap, a bigger club, which was a few blocks away (at 1700 Louisiana Ave). Willie Tee \& The Souls could be there.

“Willie’s Walking Up A One Way Street” and “Teasin' You” were good enough for me to rush there immediately. But even the Nite Cap was empty and almost deserted. The club was maybe ten blocks from The Dew Drop. But after a while a pretty decent soul group showed up. (Here my diary is incomplete.) But it must have been Lil Wilbert \& The Fabulous Playboys and their repertoire consisted of soul standards in a rather short set. And someone also wrote down a phone number: 949-9447. Wilbert said their biggest hit had been "Funky Broadway, Part 1-2" on Paramount and that their latest record was "Lover and a Friend” on Seven B with Eddie Bo as a producer and arranger. He probably meant that Eddie Bo sometimes used the group on their own and others' recordings when Eddie was working as a producer. 
It had been late and I had visited many places and each new club meant at least a drink as soon as you sat down. It was difficult to collect the thoughts. Musically, the day had not been that interesting. I left the Nite Cap at 1:15 and went home to sleep and wake up refreshed.

I went back to WYLD to make a more formal interview with Gus Lewis (born 1932), their program director. The station started in 1950 and in 1958 it got its present name.

The station was entirely black-run and they wholeheartedly supported the Civil Rights Movement - and they intended to take an even tighter grip on the New Orleans African-American population (40\% of the total) with news, discussions and history, even if they lost some white listeners in the process. They played soul/R\&B for 20 hours a day and gospel between 6-7 am in the morning and 7-10 pm and had 50 songs on the playlist and 5-10 songs were replaced every week. The DJs could also add a favourite song of their own.

Gus “The Groove” Lewis had a high stack of new records in front of him on the desk. He told me that they got 350 new singles every week. He was just about to pick out the new discs to be played on the radio next week. But he sighed when he saw records with Lightnin’ Hopkins ("Back Door Friend”) and Junior Wells (“Wig Wearing Woman” or “Mystery Train”).

Guy put those relentlessly in the discard pile. "I do not understand why some record companies insist on sending discs that can only be appreciated in backward, rural areas," said the Groove emphatically. 
Otherwise, he was pleasant, and had recorded a couple of semiprogressive talk-soul records as a singer, songwriter and producer, like many DJs did. Right now, he had a record released by Bell Records - “Together” / "Let The Groove Move You.” He said that the summer had been pretty cool so far, both regarding new discs and riots, and gave an example of the station's commitment against employers who discriminated against black workers.

For that reason they boycotted Dixie Beer's advertising. (Result was uncertain. This beer flowed at a couple of the clubs I visited.)

Otherwise race relations were better in New Orleans than in other cities in the South. Here you could see both white and black children play together. The Groove also completed my list of clubs in New Orleans to visit.

Then I continued to Sansu. A young man with hair in a faint red colour was waiting for Allen Toussaint at the reception. I had not seen his picture before, but when he presented himself as Aaron Neville I started an interview immediately. His languorous soul ballads had made a big impression on me. He was one of the artists from the transition period between $R \& B$ and Soul that I was looking for. 


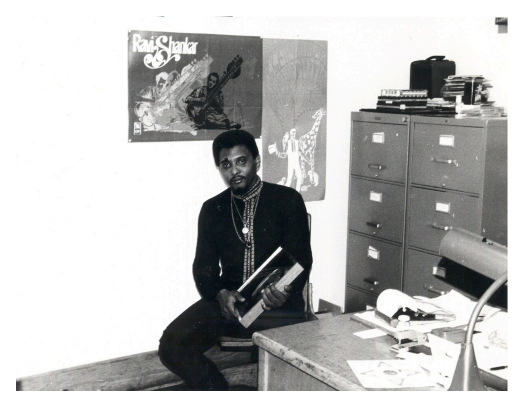

Aaron Neville at Sansu office

- Aaron Neville was born in New Orleans in 1941. He had a Catholic background and only sang hymns in church, but sometimes gospel and spirituals with friends. He actually formed a gospel group in the mid-1950s, but they were singing just for fun and never appeared in the church.

Gospel music thrived in the Baptist, the Pentecostal churches and the Church of God in Christ, etc., while hymns and European church music dominated the Anglican, Catholic and traditional Protestant churches formed by immigrants from Europe. Good gospel-based soul singers from New Orleans were not as common as in Memphis, Atlanta or Chicago, simply because the Catholic Church was strong among blacks here. Although the belief systems and services were mixed with elements from African voodoo religions from the Caribbean islands, like in Haiti.

Aaron played the piano, organ and drums, sometimes even on stage, and he mentioned his brother Art as one influence. He started singing with the doo-wop group the Avalons in 1955, and in 1957 with his brother Art in the group the Hawkettes. They performed in schools and local joints. Since then, the two brothers have performed together. When Art, then a black rock $\&$ roll artist, was drafted, Aaron took over the band.

In 1960 Aaron was contracted by Minit and recorded songs 
like “Over You,” “Everyday,” "How Many Times,” "Wrong Number," "Waiting At The Station," "Let's Live,” etc. Allen Toussaint worked at Minit as a composer and producer. He used his mother's maiden name Naomi Neville and perhaps confused researchers to believe he was a member of the Neville family. In 1960 Aaron toured with Larry Williams for seven months.

I first heard Aaron on a Minit collection LP called We Sing The Blues. Aaron was featured with "Let’s Live” (my own favorite) and "Over You.” Joe Banashak owned the Minit label but sold it in 1963 to Imperial Records, and Aaron left the company.

Aaron's highly skilled singing separated him from other, more untrained "personal" singers from the Crescent City like Lee Dorsey, Dr. John and Professor Longhair. This has given him admirers among fans of doo wop, ballad singing and even opera.

In 1962-63 he went back to Larry Williams, but otherwise he always sang with his brother Art. With both Larry and Art, Aaron handled the ballads and left the rock and roll and fast numbers to them.

A quiet period followed until he recorded “Tell It Like It Is” in 1965 on Par Lo, but it was not released until November 1966. It became a million seller and went to number two and stayed for fourteen weeks in the Billboard Hot 100.

Then began the problems.

“Those Three Words" was chosen as the follow up and Par Lo wanted a large part of the publishing and composer rights to the 
song. The song was written by Aaron's brother Cyril (born in 1948), and Aaron and Cyril refused.

Instead, Par Lo chose "She Took You For A Ride" as the sequel and on the Tell It Like It Is Par Lo album, “Those Three Words” is included as an instrumental. Aaron's vocal is taken away and the song is renamed "Bet You're Surprised.” Aaron (and Cyril) was not only surprised but very angry! The Par Lo LP is a failed album with short playing time and only nine vocal songs by Aaron plus two instrumentals with George Davis (guitar) and Red Tyler (saxophone).

In the middle of 1967 Par Lo realized they had made a mistake and released “Those Three Words," but it was too late, said Aaron and Minit had already jumped on the bandwagon and released an LP with older material under the title Like It Is. He did not want to do anything with Par Lo and did not record any more for them. He was waiting for his Par Lo contract to expire, and then Allen Toussaint had promised to record him for a larger company.

Aaron had been touring with Jackie Wilson, the Isley Brothers, the Five Satins, Spaniels, Coasters and appeared on local television shows, even in Canada. His own favourites were his brother Art, Sam Cooke, Larry Williams, Gene Allison and Pookie Hudson of the Spaniels. I think that Pookie, who also has a magnificent vibrato, was his biggest influence. (Incidentally, the Spaniels have also made a song titled "Those Three Words" ...)

I guess I was the first European journalist to interview Aaron. 
(The article was published in the Blues \& Soul in 1968.) Aaron seemed very sensitive and somewhat shy. Maybe he was on guard after all difficult experiences with record labels. He seemed to carry "a chip on his shoulder." He reminded me of James Dean, or other rebels without a cause, who hold much inside but sometimes explode. Aaron was aware of his amazing talent as a singer. He really wanted to succeed. But his career had hit bottom. No matter how he tried hard, he came nowhere. With every day that passed, so did his chances of a come back.

He was frustrated.

Aaron was the first and only black artist I met that summer who was tattoed. On his chest he had a tattoo with the name Teresa. But he was unhappy because the tattoo artist had spelled her name wrong. It should've been Theresa. On his left cheek, he had a sword and his arms were tattooed too. They didn't look professional. Were they made in jail? He later took up body building - another good way to ease the pressure - and maybe would give him a chance for an extra part in a prison film.

While we talked inside the office, three women had arrived to the Sansu rehearsal room. It was the Triple Souls, New Orleans leading female background singers. Mercedes Morris sat at the piano and played and sang "I Can’t Last Much Longer" (recorded by Betty Harris and the Triple Souls on Sansu), when I entered the room. On the piano stood a half-empty beer bottle.

I was naturally excited to meet these women. Not only because she played my favourite soul song from New Orleans. But 
because they were New Orleans' equivalent of the Sweet Inspirations (who worked with Aretha Franklin) - but better!

Their efforts on several New Orleans soul classics had certainly brought them attention from soul lovers around the world. They showed me an article from a local newspaper in which they were portrayed. The Triple Souls were beginning a career as a group. So far they had been fairly anonymous but now they planned to begin performing in clubs.

The three women were Mercedes Morris, Sena Fletcher, Inez Cheatham.

Mercedes Morris was the oldest and probably the most experienced singer. I remember her voice was located in the alto register.

Sena Fletcher was very nice and sweet and had just recorded a solo record for Sansu. She was born in 1947. Her father was a priest and she had sung in his church throughout her life. But it was not until six months ago, that she began singing professionally as a solo artist. Her first record on Sansu was "It's Not Unusual” / “All For The Love Of My Man” produced by Marshall Sehorn. Allen Toussaint plays the piano.

Inez Cheatham was born November 25, 1946 in New Orleans (actually the very same day as myself; at that time I didn't think much of it and never told her). She began to sing gospel and was the president of her church youth choir where she also sang solo. When seventeen years old, she crossed over to $R \& B$. She had composed songs since she was nine, and had 200 songs in 
her portfolio. Her first recording was a duet with Eddie Bo at Seven B (“Lover And A Friend”). Next record would be released already next week. (Inez later recorded for the Scram company under the name Mary Jane Hooper with Eddie Bo as a producer.) Inez had a lot of plans and was very optimistic about the future. Success awaited her for sure!

The Triple Souls had been formed two years ago. Today they were featured on almost all New Orleans recordings where a female group was needed. Besides working with Betty Harris they also mentioned singing on records with Robert Parker and Lee Dorsey. They emphasized "Touch Me" with Chick Carbo which became a local hit.

The girls were on their way to Cosimo's studio for a session. They asked if I wanted to be in their company. Of course I wanted, and Aaron who was tired of waiting, also came along. We squeezed ourselves into a car with Aaron at the wheel that took us down to 748 Camp Street. I guess it was Aaron's car.

This was a rather large three or four story building - narrow, but not standing by itself - that seemed to have been used as a warehouse for colonial products. Above the door it said $748 \mathrm{Jazz}$ City. When we walked up a rickety wooden staircase, like in a regular barn, we arrived to the floor where the studio was. 
It had a glass closed-in room with tape recorders and mixing boards and outside on a concrete (?) floor stood the microphones. It was a large room where you could fit a couple of symphony orchestras, with a high ceiling. Aaron kept mostly in the background. He walked

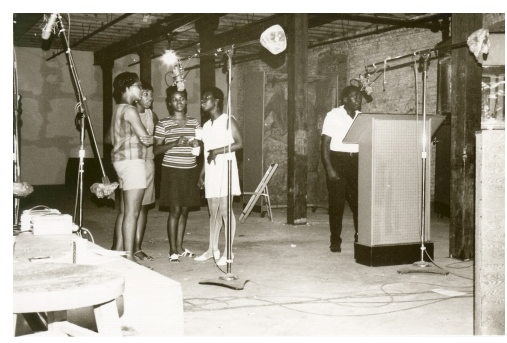

Recording session at Cosimo Recording Studio with Little Sonny (Jones) and The Triple Souls (left) plus extra girl. around or sat and fanned himself with an empty sleeve to his Par Lo LP called Tell It Like It Is. There were droves of this in one corner of the studio, and it probably reminded him of his legal and professional problems and that this LP had become a massive flop.

Little Sonny Jones (1931-1989) was about to complete the Bside "Soul Power" to a new disc on Scram Records. It was a funk-inspired instrumental where Sonny sometimes called out “Whip some soul power on me drummer!” It was not the kind of song that I was interested in buying. The organist had a "do rag” on the head that kept his hairstyle in place. On top he wore a hat. Aaron told me that it was Edwin Bocage aka Eddie Bo. He arranged and played organ on the session. Between takes I took the opportunity to throw in some questions to Eddie about his life and career. 


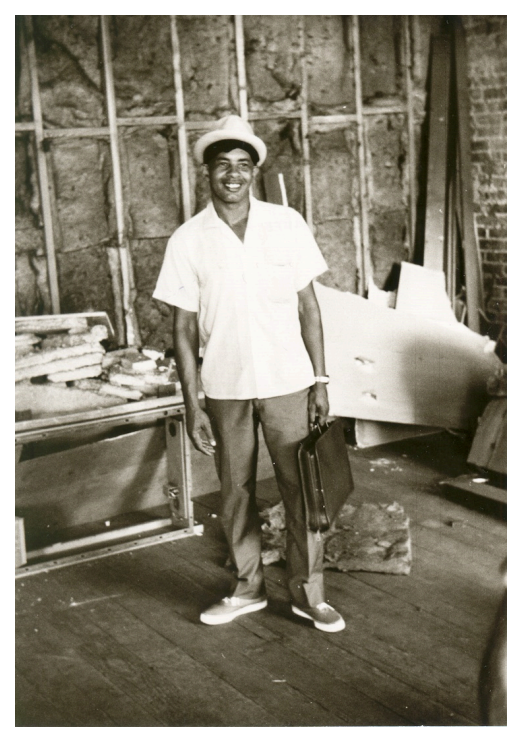

Eddie Bo in outer room of Cosimo Recording Studio
Eddie Bo was born in New Orleans in 1933. His mother played the piano in church and Eddie sang there accompanied by her during his youth. In 1950-52 he did his military service in the Army in Alaska. There, he also met James Brown. Both were boxers, but James was in a lower weight class so they never met in the ring. When he signed off, he got the opportunity to study at a music school in New Orleans from 1952-54 through the

G.I. Bill program. He also mentioned that he met Jerry Butler, not in the military but perhaps in a music school or later on a tour.

Eddie Bo’s recording career:

Apollo (56-57), Ace (58-59), Chess (59), Ric/Ron (1960-61), Nola (1965), Seven B. (66). He had played piano on early recordings with Robert "Barefootin"” Parker and was the voice that said “all night long” on Robert's All Night Long. Actually, this was an Eddie Bo record that was released in Robert Parker's name, Eddie said.

Among the songs on Apollo Eddie emphasized "Tell Me Why," "I Cry Oh" and especially "I'm Wise” that Eddie said became 
the model for Little Richard's “Slippin' and Slidin'.” A total of three records were released on Apollo. Ace released "I Like To Rock and Roll.” On Ric and Ron he had hits with "Check Mr. Pop Eye” and “Tell It Like It Is” (not Aaron Neville’s slow ballad, but a faster up tempo song). The owner of Ric and Ron died in 1965.

Then most of the recordings took place at Cosimo Recording Studio in the French Quarter, (It was often called "Cosmo” but the spelling was Cosimo.) It was there that Fats Domino, Huey Smith, Jessie Hill, Robert Parker and Irma Thomas and everyone else recorded. Now, the studio had moved to 748 Camp where all major New Orleans recordings took place.

Eddie arranged Irma Thomas’ first record “Don’t Mess With My Man” (Ron Records). Sometimes he played the piano on stage if it was in tune and sounded good. In 1959 he toured with Little Willie John in Texas. He wrote "My Dearest Darling” for Etta James and recorded it himself at Chess. "It was Etta's first hit on Argo,” he said (in fact, it was the second).

Now, while waiting for a new hit, Eddie sang locally. He worked as an arranger and producer for others - mostly for the Scram and Seven B. companies. His latest was a duet with Inez Cheatham of the Triple Souls ("Lover And A Friend"). (I prefer the B-side, a slow ballad where Eddie sings solo.) 
The owner of Scram, Al Scramuzza, was there (Scram, 1826 N. Broad Ave). He was a shellfish-fisherman and knew that the price of crayfish were 3-4 times higher in Sweden than New Orleans. He definitely wanted to export to me when

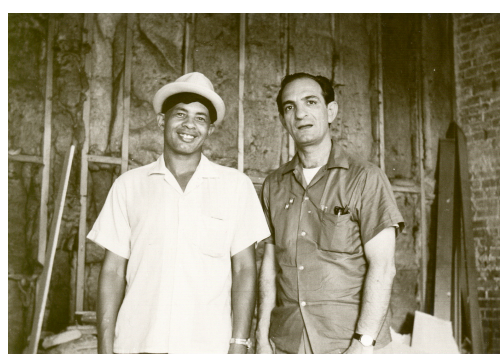

Eddie Bo and Al Scramuzza, owner of Scram Records, in corner of Cosimo's Recording Studio

I came back. (He later started other record companies like Power-Pac.)

The next song with Little Sonny was called "Stolen Moments." Sonny sang first to a pre-recorded musical background, and then the Triple Souls along with a fourth girl, with a more typical African appearance, added the background vocals. Between takes Eddie and Mercedes Morris shared a bottle of Rock and Rye - a premixed grog/alcopops that we also were invited to.

Aaron Neville, who understood that I was interested in older and even extinct and fallen stars, said that the bassist, who played on "Soul Power" was Alvin Robinson Unfortunately, he had gone home...

The studio was not air conditioned. It had a high ceiling, but the air was standing still under the rafters. I also used an empty album cover to fan myself with in the high summer heat. Before we parted, we decided to meet at Ivanhoe piano bar where his brother appeared. Aaron promised to sing a few songs. Great!

I never got a chance to interview Little Sonny, but he told me 
that he was opening with Fats Domino at Al Hirt's. I had missed his segment the other day.

After a couple of hours the session was completed and Eddie, Sonny and Al Scramuzza packed up their things and left. Eddie had a briefcase where he kept his arrangements. (He had a massive hit a year later with Hook and Sling on Scram.)

I stayed because Wardell Quezergue had entered the studio. Wardell (born circa 1933) was a respected and fairly successful producer who had worked with Professor Longhair, Willie T, Robert Parker and later Johnny Adams.

If I rate the New Orleans soul producers, Allen Toussaint is number one, then comes Wardell and after him Eddie Bo.

Tonight he had brought Charles Billum, about twenty years old, with him. They started working on "Mr. Teardrop," to be released at Nola Records. (Wardell and Nola had their office at 1913 Bernard Street.)

Unfortunately, there was no time for interviews, but I did have my share of the grilled chicken they brought with them and we stayed in the control room that was comfortably air-conditioned unlike the other studio spaces. Present were also Charles's father and two of his brothers.

“Mr. Teardrop” was a fine, typical medium-tempo soul ballad which I gladly would have bought if I had found it. But it disappeared without a trace, and I've never seen a song with that title mentioned anywhere. 
(The title and the lyrics give associations to Otis Redding's "Mr. Pitiful” and Bobby Harris splendid “Mr. Success.”) I did not speak with the studio engineer, a white man circa 35-40 years old. But I guess it must have been the legendary Cosimo Matassa (1926-2014).

I could not stay for the entire session because I wanted to see the Neville brothers at the Ivanhoe piano bar. On the way there I ran into Roosevelt Sykes, who was about to eat dinner. But I hurried on to hear Aaron whom I always I felt is one of the best soul singers ever. But he never showed up.

Art Neville \& The Neville Sounds stage show included:

"The In Crowd," "Tighten Up," "Hang On Sloopy," (Art vocal) “Watermelon Man,” “Cowboys To Girls,” (Vocal); Art’s vocal microphone was damaged and sounded awful. But thankfully it improved on the following: "Ride Your Pony,” "Knock On Wood,” and “Tell It Like It Is,”(I guess it was here that the absent Aaron would join his brother on stage. Did he know that the vocal microphone was not working properly and stayed home?) "Bo Diddley, Part 1 and 2," "La La Means I Love You,” “Hold On, I’m Coming,” “If I Could Build My Whole World Around You,” "Going OutOf My Head.”

The atmosphere in the room was fine and everyone seemed to listen very attentively.

This was the start of the Meters, but I saw the other members as accompanying musicians and did not ask for their names. They used the same instrumentation as Booker T \& The MGs (guitar, bass, drums and keyboard-organ). But I have always thought 
that Booker T. was better and even Chicago's Alvin Cash \& The Crawlers (or Registers) often managed to surpass the Meters. The Neville Sounds were a soul-influenced cocktail jazz group that reminded me of the Ramsey Lewis Trio or the Young-Holt Unlimited group. They were good but not that exciting.

Art (4710 Chestnut St.) was born in 1937 and played the piano and organ. His group, the Hawkettes recorded Mardi Gras Mambo in 1953 for Chess. Every year at Mardi Gras it was released again and played on the radio. In 1957 he toured half a year with fellow Specialty Records artist Larry Williams. Cha Dooky Doo sold well, but Art was drafted into the Navy (1959-61) and was unable to follow up the success, and Aaron took over Art's group.

Art's follow up on Specialty was “Whiffenpoof Song.” In 1961, his Instant record “All These Things” did well.

Presently he had a contract with Sansu and Bo Diddley, produced by Allen Toussaint, was the first record and to be released on the Bell label. Allen would produce his future discs, too. When Art and Aaron performed together Aaron did the ballads while Art did the rock and tougher soul songs.

Art told me that after 15 years of "paying dues" he felt rather hardened and tempered. If their next single Bo Diddley didn't sell he thought about leaving show business for good. I heard the song live and Marshall Sehorn played a demo at the Sansu office. Marshall believed in the song, but I didn’t. In England every R\&B group had played it on stage. It was worn out and 
Art's version was no better than all the others or Bo Diddley's original.

I was therefore both happy and surprised that Art remained in the industry, and that the Meters had international success. When talking to him later I realized that he was not a great optimist that so many other artists are.

At Ivanhoe, I was told that Irma Thomas would be at the Sands this evening. It was a large dance hall that lay at the outskirts of town at Causeway Blvd. in the Jefferson area. I took a taxi to get there on time. It cost \$3.50. Irma would appear there at $11 \mathrm{pm}$.

But I found out that it was tomorrow that she was going to be there. Taxi fares were beyond my budget limit, and in New Orleans they added a dollar extra when you entered a new district.

I hitchhiked back with a Puerto-Rican man who told me that he had a relative who was playing at the Dew Drop, and he drove me there. The Dew Drop was as deserted now as the day before. At the bar sat a small group of men drinking heavily, but Huey Smith was not here tonight either. The hottest tip was that Irma Thomas was at the Shadowland, tonight.

After a very brisk walk to 1921 Washington, I found the Shadowland to be full of people. In one corner extra tables had been set up for a birthday party. The orchestra had a break but soon members and singers lined up on stage. It was:

Tony Owens

Johnny "Scarface” Williams 


\section{Dave Bond}

Plus the Toronados orchestra.

Tony Owens was a powerful singer and he did fine versions of: "When Something's Wrong With My Baby," "Funky Broadway," "Wishing, Waiting, Hopin””

He was born in New Orleans in 1947, and had recorded the following songs for Soulin’ Recording Co:

“Wishing, Waiting, Hopin’,” “I Got Soul,” “I Need I Need Your Love.”

(4121 Eve Street was either Tony’s or Soulin’ Records address.)

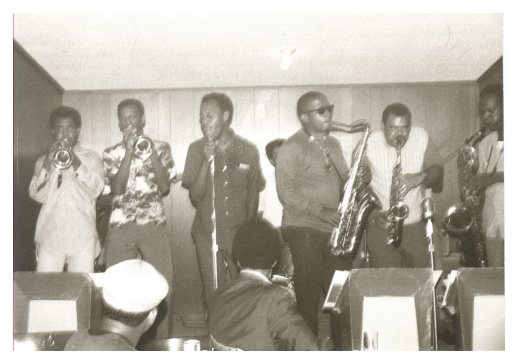

Johnny Williams at Shadowland

It was time for Johnny Williams. He had been with the Clowns and later had his own group called the Tic Tocs. A scar in his darkskinned face disfigured him a little and had given him the nickname "Scarface.” He looked like a person you should not argue with or pick a fight with. I dared asking him where Huey Smith was, but he had no idea.

He sang two songs this evening: "What'd I Say” (Ray Charles), and "I'll Go Crazy" (James Brown).

And he did it brilliantly! This was the type of soul music I really 
liked. (It was a nice change to the bland cocktail soul of the Neville Sound.)

The Toronados Orchestra were besides bass, guitar and drums a five-man horn section - with three saxophones (alto, tenor and baritone) and two trumpets. They did an excellent job and the soul riffs were perfect. It was simply a great orchestra!

In the intermission between Tony Owens' and Johnny Williams' sets I was sitting by the bar. I saw a woman who seemed as much at home in the kitchen as serving and talking to the guests. I suddenly recognized her: It was Irma Thomas!

She quickly explained that this was her husband's club. He was also her manager, and The Toronados was her orchestra. Her old orchestra - The Royals - had been replaced.

This was her night off and she had not planned to make an appearance tonight. She was the cook and the head waiter - and perhaps even washed the dishes ... But eventually the prayers from me and the birthday party got her up on stage.

Her guitarist, Dave Bond began with Sweet Sixteen and another BB King number. Then Irma took place on stage and sang a duet with Dave:

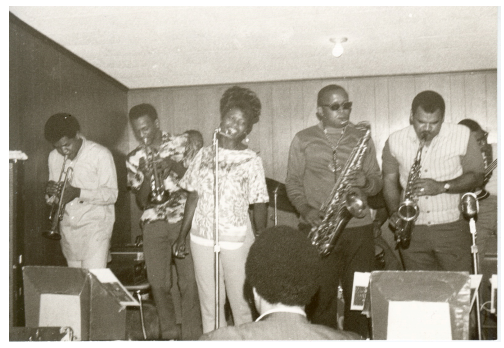

Irma Thomas at Shadowland

"Nothing Like The Real Thing" (Marvin Gaye \& Tammi Terrell) and then she did many current soul hits like: “Good To Me(As I 
Am To You)" "Nickey Hookey," "Knock On Wood," "Dr. Feelgood,” “Think,” “Ain’t No Way,” "I Heard It Through The Grape Vine,” “Tell Mama,” "I’ve Never Loved A Man,” “Respect.”

Then Dave Bond's finished the set with a guitar blues.

Sure, Irma was great and her voice in top form. But why did she only sing other people's songs? The only exception was “Good To Me," an Otis Redding number, which she had recorded on Chess.

Why had she been reduced to an Aretha Franklin cover-singer without a repertoire of her own? I could not hold back my disappointment. Irma replied “If I don’t sing Aretha's songs and other current hits, people will be dissatisfied.”

But she promised to compensate me the day after at the Sands. Our conversation ended as Irma had to serve her guests ...

Irma's guitarist Dave Bond was born in Coles, Mississippi on August 1, 1937. Dave and another guy (Doug) are behind Doug \& Dave on the Satin label. They sang on Going Steady / Let's Monkey Zoo / Do not Know Much About Love / I’m Lonely.

This had been a very successful day. Suddenly all the pieces had started to fall into place in New Orleans. I walked all the way home.

Friday, July 19, 1968

I went to Sansu Records again. Allen was not there but Aaron Neville played table tennis with his brother Cyril and I watched. 
While waiting, suddenly a man knocked on the open window I was sitting by. It was Eldridge Holmes and he was heavily drunk or high already at mid-day. But still more friendly than unpleasant.

A serious interview was not possible, but he told me a long story that he had been good friends with both Otis Redding and Sam Cooke. He missed them very much and became quite tearful. He was a high school drop-out and was renowned for rupturing his pants on stage.

His musical background was both spirituals and hillbilly. His favourites were first and foremost Fats Domino and Professor Longhair but also Hank Williams. He started singing in 1953 and became the lead-singer in a gospel quartet for two years (1955-57). In 1957 he crossed over to R\&B and joined the group the Small Royals where he sang both lead and background.

Nowadays he used to sing background vocals behind Lee Dorsey on all his Sansu recordings and he also played piano and drums. He had made a solo record on Alon: "Poor Me" / "C.C. Rider.”

He asked me to write down the name Phil Ludermann - maybe it was his agent or manager, and Eldridge lived at 2039 Reynes St. apt. 3, N.O.

After a few hours Allen Toussaint suddenly appeared. He was busy with arranging a song. But he sat down and we talked for a while. I understood that he mostly worked at home with arranging and composing. He was difficult to interview. He was 
certainly not unwilling or unkind, but he did not understand that what he said could interest me. My enthusiasm for Professor Longhair was even more difficult for him to grasp. "Professor Longhair is an excellent pianist, but dull and uninteresting as a person,” he said. I always asked those I met in New Orleans about Longhair but the opinions I've had so far was not encouraging.

Allen was born in 1936 in a very musical family. When he was 15 years old, he had his own band - The Flamingos - with among others Snooks Eaglin on guitar. Then he worked with Earl King. Towards the mid-1950s he began to sit in on various studio sessions. In 1957 he replaced Huey Smith - who had a hit with "Rockin 'Pneumonia and the Boogie Woogie Flu" - as pianist in Shirley \& Lee's touring band. He was touring with them for a year. He made an LP for RCA in 1958 ( "The Wild Sound of New Orleans” by Tousan), and a few singles for Seville. At this time he used the artist name Al Tousan.

When Allen described himself as a pianist, he modestly used the word "imitator." To illustrate this, he said that he played piano on some Fats Domino sessions, when Fats had to concentrate on the vocals. Which songs, he didn't want to say. Then people will start listen, compare and start talking. But it was "quite a few."

He also played piano on Jimmy Clanton recordings. "I can write a song in 15 minutes if I have to. That's how I started working with different artists who were in the studio to record." When he composed he heard the song, the lyrics and all instruments in his head. When he went into the studio, he knew exactly what he wanted - and it can be annoying for some artists. Which 
Betty Harris had already confirmed in Miami. She had felt that she had no freedom at all to sing as she wanted. But it would be impossible to surpass what he had achieved on songs like “Nearer To You," "What Did I Do Wrong” and "I Can’t Last Much Longer.”

Something Allen constantly returned to, and tried to explain to me was that the origin of the New Orleans sound and rhythm really came from The Second Line Rhythm.

The foundation is the 2/4 rhythm - with the emphasis on the second and fourth beat. It originated and grew in the big parades during Mardi Gras and at funerals. It was in the second line of people at the funerals that people danced with this special syncopation. He always writes with the 2/4 rhythm in mind (not 4/4). He pointed out how clearly you can hear it on recordings with Fats, Smiley, Professor Longhair, Huey Smith, Lee Dorsey and others.

Allen promised a meeting tomorrow and we parted with half a promise that then he would certainly have gotten hold of someone to interview - Professor Longhair, Huey Smith or Curley Moore ... I could reach him on the phone: 524-3262 , which was the number to the Sansu office.

The Sands was quite far outside the city center and I took a tram there. Halfway there I had to change. The destination was not Desire - as in the play A Streetcar Named Desire - by Louisiana’s great playwright Tennessee Williams.

The Sands was packed. It was a full house with almost 50\% 
white youngsters. It became an amazing and unforgettable evening when Irma, this brilliant singer, sang her best songs accompanied by her Toronados.

"It’s Raining," "Breakaway," "Ruler Of My Heart," "I Need Your Love So Bad," "Time Is On My Side" (covered by the Rolling Stones), "Without Love."

I forgot to take notes of all songs as I was completely absorbed by the music. She also made covers of Aretha Franklin songs and Etta James’ “Tell Mama,” and a few songs I did not recognize.

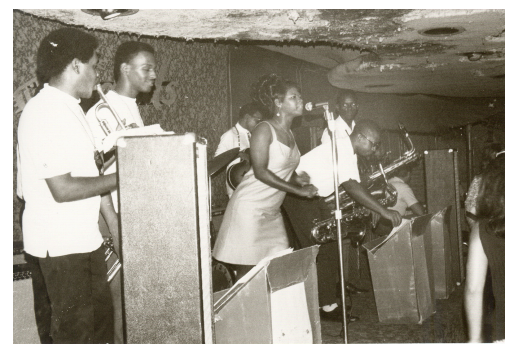

Irma Thomas at the Sands

My favourite that night and one I specifically asked her to sing was "Ruler Of My Heart.” Irma told me that she was still a little disappointed that Otis Redding's "Pain In My Heart," a remake of Ruler, had sold better than her own original. It was arranged by Allen Toussaint and he played the piano.

Afterwards, we talked about her England tour. All had been very kind and she was so happy about the warm reception she received already at the airport. Her fan club with Dave Godin up front had welcomed her with a banner and the text "The Rose of New Orleans.”

The first performance was at the Flamingo and when she sang 
the evening's second song “It's Raining” she began to cry. It spread from the two front rows all the way to the doorman, who could not hold the tears back. Irma asked me to say hello to Dave Godin and the fan club in England. I had met him the year before in his record store "Soul City," on 21 Deptford High St, SE8 London.

He had also started the record label Deep Soul that released songs like "Go Now" by Bessie Banks (the original for the Moody Blues cover). Indirectly Dave became the first prophet of the rave-party.

In the northern coalfield areas of England people celebrated the holidays with so-called “All nighters” - non-stop dance parties that lasted all night to Northern Soul music. Dave reported this in the magazine Blues \& Soul and he contributed to the genre by releasing old soul dance records with for example Billy Butler and Major Lance on his own label.

George Orwell had described this depressing district in his reportage Road to Wigan Pier, which came out before his classic novel 1984. But at the Wigan Casino, it was soul music all night that mattered now. The work in the mine was completely forgotten.

Irma had eight children - four of her own aged seven to twelve years and four in their teens that her husband had brought with him. They had married quite recently. She had been an only child, and described herself as rather spoiled in a family that had no show business contacts and interests. She seemed like a very kind, motherly woman. Sometimes I've wondered if she 
had not supported the men she has been married to. She worked at and brought in the money from the Shadowland although she said it was her husband's club. Ten years later she presented her new husband and manager, dressed in super-fly paraphernalia. It strengthened my conviction that she, like many big female stars (Aretha Franklin, Whitney Houston, Billie Holiday, Etta James and others) often were surrounded by men who lived well on the wife's earnings.

Irma was born in 1941, and before she got a record deal, Tommy Ridgley, bandleader and singer, took her under his wing (1957-). Then she was contracted by Ron (59-61), Minit (1961-), Imperial, Chess (67-). On stage she was accompanied by the Royals and Eldridge Holmes sometimes opened the show. She had also worked with James Brown in 1965. But he did not like that other artists were appreciated and received much applause. He shortened her performance and made changes in her program. So Irma left him.

Currently, she performed at many different universities and called the University of Mississippi in Oxford, and University of Alabama in Tuscaloosa her second homes. It was different there than at the Apollo theater. All were silent and applauded vigorously when she stopped. But at the Royal in Baltimore, she got stage fright for the first time in his life. She had heard that the audience threw tomatoes or booed the artist off the stage if they did not like them. Her knees shook and her voice was just a whisper. When no tomatoes came flying she found herself again.

Now she recorded for Chess at Rick Hall's Muscle Shoals studio. They had released "Good To Me" and "Women Will Do 
Wrong.” She was hoping for a new spring; as Etta James who recorded "Tell Mama” there. If her records started selling again, Minit Records, that had 12 unreleased songs in their archives, would definitely release them, she thought. Some of the tracks were absolutely wonderful.

Barbara George (who had a big hit with I Know at AFO in 1961) never showed up at the Sands. Irma was disappointed. She had arranged this gig for Barbara. That's why some artists fell into oblivion; they misbehaved, said Irma.

Irma also said that Shirley was no longer singing with Lee but with Alfred (Swift?), who is better known as Brenton Wood. Before that, she sang with Jesse Hill.

It had been an unforgettable concert with a very generous artist, where she, the repertoire and the orchestra all receive the highest rating possible.

Tony Owens also sang a few songs and added attraction this night was Oliver Morgan. He sang:

"You're Looking Good” (Pickett) "Funky Broadway” (Pickett) “It's The Same Old Song” (4 Tops) "Kiss Tomorrow Goodbye” (Danny White) "Try Me" (James Brown) "Knock On Wood” (Eddie Floyd) “Soul Man” (Sam \& Dave) and his own “Who Shot The La La.”

In the finale, he walked around with an umbrella raised above his head. The audience followed in his footsteps as he sang “When The Saints Go Marchin’ In.” It was a reference to the Mardi Gras carnival as well as the funerals that took place in New Orleans, and a nice ending of a very satisfying evening. 
Oliver, also called "Nookie Boy”, had recorded approximately half a dozen records and wanted to stress that his biggest success was "Who Shot The La La” (GNP Crescendo).

The song was about Lawrence "Prince La La” Nelson's death in 1963. He was the brother of Walter "Papoose" Nelson. Herman and the Hermits were to record this song, but for some reason it never happened. Oliver recorded for Seven B. since a few years back. He drove me back to the hotel. Then he continued to his own residence at 1512 Tennessee St.

Saturday, July 20, 1968

I stopped by at Sansu, but Allen Toussaint was not there as usual.

Only when his partner Marshall Sehorn came back things started happening. It was a warm and sunny day. I went back to the hotel and transcribed my notes.

In the evening I went to the Nite Cap. I was told that Willie Tee might be there. I thought he was one of the more interesting new soul artists alongside Diamond Joe and Curley Moore. But it was a disappointing evening with substandard artists that I did not care to interview or write down their names. The atmosphere was not good. The other guests thought that I was suffering from Jungle Fever - that I was chasing black women. It was full of people and the Dixie beer flowed, despite the radio station WYLD's boycott. I talked with a young black woman - a few years younger than me, who already had two small children at home. Anyway, I didn't feel welcome. It was better to visit the clubs during weekdays and not on weekends. 
Sunday, July 21, 1968

I woke up very tired. The oppressive heat made the hangover worse. I went down to WYLD, but found no one to talk to. In the afternoon I walked along Bourbon Street. It was a melancholy feeling there. But I stayed for a while and listened outside the wide open doors to a bar I had not visited before. There a pianist hammered "Lawdy Miss Clawdy" on the piano while one of the guests, a white girl, danced on a table. It was good. Then the show ended and I went on. Who was the pianist?

It had been a busy week so I continued to correct my interviews while I was listening to the radio.

These are the best songs I heard in New Orleans. Most were new recordings but some oldies were played as well. An * asterisk marks my favourites.

"My Love Gets Stronger" - Tommy Ridgley, "You Were Meant To Me" - “Crume” Brothers, "Stone Good Lovin'” "Fly Me To The Moon” - Bobby Womack(*), “Get OutOf My Life Woman” - Allen Toussaint, “I’m Just Not Ready For Love” - Irma Thomas, "You Were Meant For Me" - Soul Brothers, (probably the same song as with the “Crume” Brothers), "I Know I Got A Sure Thing”-Ollie \& The Nightingales(*), “Memphis”-LonnieMack(*), “I’m Your Man”-Bobby Taylor \& the Vancouvers, "Lean On Me” - James Fox, “Lady Madonna” - Fats Domino, “Darling Someone Somewhere Loves You” - Lee Charles, "Dear John” - Jackie Moore, "Never Never Leave Me" - Alice Clark, "People Got ToBeFree" - Young Rascals, "The Snake” - AlWilson, "Hold My Hand” - 
Bobby Hall, “The Girls Can’tDo What The Guys Can” Betty Wright, “I Ain’tParticular”- Johnnie Taylor, “I Don’t Want To Cry”-Chuck Jackson (*), "Pickin' Party 1" (instrumental), “The Mule” - James Boys, "Just A Matter of Time”-Brook Benton.

Monday, July 22, 1968

I walked past Sansu. The receptionist recognized me, and said that Allen was not there but that Triple Souls were recording at Cosimo's studio. I continued to Camp Street.

Garland Hilton, a red-haired, bespectacled, blue-eyed soulsinger was recording for Seven B.

The record company was named after "the seven hundred block on Camp Street” where Instant and Seven B. were located. This day Garland was the responsible producer, arranger, technician and composer. He also played the organ, but not on this recording. (He had a female organist in his usual band.)

There was no time for an interview. But he said that he had his own big band (when he added four extra men to his regular eight-piece band). He had recorded three singles so far. The first never came out. Return of Billy Joe was released on White Cliffs. This rock song had everything, including water splashing when Billy Joe jumps from the bridge and landed in the water.

His third came out on Instant: "Instead of Just A Friend” / “A Bin Of Woe.”

Garland definitely belonged to the New Orleans B-team. But his 
opinion of himself was much higher. After a while I got tired of listening to the recording and instead went around in the house and looked around. It was a strange old warehouse that was deserted and only contained old junk and large paper bags, and boards and building materials. (The big plans to create a center here for recordings and distribution of New Orleans music, had failed.)

This house was a monument to that failure.

I met Sena Fletcher while on my way up to the first floor. She had finished singing and was on her way to Joe Banashak (1923-1985). She asked me if I wanted to join her. She had done another job for him but without getting paid yet.

Joe Banashak's office was nearby on the fourth floor at 715 Camp. I also wanted to meet him. Joe was both surprised and a little upset when Sena appeared and demanded money, but after a while he paid her nicely.

Sena was not only sweet but also determined and had a mind of her own. When she left, I interviewed Joe. He seemed slightly absent minded and not quite fit and appeared to run at half speed. He said that he had high blood pressure. It was probably suppressed with sedatives then.

The record company had an office room and a large storeroom where the singles were stacked in piles on the floor surrounded by bookshelves on the walls. It might be from 10 to maybe 100-150 items in each single-stack. To emphasize what songs he was talking about, Joe picked up some and gave me, like 
"Pass The Hatchet pt. 1-2" - by Roger \& The Gypsies (with Eddie Bo - vocal) or the milestone "Good Thing Goin'”- with the Rainbows.

Minit was launched in 1959, when the first record was released. In 1963, when Joe became ill, the company was sold to Imperial. They had contracts with all major New Orleans performers. In fact all artists had started with him, except the Showmen, who came from the East Coast.

In 1961 he started Instant and in 1963 "Land Of 1000 Dances” with Chris Kenner was released - my own favorite recording on that label. He had a couple of tracks in the can with Lee Diamond (best known for Hattie Malatti: an answer disc to Larry Williams Short Fat Fannie / Bony Maronie), and dozens of Irma Thomas recordings. He had actually released a single with her on Bandy after her transition to Imperial called "For Goodness Sake” / "Whenever” (1963), both written by Naomi Neville i.e. Allen Toussaint. He had released six records with Art Neville on Instant.

The publishing had also been successful. Chris Kenner's "Land Of 1000 Dances" that had been recorded by 60 different artists and "Something You Got" was recorded by 55 artists. "Even I Like It Like That” was much recorded. But outside USA his artists sold very poorly.

Joe said that the New Orleans sound had not been particularly appreciated even if some songs had sold a million. In 1960-61 artists and record labels came from other states to record, but 
these records were often poorly recorded and produced, and the best musicians were not always hired.

"Ride Your Pony” started a small New Orleans revival in 1965, but now the interest had cooled again. Joe thought that the sound had become too complicated, and perhaps not easy to reproduce. Allen Toussaint had started on its own as an independent producer and arranger in 1965 with "Ride Your Pony" along with Marshall Sehorn. Before that, Allen and Joe Banashak had a handshake agreement. I guess Joe had not been able to find another producer like Allen Toussaint. Eddie Bo, who was hired in 1965, was not in the same league.

Joe had sorted the stacks of $45 \mathrm{~s}$ on the floor after the names of the record labels:

There was Seven-B (with, among others Barbara George, Eddie Bo and Inez Cheatham). There was Alon which started in 1962 with Willie Harper and New Kind Of Love, and also Eldridge Holmes. Allen Toussaint had released a solo record on Alon: "Go Back Home" / "Poor Boy," that did not sell even though it was very good and all the DJ's played it. Allen Toussaint's LP on RCA Victor "The Wild Sound of New Orleans" had been leased from Seville Records, said Joe.

Tune Kel was formed in 1967 while the Busy Bee was a pop brand. Then there was Instant and Bandy and then some more labels. He distributed Lanor Records - where Charles Mann had some pretty good sellers. Joe had had a few minor hits in recent years: "It Do Me Good" with the Pitter Pats that Huey Smith produced. In 1966, Roger \& The Gypsies recorded "Pass The 
Hatchet," but because of the Watts riots (in Los Angeles) it was not played on the radio. A recent hit was the "Rainbows Good Thing Going,” which was written by Eddie Bo. We also talked about tougher songs like Boogie Jake's Early Morning Blues (Minit) and “Screamin \& Moanin”” with Diamond Joe.

He had hopes for Pearl Edwards new disc, and he was going to record Sam Alcorn: a trumpeter in the pop-soul style from a well-known musical, trumpet family.

He also planned to record Irvin Ross (also known as Edward Ross) aka Little Buck, the lead singer of the Hueys.

Even if they could make records that sound like Aretha Franklin he preferred the old, simple New Orleans sound. He also had plans for Chris Kenner (1929-1977; born in Kenner) who still sang exactly as he always had, according to Joe. Next record was going to be a dance song with a "Hold On I'm Coming” intro.

It had taken a long time for "Coo Coo Over You” with the Hueys to become a hit. Only after five months had it really begun to sell. Huey Smith was behind the group, and now he planned to do an instrumental LP with Huey. Here I interrupted him - Did he have Huey's phone number? Certainly, he said, and went into the office room and looked it up.

Joe had a completely different approach than the people at Sansu Records. He seemed to release as many records on as many brands as possible in the hope that someone would stick. He distributed a lot of small labels too. In the process he worked 
with the A, B and C-team of artists and producers - in fact with almost anyone who had something going on.

Joe probably had agreements with artists and producers where they took a number of records instead of money. Thus minimizing his own expenses. I guess many artists funded their own session and got the money back when those records had sold well enough. But he seemed to have lost his artistic grip. Maybe he was not even involved in the studio anymore. I preferred Sansu's perfectionist production of records. Tamla Motown had a panel and quality control and only released records above a certain standard. At Stax-Volt they avoided mediocre material, otherwise program directors and DJs might get tired of the label and not even listen to a record. When that was the case here, Joe probably just started a new label ... There were many more that I didn't notice: Polytex, IMA, Flowerpower, AIR, Local, Channel One, Invicta, etc, etc.

With a small stack of $45 \mathrm{~s}$ in my hand, I went to Bourbon Street.

First to the Court of Two Sisters and talked with Roosevelt Sykes for an hour while Smilin' Joe played. Then continued to the Ivanhoe piano bar where Allen and Marshall Sehorn sat and listened to their latest rising star. Marshall had just returned and Allen introduced him. We listened to a set with Art Neville \& The Neville Sound and then continued to Club 577 and Clarence Henry. 


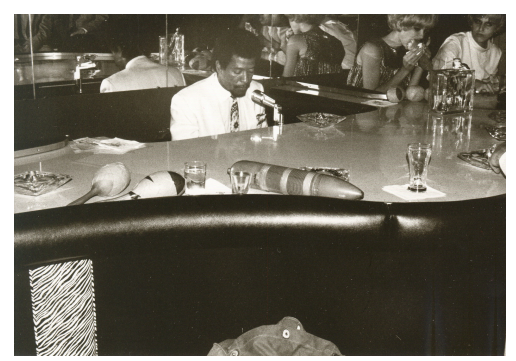

Allen Toussaint, New Orleans

Marshall obviously wanted to reconnect with the New Orleans atmosphere and we went to a place nearby that played Caribbean and Latin music. Allen sat down at the piano and entertained the audience with South

American rhythms. Which now included Fats Domino who had entered in his white suit with a silver stained tie. He also had a star-shaped watch studded with jewels, and similar, though smaller rings on his fingers. It was pure bling and Fats seemed a bit sour when I greeted him. I wondered if it was because I had preliminarily booked an interview with him between performances at 10:30 pm on Saturday. I had spoken to his manager about this, but everything was so messy that I did not think they cared about it. Maybe I had been influenced by the no-show at Sansu by Allen or that Aaron never appeared at the Ivanhoe.

Perhaps Fats was also annoyed that I socialized with the men who created the New Orleans sound of today and who had replaced Fats as the number one hitmaker in town.

Marshall was in a good mood and wanted to buy me a drink. I suggested a Mint Julep (Immortalized by the vocal group The Clovers, and New Orleans pianist Jelly Roll Morton who had recorded his own composition Mint Julep in 1929.) It was served in some places and looked very tempting. It was outside my normal cash flow. Unfortunately, this place didn’t serve it. 
It had been an interesting day. During the conversation, I understood that it had not been without problems for Allan to leave Instant and start cooperation with Marshall Sehorn. But he probably saw that Joe Banashak was on his way down and could not take care of business as before. When Marshall bet his last penny in 1965 on a session with Lee Dorsey and Ride Your Pony, both came out as winners.

There had also been legal problems with Robert Knight and his recording Everlasting Love on the Rising Sons label in 1967. I do not remember the details and later that night I had difficulty to understand Marshall, who became pretty drunk. While Allen was considerably more collected.

Tuesday, July 23, 1968

This was my last day in New Orleans.

I ordered a seat on the plane to Houston the next day and then dialled 897-2412. Huey Smith answered. At first he was a little suspicious, but then he understood what I wanted. He had a rehearsal with his group The Hueys in the evening, but afterwards he wanted to meet me.

Then I contacted Marshall Sehorn. He had arranged meetings with Curley Moore and Lee Dorsey. In the evening, I was picked up by a recreationally dressed Curley Moore at my hotel. He drove a rather tarnished Cadillac which seemed at least five years old. I had only heard his song “Don't Pity Me” on the LP Bell's Cellar Of Soul. It was good. Both Marshall Sehorn and Allen Toussaint met us in the Sansu office. 


\section{Curley Moore (1943-1985)} was born June Moore in New Orleans. He started singing with friends in the streets and already at eight or nine years of age performed for pennies. Later he sang in the choir and sometimes as a soloist at the New Hope Baptist Church. In 1955, at age 12, he formed his own group, the Blue Jays. They were, like most children, very much inspired by the singing and dancing of Frankie Lymon \& The Teenagers. Otherwise, his first

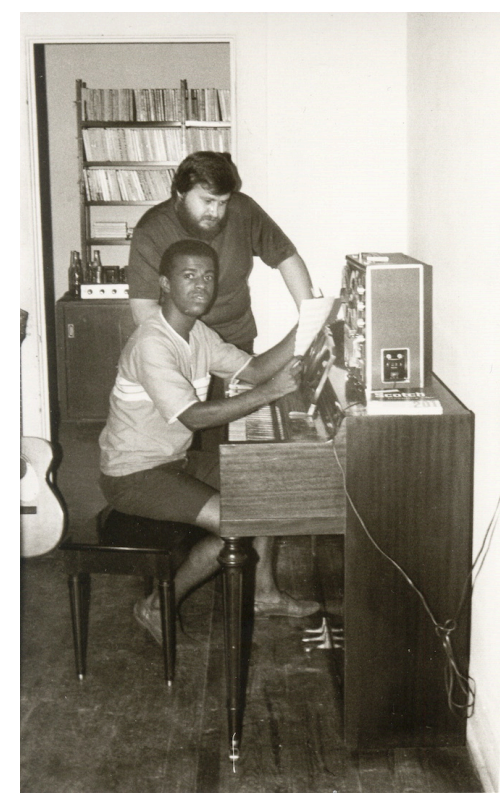
big inspiration was the singing cowboy Roy Rogers' TV-show. The family that owned a TV, in the poor neighbourhoods where Curley grew up, then had their home invaded by children.

The Blue Jays tried to create a name for themselves at talent shows. Curley was discovered by Ace Records and did a lot of background singing and also two records (1956-57), which were released under his own name at Ace: They Gonna Do / Tried So Hard (written by Joe Tex) and The Second Line / At The Mardi Gras. They did not sell but he began performing as a solo artist and tried to get work within and outside New Orleans. The other members of the Blue Jays had tired and worked outside the 
record industry. He remembered that Willie Tee (Turbinton), was another struggling artist who did not give up.

Eddie Bo took Curley under his wing and often made him sing as the opening act. Curley sang everything from Nat King Cole to rock and roll while he was still in school. Curley was also one of the best young dancers. In 1959-60, he became one of the Clowns and toured with Huey Smith for three years.

The other Clowns then were, according to Curley: Bobby Marchan, Billy Brooks, Johnny Williams, Eugene Harris and Curley Moore. Huey was the sixth member but he very rarely sang. Curley could be heard on several of The Clowns discs like “Pop Eye,” Tu-Ber-Cu-Lucua and The Sinus Blues," “Havin’ A Good Time.” He was not particularly pleased with the Clowns singing technique. “To shout 'I wanna jump' or 'Popeye' at times, is not singing.” But he made good use of his dancing ability.

Curley also said that Joe Tex was on "For Crying Out Loud," although he didn't sing lead. (In 1969, Joe told me that he had not been recording with the Clowns - but maybe he never had a chance to search his memory.)

Joe Tex was more or less stranded in New Orleans during the second half of the fifties and made a brilliant Little Richard imitation - "You Little Baby Face Thing" - on Ace that was also released on Sue Records in England.

In 1962-63 Curley left The Clowns. "They were going down when I joined and had hit bottom when I left,” said Curley 
laconically. He began to sing solo again and 1965-66 was contracted by Nola, where he stayed for two years. His first song, written by Earl King, became a hit - Soul Train. He was nicknamed Curley "Soul Train” Moore. Bobby Reno also made a successful cover of "Soul Train." The follow up "Feel That Groove” was never released. In 1966 he was contracted by Sansu. So far, they had released three records, all local but not national successes. "Let's Get Low Down, Goodbye” / "We Remember," “Don’t Pity Me.” Curley played guitar, organ, piano and drums - sometimes even on stage. But he could not read music. His own inspirations were Gene Allison, Frankie Lymon, Irma Thomas, Ernie K-Doe, Shirley \& Lee and Jackie Wilson.

Time for photography and Marshall and Curley posed by the tape recorder as if they were working with the next hit single. In the adjacent room Aaron Neville and Allen Toussaint played table tennis. I took the opportunity to ask Aaron to take down the Lee Dorsey gold disc (Working In The Coal Mine) hanging on the wall - and pose as if it was his own million seller "Tell It Like It Is.”

Marshall was picking up steam. On a small shelf on the wall were all Sansu singles and he gave me some with my favourites (Betty Harris, Diamond Joe and others). He put my name on the mailing list. Marshall, who smoked cigars, and was rather corpulent and didn't seem to exercise much, gasped for breath during these exercises.

There was another difference between Sansu and Joe Banashak. While Joe had his own distribution of discs that filled a large 
storage room, at Sansu they had only a couple of meters of shelves with different compartments for maybe 25 different singles. The same was the case with Stax Records, but they also had LPs.

Marshall had arranged a meeting tomorrow with Lee Dorsey.

It was close to midnight. Marshall and I went out to his Cadillac - much newer and fresher than Curley's. He drove me to Huey Smith and we talked on the way.

Marshall Sehorn (1934-2006) had started by working for Bobby Robinson and his Fire/Fury Records in New York. Then he started his own labels - Sea-horn and Neptune - and recorded artists like Wilbert Harrison. He said that Smiley Lewis taught Fats Domino a lot.

We were now in the neighbourhood of the Dew Drop Inn. Marshall sat for a while and waited in the car to make sure that everything was OK. But he did not follow me inside and said hello to Huey.

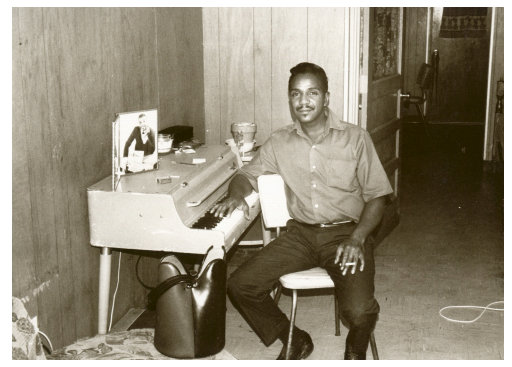

Huey "Piano" Smith at home

Huey Smith lived in a small two-room apartment at 1913 7th Street (apt.7) with his family. The two children were sleeping and Huey's wife, a beautiful, slim woman, a few shades lighter in complexion than him, greeted me before she went to 
bed in the back room. We sat in the other, front room. There was a piano with an old publicity picture of Huey. On the walls he had pictures from his career. There were no signs of prosperity or abundance in the apartment, but everything was in good order.

The interview with Huey was the best one I did in 1968. He had an excellent memory. (An article was published in Shout No. 70 (October 1971). This number was called the Huey Smith special).

I had bought an English Sue LP with Huey Smith \& The Clowns a couple of years ago. It was one of my most played records. The irresistible rhythm, the brilliant instrumental efforts and the nonsense lyrics placed Huey alongside Chuck Berry when you needed to get in a good mood at no time.

I had a couple of singles with Professor Longhair, and Huey had continued that tradition in a most credible manner. In fact Huey was the Professor's best pupil.

Huey was born January 26, 1934 in New Orleans and began to play the piano early. Then, Dixieland and big-band jazz was the most popular forms of music in New Orleans. This era was followed by Smiley Lewis (guitar) and Professor Longhair (piano). They were the most popular and trendsetting local R\&B artists. Huey formed a R\&B combo - the Joy Jumpers - when he was thirteen or fourteen years old.

One evening, Professor Longhair came into the room where Huey played. He took over the piano with Ain't Got No Hair and Huey did not play anymore that night because the professor 
was so good. But he began to practice more. Besides Longhair it was Ray Charles who really inspired him to play the piano. This was around 1948, during Ray Charles club-blues career, when he was inspired by Charles Brown. Huey felt that if Longhair had been managed better, it had been him and not Fats Domino, who would have sold 78 million records.

Huey dropped out of high school in 1952 when he began playing with Guitar Slim (1926-1959), who was later discovered by A \& R man Johnny Vincent, who worked for Specialty. Huey said that he was playing on Guitar Slim's Imperial session and on the “Feelin' Sad” session on Bullet (J-B 603), but pointed out that it was Ray Charles, who played piano on "The Things That I Used To Do.”

I had not yet heard Guitar Slim or his gigantic hit. His records were not available in Europe. It was only the next year I found it on an album compiled by Alan Freed on End Records. Otherwise I would probably have left no stone unturned getting Huey to say more about one of blues history's most colourful and self-consuming artists. Apparently they had met and started playing together already in 1949-50 at the Dew Drop. I was grateful to have briefly visited this holy place of $R \& B$ where all important R\&B artists had performed.

Huey became a sought-after session pianist. But Johnny Vincent had the habit of writing "featuring Fats on the piano" on the Ace-label, when in fact it was Huey Smith who accompanied for example Earl King. In some cases, as Ace 520: “Mother Told Me Not To Go" it is obvious that Fats is in fact Huey. On other songs not even Dave Bartholomew could always separate us, 
said Huey. Dave thought that Fats had played on two sessions, or one more than he was contracted for. But it was Huey on the other. That enhanced Huey's reputation as a studio musician.

Many like me have probably enjoyed Huey's fabulous piano solo on Smiley Lewis's “I Hear You Knocking” (another immortal New Orleans recording). Huey reused the same piano solo, both on its own "High Blood Pressure” and on Earl King's “Those Lonely Lonely Nights.”

"People actually started to complain, but I thought it was a fantastic piano solo,” said Huey. Huey also accompanied Lloyd Price (1954) on Specialty ("Where You At?," "Lord Lord Amen”). Now, almost everyone started recording in New Orleans and Huey said that he was on early Little Richard recordings. I thought that "Slippin 'And Slidin"” was the first, but Huey said it was prior to that recording, and it means that he was on "Tutti Frutti” / "I’m Just A Lonely Guy.”

Huey was the better pianist but they were short of time and had no time to rehearse "Tutti Frutti” so Richard himself played piano on this track at the end of the session's second day. But the other songs feature Huey Smith.

Huey's first record under his own name was "We Like Mambo" - which later was transformed into "We Like Birdland." But he did not sing himself, instead they used a girl's voice. But first it was released under Eddie Bo’s name. He had just left Ace. They only had "I'm So Tired” and needed a B-side. But Mambo sold better, and went to no 1 . locally, and was later released under 
Huey's own name. This was in 1956 and Huey was a studio musician and pianist with Shirley \& Lee’s touring band.

Huey never mentioned that his first record was recorded in June 1953 on Savoy. This company was looking for new talent, and had gone down to New Orleans and recorded a lot of records in a short time that were released without leaving any significant traces in the charts.

Johnny Vincent owned Ace Records and he contracted Huey, who before his next recording session formed the group The Rhythm Aces (The name was used only on one disc.) “Everybody's Whalin'” became a local hit.

Huey was still developing his own style as a pianist. The foundation, of course, was what he picked up from Professor Longhair, his greatest mentor and inspiration, but also from contemporary premier R\&B artists and pianists who performed regularly at the Dew Drop Inn (Amos Milburn and others).

Huey believed that what distinguished him from other pianists and what characterized his own style - was his heavy, rhythmic left hand. Dave Bartholomew told him that he played too technically flawless. He should hit an occasional false note sometimes as Little Richard did. The audience would love it.

The Rhythm Aces consisted of Johnny "Scarface" Williams (who in 1968 had his own group called the Tic Tocs and whom I had seen a few days earlier at Irma Thomas club, Shadowland) and "Sidney Ricksfield." They also appeared on "Rockin' Pneumonia” but were now called The Clowns. Huey had heard 
Chuck Berry in "Roll Over Beethoven” sing “I got the rockin' pneumonia, I need a shot of rhythm and blues." That was the inspiration. The year was 1957, it became a huge success and Huey left Shirley \& Lee. Huey had found his own style, but he needed a more powerful vocalist and engaged Bobby Marchan whose Little Chickee Wah Wah he had previously produced. Many vocalists sang like Dr. John in New Orleans, and Huey did too. But in Bobby Marchan Huey had found a vocalist who could be just as exciting and hysterical as Little Richard, and have the same vocal range and sing both R\&B and Soul. (Richard also covered Bobby Marchan's “Get Down With It” a Gay showstopper.) But unlike Richard, Marchan did not like to talk about himself or be interviewed when I met him in 1978.

After seeing Scarface Williams, I think no one in New Orleans had a better ear for powerful male vocalists than Huey. While the more prejudiced perhaps were shocked that Bobby sometimes appeared on stage in a female dress, white wig and a handbag, he probably was the ideal leader of the Clowns.

Bobby Marchan was heard on the radio that summer with his medium sized hit Ain’t no Reason for Girls to Be Lonely (Gamble Records).

After a few record-releases Huey engaged Geri (Jerry) Hall who became the girl voice on many records.

Earlier that evening Curley had said that the Clowns were five men plus Huey, but that Huey sang very rarely. Huey never talked in detail about the Clown members during the heyday (1957-59). It was obviously quite a lot, but those Huey himself 
mentioned I felt were the main members. (In the Shoutdiscography and article is also mentioned: Junior Gordon, Sid Raphael, Eugene Francis, Aaron Neville, Margie Joseph and Joe Tex.)

When I met Huey again in 1978, Huey added "Kenneth" as a singer on two Imperial songs: "I Need Someone to Love" (5721) and "Don’t Knock It” (5789) and said that Young Jessie, "Thomas" and Huey sings on "Talk to Me Baby" / "If It Is not One Thing It's Another” (Ace 8002) and James Wes on "Every Once In A While” (Ace 672). Huey also said once again that Joe Tex can be heard for on "For Crying Out Loud" (Ace 584) and that it is Joe who sings the line "Cottonpickin '......" . Curley, and Huey sings on "I Did Not Do It” / “They Kept on” (Vin 1024). (Vin was a subsidiary to Ace) and Billy Brooks sings (lead?) on "Pop Eye.”

After "Rockin' Pneumonia” followed a series of fine discs that culminated with the double-sided million seller: “Don't You Just Know It” / "High Blood Pressure.” His records sold well, but when Huey asked for money Johnny Vincent remarked that he had to bribe so many disc jockeys to play the discs that he made a loss himself. Johnny often used to add his own name as cocomposer on the label - "but I wrote all the songs," said Huey. Despite the fact that Huey should earn a lot of money, he was broke all the time. The only money he got by Johnny Vincent was $\$ 2,000$ and a couple of hundred dollars at different times.

Johnny Vincent promised to deposit money into Huey's checking account. But he never did and Huey’s checks for hotel bills of $\$ 20$ and $\$ 40$ bounced back, etc. 
But Huey was not worried. He was “Havin’ A Good Time” and partied a lot. Sometimes he did not show up at gigs and was sued by organizers. He was more concerned that Johnny Vincent focused on the white artists Frankie Ford and Jimmy Clanton. Huey and Geri Hall had made their own vocal version of Sea Cruise but Johnny took away the vocals and put on Frankie's voice instead. This was in 1958.

Huey was deeply hurt by this trick of Johnny Vincent's, but I think the end result was a better song. But had Bobby Marchan taken care of the Sea Cruise vocals it would have matched Little Richard's best recordings.

On stage Huey stood straight up and just played the piano, but he avoided the Little Richard's gimmicks. He never put his feet on the keyboard or walked on top of the piano.

He stood perfectly still, as if he only occasionally hit the keys while the Clowns swapped lead and flew over the stage like dry skins. "We did not sing in harmony like all other groups, but we sold the records" said Huey.

Huey was very proud of his touring band. It was Jessie "Ooh Poo Pah Doo” Hill on drums. Raymond Lewis, who made the original version of "Gonna Put Some Hurt On You," played bass. The sax-section consisted of James Rufus (Gore) and Robert "Barefootin” Parker (Tenor saxes) and Walter Kimble (1938-1988) (baritone sax); later with Fats Domino. Little Booker (alias James Booker) played the organ and piano. He used this band on sessions, except only rarely Raymond Lewis and never Jessie Hill. Instead Huey used the legendary drummer 
Charles "Hungry" Williams (1935-1986). When they needed a guitarist, Dr. John (Mac Rebenack) joined them occasionally in the studio. But the band cost a lot of money and in the long run, he could not keep it together.

In 1959 he began to tire of the hectic pace and took a vacation. When they came back, Bobby Marchan had made a solo record for Bobby Robinson's Fire Records. "What Could I Do” became a hit and Bobby left the Clowns. But Johnny Vincent showed a contract - a forgery said Huey - which revealed that Bobby Marchan was still contracted to Ace. Bobby Robinson had to pay $\$ 15,000$ to turn him loose. (The sum sounded very high. Marchan was not Elvis ...)

In 1960 Huey's contract with Ace expired, and he joined Imperial records. Of his "Behind the Wheel Part 1-2" another group did a cover version with the same engine sound. They released three 45s ("The Little Moron" / "I Need Someone" was the first at Imperial - and "More Girls" / "Sassy Sara”) and recorded eight or nine more tracks never released because Johnny Vincent showed a contract where Huey was still contracted to Ace. Huey was deceived when Johnny asked him to sign a stack of letters to different disc jockeys and placed the contract among them. At other times someone had copied his handwriting. That's why Huey never had a chance to join Marshall Sehorn, who wanted to record him.

Huey had to go back to Ace. He assembled a new group of the Clowns with Curley Moore and Billy Brooks and a little later Geri Hall came back, but only for one disc. (Both Curley and Billy had probably also been with the Clowns before; in 
1957-59.) Geri did not tour with the group which now consisted of only two men plus Huey. Huey had discovered Billy at the Dew Drop Inn, when he was clowning in the bar. Billy had never been on stage before. With the group he continued making jokes, shouted a few lines, and ruptured his pants.

They managed to get decent hits like Having a Good Time, "TuBer-Cu-Lucas And The Sinus Blues” and “Pop-Eye.” Huey had done the background music to "Pop-Eye" in 1957 and added vocals in 1961. It probably sold better than other Popeye discs. Old recordings from the can like "Scald-dog" (1957) and "If It Ain't One Thing It's Another” was released. They toured for another year mostly in South Carolina where their popularity lasted the longest. Now Young Jessie joined the group. Ace released more material but in 1963 the can was empty and the group closed down.

Ace released three LPs: Having a Good Time, 15 Best and T'was The Night Before Christmas. The Christmas album was released only in the Carolinas. When it was played on a TV show (probably in New Orleans) and the DJ heard "Silent Night" in R\&B tempo, he resolutely threw it in the dust bin. It did not sell at all but Huey thought it was a good LP. It contained tracks like “Jingle Bells,” "Rock and Roll Santa,” “Don’t Make My White X-Mas Blue.”

In 1964 all Ace contracts - fake or real - had expired as Huey's lawyer had stipulated that all had to be signed in his presence. He could start again. But it took a while to get back on his feet. Huey survived on radio-play of his compositions. "Little Brother Tom” was broadcasted in Belgium (a song Huey did not even 
recognize when he got the BMI settlement from there). Arthur Conley’s cover of “Don’t You Just Know It” helped too.

In 1964 he founded the group Soulshakers. (This is not the group that recorded Get Hip To Yourself at Loma.) They recorded “Every Once In A While” on the Pitter Pat label distributed by Instant. Pearl Edwards, a girl - sang lead, but the record did not sell so Huey renamed the group Shindig Smith and the Soulshakers. But their “Through Fooling Around” did not sell either. (The Shindig name came from the popular TV program.) Pearl was the prominent figure and Huey played a little theater at the end and fired a gun, etc.

Huey renamed the group the Pitter Pats and they released three records on the Pitter Pat label: "It Do Me Good," "Bury Me Deep," "Baby You Hurt Me.” The first one, featuring Gloria ... and Alex Scott singing, became a local top 10 hit but the others did not sell.

The name was changed to the Hueys. Only Huey and Pearl Edwards were left from the Pitter Pats and a new lead singer, Little Buck was found. They recorded "Coo Coo Over You” and “You Ain’t No Hippie” with Buck as lead for Huey’s own Cooley-label, while Instant released it. "Coo Coo Over You” peaked in February 1968 in New Orleans and was played on the radio in Miami five months later and probably sold well there too. The London label released it in England.

Pearl Edwards sang lead on the sequel “Feelin' Kind Of Coo Coo Too.” Huey wrote and produced. Huey wanted to call the group the Hippies, but felt that parents did not want their 
children to be fans of a group with that name. To further stress this point, they had recorded "You Ain’t No Hippie."

Right now, Huey really wanted a big hit to afford a good lawyer, and once and for all clear up all legal mess with Ace and Johnny Vincent.

Recently, he had heard that a white stranger was looking for him at the Dew Drop. He thought it was someone working for Johnny Vincent or the IRS. But it was me...

It was three o'clock in the morning. We had been talking nonstop for 2.5 hours. Sure, I wanted to hear Huey play and sing a little but his piano was out of order and he did not want to wake up the family. When I left he handed me the publicity picture on the piano.

I think Huey is one of the most original contributors to the black rock \& roll era. He has always been one of my personal favourites. Sometimes he got inspiration from children's playgrounds where he picked up rhymes and chants while they were skipping rope or played.

In 1978 he asked me to turn off the tape recorder when he quoted a couple of dirty lines that had been the inspiration for one of his bigger hits.

I hope that my favourite line from Sea Cruise (recorded 1958): "I'd like to boogie woogie like a knife in the back," was picked up elsewhere.

I never saw Huey as a legal grumbler. Everything he told me 
seemed credible and made sense. He was a has-been in New Orleans but in Europe he was highly appreciated.

Wednesday, July 24, 1968

Marshall had promised to drive me to the airport. Along the way, we should try to meet Lee Dorsey. He arrived a bit late to the hotel but saved time on the way to Fats Domino and Lee Dorsey's houses. I told him about the successful interview with Huey and Marshall confirmed that Huey had a bad reputation and was famous for no show at concerts.

Marshall looked worried when I told him about my meeting with Eldridge Holmes. He had plans for him. He mentioned the song "Now That I’ve Lost You."

Lee Dorsey (1926-1986) and Fats Domino lived just a few blocks from each other. They had grown up together and made music together. Nearby Fats house, we met at one of Lee's sons, Junior. And when we knocked on the door Lee's wife opened and said that he was at his workshop. 


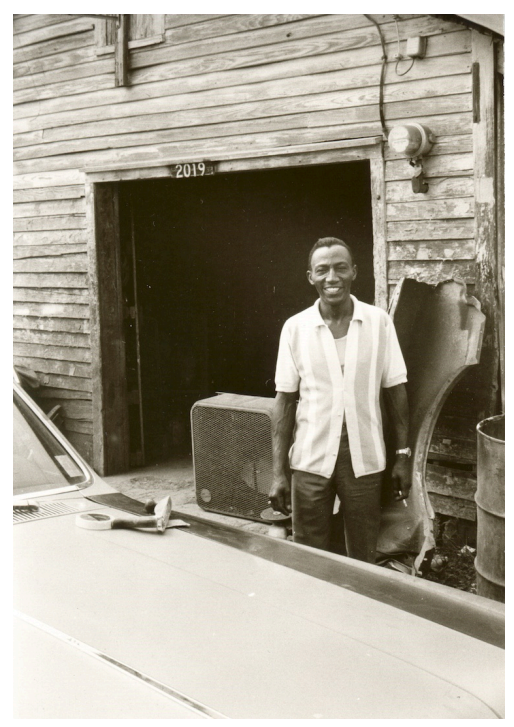

Lee Dorsey at his own junk yard

This was Lee Dorsey's day off and he celebrated it at his junkyard. He greeted us with a beaming smile. He had undergone extensive dental restoration and had new teeth and a lot of gold in his mouth. Lee had his own car junkyard with some 300 used car wrecks from which he sold spare parts. He saw it as a hobby, but made a good living from it. Lee was discovered by Reynauld Richard, a school teacher and record producer, when he repaired a car and sang at the same time. He is still doing both things. He has never been fond of glamorous nightlife or fancy clothes but prefer to live a simple life with his family and old friends.

His first record was on the Rex label, "Rock Pretty Baby,” which became a local hit in 1958-59. Next came Lottie Mo recorded for Valiant but leased to Joe Banashak in 1960. It was the record most played during Mardi Gras that year. (The carnival starts five days before Ash Wednesday at Easter and lasts for five days.) Everybody sang “Lottie Mo” when they danced through the streets, drinking and having fun.

Reynauld produced Lee's first two records, but then Lee left Reynauld. Lee was in New York and had not worked for 30 
days and was getting hungry. Although they had a lot of offers Reynauld didn't accept any because he thought they were paying too little.

But Lee wanted to sing and accepted an offer from the Apollo theater. Then Reynauld sued him for \$27,000. Lee instead went to Marshall Sehorn who was working for Bobby Robinsons FireFury Records, and recorded Ya Ya and Do-Re-Me - and the rest is history.

Fury was closed in 1965 and Marshall, who meanwhile had started his own label Sea-horn and lost some money, sold his car and paid a session with Lee that Allen Toussaint produced. Ride Your Pony started Lee’s second career.

Lee never sang gospel music, something he is very sorry for today. His mother was a great gospel singer. When she sang all work stopped in the neighbourhood where they lived. Everybody listened to her when she sang in the higher register. His father had left the family when Lee was very young and it was very difficult for his mother to provide for her three boys. Lee did his best to keep the family warm in winters through work and stealing coal from freight trains. Fats Domino belonged to a more affluent family, and now he had 12-13 children while Lee “only” had eight.

His best sellers so far were : "Ya Ya” (61), “Do-Re-Me” (61), "Ride Your Pony” (65), “Get Out Of My Life Woman” (66), "Working In The Coal Mine” (66), "Holy Cow” (66), "My Old Car” (67), “Confusion.” 
His new record was "Four Corners Part 1-2." The dance craze had lived a few months in the soul clubs and James Brown had made reference to it in one of his songs but this would be the first record to launch the dance. "Four Corners" was a pretty good song that perhaps should have sold better. During the chorus "North! South! East! West! the dancers faced these four cardinal points. Lee made a quick demonstration outside the office to the scrap warehouse and Marshall and Lee made plans for a major tour; in which at least one girl would be Lee's dancing partner on stage.

Lee Dorsey had the voice to become a truly great soul singer. Had he been given proper gospel training he could have given both Otis Redding and James Carr a match. Now he was a singer from New Orleans with a unique (but not really soulful voice). This trend had started with Louis Armstrong and continued with Professor Longhair and is heard today by Dr John. Fats Domino started as a R\&B singer imitating Roy Brown, but became a very relaxed vocalists with an immediately recognized voice later in the 1950s.

Although Lee lived so simply, he had two Cadillacs. "I always use my Cadillac to drive down to my junkyard otherwise people think you are penniless. But I prefer to drive a truck or Buick, actually,” Lee said, and fired off yet another blazing smile.

Then I was driven to the airport, and while waiting for the plane Marshall offered me a delicious gumbo a $\$ 3.50$ (the only hot meal I had eaten since Atlanta). In New Orleans, I had been speeding past all oyster bars and gourmet restaurants, and settled with bread and tins of beans in the hotel room. 
Marshall continued to tell me about his own experiences in the industry. While with Bobby Robinson he had also worked with Gladys Knight \& the Pips, Elmore James and Lightnin' Hopkins. In 1963 he quit Fury after a misunderstanding. But he continued to work with Lee Dorsey and got "Organ Grinders Swing” and "You're Breaking Me Up” leased to Constellation.

He started his own company - Sea-horn, and launched "Near To You” by Wilbert Harrison. They had met while working for Bobby Robinson. Marshall had also been involved with Danny White and Kiss Tomorrow Goodbye. In 1965 he began a close collaboration with Allen Toussaint and they signed a contract to lease the material to Amy Records in March 1965. In October the same year they started Sansu Records and in January in 1966 they moved into the current building. Now they had signed contracts with Neville brothers Art, Aaron and Cyril.

The records he was pushing at the moment were Art Neville's "Bo Diddley” and Lee Dorsey’s “Four Corners.”

Marshall also explained that the names of their record labels came from Gumbo French; Sansu meant 5 cents (san = cinq) and Deesu meant 10 cents (Dee =Dix) and Kansu meant 15 cents $($ Can $=$ quinze $)$ and su= cents.

Marshall said that I was always welcome to call him (524-3262) - collect.

Later I tried to digest all the impressions of New Orleans. This was truly a city with great musical talent. A lot of recordings took place here, just like in Memphis. But in Memphis, 
producers and songwriters tried to find good material and build sustainable careers while in New Orleans, the focus was on hits, trends, dance-crazes, covers and sequels.

Huey "Piano" Smith's own career was probably fairly typical for a New Orleans artist. There was much intrigue, professional jealousy and stab in the back in this city. What Huey Smith and Aaron Neville told me about the record business in New Orleans was not uncommon.

\section{Postscript}

In the 1980s, I was contacted by Joe Jones - of "You Talk Too Much” fame (1960). He was a New Orleans singer, band leader, promoter and general fixer then living in Los Angeles and he had taken over Roy Brown's business after his death. Without a doubt, Joe was the nastiest person in the record business I encountered. He really personified the worst of New Orleans and its record industry - the promises, the threats, paranoia, selfishness, the back stabbing and greed etc. That's probably the reason why New Orleans has not become America's musical capital despite all prerequisites there.

And also why I did not release that many R\&B reissues from New Orleans as I planned. It was difficult to get things done there. Meetings were cancelled or postponed. There were so many musical talents that nobody seemed to care, cherish and protect the artists.

I had asked everybody about Professor Longhair, but no one had been able to help me find him. (According to more recent data, 
he lived at 1552 or 1522 S. Rampart - or even remained at 1811 S. Rampart - his residential address in 1960?) Others said that he was homeless and swept the floor in a record shop and slept there.

In New York, a month later, I tried to find publicity material about him at the Atlantic office, but Bob Rolontz could not help me. Their archives were empty.

Although "Bo Diddley” was a flop, Art Neville later did well. The Neville Sounds was really the starting point for The Meters that came to Montreux with professor Longhair (June 30, 1973). But the concert was not very successful because the audience wanted to hear Longhair sing and play piano. The Meters accompaniment drowned much of this and the audience booed.

Professor Longhair sat for three hours behind the stage, waiting half asleep with the fur hat on his head, while the Meters rehearsed soul instrumental songs in the afternoon. He said that Atlantic had recorded enough material for four LPs with him. He had not met Fats Domino since the 1960s.

When I asked what songs he would play in the evening he said that he was tired of the old songs "I want to kill the old ones." But he did many of these anyway. He was anxious to play after having been waiting since two o'clock in the afternoon.

He started with an instrumental and then came:

"Looka No Hair "or "Baldhead," "Everyday I Have the Blues," "Dr. Professor Longhair Blues," (with the lyrics: "The boys call me Dr. Professor Longhair, The girls call me That Lovin’ Man”) “Tipitina,” 
"Paul Gayten’s “Hey Little Girl,” "Big Chief” (with a whistle), “Cry To Me” (Solomon Burke), "Hey Now Baby.”

By now, the audience had had enough of The Meters that drowned Professor's piano so they were resolutely run them away from the stage. Longhair continued alone with Ray Charles' "Mess Around," and finally a "gumbo" which was a mixture of different songs.

He was very tired now and almost fell off the chair when he wiped his eyes and brow.

Even if he wanted to play all night he was forced to quit. He limped out wearing his red suit, the fur hat and sunglasses.

When I asked Art what he thought about the audience's reaction to the Meters he said - just as (self-) critical as usual: "I heard in the very first song that everything was wrong. But they (the band) do not listen to me - they were in a panic. I will get a new group instead and record some older material.”

Art told me that he had met a great guitarist. The problem was that he had been in a mental hospital, and Art was not sure if he could handle the stresses of the music business. He said that he himself had often been near to be admitted to an institution too, considering how often he had been cheated, deceived and exploited. Although the Meters had had great success in the past five years, not much of that money had found its way to Art.

Art updated me about what had happened in New Orleans since last time: 
Earl King waved goodbye to the Meters at the airport. Meters and Earl had recorded an album but it was frozen due to contractual difficulties.

Chris Kenner had been released from prison. He had served some time in Angola State Prison where he had been since 1969.

Johnny Adams (soul singer) performed at The Hole In The Wall. (Or did he say that he was working in a similar small place?

Paul Gayten had produced Art for Chess when he was 17 years old - but the material was never released.

Al Scramuzza was back in the seafood industry after his efforts as a record producer.

The Meters had recorded with Betty Harris but it was never released. Now she worked (as an assistant) at a department store in Texas.

A sister of the Neville brothers family had been in the The Dixie Cups (of Chapel Of Love fame) - but before they became famous.

Art Neville now lived at 1115 Valence St, New Orleans. 


\section{Houston}

July $24-30,1968$

Wednesday, July 24

A gentle sleepiness in the subtropical heat hung over the large Texas city. The minibus from the airport had reached the town center. I could see by the surroundings and the people that we are on the right track. A man lies stretched out on the sidewalk and semi sleeping it off when we stop. Most of the other passengers have already disembarked outside the more prosperous hotel establishments. Lee Hotel at 1114 Polk Street is my new home for $\$ 14$ per week. I see the familiar cloud of dust when I throw the bag on the bed. The toilet has a door on the opposite side and when I curiously press the handle down I find myself in a different hotel room. On the bed is a rather battered white woman around 35 years old wearing a tight salmon-coloured dress. She has dirt blond hair and a rather sulky expression. I'm speechless. Is this woman worn and torn after working double shifts at the House of the Rising Sun in New Orleans? After a while she breaks the silence: "Can you buy me some food? I'm 
hungry,” she says in a broad southern dialect. I just shake my head and close the door. The porter had forgotten to mention that I shared the bathroom with another guest.

In the evening I strolled down to the city center. At Market Square (809 Congress) was the club Mother Blues where The Ink Spots were appearing (one of about three different groups using that name in the United States, said Evelyn Johnson later) - and Al "TNT" Braggs was due there in three weeks said a handwritten poster. While I was standing there a white man and a black woman around 25-30 years of age came by. They quarrelled and one could understand that they had been together for a while. This was very unusual in the Southern states.

I bought food and a 1/2-gallon bottle of port wine at a discount price. Perhaps with an ulterior motive if my roommate would knock on the door. I concluded the correction of my New Orleans notes.

Thursday, July 25

As soon as I woke up, I went to 2809 Erastus Street where the Duke-Peacock-Backbeat-Songbird Records was housed in a neat brick building. It looked like a well-built Swedish townhouse in one of Stockholm's better suburbs. I think the Bronze Peacock nightclub had been there before.

In a room sat Evelyn Johnson, Don Robey's right hand. Leaner Brothers in Chicago had recommended that I contact her. She had worked with Robey since the late 1940s and took also care of the Buffalo Booking Agency. They booked not only all of 
their own artists, but also many others like B. B. King in the South. Evelyn, who was also Bobby Bland's manager, was very light-skinned, and her hair was light blond. She informed me that Don Robey was away at a conference for southern independent record labels. Not many worked at Duke-Peacock. I saw only a couple apart from Evelyn, and all were black.

As we talked, Buddy Ace came by. He seemed to be in his early thirties and was quiet and a bit shy. He looked and moved like an athlete (A mix of Carl Lewis and Muhammad Ali). Buddy Ace was launched as the replacement for the tragically deceased Russian roulette player Johnny Ace (1929-54). A bit strange as Buddy was really a different kind of singer; he sang soul-blues - and not only ballads - and he did it very well. He came by to collect air tickets and schedule for the next tour. I think it was on the west coast.

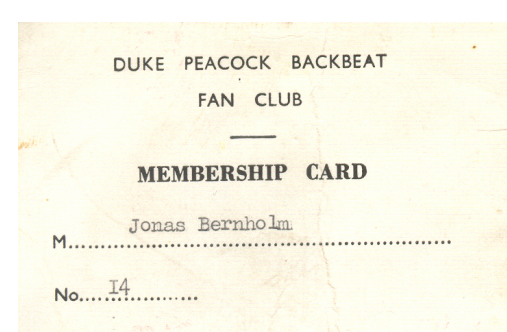

Duke Peacock Fan Club membership card
I was probably the only Swedish member of the Duke-Peacock-Backbeat fan club, and thus pretty well informed about their new artists. I had also promised to report in the fan club magazine "Soul To Inspect." Duke-Peacock always

launched many new artists but in the end they were dependent on the record sales of their older secure names Bobby Bland, Junior Parker, Joe Hinton, and O.V. Wright. Only rarely did they find new successful artists and had hits with them. 
Between the hits, Peacock's massive gospel catalogue carried them through. It was probably the largest in the United States and very important for the company, confirmed Evelyn.

Like many other independent labels such as Chess and Atlantic, they sent their artists to outside producers in Memphis or Muscle Shoals. Duke-Peacock didn't have and perhaps never had a distinctive sound like Tamla Motown, Stax, Hi or Allen Toussaint's Sansu records. Despite the fantastic gospel catalogue they were not able or willing to use it as a breeding ground for soul singers.

Texas didn't have the multitude of talented soul singers like for example Georgia. The gospel training in Georgia was probably better and there were probably more Gospel groups for youngsters to join. The Soul Stirrers from Texas seem to be an exception here.

Johnny Copeland and Young Jessie were Texans like Joe Tex and Al "TNT" Braggs, but these two soul singers were great performers first and singers next.

In the 1940s and 1950s, King and its subsidiaries Federal and DeLuxe had extensive catalogues in both R\&B and Country and Western. But the aging and half blind Syd Nathan was now totally dependent on one artist - James Brown. Don Robey was in a similar situation with Bobby Bland and O.V. Wright.

Evelyn was merciless toward some of the new artists they had launched. She said about Barbara Favorite, whose "Two Way Radio” had been slightly noticed in England: "She’s a big child 
who does not understand anything about how to behave, or build an artistic career." This explains why she only had one release on Backbeat. But Evelyn felt that the Lampsisters were good and promising.

Joe Hinton was in Boston and received treatment for a skin disease, she said. But it turned out to be much worse. Claude Jeter (formerly of Swan Silvertones) said at a gospel concert in a Harlem church on 116th Street a few weeks later that Joe, who earlier sang with the Spirit Of Memphis Quartet, was dead. It was obviously a serious form of skin cancer. Little Carl Carlton's “Competition Ain’t Nothing” (Duke 588) was a big hit that summer. "He don't look older than twelve, but he is actually sixteen years old,” said Evelyn. It was recorded in Detroit.

Evelyn showed me the recording studio, which was empty. "Not many recordings are made here today," she said. "Both O.V. Wright and Bobby Bland record in Memphis, and sell very well on LP.”

Ten years later, Evelyn added that she never understood why O.V., who looked like a Pentecostal preacher after the years with Gospel group Sunset Travelers (of Memphis), had broken down his health with hard drugs.

Evelyn was annoyed that Little Milton had built his entire career on imitating Bobby Bland, and not only on record. If Bobby sang a song and lifted one arm then Milton did a cover record and while on stage he lifted his arm at the same moment. But she calmed down when she heard that Bobby came in at sixth place 
before James Brown (No. 7) in Blues \& Soul's annual poll of the best soul singers.

The staff of a record company can be either of two extremes. At Stax Records in Memphis everybody seemed without exception to be music lovers who were not adverse to work on days off and listen to recordings at home. Evelyn Johnson seemed to be a motherly person who could handle artists and bohemians well. She created order out of chaos, but didn't take much part in the creative process.

She asked me to say hello to Tony Cummings, editor of soul and R\&B magazine Shout, and a friend who had been there the year before.

Then she called Bob Garner. He was working at the Palladium Ballroom, at 3145 Southmore, tonight. It was Don Robey's club, and the leading R\&B and Soul Club in Houston. She told Bob about my arrival, and she also promised me free discs.

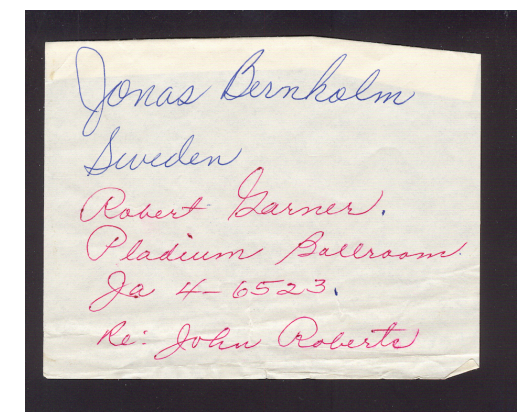

Evelyn Johnson introduction note

Other clubs she recommended were:

Cinder Club: (Dixie Drive 3200)

(Cafe) Casino Royale (Almeda 5500)

(I think Ray Barnett owned one or both of them.) She also 
recommended that I check the club sides in the Houston Post. They used to be detailed and precise.

Disc Jockey Skipper Lee gave me more addresses later.

I later understood that the black people in Houston had two different entertainment districts to choose from.

Dowling Street had blues clubs and juke-joints. Lightnin' Hopkins appeared here, and Peacock Records began here.

In the other district were the major soul clubs. It was about a 45-minute walk from my hotel, in the other direction. The big night clubs were like roadhouses with large parking lots. They attracted a motorized black and white soul audience. The wealthiest blacks in the South lived in Houston. Still, those big clubs were not that well attended during this summer.

I called Marshall Sehorn in New Orleans. He wanted me to make contact with the Crazy Cajun - Huey Meaux - an old pal of his "He has been in prison for a while, but he’s OK," said Marshall.

There was rain in the air when I walked to the Palladium Ballroom. Bob Garner let me in for free. This was Houston's biggest soul-club, with a fairly high stage at one end and a bar to the left. It had a big dance floor in front of the stage and tables at the sides and in the back of the room. Here some of the greatest soul artists and soul packages appeared during one-nighter tours in the South. The Paradise Club in Memphis was maybe two thirds in size.

Admission fees were charged because Houston was a "brown 
baggin"” town. Alcohol was not sold, only beer. If you were not happy with that you brought your own unopened bottle in a brown bag.

James Brown says in his autobiography that this club held 2500 people. (The Apollo Theater had "only” 1800 seats.)

At this time James Brown's minimum fee was approximately $\$ 7500$ per night. But he usually got a lot more. Even if the James Brown Revue mostly was booked in outdoor stadiums and auditoriums he could accept an odd gig on an off day if he took the income at the door (2500 people at $\$ 3=\$ 7500)$, while Don Robey took all the money on beer sales. (These are my own speculations. Don Robey did not tell me how he ran his ballroom-club.)

Before the John Roberts show Bob Garner, his manager, introduced me from the stage and I stood up and bowed. Bob then said that John Roberts was one of the ten most popular soul artists in Europe! (I let this exaggeration pass without protest because Bob also called me a well-known and leading music reporter, and gave me free beer.)

Still, John Roberts was probably the second hottest local rising star at the moment, after his success with “Sockin' 1-2-3-4.” The first must have been Archie Bell \& the Drells.

But $\$ 7500$ was not received at the door tonight. There were only around 150-200 people in the large hall. 


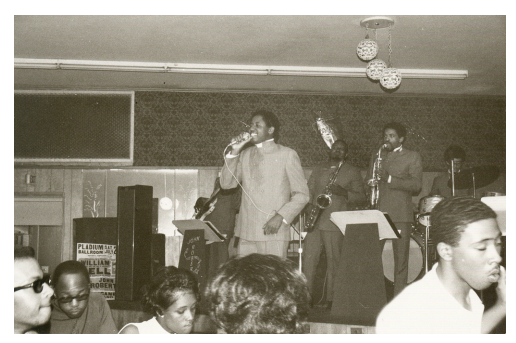

John Roberts at Palladium

Ballroom, Houston, with the Hurricanes

John was born in Houston in 1941. His mother was a gospel singer, and his father also sang solo in church. But John did not. He had started playing the trumpet at age six and when he was in church with his parents, he played solo. Two and a half years ago, when he was contracted to Duke, he took up singing seriously.

He was a bandleader in high school and wrote all the arrangements and songs for the school band and for his own six-piece band. But he'd rather play French horn than trumpet nowadays. "There is less competition on that instrument." He got his high school diploma in 1959 and at the University (1959-63), he studied classical music and French horn. He was a music teacher for a while, but the pay was so bad that he started a new band. He played the trumpet and sometimes sang a little "for fun." He was discovered in 1965 by Bob Garner, one of Don Robey's talent scouts, and got a contract with Duke Records.

His first record "Cold Hearted Woman" / "The Hurricane" did well locally. But his next, "Sockin’ 1-2-3-4" / "Sophisticated Funk,” was a real smash and a Top 30 success, said John. (It stayed four weeks on the Billboard Hot 100 with the highest position of no. 71 in December 1967.) Thereafter two records followed: "To Be My Girl” / "Something Reminds Me Of You," and "I'll Forget You" / "Be My Baby." All were released on 
Duke. He toured in Texas and neighbouring states and the band had been in Cleveland, Ohio and played on a disc-jockey meeting in Miami. I think he toured with Bobby Bland for a while too. John could be reached at the address 3145 Southmore (= the Palladium Ballroom).

John was a much more versatile artist than his 45s and especially “Sockin' 1-2-3-4" suggested. He felt most comfortable with slow songs and his vocal favourites were Marvin Gaye, Lou Rawls and Sammy Davis. He hoped to break into the bigger nightclubs where the money was.

His band was called the Hurricanes and their repertoire this evening and on Saturday two days later consisted of the following songs:

"Walk On By," "Dock Of The Bay,” "Nitty Gritty” (Horace Silver), "Since You've Been Gone”(Aretha Franklin), "Tell Mama”(Etta James), “Masquerade Is Over” (standard), “I Can’t Stay Away”(Impressions), “Lover’s Holiday,” "If I Had A Hammer," "Work Song," "My Girl,” "If I Could Build My World Around You” (M. Gaye \& T. Terrell), “Hangin ‘On,” “God Bless Our Love” (The Ballads), “Grazing In The Grass” (Hugh Masekela), “To Be My Girl” (Follow up to “Sockin' 1-2-3-4”), "I’ll Forget You” (His latest single), "Something Reminds MeOf You” (where he made space for a solo guitarist), "Kind Of Good."

"Sockin' 1-2-3-4" was the highlight of the show, and he was helped by a female dancer to illustrate the song.

John was a versatile musician with a rather sweet and soulful 
trumpet tone. The Hurricanes were competent and sounded pretty good. They played instrumentals but otherwise John sang and often had a trumpet solo in the middle. He was a laidback singer, and no screamer. The songs were often slow and they played mostly dance music for an audience that wanted to dance close together. Needed were more uptempo songs, more intensity and a more extroverted artist to really ignite the crowd. It was otherwise a pleasant evening where I had talked music and entertainment with two local beauties who also drove me back to the hotel.

Friday, July 26

Bob Garner had invited me to his office and I was on my way to 3325 Dixie Drive and the Bob Garner Enterprises. He was a bit distracted and not very talkative. I think his mind was occupied with his young and very attractive secretary who moved around him like a cuddly kitten. (She reminded me of Eartha Kitt....) I received a couple of records with John Roberts and some old pictures of James Brown. He had appeared at the Palladium lots of times and at Robey's older clubs too.

Bob phoned to Duke and talked to Evelyn and ordered the missing two 45s with John Roberts. Then he drove me to $\mathrm{KCOH}$ (5011 Almeda). This station had a studio that passing-by motorists could look straight into and communicate with the DJs by headlights and horns. The owner and program director was Swedish-descendant Donald Sundeen, but it was Skipper Lee I wanted to meet.

$\mathrm{KCOH}$ was a "sundown station" that started at sunrise and 
closed at 8:30 pm when the sun was down. At night there were very few listeners, because people watched TV. They had most listeners between six and nine in the morning and between four and seven at night when people drove home from work. It was cheaper to advertise at other times. The station only played soul music and was No. 3 out of 32 radio stations in Houston.

They had six DJs employed. The playlist contained 60 songs, of which five were instrumentals and between five and ten were new entries every week. They had a Top 44 chart plus one Pick of the Week which the music director usually chose. The DJs and the music director picked the new entries. But the program director had the last word.

They received 300 new singles in the mail every week. They played circa sixteen records every hour and had circa 18-20 minutes of commercials plus seven minutes of news and weather. They did not have any editorials where the station was expressing their own opinion. Twenty five percent of Houston's population was coloured and were the station's core audience, but many white students listened too. That group grew rapidly.

The station's most popular DJ was Skipper Lee (Frazier) and he was also the manager of Archie Bell \& the Drells that recently had topped the charts. He had met them at local talent shows three or four years ago. They could not get any other type of gigs, and always appeared in the same dark, very worn costumes. Eventually they had to use overcoats to cover holes in their pants. Then Skipper had to talk for hours and use all his powers of persuasion to persuade a local club owner to hire the group for $\$ 5$ per person. He finally said no, arguing that it 
was too expensive. But not long after “Tighten Up” hit, the club owner paid \$200 to every group member and grossed \$1400 per day and earned himself $\$ 1800$ for two days. Today, the group cost $\$ 2000$ per night and did the same show as always.

Skipper said that he had written the spoken intro - "Hey everybody, I'm Archie Bell and The Drells from Houston ... etc" and then Archie had improvised the rest. But Skipper did not like the song, and gave his composers’ rights to Billy Butler and lost a lot of money. Archie was in the military right now and had to stay there for ten months unless President Johnson intervened. The Drells continued to perform but without Archie. They were announced at the Regal Theater in Chicago but never entered that stage. We in the audience were never told why. But it was a bogus group and a surprised Skipper Lee, who was in Chicago, had stopped them. That false group had been performing all over USA.

“The Tighten Up” was a dance and now they followed up with another dance - "The Yankee.” It would be launched in the song “Jammin’ In Houston,” where the group also improvised part of the lyrics. Skipper thought it suited the group’s personality.

Archie was a competent hunter and he used to take an occasional newly shot squirrel to Skipper Lee Frazier's home at 4406 Reed Road in Houston. Skipper also recommended two churches that used to have good Gospel on Sundays: St. John Baptist Church at 2222 Grave with service and worship from 10:30 to 11:30, and the Missionary Baptist Church at 2708 Webster between 12:00 and 1:00 pm. 
I also talked with the station's newsman, and watched when the pretty receptionist recorded her lines for a commercial. $\mathrm{KCOH}$, as well as many other stations, made ads for local businesses in their own studio. With five fine soul LPs under my arm, that $\mathrm{KCOH}$ was not gonna play themselves, I left the station.

In the evening I went to the Cinder Club on Dixie Drive 3200. I had seen the name Upsetters on a poster and was excited to see Little Richard's old backing group. The Upsetters had been announced in New Orleans also and I thought they were out on tour. But it was the Americans of 68, a mediocre bunch, who in this fraudulent manner had renamed themselves. They backed a pale number of dancers and singers. A very drunk young black man, who I think was called Ricky Williams jumped around with a tambourine. He claimed that during the daytime he was an assistant to a heart surgeon. He must have been talking about legendary Houston surgeon Michael DeBakey, who of course would never let Ricky into his operation theater.

Earl Rader, advertised as "Mr. Blue Eyed Soul,” did not do any better than the dancing duo Tiger a Go Go, with a white girl and a black guy. She had a Swedish mother and they were married.

This was perhaps a controversial show that challenged racial boundaries, and it drew a lot of people. The audience was half white, but musically, it was one of the worst I'd seen in the USA. Who had recommended me to go there? Was it the nice girls I had met the night before?

Saturday, July 27 
I walked to 613 Preston and radio station KYOK, but the door was closed and I went instead to a grocery store and bought food. Then I rested before tonight's show with William Bell at the Palladium Ballroom.

Bob Garner let me in for free this evening too. Don Robey was back and Bob moved a little uneasily around the room. He was reduced from manager to doorman. Don sat by the cash counter wearing a cap with a green translucent celluloid screen. It was important to have an eagle-eye when dealing with money. One must not be blinded by the ceiling lights, whether you were a professional poker dealer - a man with a golden arm - or handed tonight's payments.

I did not know of Don Robey's reputation as one of the toughest record company executives in the United States. He was a phenomenon in the South. Even though he was coloured, but fair-skinned, he had managed to make his way in an all-white world and build up his own record label. At a time when racial discrimination was the same as in South Africa.

Little Richard was beaten up good by Don, who perhaps felt that Richard was too loud, vulgar and a transvestite. He always carried a gun, but he treated me in a very friendly and sympathetic way. He created a bond between us. He smiled friendly to me, and nodded encouragingly to the bar-girl who poured me another free beer, whenever my glass was empty.

Robey had started as a club owner and his Peacock clubs, Golden and Bronze, then gave name to Peacock Records. While Duke initially had been a Memphis label that he bought. (The 
Atlanta club, the Royal Peacock, was not included in Robey's empire.)

Ira Tucker of the Dixie Hummingbirds, who had a 20-year collaboration with Robey and Peacock Records, have testified that this was based on mutual respect and worked just fine. If Robey had not been honest, the Birds would have left soon. Ira was very sensitive if anyone tried to cheat him.

Robey was a man of strong principles, and Duke-Peacock Records were handled impeccably. His organization had a friendly, familial and solid atmosphere. The brick house stood strong and Evelyn Johnson was extremely professional. Sometimes Robey even carved his name in the 78-disc stampers - as a quality guarantee. Perhaps Robey preferred to work with gospel artists? They behaved better and were more family oriented. But the blind, alcoholic Archie Brownlee must have caused problems when he created some of the best gospel recordings of all time along with the Five Blind Boys of Mississippi.

While many record company executives used a lot of time and effort to persuade the gospel music artists to start singing pop and soul it seemed that Robey was satisfied with a gospel catalogue and status quo.

Robey was also known as his alter ego Deadric Malone who seemed to have composed almost all the songs. Robey bought the rights for a pittance and then added his own name. He was certainly a complex personality. But his long relationship with 
Bobby Bland, and to all gospel groups indicate that he certainly did a lot of things right.

The star tonight was William Bell. He was one of the Stax family's most prominent members, and a friendly cultured man and a true mother-in-law's dream. He traveled with an extraordinarily beautiful and cultured young woman. This couple would have been an adornment on the cover of one of the Johnson-press magazines (Ebony, Jet Magazine), where they showed off their very tasteful home.

He was born in Memphis July 16, 1939 and grew up on Saxton Street, just two blocks away from the current Stax studio, but moved (when he was 12? years old) to the north of Memphis. He sang gospel music in the Central Baptist Church Choir, but only rarely solo. William was also a student in the Booker T. Washington High School, which became a meeting place for aspiring artists in Memphis.

He was a good student and dreamed of becoming a doctor. But he started to sing $\mathrm{R} \& \mathrm{~B}$ and was soon a persevering participant at the Palace Theater's talent shows on Beale Street where Al Jackson Sr's band used to play behind the competitors. This was around 1953 when William was still in high school. The winner received $\$ 10$ and the second prize was $\$ 5$ and William walked away with first prize many times.

He became in demand in Memphis and worked for two years at The Plantation Inn on weekends. Then he came to the Flamingo on Beale Street, where he was backed by Phineas Newborn's big 
band (around 1955). Phineas taught William the basics of stage presence and presentation. And "how to be a star," said William.

He started a vocal group while at high school called the DelRios. They won the second prize, a recording session, at a talent show and recorded "Alone On A Rainy Night" / "Lizzie" for the local company Meteor (1956). William Bell wrote both songs and was accompanied by Rufus Thomas group the Bearcats.

William never mentioned the company name unaware that the record company's products a few years later would gain cult status. A copy of that record is probably today worth more than the payment he received this night at the Palladium. The record passed unnoticed, and the group disbanded after a while, but William had a taste for more, and began to sing solo.

When he was not working he frequented clubs on Beale Street such as Handy's, Flamingo, Hippodrome, Elks Club, Curry's, etc. This was a street that really swung in the early and mid-1950s. Here one could hear the three most popular Memphis orchestras - Bill Harvey's, Al Jackson Sr's and Phineas Newborn. Confidence grew after winning all the local talent shows and he continued to the Mid South Talent Contest, where contestants came from four nearby states. There, he won first prize (1958) and \$50. This was his first big break. He concentrated on sophisticated ballads and his favourite song was Danny Boy. He got more and more regular work in the larger clubs in Memphis. He got to know other local artists such as Carla Thomas, who, however, went to another school. Booker T. (without the MGs), Rufus Thomas who was established as a DJ, a M.C. and a dancer but not as a singer and others he 
remembered from that time in Memphis were jazz artists Hank Crawford, David Newman and Willie Mitchell and Bill Harvey, the band leader who arranged for B.B. King.

William used to listen to B. B. who was a DJ at the same station (WDIA) that Rufus Thomas later came to. B.B. used to advertise a vitamin tonic and on weekends he got fifteen minutes to sing and play himself.

In 1959 William moved to New York where he studied music and drama, and worked with a vocal coach. He played a little guitar and piano for household use. He decided to focus on the music and show business and put medicine on the shelf. After about a year in New York, he moved back to Memphis (1960) and got to know other future major players, in the circle around Stax Records, such as Steve Cropper.

In 1961 he wrote “You Don’t Miss Your Water.” Actually, he reworked a traditional song. He recorded it at Stax and called it his first record. It sold well enough in the Southern states to enter the Billboard Hot 100 in 1962. Today, it counts as a soul classic. “Everybody Loves A Winner” and “A Tribute To A King” were his other Hot 100 entries then.

William mentioned some of his more memorable recordings like “Any Other Way,” "I Told You So,” “Just As I Thought,” "What Can I Do To Forget," "Monkeying Around, "Who Will It Be Tomorrow,” “Crying All By Myself,” "Marchin’ Off To War.”

"Everyday Will Be Like A Holiday” was not intended to be a Christmas record but was now regularly broadcast on this 
holiday. His “A Tribute To A King,” which came out after Otis Redding's death, was originally a B-side. William described himself as a ballad singer but with "Never Like This Before," he also started to sing faster songs, such as his big hit "Eloise Hang On In There.”

Bookings poured in after "You Don’t Miss Your Water” and William toured until April 1963 when he was drafted. He was stationed in Hawaii, where he formed a five-piece band.

Officers were his main audience. They wanted to hear numbers from the musical South Pacific, but William still managed to sneak in an occasional soul song. He also continued his drama studies. His time in the military was not wasted.

In April 1965 he was discharged. Meanwhile Stax had continued to release records. They had enough recordings in the can for an album. But the audience had forgotten him and he had to start over again. Meanwhile, Otis Redding had taken over Williams’s position as the number one male artist at Stax. After a while his hits like "Never Like This Before" and Eloise charted higher in England than in the US.

In Memphis, Steve Cropper had said that Judy Clay, a new artist with a gospel background, had been paired with William Bell. His latest release was a duet with Judy Clay called "Private Number” / "Love-Eye-Tis” and it entered the Hot 100 on August 31, 1968 and stayed there for six weeks.

John Roberts and his Hurricanes warmed up the crowd of circa 
400 people, and then gave room for William who was a very good entertainer and singer.

His two sets contained fine versions of songs like:

“Knock OnWood” (EddieFloyd), "Yesterday," "Memphis Soul Stew" (King Curtis).

He sang three ballads which I guess had been in his repertoire since many years:

"For Your Precious Love” (Jerry Butler \& The Impressions), “Try Me” (James Brown), “These Arms Of Mine”(Otis Redding).

William's interpretations certainly did the originals justice. Then came:

“Soul Man,” "Everyday Will Be Like A Holiday," “Tribute To A King," "Every Man Ought To Have A Woman," “Ain’t Got No Girl," "You Don't Miss Your Water," "Never Like This Before,” “Everybody Loves A Winner,” “Eloise Hang On In There.”

He was not the kind of singer that brought his audience into ecstasy, but everybody went home in a happy mood. Despite his fairly big hits during 1967-68 he toured alone and picked up local accompanying bands on the road. His regular backing group was Johnny Jones \& The King Casuals. William produced "Purple Haze" with them. Jimi Hendrix had been a member of that group, earlier. (Hendrix's name was not mentioned by William.) William still played guitar for household use.

Popularity can have drawbacks, and he remembered a gig in 
Daytona Beach when a large woman, certainly weighing over $110 \mathrm{~kg}$, pushed her way to the stage and began to embrace him and lift him up in the air. But William, who weighed only about $60 \mathrm{~kg}$, continued to sing. "There was nothing else to do," he remarked.

When he listened to music he wanted to relax and preferred to listen to relaxed singers like Frank Sinatra and Sammy Davis Jr. Among soul colleagues his favourites were Otis Redding, Sam Cooke, Arthur Conley and Joe Simon. William seemed to have been born in a upper middle class situation. He was well behaved, well-mannered, and made a purposeful impression.

He later started his own record company in Atlanta named Peachtree Records. There he produced and recorded artists like Mitty Collier, Johnny Jones and the King Casuals and Emory and the Dynamics. In 1969 he enrolled at the American Academy of Dramatic Art in New York. He wanted to be an actor just like Carla Thomas, who underwent a similar training.

My interview with William had a comical after play. A few months later "William Bell" toured England. What he said in interviews had nothing in common with the William I had met. This impersonator had not studied William Bell's background. He was supposed to just look and sing like William. I had to reveal that the English soul-press had been tricked by a fraudster. My interview was published instead.

In England groups were then announced as "The Fantastic Supremes” or "The Great Temptations." But they had nothing in common except skin colour. Pictures on album covers were rare. 
Instead female (white) models were used and soul magazines were often text only. It was not easy to recognize even a popular soul artist. (I had seen one phony Drifters group in England in 1967. They were good though.)

The nightlife in Houston was similar to Memphis with early closing and a brown bag policy. The Palladium closed already at 1:00 am. It was far too early, I thought. I got a ride to the Casino Royale (Almeda 5500) with a bunch of night owls, who also wanted to continue partying. I felt in a good mood after all the free beer, so I rushed in, but this club was also closing. Suddenly I found myself in the office where two men sat and counted cash. I was not at all welcomed there ...

Sunday, July 28

After much needed sleep, I corrected my notes. Sunday dinner was a big can of pork and beans and a loaf of bread. It was affordable despite my rapidly decreasing travel funds. Still it was edible, unlike the small carton of eggs I had bought, hoping to find a cooking plate at the hotel. They had to be eaten raw ...

The evening was reserved for the Al “TNT” Braggs show. It was advertised at the Delta Club (4302 Reed Rd) between the hours of 9:00 pm and 1:00 am. But the Delta Club had burned, and the show had moved to Cinder Club, which was nearby. Thankfully, I was there in good time and could read the handwritten note outside the Delta Club.

Those who are inclined to see conspiracies might find a connection between this fire and Jack Ruby's strip club in 
Dallas. It was in such poor condition that it was raining in. Ruby shot Kennedy assassin Oswald. Was the fire an insurance fraud or a settlement in the criminal underworld? The guys who counted the cash at the Casino Royale yesterday didn't seem like bank clerks to me. Anyway, the rumour was that the fire at the Delta Club was arson.

I managed to get in free at the Cinder Club and was ushered into Al "TNT" Braggs dressing room. There he sat and flirted a little with Mary Jackson, one of the female singers. He had a do-rag on his head to keep his hair in the right volume and shape.

The African-American barbers then created hairstyles of rare beauty. Mahalia Jackson worked in her own salon, even after she had become a well-known gospel artist. Maybe hair sculpture was as important as singing to her?

I've always had a weakness for artists who used colourful nicknames. Al “TNT” Braggs lived at 2800 Route St, Dallas, Texas, and he was booked and managed by Show Co. Inc. c/o Jack Calmes and Angus Wayne III.

Al was a young man deserving his nickname just as much as Mr. Dynamite - James Brown. He was actually one of the most dynamic black entertainers I have ever had the honour to see.

In 1955, he met Jackie Wilson, who taught him the basics of artistic presentation and his training was perfected with a dance lesson by James Brown. I don’t think they felt that Al was a poor achiever.

He was a nice acquaintance; certainly not ostentatious but 
almost humble. I had already bought "Earthquake,” the only single released with him in England (at the Vocalion label). In the soul magazine Home of the Blues, Robert Sye, whose name I have not seen later, wrote a short presentation of TNT. I had also seen Al's face on the flyer issued by Phil Walden's soul artist agency in Macon.

Al Braggs was born in Dallas, Texas on May 23rd in 1938 and brought up in a pure gospel environment. His father was a preacher and his mother used to sing spirituals home. When he was old enough to open his mouth, he would sing behind his mother's solo singing. She taught him the basics of singing gospel. Then he sang solo in Salem Baptist Church Choir and around 1950 he formed his first group, The Spiritual Stirrers. "Gospel was the only music I heard so it was natural for me to form a gospel group,” said Al. But in 1952, he became interested in $\mathrm{R} \& \mathrm{~B}$, and started a group called the Five Notes. He was inspired by other vocal groups and they tried to sing like the Orioles, The Flamingos and The Moonglows. They sang locally while still in school and were discovered in 1955 by Dallas DJ Chuck Donaway, who took them to Chess Records. They recorded "Park Your Love" / "Show Me The Way" as the Five Notes. It sold decently and they became sought after outside Texas and went on a five-month marathon tour that took them all the way north to Milwaukee and Wisconsin before returning home in 1957. Then they changed their name to the Five Stars and recorded "Polly Molly" / "Forever and a Day" for the Dallas Jan label. Al sang lead. (These songs were (also) released under the name the Five Masks.) 
They sold decently, and they were engaged in the film Rock Baby, Rock It (1957) along with other stars such as Johnny Carroll, Roscoe Gordon and the Red Tops. Roscoe performed his big hit from Flip Records - "The Chicken” - with a live hen on his piano - and the Five Stars sang the song "Free Bar" - Al said. (The film features the Five Stars singing “Juanita, Your Love Is All I Need” and "Polly Molly.”)

The film was shot in Dallas and now has a cult following as other films with great music but a reputation of being "the worst movie ever made.”

Then they changed their name (back) to The Five Masks. But now the members had grown older, some had married and they wanted money for their efforts and was not content to be idols for their school mates.

The group broke up. Its guitarist Carl Valentine and Al started their own four-piece band instead - the Carl Valentine Band where Al played the organ. (Al played several other instruments like piano, guitar, bass, drums and harmonica.) They were together for a year and often worked six days a week and eight hours per night. Then Al formed his own four-piece band where he sang solo.

Al had become popular in Dallas. His specialty was artist imitations and all the great $R \& B$ artists on tour used to come to the club where he appeared after their own shows. Little Willie John, Sam Cooke, Bobby Bland and others were all were flattered to see themselves imitated on stage. 
Don Robey discovered him in Dallas around 1960, and he got a contract with Peacock Records. This was followed by a steady stream of singles (about one or two per year), which sold OK. His more famous songs were "Cigarettes and Coffee," "Earthquake” and "That's All Part Of Lovin' You” and the 45 released afterwards called "I Like What You Do To Me.”

Bobby Bland and Junior Parker were Duke-Peacock's bestselling artists and toured together as the Blues Consolidated. But Buffalo Booking Agency understood that it was unnecessary to pair two such popular artists. They could earn more on their own and Buffalo decided to separate the dynamic duo. Joe Hinton became opening act for Junior Parker and Al Braggs opened for Bobby Bland. This was in 1961, and Al was with Bobby until he left in December 1965. Al started on his own in January 1966 and soon discovered that he made more money than when he worked with Bobby. After six months he could afford a horn section and then gradually expanded his band with more instruments, singers and Go-go girls.

In July 1968 the Al “TNT" Braggs Revue became Al "TNT" Braggs (vocals). (He no longer played the organ on stage as there was no room to transport it.) His younger brother Floyd Braggs (22 years old and born in 1946) also sang and sometimes Al \& Floyd worked together as a Sam \& Dave inspired duo. Band leader was then 25-year-old guitarist James Braggs (born 1943). Two singers were included in the squad - Rhetta Kelly and Mary Jackson. Behind them was an eight-man soul band consisting of guitar, bass, drums and a horn section with three saxes and 
two trumpets. The two Go-go girls Gladys and Tina also played prominent roles.

Al wrote his own songs and had also composed for Bobby Bland (“Call On Me,” “Save Your Love For Me,” and “I’m Gonna Cry”). He had written two songs for Sam Cooke: "London Bridge Is Fallin' Down” and another that he had forgotten the title of, but which was recorded shortly before Sam was murdered. Al got $\$ 800$ and the money made it possible for him to buy a home.

He was married and had two children, Danny and Terry and his wife also wrote songs (Perhaps he meant that sometimes, for tax reasons, he put his wife's name on songs.) Al designed the costumes for the show and made the band's arrangements and his last two records, including That's All Part Of Loving You, which became his biggest hit to date, had been arranged by him. His favourite arranger and inspiration was Joe Scott, the man behind all the classic hits of Bobby Bland.

(Later, I bought many of Al's 45s on Peacock. Several were good - but Al was primarily a live performer.) Al thought that he had a rather dull life. Is was all work and no play.

His own favourites was Otis Redding, Bobby Bland, Wilson Pickett, the Four Tops, Temptations, and he also admired Tom Jones. Right now, he appeared mostly in the southern states, but his popularity had begun to spread, and he would go to California soon.

Showtime! 
James Braggs Orchestra began the evening with a couple of soul instrumentals before Mary Jackson, who was a very handsome young woman, entered the stage with a Supremes medley and Dr. Feelgood and Hookie Dookie.

Floyd Braggs was next, and he did pretty good, but not remarkable, versions of

“I Ain’t Particular?” (It must have been Marvin Gaye’s Ain’t That Peculiar), “La La Means I Love You” (Delfonics), "Funky Street” (Wilson P.), “Midnight Mover”(Wilson Pickett),

Rhetta Kelly sang:

“ITake What IWant,” "Piece Of My Heart,” "Misty.”

She was a better singer than Mary but not as pretty.

Now the orchestra made itself and the audience ready and pumped out one soul riff after another. One of the Bragg brothers announced Al "TNT" using a similar introduction that James Brown did in 1962 at his Apollo album. Then the lights were dimmed. 
Al had said that the beginning was always the same: The stage was dark and suddenly you see a cigarette glow and when the headlights are lit again, $\mathrm{Al}$ is standing at center stage with a burning cigarette in his mouth. Slowly, he turns the cigarette out with one foot and then starts dancing around the microphone.

Perhaps as tributes to his dance teachers Jackie Wilson and James Brown, he bent

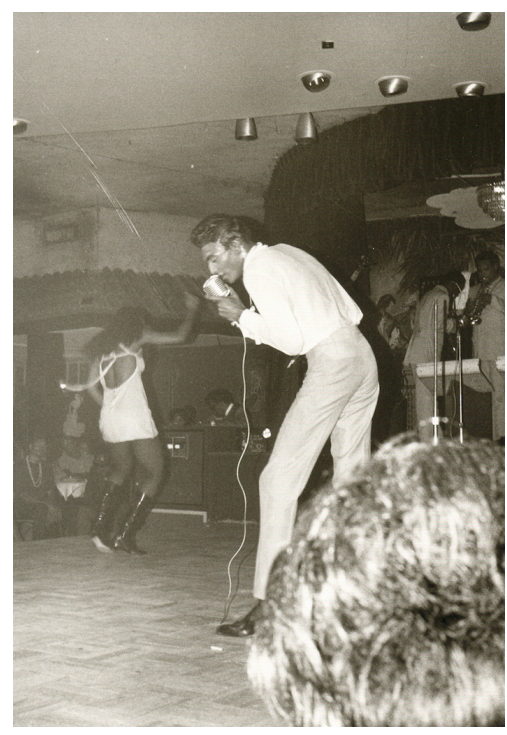

$\mathrm{Al}$ “TNT” Braggs Revue at Cinder Club down backwards like Jackie Wilson “Doin' the Limbo” (It was probably called something else when Jackie did it in the 1950s.) Then he did the splits and glided across the stage on one leg and did the "Mashed Potatoes" like James Brown.

Tonight Al performed:

“Don’t Fight It,” “Funky Broadway,” “Amen,”“Earthquake,” “That's All Part Of Lovin 'You,” "Happy Song.”

At a furious pace he danced and started singing his own and others' songs. He did not stand still for a second. His skinny body flew like a dry skin over the stage. James Brown's dance steps were demonstrated with verve as is the "Baby Workout" of Jackie Wilson. All at a breathless pace without the band or 
he missed a beat. This was the highest possible level of a soul performance!

But in the middle of the show, and after these six songs $\mathrm{Al}$ suddenly disappears. He must have fallen down from the stage and disappeared when the lights were put out for a moment. What had happened? The Go-go girls took over. They worked just as hard as Al. Their mini-skirts were wet with perspiration. Was this the end of the show? It was great while it lasted, but a bit short ... But within a minute, Al was back. He had just changed clothes! Now he put in an even higher gear and drove possibly even faster in this second set.

First he invited his brother Floyd and together they did a Sam \& Dave inspired set with:

“I Can’t Help Myself” (4 Tops), "You Don’t Know Like I Know” (S\&D), "You GotMeHumming” (S\&D).

There were several more songs during this evening, but I was now so absorbed by the performance that I stopped taking notes. That's a high compliment. It is rare to see an equally talented performer who has perfect control and the crowd in his hand. I did not want to miss a second of it. It is a very great experience to see an artist who gives everything and more on stage. After a while Al calmed down a little and invited a young singer from the audience. (He sang the other night at the Cinder club. I think his name was “Little Al.”) He and TNT sang a duet together. But then it was full speed again and at the end $\mathrm{Al}$ was laying on the floor with a microphone in one hand primal-screaming his 
heart out surrounded by the entire orchestra which had left the orchestra podium.

I was sitting at the edge of the stage, and when I took a step up over the edge to congratulate $\mathrm{Al}$ to this amazing performance, I felt that the floor was wet. This was amazing. I had heard that James Brown could lose up to 10 liters during a performance. He sweated through the soles of his shoes, it was said. He was so exhausted that he needed oxygen afterwards.

This had been a 10-liter night. (Al had been helped by Gladys and Tina.) Al's beautiful conk hairdo was hanging down in front of his eyes.

The club was packed, despite the scarce advertising. This had been an unforgettable evening, probably just like when James Brown or Ike and Tina Turner went back and forth on the Chitlin Circuit eight or ten years ago.

They also had singers and dancers and a great band and fancy costumes. The audience knew that these artists always gave everything. Al Braggs, James Brown and Ike Turner were not only artists but also band leaders, organizers, promoters and entrepreneurs. A successful evening was guaranteed and they always got re-engaged or extended engagements. Slowly but surely, they worked their way to the top. A hit was necessary, but if they could not give the audience what they expected they were not asked back.

Al was a Dallas artist performing in Texas and neighbouring states, but had not yet been seen nationally. James and Ike were 
musical geniuses who made it to the national and international top, while $\mathrm{Al}$ continued to work regionally. I had seen many soul shows in recent weeks. But this was the best so far.

My thoughts went to the Scott Brothers in Chicago, who perhaps with a lot of hard work could leave the local scene and get out on tour and become regional greats such as TNT. The only weakness was Al's voice. It was not powerful enough. He easily became hoarse. Despite all gospel music training, he didn't have the vocal strength of a James Brown or Wilson Pickett. But he had everything else and more.

Praise must go to Bobby Bland who dared to have such a colourful artist to open up his shows. He must have been very generous and self confident. (Please read the book Urban Blues, where Charles Keil describes his meeting with Braggs and Bland.)

Al set had taken almost two hours and the other artists had an hour at their disposal. It was a great evening with no dead spots. Nor had Al tried to "charm” his audience with silly phrases like "Let me hear you say yes!”

I managed to stay in a good mood on my walk home despite the fact that a car with a rather aggressive young black man tried to convince me to end the evening in his bed...

I guess Evelyn had called $\mathrm{Al}$ and said that I was going to be there. He was prepared to meet me and to give me a show I had never seen before. And he succeeded ...

Monday, July 29 
I went to the radio station KYOK at 613 Preston Ave and talked with Dick Oppenheimer who was the boss and Rick Roberts, its program director. They played music 24 hours per day and 12 hours of gospel music, including worship services on Sundays. They had 50 records on the chart and 65 records on the playing list (50 plus 10 extra songs and 5 instrumentals) including a “Station Pick.” The station's most famous DJs were Wild Child, and Billy Williams.

Circa 200 new records arrived every week in the mail. From those all seven DJs and the program- and music-director selected 8-10 new records. And a DJ could choose his favourites from the playlist and did not have to stick to a predetermined list. The station had editorials where their views on racial issues and social problems and poverty were presented. Houston had the nation's ninth largest and the Confederate's most affluent black population.

They were trying to inform and educate and not to propagate. They calculated that $20 \%$ of their listeners were white. Or as Dick Oppenheimer said, "I do not think George Wallace listens." He described the white population as quite liberal, but that very few black businesses advertised on the radio.

Dick, who was white, compared soul with psychedelic music and $\mathrm{C} \& \mathrm{~W}$. They were all different trends and the stations that followed other trends had also attracted a lot of new listeners among those that listened to for example Jimi Hendrix.

His own favourites were artists such as O. C. Smith, Lou Rawls, Bill Cosby, Tom Jones and Tony Bennett. But black entertainers 
had difficulty getting a job at the best nightclubs, said Dick. One exception was Billy Daniels (65 years old), his own favourite and whom he called the greatest black entertainer at the time. His biggest hit was That Old Black Magic, and he worked at fine nightclubs across the United States.

The atmosphere in these small southern state radio stations was often informal. In principle, one could walk in off the street and start a conversation with a DJ who was in direct broadcasting. The conversation was interrupted only when the DJ announced the next song or wanted to shout something in the middle of the record. I was never stopped by guards and locked doors and the DJs never showed that they felt disturbed.

Sometimes the DJ was visited by a girlfriend in the studio or holding a conversation on the phone with friends. Jingles and station-identification were on big pre-recorded cassettes that were fed in when needed. I found that they often took their important work quite easy.

They had a key role in the music business. Some took it a step further and made their own records or were managers for artists they launched. There were other stations where listeners could call in and talk. Sometimes they were badly treated by the program host when they wanted to talk about homosexuality or when they presented themselves as researchers of the UFO phenomenon. It was a type of program that had not come to Sweden yet.

My notes about what was heard on the radio in Houston were 
short and sketchy. Here are some songs I had not heard elsewhere. $(*)=$ Favourites:

(*) Bobby Bland - "Highway of Broken Hearted," (*) Jackie Wilson - "No Pity In The Naked City,” LaVern Baker - "I Cried a Tear,” Johnny Jones \& The King Casuals - instrumental, Chilites - "My Baby," (*) Roosevelt Grier - "People Make The World,” J.J. Jackson - “Too Late.”

Tuesday, July 30

My visit in Houston had been successful. People were generally friendly, and there was a relaxed, laid-back atmosphere. There had been very long walks but it was OK. The clubs were also more integrated here than elsewhere, and $10 \%$ of the guests were white. It was easy to get there by car and the clubs surrounding area, including the parking lots, seemed secure. But I had not come across any large and lively local scene and a lot of talent just waiting to break through.

I had no more contact with my roommate next door. I only saw her drag herself down once to the hotel's modest lobby and buy a coke in the vending machine. A rather stupid way to quench hunger and thirst, I thought, while drinking port wine myself...

I never had time to visit the United Rec. Dist., 1613 St. Emanuel, or Gold Star Recording Corp., 5628 Brock. I did not know where I got hold of the address of Zebra Records, 3326 Proswimmer (Artist: Henry Hayes)

The greatest experience here was the Al “TNT” Braggs concert. 
I assumed that there was an Al Braggs in each state. He had released records that sold decently and his stage show was absolutely top class.

The nice Scott Brothers and their orchestra in Chicago worked locally and would continue to do so if they did not make a $110 \%$ effort. That's what it took for James Brown or Ike \& Tina Turner to break through.

Even James Brown - "The hardest working man in show business" - had for some years been doing the same type of shows, singing other artists' songs, like TNT did right now. It required workaholics like TNT, Ike Turner and James Brown to succeed. No detail was too insignificant.

TNT's Go-go dancers had worked incredibly hard, and made the Go-go-dancing into a fine art, while the Scott Brothers dancers, called the two Ts, were more dazed and almost indolent.

Al TNT's performance was a brilliant example of how high the black entertainment and performing arts could reach. It showed how enormously generous these kinds of artists were. They simply gave everything and managed under simple conditions to give the audience maximum value.

Al had an eight-piece band with three solo singers and two Gogo dancers all dressed in stylish clothes. There was probably not much money left (for himself) after paying all expenses.

This concert finally healed the wounds I got 10 years back when I went to see my great Swedish idol at the time - Owe Törnqvist. He is considered to be the foremost Swedish 1950s rock artist. It 
was actually the first concert I went to of my own. Owe traveled alone without a backing band and only an acoustic guitar as backing and visited maybe four or five places in one day.

Stickan Andersson ABBA's manager coined the phrase; - "The audience is not stupid - it's more stupid!” He became a multimillionaire. Had he been working in Houston, Don Robey would have beaten him up and sent him back to his teaching job. The audience at the Apollo would have booed Owe out from the stage within seconds. But in Sweden he earned so much that he could retire already at age thirty. It took many years before the Swedish rock and pop artists began to treat their audiences with respect.

It was a mistake not to talk to Don Robey, just like I missed talking to Henry Stone in Miami. I never insisted to do a long interview with Jim Stewart (Stax). Marshall Sehorn and I had had a couple of good conversations in New Orleans but Allen Toussaint was difficult to get any information from. Perhaps it was only when I met Bobby Robinson (Fire/Fury) in Harlem a month later that I realized how important these independent producers were.

I kept in touch with Evelyn Johnson. I tracked Amos Milburn to Houston. She helped me with the contact and even managed to get some nice pictures with him. I let Evelyn Johnson have the last word when she 10 years later (1978) noted that "Al TNT" was very talented but his weak side was that he wanted to do everything himself. She probably meant that he had come further with the full support of the Buffalo Booking Agency. 
Al had all the prerequisites for a long career as he, like Bobby Rush or Clifton Chenier, never left his audiences disappointed.

Robert Sye had been right: “Anyone who has ever seen $\mathrm{Al}$ 'TNT' Braggs never forgets him!” But maybe Al made the same mistake as Amos Milburn when he included cigarettes not only in his stage show, but also private. (Amos stumbling block private was of course the Bad Bad Whiskey. Al got throat cancer and died in 2003).

Soul artists had a handicap. A normal voice lasted only a few years with the enormous strain subjected it to. Gospel singers were aware of this and many quartets had two lead singers that could switch. Otherwise, the solo singer quickly worn out their voice.

Evelyn Johnson Buffalo Booking Agency was in decline in 1968. They had lost several major artists. B.B. King was booked by Associated Booking in New York as well as Bobby Bland, though Evelyn was still Bobby's manager. She only had Roy “Treat Her Right” Head and the dying Joe Hinton. Maybe she was being ousted by Fats Washington, P. O. Box 26126 Dallas, Texas?

Duke-Peacock was sold a few years later to ABC just before Don Robey's death. It was only Bobby Bland's recordings ABC wanted. According to Evelyn most of Duke's vinyl records ended at the junkyard. 


\section{Los Angeles}

July 30 - August 8, 1968

Los Angeles was a shocker. The city was already very large and spread out, and to get around by bus and foot was very difficult. But travel funds didn't allow otherwise. I did not know that the music industry had two centers. There were many national record labels and big clubs in Hollywood. While the local music scene was in Watts and the center of Los Angeles. It was far between these places. To cover everything in just ten days proved to be impossible.

Tuesday, July 30

I settled in at a hotel near downtown Los Angeles. It was either located on Central Avenue, the legendary entertainment street, or on a side street to it. My room neighbours were an older couple. They had traveled around the world and were now writing a book about it. Unfortunately they had collected animal skins and hides on the way, which hung on clotheslines in their room. These poorly tanned skins smelled copiously of urine. 
Especially when their door stood open. It was like living in a urinal.

In the evening I called the desk of Soul Magazine and had a very sleepy response - perhaps by a lady who had fallen asleep on the job. Later a fire nearby kept me awake for a while.

Wednesday, July 31

I took the bus to Hollywood. On my way, I passed the town library. It was being torn down and rebuilt in another location to make room for a large car park.

First stop was Soul Publications at Suite 208, 8271 Melrose Ave in Hollywood. It was a fairly new house in pleasant surroundings with many trees. There were the chief editor Ken Jones and Regina Jones (I think both were black and married to each other) and especially Rochelle Reed, a white woman of my own age, who had recently been touring with James Brown and had written about it. It was a good article published in Soul Illustrated. I found the magazine on the aircraft. That's why I was there. James Brown was my favourite topic but I had since long worn out any listeners at home.

Soul Publications published Soul Magazine in evening newspaper format and Soul Illustrated in a magazine format. They were three or four writers including the Jones couple plus a secretary/switchboard operator. This was not a European fanzine run by enthusiasts, but people who hopefully were paid for their work. RnB World was a rival newspaper published in New York. The Los Angeles based black newspaper The Sentinel also wrote 
about entertainment. I remember a headline which reported Etta James' current problems.

The English and European soul and blues magazines, however, had higher goals in research and presentation of facts.

Soul Publications had devoted a number to Ike \& Tina Turner. I was hoping that Rochelle could introduce me to the couple and give me their phone number. It was not necessary, she said. Tomorrow they would inaugurate a soul club in Hollywood.

Rochelle suggested that I reported from Europe whenever we had a visit of a well-known soul artist. I later sent them a report from the Joe Tex tour in 1969. I don’t think it was published. When we parted Rochelle and the black secretary asked me about my astrological sign. I did not know - no one had ever asked this before.

I don't think Soul Publications was primarily aimed to a black audience. The Afro-American press wrote enough about their sports and show business stars in both the local newspapers and magazines (Ebony, Jet and Tan).

However, there was a fairly large white audience. They did not go to the black clubs but saw their favourites at large package shows or on TV.

Evelyn Johnson had added names on the list with useful and relevant contacts that George and Ernie Leaner had given me in Chicago.

Next stop was radio station XERB (8228 W. Sunset Blvd). I 
wanted to meet her good friend the DJ Buddy Lowe. He was also involved in Crest Records, which was located at 9109 Sunset Blvd. Buddy talked about what was going on in Los Angeles and he introduced me to a group of five or six men sitting talking in a room. There was George Grant, who had the artistic agency Apollo Artists Corporation at 247 Manchester Ave. He gave me his card and wrote down names and phone numbers on the back: Olympics (Walter Ward), Shirelles, the Penguins (Cleve Duncan), Platters, Bobby Day, Z.Z. Hill, Bo Diddley, Lowell Fulson, Coasters, Ray Agee, T-Bone Walker, Eugene Church.

These artists had their heyday five to ten years ago and then left the bestseller lists. Without yet making a comeback in the “oldies-but-goodies” circuit.

I tried to contact Lowell Fulson. He was in Los Angeles and recorded an album. His Tramp on Kent Records had recently sold well. Also on Kent was Z.Z. Hill - a fine soul singer. But he was not in the league of Jimmy Holiday, Bobby Womack or Ike \& Tina Turner (all on Minit Records).

I did not know that Los Angeles had a very lively vocal group scene where the Penguins were just the tip of a very large iceberg. In Europe we had basically only heard the Platters.

George gave me a disc with Ray Agee - Mr. Clean (Highland Records), a good Bobby Bland inspired recording that he was pushing. Fifteen years later, I corresponded with Ray. He replied and addressed his letters to Mr Burnham ...

Other local performers mentioned was Fred Hughes who had 
the current hit single, “Send My Baby Back.” Tomorrow night George was going to the California Club West at 8265 Santa Monica to see Ike \& Tina.

I shook hands with Al Scott, a rather corpulent man, who worked on Money Records (1065 E. Vernon), a former John Dolphin company like Cash Records. Best remembered then for Bettye Swann and her Make Me Yours. (John Dolphin, himself black, symbolizes the greedy record label owner stealing songwriting royalties from the composers. He was shot dead in February 1958 by the composer Percy Ivy in a dispute about money ...)

My list of interesting clubs had expanded with

\section{Club La Duce}

Coconut Groove (400 Wilshire)

Cotton Club

Mardi Gras

Memory Lane

Pied Piper

Red Velvet (6507 Sunset)

Whiskey a Go Go, 8901 Sunset, where Johnny Rivers was the big attraction. There was also a club in Watts called the "Club House” (90th/Western).

XERB was number two among the city's R\&B stations and played music 24 hours a day interrupted by 20 minutes per hour of commercials and jingles. The playlist contained 45 songs including six newcomers every week. Four "Picks of the Week" were pushed, and one song was played extra frequently. Music 
and Program Director chose the music. They had no news but sometimes an editorial about social problems facing the black population. Circa $60 \%$ of the audience was black and $40 \%$ were white, and the age group of 18-25 years were the most loyal listeners.

The station had nine DJs including Buddy Lowe. The most famous were Wolfman Jack and Magnificent Montague. The station XERB had previously gained notoriety when the Magnificent Montague, during the Watts riots, shouted Burn Baby Burn! (See the book with the same title written by Jerry Cohen \& William Murphy).

He said it so often and loudly, that many thought he was instigating the listeners. (Perhaps that's why they stopped the news broadcasts.)

This summer, the station and many others had a short prerecorded message by James Brown, which said, “Don’t burn, learn!!”

Montague was still working on station, but I did not meet him or Wolfman Jack. I knew the Wolfman as a singer on a couple of Howling Wolf/Screamin’ Jay Hawkins inspired singles (incl. "Strange") on Okeh, produced by Larry Williams. Later Wolfman Jack became a living legend as the DJ in the movie “American Graffiti.”

The other leading Soul Station was KGFG, at 4550 Melrose and owned by “Arnil Sharr.” I never had time to visit. According to Billboard, this was the number one R\&B station in Los Angeles. 
Next stop was Venture Records (8350 Wilshire Blvd). Rochelle Reed had recommended a visit to this newly established record company. A friendly girl in the reception escorted me into the recording studio where the Ballads were busy. They recorded an album and a follow up to their big hit God Bless Our Love. The LP was due for release in late August 1968 and they also had a big tour planned. A small, thin man introduced himself as Bob Relf. He was the producer.

A few years earlier the duo, Bob \& Earl's amazing recording Harlem Shuffle (1963) had been acclaimed in England when Beatle George Harrison called it his favourite record that year (1964).

In Europe speculations ran high who hid behind the names of Bob \& Earl. Some must have reached Bob Relf who seemed anxious to sort things out once and for all:

Bob Relf (born in Los Angeles); his real name was Robert Nelson Relf and he was "Bob.” Earl Cosby = "Earl” Nelson (also called = Jackie "The Duck" Lee). I still do believe that I was the first one in Europe to finally solve this riddle - with the help of Bob Relf, of course.

Suddenly, two men burst into the studio. They were sales and promotion-man Warren Lanier(e) and Mickey Stevenson, who owned the company. Mickey had played an important role in Detroit during Motown's early years and his name as a producer and songwriter is on many fine hits, for example, with The Miracles. Maybe he inspired Holland-Dozier-Holland to write Mickey's Monkey for the group. But he had recently left 
Motown's West Coast office and started on his own. His wife, Kim Weston, who had had some Hot 100 hits on Gordy as a solo artist, had followed him.

They were obviously concerned that their employees, uncensored, talked with me. But they soon calmed down and welcomed me to the business, which was quite extensive. I remember the office and studio-house almost as big as Stax in Memphis. There were as many people here, that I saw at Tone Distributors in Miami. Duke-Peacock had a small house in Houston and a lot less people and Sansu in New Orleans played in a considerably lower division.

During a break I had the opportunity to interview the Ballads' four members. Their God Bless Our Love was then at the 65th place on the Billboard Hot 100 list.

Nathan Robertson (28 years) sang the tenor part. Jon Jon Foster (24 years) was good looking and had a beard. Rico Thompson (26 years) was the group's talkative member.

Lesley La Palma (24 years old and baritone) sang lead on "God Bless Our Love” and on most tracks on the LP, while Rico sang lead on the B-side and on some LP tracks. The other members sometimes also took over the solo microphone.

All came from the Oakland ghetto where they began to sing outdoors below the street lights at street corners. But they never sang gospel in church. It was very rare that the soul singers I met that summer lacked that experience. Or maybe they wanted to be identified with the Black Panthers that had been formed and had 
their headquarter in the neighbourhood the Ballads grew up in. They described their common upbringing as hard and the ghetto as merciless.

The Ballads were formed in 1961 and Jon Jon joined a little later. The first opening was when a local record label discovered them and recorded “Can't See Your Love (For The Tears In My Eyes) Part 1-2.” It was a local hit and Vee Jay took it up in 1964, just a few months before they went bankrupt. So they received no money for it, they remarked. They started their own business and in 1967 they had saved up enough money to start the Soul Trip label and produce “The Right Track" themselves. It sold decently and became a regional hit and they toured the West Coast.

In 1968 they produced "God Bless Our Love" which was released on the Bay-View Records. It was first recorded by Gene Chandler (1964) and Ballads had done the song on stage for years before they finally went into the studio. The mainly black population in Oakland, across the San Francisco bay, bought 10,000 copies. It became a local hit and Venture Records picked up the group. Bob Relf produced a remake, which sold very well all over the US and all, not least their manager Joe Baker, who was also in the studio, felt that they were on their way to the top.

Sure, the Ballads were a good group. But when one heard Bob Relf instruct the group's lead singer, and he showed exactly how it should sound, one could only conclude that Relf was by far the greatest singer ...

But The Ballads were not satisfied with the financial terms. They 
were dressed in T-shirts and drove a used Ford, while Warren Lanier, who was also black and Mickey Stevenson, had new Cadillacs parked outside the studio.

I also met Willie Hutch. He belonged to the Venture staff of producers and songwriters. He had previously been with the Kent label and I had heard a couple of nice records with him.

An energetic and muscular young man, who worked as an office janitor and took care of the mail room and internal post and did various errands, presented himself as Terrible Tom. He played his first record for me - "We Were Made For Each Other" / "Lovin 'Cup” on the Maverick label - a sub label of Venture. He was also a boxer and youth adviser. (This record has later gained cult status among the so called Northern Soul fans in England). Tom presented his very beautiful wife, Lauretta Bowden, a singer with the group Naturelles, that had great success with "Show Me the Way."

Rochelle Reed had described Larry Williams as a shrewd businessman and he had been employed at Venture as an A\&R man. I wanted to interview him, but he had no time. He, Terrible Tom and two of the Naturelles, went to the parking lot for a quick photo session.

Terrible Tom Bowden was born in 1940 as the first black child in Portola, a completely white part of town where his mother worked. It stormed that night and she had nowhere else to go. Tom got his nickname in the Oakland ghetto where he grew up. He went in and out of reform schools and was a feared street fighter. Professional boxing was a logical first career step and 
he had retired undefeated after fifteen knockouts in seventeen fights.

Tom remarked that he had never smoked or drank alcohol. He was a first cousin to the late Jessie Belvin, and was now fully committed to a singing career and fought his battles in talent contests between the city's east and western parts.

He described his singing style as a mix between Otis Redding and Wilson Pickett. He had been touring and performing in the same venues as Aretha Franklin, The Temptations, Four Tops, Jackie Wilson, Little Richard and The Ballads.

But his stage name no longer did him justice. In his free time, he was a youth consultant and had had great success with incorrigible ghetto youth. They knew that he was one of them and had the same background. He had also sung in the San Quentin prison and if he became a big star, he would build a recreation center in the middle of the ghetto. There he would perform at least once a year completely free and offer free food so everyone could come.

Tom told me that ex-boxer Jimmy McCracklin was appearing at the California Club Soul on Friday-Saturday this weekend. The club was located at Santa Barbara (avenue?), close to Western Avenue.

Thursday, August 8, 1968

By bus I was back in Hollywood again and first went to Columbia Records in 6922 Hollywood Blvd. But my contact, the PR man Timmy Owens, was at 6121 W. Sunset Blvd. On the 
way I passed by Dot Records, but they had no Soul music in their catalog.

My main goal however was Minit Records at 6920 W. Sunset. This New Orleans label had been purchased by Liberty-Imperial and had been languishing for a while. But Minit had been reactivated and made into one of the West Coast's best soul music companies. It had an impressive roster of artists including Jimmy Holiday, Bobby Womack, Ike \& Tina Turner, Homer Banks, the Players, and Jimmy McCracklin.

At Minit I met promo man Tom Riney. He seemed to come from a good background. He was relaxed, well-dressed, and friendly and maybe on the way to a management post. But he was lacking in musical interest and knowledge.

He introduced me to the producer Dallas Smith. He seemed like a typical southern record man like Dan Penn or Marshall Sehorn. He was white and maybe thirty years old, but the stress and the pace was higher here, and yesterday's sleeping pill had not worked, so he took one more. Today he felt washed out. We discussed soul music and went through the different artists that were in the Minit-stable. Dallas arranged a meeting with his protegé Gloria Jones the next day.

Dallas liked the lyrics of Jimmy McCracklin. He quoted "Let the back door hit you where the dog bit you," as an example of Jimmy's poetic ability. Still, this particular line had been used previously by Bo Diddley ... Tom Riney drove me back to Los Angeles. It took a long time in the afternoon when freeways 
were full. I got ready for a tough program this evening. I was due to meet three different Minit-Liberty artists.

Many record companies in England had begun to release soul compilations. On Minit label collections, Bobby Womack could be heard with an odd but excellent track. Otherwise, he was a relatively unknown name in Europe. His latest, "Fly Me To The Moon," was one of the best soul singles this summer. It was just about to enter Billboard's Hot 100. I also knew that the Valentinos made the original to the Rolling Stones "It's All Over Now.” But I had never heard the song.

Tonight Bobby produced an LP with Jimmy \& Vella and not far from it Ike \& Tina inaugurated a new soul-club. Bobby, a lefthanded guitarist, sat in a corner of Liberty's large studio and instructed Jimmy, the guitarist and singer. It would have been better if Bobby had played guitar on the album. Bobby said that he used the guitar when he composed.

They had been advised of my arrival and stopped the tape after a while. Bobby was talkative and friendly but also a bit rushed and stressed.

The siblings Jimmy \& Vella (Cameron) was launched as black "flower-children" and Jimmy spread some "peace and love" platitudes around. But he was not a new Scott McKenzie or a Byrds member, so it fell to the ground. During this round trip I had not yet encountered artists that had been instructed what to say by PR-people. In Los Angeles, things were obviously more planned and commercial. "Lucky Pierre,” or Robert Appère (436 
S. Oakhurst) was Jimmy \& Vella's manager. He was also the program director at KGFG.

Unfortunately, Bobby Womack did not make any personal appearances in Los Angeles at the time, but we had a chat between takes and then he took me out to the parking lot to take pictures with his Porsche.

He was born in Cleveland, Ohio March 4, 1944 and had four brothers: Friendly (27 years), Curtis (25 years), Harry (22 years) and Cecil (20 years). They grew up in church and in the mid-1950's formed a gospel group called the Womack Brothers. Shortly afterwards they were discovered by Sam Cooke, who then sang with the Soul

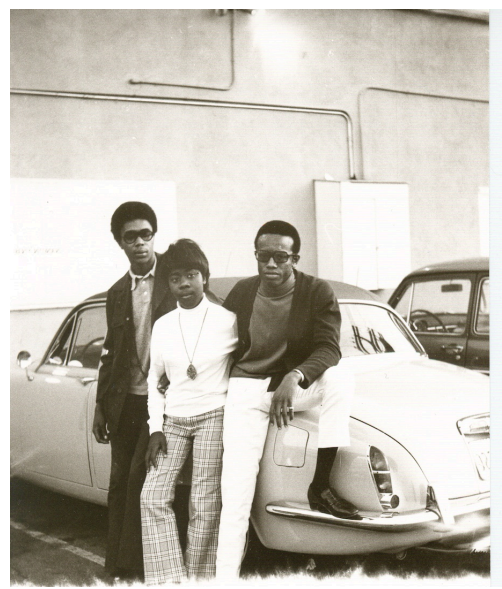

Bobby Womack

Stirrers. He was impressed and helped the group to get gigs and took them on his tours. The Womack brothers were then so short that they sometimes had to stand on fruit boxes to be seen and reach up to the microphones.

Sam Cooke started his own record company SAR and contracted the Womack Brothers. He produced their first record, the gospel song Somebody's Wrong where Bobby sang lead. It was a small local gospel hit.

They lost touch when Sam began singing R\&B. But Rosco 
Robinson, who succeeded Archie Brownlee in the Five Blind Boys of Mississippi, after his death, contacted Sam who said Womack brothers must change the style and become R\&B artists if they wanted to record again. After a lot of thinking they finally said yes. Bobby described the transformation as rewriting gospel song lyrics into pop.

They changed their name to The Valentinos and their first disc was Looking For A Love / Somewhere There's A Girl which sold 450,000 copies. Next was I'll Make It Alright / Darling Come Back Home, which sold 100,000 copies. Sam was disappointed and asked Bobby to write something of his own. Together with Cecil he composed "It's All Over Now" / "She's So Good To Me," which became their third record. It sold 450,000 copies and the Stones cover, which was released a short time later, sold 900,000 copies. The Rolling Stones were avid record collectors and had probably heard the record during a USA-tour in 1964. Bobby had nothing bad to say about the Stones or felt that they had stolen prospective buyers of their original.

But he said that they misunderstood the lyrics. He sang: "She hurt me nose open - that's no lie " and said that the Stones had changed it to "She hurt me eyes open ..." To have one's "nose open” means that one is vulnerable, while having one's "eyes open” means something else. When I heard the Valentinos' original a few weeks later, I noted that the Rolling Stones, after all, had done a very fine job, unlike many other British cover bands.

Their fourth record "Baby Lot's Of Luck” sold a more modest 
80,000 copies. Bobby knew the sales figures. Only he and Roy Hamilton did that summer. I guess that Sam Cooke was honest and didn't underreport sales like so many others.

The Valentinos got their first engagement as a $R \& B$ group at the Apollo Theatre. They were so afraid to meet the demanding Apollo crowd that they could not move, and dancing was considered sinful.

When their fourth single flopped Sam wanted Bobby to be his guitarist. Bobby persuaded Sam to take the group on tour. The Valentinos opened the show and then Bobby changed his clothes and was the guitarist with the Sam Cooke Orchestra. He made more money playing guitar than singing with his brothers.

Sam Cooke was murdered in 1964 and the group disbanded after ten years together. Friendly and Curtis were already married and had families and rather stayed at home. Cecil was about to marry Mary Wells, Motown's first big female soul star. One of the brothers had a record store that needed to be managed. But Bobby continued to tour and was Ray Charles guitarist for two years. He started his own music-publishing "Trace-Bob Music” in 1964 and continued as a solo artist and recorded for Checker ("I Found A True Love and A Lonesome Man”), and then for Atlantic: "I'm Gonna Find Me Somebody" that the Box Tops later took up. He also recorded "I Can't Stand It” - and neither did the audience, said Bobby.

He felt that he had not been very successful - either as a performer or composer - when Wilson Pickett in 1966 took Bobby under his wing. He wanted him as a session guitarist and 
recorded some of his songs as B-sides. Pickett wanted Bobby to record in Memphis where they had more gospel feel. Bobby began writing for Wilson and also instructed him as he could not read music. Bobby was included in Chips Moman's staff and when the Pickett session was over, Bobby recorded his own song. It usually didn't sell, said the self-critical Bobby.

When Wilson began to have great success with Bobby's compositions “I'm In Love," “Midnight Mover” and “Jealous Love,” Bobby regained his confidence. He had also written songs taken up by James Carr and Jerry Butler and others and been a producer for Rosie Grier on Bell Records. (The former football star whose "People Make The World" was heard much the summer).

He got a contract with Minit Records and his first record Broadway Walk sold a modest 40,000 copies. What Is This sold 90,000 and "Fly Me To The Moon" had sold 80,000 in two weeks and gotten airplay in all the cities I visited. Other minor Minit sellers had been: “Take Me” and “Trust Me.” He thought the Womack brothers would reunite again on record.

Great things also happened in his private life when he married Sam Cooke's widow. He remarked: "Sam and I were such close friends that I really just continued where he left off” and "A woman is a powerful thing," "That could be the title of my next record.” With those words we parted by his Porsche. It had belonged to Sam Cooke before. Bobby Womack was one of the greatest male vocalists in soul-history and a marvellous gospel guitarist too. 
I was in a hurry because my greatest female soul favourite Tina appeared with her husband Ike Turner nearby. I had looked forward to this for more than three years.

The Ike and Tina Turner Revue

Ike \& Tina, who lived in Los Angeles, opened a new nightclub and were booked for a week. In my notebook I had written California Club West and the address 8265 W. Santa Monica. I think a woman named Rhonda was the manager of the club. There were two (?) California soul clubs in the Los AngelesHollywood area. The day after I visited the California Club Soul where Jimmy McCracklin was appearing.

California Club West was a simple nightclub without unnecessary luxury. It was located in a low building with entrance from the street and had a paved parking lot at the back. I paid a couple of dollars in admission at the door and the drinks cost one dollar. The longer the drink lasted the better for me. I got a small table without a cloth in the middle of the room that held perhaps 250-350 guests. The audience was around two thirds black. Behind me to the right was the bar and there was an exit to the left of the stage which led to the parking lot in the back of the house.

There were not many people there when I arrived but when showtime approached the club was packed. On other evenings some tables stood empty. Although Ike and Tina were known throughout America and had maybe 300 gigs per year, it was two years since "River Deep Mountain High" had peaked at no 88 in the Hot 100. 
After such a long time with such a small hit in USA you were considered a has-been and it was this kind of midsize clubs they performed at today. In front of a 100-200 spectators during weekdays and perhaps the double during weekends.

But appearances are deceiving - it was here that I saw the best soul-club-concert I've ever seen and unfortunately probably will ever see. Ike \& Tina Turner was a national soul band. Since the late 1950s they had toured from coast to coast. I knew that Ike had been working even longer - as a tireless bandleader, talent scout and fixer.

Many had taken their first steps in the industry under his wings. In Chicago's soul world where the old Ikettes Jo Armstead was working in the music industry and Eddie Silvers wife Mary Brown had recorded at One-derful! records. The Sharpees consisted of the old Ike Turner protegées Stacy Johnson and Vernon Guy. But Ike had begun in the 1940s and had the credentials and experiences from the blues and R\&B world that makes these relatively unknown soul artists fade in comparison.

There was movement on stage and after a brief presentation The Kings Of Rhythm, in black suits, started to warm up the audience during half an hour. They were six men and played various instrumental soul-hit songs from the past years. This first part of the show was pretty uninteresting.

After a fifteen minute break the lineup was strengthened by an organist. The pace was picked up with two fine versions of this summer's major instrumental hits, Cliff Nobles' "The Horse” and Hugh Masekela’s “Grazing In The Grass” and this set was 
rounded off with a fine instrumental version of Major Lance's "Monkey Time."

At the end of this set a man in a red suit and a well-groomed Beatles hairstyle plugged in his guitar. He was a striking contrast against the black-clad men.

It was Ike Turner and his entry on the stage, and the deep, wooden, reverb-rich guitar sound raised the temperature many degrees during "Monkey Time.”

His sound was a mixture of Johnny "Guitar” Watson and Steve Cropper's Memphis Stax sound. Ike's playing style and philosophy - rather fewer notes than more and better in the bass than in the treble - appealed very much to me. He started playing what sounded like the intro to "You Left The Water Running" and we understood immediately that this would be very good.

The Kings of Rhythm consisted of the following seven members:

Jesse Antoine (trumpet) was born May, 11946 in Liberty, Texas. He had played with Ike Turner for one month.

Edward A. Burks (trombone) was born December 12, 1942 in Dallas, Texas, and had previously played in the Watts 103rd St. Rhythm Band. He also wrote down "Sportsman" and "Freemont High School” and I assume that the first was a club he had played in and the other a school he attended.

James R. Lockett (tenor sax) was born February 16, 1942 in Houston, Texas, and had been with Ike for three months. He had 
toured with Garnet Mimms, Rufus Thomas, Dionne Warwick and Wilson Pickett. Garnet was the best, he thought, while Wilson was a madman who always wanted it his own way. But it was usually the right way and he paid well.

Leon Blue (piano, organ) was born September 19, 1931 in Wichita Falls, Texas. He had been with Ike for two and a half years and during that time in England twice.

Odell Stokes (guitar) was born February 17, 1945 in Tulsa, Oklahoma. He had been with Ike for four years, including in England.

(Edmond) Lee Miles (bass) was born May 23, 1949 in Los Angeles. He had previously played with Bob and Earl, and since two and a half years with Ike. He had also toured in England.

Soko Richardson (drums) was born December 8, 1939 in New Iberia, Louisiana, and had been with Ike for three and a half years.

Time for Bobby Barnes, qualified from his time with The Platters, the later edition that recorded for Musicor. They are best known for the songs With This Ring and I Love You 1000 Times. Bobby had been singing on both these hits, he said, during two sessions, even though he only stayed with the Platters for six weeks. In 1967 Bobby recorded "Two of a Kind" / "The Skate on Crosstone" before he was discovered by Willie Mitchell, who produced "I Shed A Tear" / "Times Are Bad" which I believe were released on the Discovery label. Bobby lived at 2235 East 115 St. in Los Angeles and had only 
been with Ike \& Tina for three weeks. On stage, he did OK soul versions of Stax and Motown songs like "I Wish It Would Rain," "Knock On Wood,” "I Could Never Love Another.”

(I made a note that a second male performer did "Respect," "You Left the Water Running” or "Soul Man” and Otis Redding's “I’ve been Loving You Too Long,” but it may also have been Bobby Barnes second set.)

Then three incredibly stylish young women entered the scene. It was The Ikettes and they did "Soul Serenade," "Sweet Inspiration" and "Shake a Tail Feather" in a lightning fast pace and with good humour. Especially the last song gave the three girls great opportunities to show their physical advantages. Those were quite visible since Ike, when it came to costuming, obviously only worked with two different concepts: either short skirts or hot-pants. These women had every advantage to be able to bear these uniforms.

How on earth could Tina withstand this competition? No sooner had the audience time to take a breath after this explosion on stage when it was time for Tina's entrance in leopard mini skirt and high heels. 


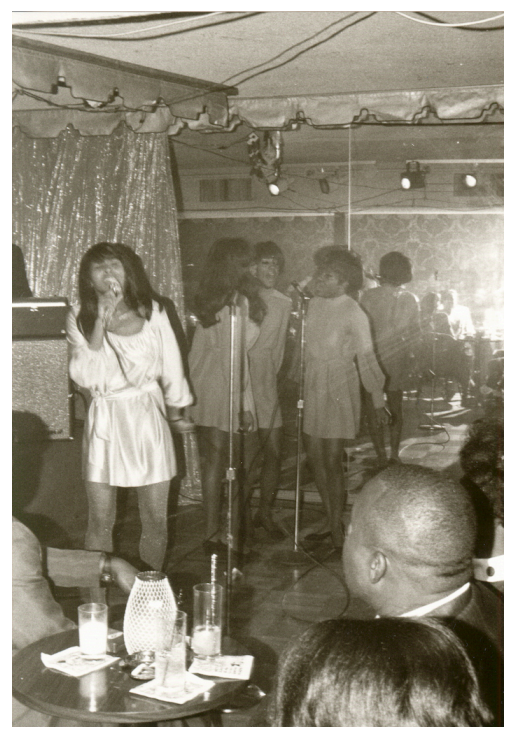

Tina Turner and the Ikettes
It is an impossible task for me to try to describe and do justice by Tina on stage. I know that many will be disappointed but I dare not even try to describe in detail what she did. I was soon in a higher state of consciousness where the mind had stopped working. But the live LP at Minit recorded around 1968, has the same repertoire and gives a good, albeit very pale image.

Along with the Ikettes, who remained on the stage, and almost as a member of the group, Tina did "So Fine," and she also gave the Ikettes a more prominent role in "Goodbye, So Long” and “A Fool In Love” that followed. Between songs, Tina said "You don't want to put your troubles in the street, but I have a husband and all he does is cheat ...” And Joy replied: "If I had that man I would shoot him.” When she presented "her” vocal group Tina said "If they were not great, they would not be with me. I'm not bragging - I speak only the truth.”

Then Tina took center stage and the classic duet with Ike - "It's Gonna Work Out Fine” - followed as did Etta James’ showpiece “All I Could Do Was Cry” with a long monologue. 
Tina's humour, self-irony and extraordinary soul voice made the Ikettes float away in the background. She was as much at home with male or female soul hits such as Wilson Pickett's “Funky Street" and "Land of 1000 Dances” or Aretha Franklin's “Since You've Been Gone,” “Think,” "Baby I Love You," "Respect” and “Natural Woman.” And on their own or others' hits like

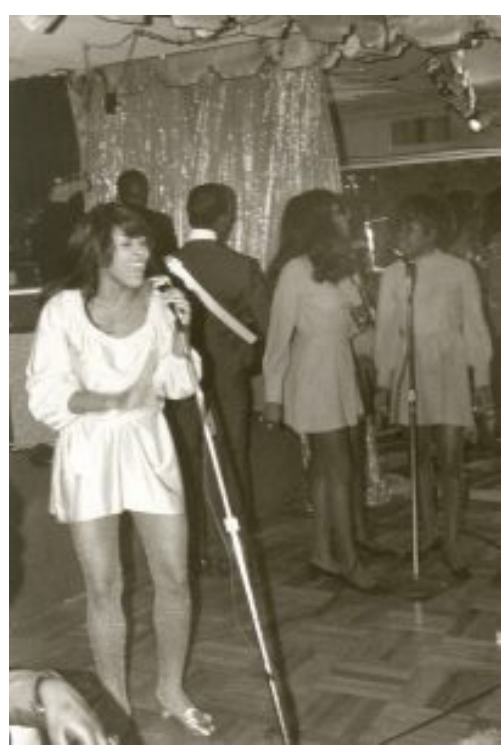

Tina Turner “A Love Like Yours Don't Come Knockin’ Everyday,” “Tell The Truth.”

"River Deep Mountain High" sat well despite the lack of Spector's Wall of Sound, and she imitated James Brown at "I Got The Feeling."

This flat chested, skinny woman - a role model from Joe Tex' "Skinny Legs And All" - had in no time eclipsed the Ikettes more plump beauty queens.

I saw five different performances. Some songs were replaced, but the finale was always the same: Tina sang "Please Please Please” - James Brown’s first hit and his signature song.

In the spring of 1965, I bought this Ike \& Tina's single at Sue Records from England. The reason was a picture of the duo in 
the English musical weekly Record Mirror. They stood facing each other, oblique in profile. You can see Tina's beautifully curved nose and high cheekbones. Both are lean and look incredibly charged - like two greyhounds before a race. Obviously an industrious and hard-working couple. I had never heard them sing, and it was probably the first time I bought a disc after seeing a picture. But when the yellow-orange label lay on the turntable, I was within seconds completely lost for my surroundings and it took a couple of days before I woke up from the trance.

Soon, it was discussed among friends in Lidingö whether Tina pronounced her name “Tiina” or “Tajna.” I voted for the latter pronunciation. At the same time, I got in an argument with a clerk at the department store pub in Stockholm. I discovered the cover of their Loma/WB album on display. But they could not find the disc. It was just an empty sleeve ...

"Please Please Please” by Ike and Tina is perhaps my all-time favourite recording. (The best of the upwards of half a million different songs in all the categories I've heard for sixty years.) But it should be in the slightly shortened version where Tina does not talk so much. The recording loses speed on the longer version in which she slips into the Etta James monologue from “All I Can Do Is Cry.” Then Etta very realistically, but probably unintentionally, was portrayed with bandages around her wrists on the cover of the Rock the House LP.

Etta, who also lived in Los Angeles said about the Turners in her autobiography Rage To Survive - "Ike was something special. I know he was a tyrant ... He was a magnet for women - 
including me. His dangerous exterior and his violent music made him even more attractive. Ike was strong. Tina was like a bird in a cage. Too afraid of the world around her and Ike for daring to move. She did everything for Ike. She loved to show her closet and tell us what Ike had bought her. But I knew that the clothes were stolen by other women who were in love with Ike.”

I had previously only seen the duo perform in the film that followed up the TAMI show with James Brown's sensational appearance, but where someone had come up with the idea to dress the duo in Santa Claus head gear. (Tina singing "Please Please Please” was not in the film I saw.)

Anyway - back in Hollywood - my legs gave way and the consciousness floated away to a better world when Tina started. I was a floored every time Tina finished the song after her talking part "I want to hear you say aah, Aaaah, Aaaaaah - Baby Please !!!” And I was brought out of the trance when Ike struck his guitar in "Grumbling," a cover of Freddie King's "Stumble," from the Blue Thumb LP where the couple is eating watermelon on the cover.

Tina and the Ikettes danced frenetically to the blazing stroboscopic light while Ike made a perfect interpretation of the Freddie King song. Perhaps he was even better than the great Freddie..? (Ike had also done a matchless Pat Hare imitation on All the Blues All the Time on his Crown LP. What a brilliant musician!)

During the break, I went up to Ike. He had gone out through the back-door to the paved courtyard behind the club. He stood 
there in his red suit and his Beatle haircut surrounded by his black-costumed musicians. Both on and off stage there was no doubt who was the band leader. I think they were talking about gambling and that there was a card game going on somewhere. Ike seemed very businesslike. I complimented him for a brilliant show and he grunted something in response. I asked him if it was all right to talk to Tina. Sure, he said, but you cannot take any pictures in the dressing room.

The dressing room was a corridor-like and perhaps 1.5 meters wide and 2.5 meters long room. All the Ikettes sat neatly lined up against one wall and in the corner nearest the door sat Tina. Everyone was wearing black underwear panties and a bra nothing else. I suffered a vertigo attack and fell into a chair opposite her, completely dazed and gasping for breath. Summoning my last strength I tried to keep my eyes fixated above Tina's shoulders. I took out my notebook and introduced myself as the European reporter of the English soul magazine Blues and Soul. Then I also felt like taking off my shirt that was already soaking wet. It was hot! I was burning up!

Tina calmly explained that the dressing room was next door to the kitchen which had specialized in a menu of fried chicken and French fries and the frying pots were next to the wall, and working at full heat. The room must have been 45 degrees Celsius. Now I understood better why Ike asked me not to take any pictures ... I have no memory of the men's locker rooms more than that it was bigger and that there was a card game led by Ike. That's where I interviewed the Kings Of Rhythm. After a while Tina's sister dropped by. She said that Tina's kids were 
allright. "How many?” I asked? “Five,” said Tina. (All boys and aged 7-8-9-10 years, etc.). The family had lived in Los Angeles for five years and their current address was 4263 Olympic Drive. The sister also lived there and took care of the children when the Turner family were touring

I informed Tina that I had met former Ikette Mary Brown's husband Eddie Silvers in Chicago, where he was the arranger and producer at One-derful! Records. Tina said that she and Mary talked on the phone as recently as last week. Mary was one of Tina's oldest friends. I also tried, rather incoherently to make Tina understand that I considered her to be the greatest female artist in the USA today.

How was Tina behind the stage? Was she equally vulgar and sexy as on stage? Did I try to take off more clothes than my shirt?

The truth is that Tina was simply the most timid, shy and reclusive female soul singer I met that summer. I noticed that she became a little sad or annoyed when I asked her if she used a wig - another of my many blunders that summer ... And it was not easy to even try to interview her because she was so quiet.

The Ikettes consisted of Esther Burton who sang lead - and she was perhaps not as remarkable beautiful as the other two. She was born on the 4th of February 1945 in the Midlands, Texas. Her background was gospel and R\&B.

Joy Lennear, the group's 21-year-old, long haired (a wig?) beauty queen was born in 1946 in Providence, Rhode Island. She 
had a gospel background and had previously sung with the group The Superbs. Her recording debut was One Bad Habit on the Dore record label.

Ethna Wood(s) was born August 23, 1949 in Akron, Ohio, and had previously worked as a beautician. She had sung gospel and her professional start was in the group Soul Sensations.

This was the eighth version of the Ikettes since the start. They had been engaged by Ike just four or five weeks ago.

Ike was obviously a magician when it came to directing and putting on a good stage show in no time. The singing was of course OK, but how had they been able to synchronize all these complicated dance steps? How had they learned all these dance crazes? Why was Ike not recruited to choreograph Grease on Broadway? Or used as a role model for the musical Fame?

Why was not a musical made about his life? Why was a TV episode (in the series Ally McBeal), about how Tina Turner, as a judge in a contest, determined who could be a Ikette. I guess Ike always had the last word in that process.

The Ikettes were certainly the most visually appealing group in the same genre as the Raelettes, Bland Dolls, Otisettes, Sweet Inspirations, etc., and their incredibly energetic stage show and uninhibited sexuality overshadowed that they have never been particularly prominent singers. It was not a natural nursery for a solo career, but an exception was P. P. ("First Cut Is The Deepest”) Arnold, who left during a tour in England last year and performed with The Nice in England. Vanessa Fields and 
Jackie Smith were two of the first Ikettes and they knew Tina as Annie Mae before she was Tina. They were later back-up singers for Dr. John and Humble Pie.

\section{Postscript}

Forty-eight years have passed, but I have often wondered why I thought Ike \& Tina Turner were so good. Tina was her generation's foremost female stage performer, but today she is a shadow of her former greatness, and it has been a long time since I heard her singing "Please Please Please.” When one delves into Tina’s past you will find Ike there.

I think that without Ike, there would never have been a Tina. He created her as an artist - layer after layer, until she finally stood there like the white audience's ultimate wet dream. She was the uninhibited black woman - A native directly from the wilderness. These sentiments have been exploited among white intellectuals for many years. (The Swedish Academy handles the Nobel awards. Its member Artur Lundkvist has written books like “Negro Coast”(1933) and "Negro Country" (1949), for example).

Most of the major black artists in blues, R\&B, soul and gospel are the same both on and off the stage. They are simply themselves all the time. Lightnin' Hopkins and B.B. King live ordinary lives off stage and tell musical stories about their own experiences or what friends have told them. It also applies to Roy Brown, Ruth Brown or Joe Tex. Tina is an exception to that rule. On stage, vulgar and outgoing, but behind the scene 
incredibly timid, reclusive and shy. Just like an actress with Ike Turner as a dictatorial director.

They were on top right then. There were no weak points in their stage appearance. Tina's voice was strong all around. She could sing anything without signs of fatigue or hoarseness. The stage show was perfect. They were simply America's best live act in all categories. The biggest problem was probably the lack of their own song material.

Whenever appropriate I asked other artists about James Brown and Ike \& Tina Turner. Most of them described Ike as difficult. Eddie Silvers, who worked at One-derful! in Chicago stated frankly that Ike was a bad person.

I did not realize then what a huge role he played in black music after World War II. Today he personalizes the myth of the pimp and Ike is a negative role model. Tina's description of him as a woman-abuser still overshadows his unique qualities as an artist.

I wanted to see Ike and Tina every night but it was many miles by bus from Hollywood to the center of Los Angeles. When the show finished, busses had stopped going and I had to hitchhike. The first night George Grant drove up with an old, used car and offered a ride which I gratefully accepted. He was a kind man, but his agency was probably not doing too well. But the other two evenings I had to hitchhike back. No one present then can accuse me of homophobia if I state that the first driver was apparently out at night only to pick up hitchhikers. The last night I ended up in the same car as a Hells Angels type with visible 
drug use. The serial killer was an unknown phenomenon then, but these two types would have set alarm bells ringing today.

The second evening, the club owner announced that James Brown had called. He was in Los Angeles and wanted to come and see the show tomorrow. The chance to see Tina and James do "Please Please Please" together kept me sleepless much of the night. To me this was comparable of seeing Elmore James in a southern juke joint with Guitar Slim in the audience sitting in on a couple of numbers. But James Brown never came, unfortunately. I had to wait a week to see his show in San Francisco. James Brown writes in his autobiography, The Godfather of Soul (1986) how he first met Ike and Tina in California. James does not often praise his colleagues, but he remarked that Tina knew what she should do on stage. Tina had taken over from the Famous Flames, and done everything that James did, and finally jumped down from the piano in a split. The show ended with both singing Please Please Please standing on their knees. It had already happened... and later James concludes "It is strange that no one else can make anything of this song (Please Please Please). Neither the Five Royales, Ike and Tina or Barbara Lewis “.

But I still think that Ike \& Tina have made the very best recording of this song. Tina's extraordinary monologue at the end of the song makes this a statement of her unhappy marriage to Ike while James Brown, with the biggest ego in the business, falls on his knees begging himself to stay longer on stage. That's my impression when I compared the two performances in San Francisco later. 
I saw The Ike \& Tina Turner Revue five times. The shows were not identical. Some songs were replaced but the structure was the same. They were just as good every time. This was pure routine for them - they did it 365 days of the year ...

Ike Turner was a great band leader, and when it comes to setting up and directing a R\&B and Soul Show I think no one was better in the 1960s. Aretha Franklin was obviously a better singer than Tina, but as a stage performer Tina was far superior. A decade of tough tours seemed to have gone unheeded. The great Betty Harris had a similar history of tours and recordings as Tina but seemed worn out and older compared with the blossoming Tina Turner.

The married couple Turner did not socialize much offstage. Tina often sat alone by herself in the dressing room during breaks while Ike moved around in the club. I rushed to her after visiting Motown's West Coast office. The Temptations manager had talked very appreciative of the duo. Then she sat engaged in a serious conversation with a male friend, or perhaps relative. Their commitment was extended one week, and then they went to San Francisco.

I do think that many artists that summer really did their best. Perhaps I was the first journalist interviewing them and I came from Europe. It was a big opportunity. Perhaps the most important so far apart from the recording contract, of course.

Friday, August 2

As usual I was very tired after all the experiences of the day 
before. Today a meeting was scheduled with Gloria Jones (1305 S. Sycamore Ave). She was already in the lobby of the Liberty building (6920 W. Sunset Blvd). She turned out to be the nicest of all the very charming, talented and beautiful female soul singers I met that summer. I took pictures of her outside the entrance, and then we went up to Dallas Smith's office.

Gloria was born in Cincinnati, Ohio, where her father was a preacher. Her great-great grandfather came from Ireland, and she also had drops of Indian blood. Ten years ago the family moved to Los Angeles. Between 1960 and 1965, she sang lead in the gospel group the Cogics (Church of God in Christ - the church her family belonged to). Billy Preston, then marketed as The Wildest Organ In Town, was the

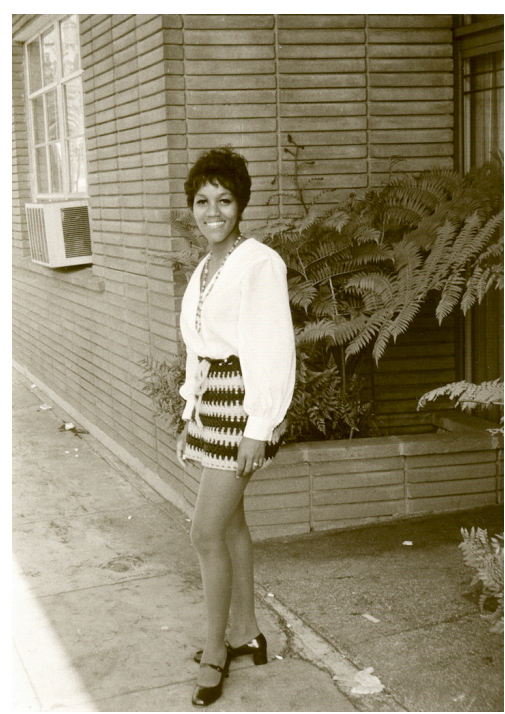

Gloria Jones outside Liberty office Los Angeles group’s organist but also sang at times. Member Blinky Williams was launched as a new rising star at Motown in 1968 (Her "I wouldn't Change The Man” was heard on the radio then).

The group also had a fourth member, Andrae Crouch, who was to become one of the biggest names in modern gospel. (Gloria mentioned only these three, but Andrae's twin sister Sandra (or 
Sondra) Crouch and Edna Wright are usually also counted as members.)

The Vee Jay LP The Blood - It Will Never Lose It's Power, produced by Richard Simpson in 1964, was re-released as Presenting The Cogics on the associated company Exodus. The group dissolved in 1965, and later Hal Davis, from Motown's West Coast office, discovered Gloria. She did studio work and although she never thought about singing soul or $R \& B$ she got a contract with Capitol and recorded "Heartbeat (part 1-2)” for one of their subsidiary labels, Uptown.

The record climbed to the 55th place on the national charts. In a review of the Heartbeat album (1966) a reviewer wrote: "It is hard to believe that the girl who sings is only 18 years old.” Gloria was elected most promising new female singer in Cashbox 1965. Capitol never followed up the success, though. They released an LP but not a 45 .

Gloria studied piano for two years and concentrated on acting. In 1967, she played the role of Bianca in The Rock And Roll Othello which was based on Shakespeare's play and renamed Catch My Soul. The cast had Jerry Lee Lewis in the title role and singing group The Blossoms as well as regular actors. Jack Good, the man behind the Shindig TV show, directed the play and Gloria had visited his TV show as well. They had toured and appeared in Dallas (November 1967). Gloria said quite modestly that she had given life to Bianca, Cassio's black mistress, and after seeing her play a scene, I could only agree. She really had a lot of energy - "except when it’s too hot outside” she assured. 
She continued to do studio work behind several other major artists such as O. C. Smith and Ike \& Tina Turner. Those who bought the Rolling Stones LP, which was released in the autumn 1968 (Beggar's Banquet) can hear Gloria in the background. In 1967 she was contracted to Minit and in 1968 she recorded a slow soul version of Barbara George's hit: "I Know" / "What You Want Baby I Want You.” The sequel, which Dallas now played the demo of was called "When He Touches Me" - an excellent slow burning soul song with "Look What You Started" on the back. Gloria, who became quite emotional, left the room while we listened.

But Dallas Smith was clearly upset when I told him that Rodge Martin had made a nice version of the song on the Bragg label already a couple of years ago, and that Polydor (No. 56725) released the single in England. Even Percy Sledge had made a $\mathrm{LP}$ version. In the patriarchal versions the song is called "When She Touches Me.”

This was not anticipated and the song publisher had asserted that Gloria was the first to record the song. Gloria and Dallas were working on an LP, which was never released, and one of the songs was “Dirty Old Man.” Now, Gloria was hoping to have a role in the television series Peyton Place, and she had auditioned for roles in two films.

After a while Gloria's husband showed up with the couple's small child in his arms. Gloria had bigger plans than to be a housewife, and I could see that she had succeeded to have her husband take care of (some of) the homework. 
Right now she took a summer course in American History at UCLA and was hoping to get her B.A. soon. She was different from the other female soul singers I had met so far. Her perspective was larger and not limited to the ghetto or to the places where the tour bus brought her. She was also interested in astrology but I still did not know what sign I was born in.

This very charming bundle of energy was discovered by Marc Bolan (T. Rex) a few years later. They married (or lived as married) and Gloria drove the car that unfortunate evening when they crashed and he died. I never saw her perform live - she had no gigs at the time. But she showed me pictures of herself from her father's church recently, where she had guested at a recent Sunday. It looked good.

Dallas Smith rang up Jimmy Holiday and introduced me to his wife. But she said he could not be disturbed. He had gone through a major heart surgery recently and was still very tired. Then I took the bus back to Los Angeles.

That evening, I wanted to see Jimmy McCracklin perform at the California Club Soul (1759 W. Santa Barbara/Western). I had first heard him doing “The Walk” on an English compilation EP with Chess recordings several years ago. Looking at the map, it looked like a good half-hour walk there. But one and a half hours later, I arrived after walking through tunnels and running across major highways. This town was certainly not built for pedestrians. One $\mathrm{cm}$ on the map was twice as long a distance as in other cities.

The last stretch, inside a built-up area, I was suddenly stopped by 
an impeccably dressed young boy, probably no more than fifteen years old but looking like a twelve year old child. He had a suit and vest and asked if I had any acid (LSD) to sell. I had arrived in Watts.

A 150-head crowd had turned out at this rather large club. I was not able to get inside for free. Apart from McCracklin the other artists tonight were the Bean Brothers and Betty Bebbs. The resident house band began an instrumental set including Dyke and the Blazers Funky Walk.

The Bean Brothers then opened. Three of the members took turns singing lead, while the group's tallest member had the role of the comedian. It was a very good group, but unfortunately I never had time to interview them.

On stage the four "brothers" did a medley with "Get Ready" / “Soul Man” / "I Wanna Testify” and a song I think was called “It’s Gotta Be Love Everywhere.”

In There Was A Time (James Brown) they were given opportunities to demonstrate dances such as "The Mashed Potatoes," “The Jerk,” “The Boogaloo,” “The Soul Stretch” and "The James Brown."

They performed a little skit about who had the most soul and ended with "I Got The Feelin"” (James Brown) and "I Wish It Would Rain” (Temptations)

The next performer on stage was Betty Bebbs, a slightly overweight woman, who sang: 
“Baby I Love You,” “Here I Am Baby,” “Steal Away” (Jimmy Hughes VJ recording).

She did a blues called, I think: "Right Now It's Late," "Since You've Been Gone” and "Knock On Wood.”

Betty was a fine soul singer, but perhaps too introverted and lacking "star quality" (The ingredient that Tina Turner had so much of). The atmosphere at the club was not very good. The young and good looking M.C. and announcer used his position on stage to make contact and flirt with the women in the audience. Their men became increasingly upset and angry. In the last set of the night, a man in the audience ran towards the stage to beat him up. But was held back by his friends....

Star time!

The emcee got his act together and announced:

"Ladies and gentlemen! We have the great honour to introduce the man who is known from coast to coast, from back door to back door and from prison to prison... JIMMY McCRACKLIN !!” 


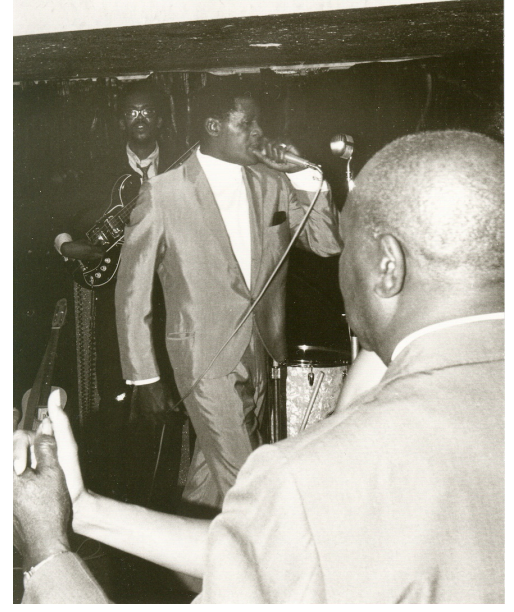

Jimmy McCracklin
I doubt that the MC had invented this ingenious presentation. It was probably signed by McCracklin himself, who however was rather taciturn on stage. It indicates that McCracklin had a slightly different audience than many other soul artists.

On stage, he did: “Steppin’ Up In

Class,” “Think,”“'Arkansas,” "I’m Sorry To You” (Jimmy said it was "number two across the country”), "Just Got To Know from 1961" - but Jimmy said it was from 1963.

Tramp McCracklin invited Lowell Fulson to the stage. He had obviously visited the club and said hello to his old pal but then disappeared. Jimmy had composed “Tramp," and he used the opportunity to say that Lowell had fled when Jimmy was going to show him how to sing this song!

Then Jimmy did impersonations:

A slurring and unsteady Jimmy Reed who sang "Baby You Don't Have To Go.”

A blind Ray Charles who sang "The Other Night As I Lay Sleeping.”

Jimmy finished with James Brown, who threw out cuff links into 
the audience and repeated “Ain’t I Clean” while he, not unlike Liberace, boasted about his new clothes.

During the break, I wanted to talk to the artists. I went to their dressing rooms, but on the way I ran into an unpleasant guy who worked in the kitchen and wanted to drive me away. Finally I managed to walk past him and knocked on the door of a fairly large room.

There sat Jimmy and Betty Bebbs, who was Jimmy’s protégé. He was not that easy to interview, and had many times been criticized of not telling the truth, like for example Sonny Boy Williamson. In Jimmy's case it's mostly been about forgetting his early career and moving his birthdate forward and appear younger than he is. This is what Jimmy said then (I have kept the incorrect chronology etc.):

Jimmy McCracklin was born in St. Louis in 1931 and moved to Minneapolis, Indianapolis when he was nine or ten years old. At the beginning of his musical career he settled in Chicago, but had now moved to San Francisco. He began singing spirituals at home with his mother and sometimes in the church choir (but not singing solo). In his youth he met Memphis Slim who inspired him a lot and when he was drafted he met Lowell Fulson.

But he did not start singing professionally until 1956-57. In the early 1950s he worked as a construction worker ("I dug a hole in the ground”) and sang in the evenings. He began writing songs - always based on his own experience or by observing other people and see what they did. 
Around 1961 he wrote “Tramp” for Lowell Fulson. Joe Tex made a revised version ("Papa Was Too”) but Jimmy got composer's credits for that too. His first recordings were made for Gedinson's (Bob Geddins companies - or Guineson as McCracklin also said).

Crown and later Custom Records had released recordings from Modern. He came to Chess and made "The Walk," which sold two million copies. From Chess he went to Mercury and then to Artone (which was his own label). Now he was on Minit. In addition to The Walk, he had received three gold records, "I Just Got To Know" on Artone, and "Think" and "My Answer” on Minit.

He made long tours being away from his family for 37 to 60 days. He had toured all over the US including Honolulu, Hawaii and had even visited Jamaica and Canada, but not Europe. Jimmy wrote all of his own songs.

He had a lot to write about as he came from a very poor and large family. He had three brothers and twelve sisters, of whom five died at birth. He wanted the lyrics to mean something whether he wrote from his own experiences or of others. He described his songs as "Down To Earth.”

He hated songs where people just screamed and moaned to the rhythm. Apparently, he was referring to James Brown, but he was quick to say that James had made some amazing and soulful records before, and was a really good singer. But right now, James was stuck in the same bag as the kids loved it. 
The imitations were based on his own observations when he toured with Ray Charles and Jimmy Reed. In 1962 he performed with James Brown for 30 days, especially in the Virginia region, but possible also at the Apollo.

His favourites were B.B. King, Lowell Fulson, Memphis Slim, Jimmy Reed and Ray Charles. But unfortunately, the new R\&B discotheque sound (that's what McCracklin said) had put a lot of artists in the gutter. The only survivors besides himself of his own generation were BB King, Bobby Bland, Lowell Fulson plus a few more.

Jimmy had terrible tour experiences. In Atlanta, he was severely beaten by a gang of drunken white people. "The police saved me then," and he pointed to a large scar by his right eye. He also complained of a headache this evening, and I connected it with this beating. In Tennessee a white guy spat on him when Jimmy was sitting in his tour bus, but Jimmy forced him off the road. Jimmy said nothing about his career as a boxer. But it was understood that you could not challenge Jimmy without repercussions.

He had published 22 LPs (including various artists albums?) and about 50 singles during his career. He also produced "They Call You Lover But You Ain’t Nothing But A Tramp” with former Raelette Margie Hendrix. Next week Minit would release McCracklin’s next single "Love Love Love" / "Married Life," according to Tom Riney.

Jimmy produced and wrote material for Betty Bebbs (sometimes spelled Bibbs). She was born in Cleveland in 1942 but later 
moved to Chicago. Her father was a priest and she learned to sing in his church. Her first record First Come First Served was released by Modern. (I think McCracklin said he produced this and that he produced and wrote material for Betty on another couple of singles). She complained of hoarseness and that she had not been able to do her best this evening.

Musically, it had been a successful evening but the bad mood created by the emcee lingered during the long walk home through the deserted motorway landscape. Readers can find the real Jimmy McCracklin Story, on two Route 66 LPs (kix 12 and kix 29) and a Crown Prince LP (ig-405). Jimmy is a very talented artist who in 1968 celebrated his 23rd anniversary (sic) as a recording artist.

\section{Saturday, August 3}

I felt thoroughly tired after yesterday's long walk and did not have enough strength to go out that night. It was also difficult to make contact with the performers on the weekends when the clubs were full of people. In the hotel corridor, quite close to my room on the second floor there was a pay phone on the wall where I used to make or receive calls. In films from 1940s and 1950s you can often see this kind of phone, where I now spent a lot of time.

Lowell Fulson was in town and I called Modern-Kent records to get hold of him. But he was in the studio and recording and was not to be disturbed. He called the hotel later and left a message and his private phone number. But we never met. 
Jimmy Holiday was one of my absolute soul favourites with a fairly long career. Over the years I had picked up his gems on various small labels like How Can I Forget (Everest Records), also recorded by Ben E. King, but now he was securely anchored at the Minit label. Of the lesser known male soul artists, it was actually he and McKinley Mitchell I most wanted to meet and see in the United States.

He was born July 24, 1932 (the official date tends to indicate 1936) in Waterloo, Iowa. He sang a little in the church choir during his childhood and was a boxer for awhile. Ten years ago he had started playing saxophone with his own band The Jimmy Holiday Sextet. They sounded like the Cannonball Adderley Sextet. Sometimes he used to sing, but he had a bad memory and often forgot the lyrics. But he was always able to fill those memory gaps with lines from his imagination.

So he began composing. He could not write or read music but his wife, who was a music teacher, taught him. Jimmy wanted his songs to mean something, and he admired the Beatles a lot. They shared Ray Charles last two singles. The Beatles had the A-sides, while Jimmy had written the B-sides:

\section{"Yesterday” / "Never Had Enough Of Nothing Yet” "Eleanor Rigby” / "Understanding”}

But 1968 had been very unfortunate. When cleaning a gun, it misfired and he lost a finger, and that put an end to his piano-playing. Later, he had heart problems and only one month before, he had open heart surgery (with a heart-lung machine). Now he was on the mend. But he could not see any journalists 
and I could only talk to him for a few minutes before his wife stepped in and said that he must rest. He had stopped making personal appearances a long time ago.

I was very fond of Jimmy's Minit recordings. It was unusual for a male soul artist to openly express melancholy, poor self-esteem and confidence. His album The Turning Point contains some real gems in this field. Jimmy's specialty was soul ballads about unrequited love. His melodramatic performances of conflicting emotions were very convincing.

There had been many soul songs about the Vietnam War, but Jimmy was the only representative of the black right-wing that I can think of. "Help Hurry My Brothers Home,” condemns protests against the war as Jimmy felt they would only prolong it and weaken the USA. Hopefully this disc sold poorly....

Sunday, August 4

I continued to correct and rewrite my interviews, and in the evening I went to Club Mardi Gras (2424 Wilshire). It was only a 20-25 minute walk from the hotel. I guess if this walk had taken place twenty years earlier, and I had continued walking on Central Avenue, I had passed some of the legendary clubs on Central Avenue, like:

Club Alabam, The Plantation Club, Lincoln Theatre, Barrelhouse Club, The Brown Bomber, Lovejoys and Bird In The Basket.

And ten years before the Californian Club, Club Morocco, 5-4 Ballroom, Oasis Club, Zenda Ballroom had been there or nearby. 
I arrived at seven o'clock, and when I came through the door the house band pumped out the closing riffs from Larry Williams' "Slow Down" or another of Larry Williams hits. It sounded just like the excellent live recording with the Stormsville Shakers that he had done in England.

But it was his last number tonight!

This was bad luck. I had never understood that the show started already at six o'clock in the evening. I only saw Larry receive the applause on stage and then shook his hand and exchanged a few pleasantries before Larry was on his way elsewhere. He seemed to always be on the go.

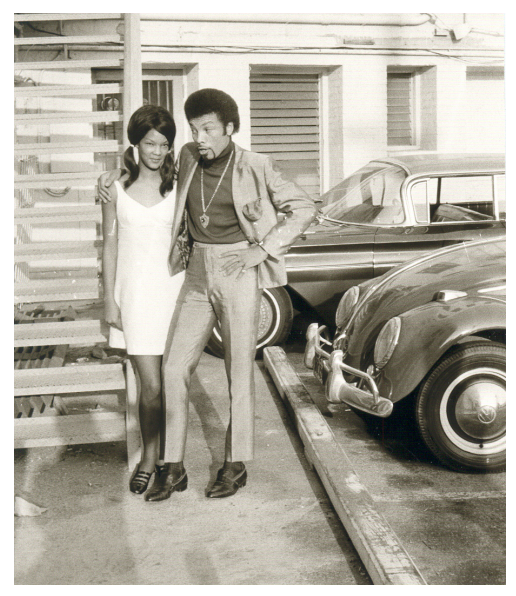

Larry Williams with Lauretta

Bowden from the Naturells outside Venture Records
I wanted to ask about his Chess recording "My Baby's Got Soul," his personal favourite recording. Larry showed that he could sing soul on this fine and interesting recording, from the transition period between $\mathrm{R} \& \mathrm{~B}$ and soul. It was recorded in Los Angeles in 1959 with Plas Johnson on flute. (He later did the sax solo in the Pink Panther films.) Larry was many years ahead of his time and not just a Little Richard impersonator.

The Mardi Gras had an extensive non-stop program with many 
interesting performers this evening. Which made interviews difficult.

House bands tonight were the Watts 103rd St. Rhythm Band, alternating with the "Bet-Tones," the regular house band. Brenton Wood was there as well Bennie Conn and Roy Brown. In between there was a ventriloquist with a puppet show called "Rich and Willie." The doll made a decent vocal version of Sunny. Miss Watts was crowned in a black beauty contest. It was a process that took time.

But even here, the atmosphere was not friendly. In the South and in Chicago, I had always felt welcome everywhere, but now towards the end of the summer, there was hostility. A young man sitting opposite me at the same long table seemed quite $\mathrm{OK}$, but still kept on putting out his cigarettes in my beer glass ... and I could do nothing but pretend I did not see it. It was not the right place to start a discussion. When I tried to talk to a couple of the beauty queens they just turned the other way.

The Watts 103rd St. Rhythm Band did a fine set of original songs and current covers. It was a good band, but too funky for me to be top-rated. I talked to James Gadson, the group's drummer (1657 So. Longwood). When he sang he changed place with the guitarist who sat down at the drums, but there were more instrumentals than song numbers tonight. He advised me to visit their current record label Warner Brothers at 4000 Warner Drive, or meet their producer Fred Smith at 7400 Fountain Ave. Previously, the group had been on Keyman Records and had a hit which he called "Honey" (but it was titled "Spreadin' Honey”). 
Bennie Conn was a good soul singer with a local hit "I'm So Happy To Be Back Home,” which was often heard on the radio in Los Angeles. He sang this song and a couple of soul covers accompanied by the Bet-Tones. I wanted to interview him and he said OK. But Brenton Wood started singing so we had to settle for exchanging addresses at the bar. (Bennie Conn, 8706 So. Normandie, \#5, Los Angeles)

Brenton Wood may not have left a large footprint in music history, but he had actually had four big hits on the Double Shot label during the last twelve months. Strange, because each new hit seemed like an exception confirming that he was a onehit-wonder. His performance was very professional. He had a brilliant falsetto technique. But he was seen as a gimmick singer and not as a serious doo wop or soul singer anymore. He had sung with groups like the Doo Tones, Quotations, Kent \& The Candidates, and with Shirley of Shirley \& Lee fame. Shirley \& Alfred (=Brenton) had recorded Kid Games recently.

His performance: “My Girl,” “Some Got It Some Don’t,” and his hits - "Gimme a Little Sign" and "The Oogum Boogum Song."

Then he left the club. He was much better than expected.

Roy Brown appeared towards the end of the evening. He had recently had a minor hit with "Separation Blues" that I first heard on the radio in Houston. I knew his name from before and had heard some of his old recordings (“Hard Luck Blues”). There were only time to shake hands and exchange addresses, 
but he never answered the letter. He lived at 3863 So. Hobart LA. He had moved from there when my letter arrived.

He made a perfectly OK version of "Separation Blues.” But he never really got the space to display the outstanding stage artist and singer he was. I could not perpetuate the evening on film. I had made the mistake of buying a roll with 24 images instead of 36. I remember Roy wearing a long black coat. I don’t think he even removed it. He went on stage with it, and then spent a short time at the bar and left.

Monday, August 5

Gloria Jones had arranged a meeting at 1:30 pm at the Motown's West Coast office, located at 6290 Sunset at the corner of Vine. But I got stuck in a traffic jam and had misunderstood the address so I was half an hour late. The office was in the center of Hollywood just a few yards from the Capitol Tower. The manager was Shelley Berger, a white man maybe ten years older than me.

Motown was still a company with a strong local Detroit roots. But behind the scenes powerful forces had been set in motion to move the entire company to the West Coast. Already they did some recordings here through their daughter-companies (Gordy, Tamla, Soul, VIP etc.)

Shelley told me about the Motown business. They had about 40 acts contracted, and spent a lot of time choosing clothes, rehearsing stage shows, take pictures, etc. They tried to build 
up and teach an artist so they had a career to fall back on when records stopped selling.

He compared their own efforts with the success Stax had in recent years. He thought Motown was too early with their own package shows. They had first sent out their artists with Dick Clark's Caravan of Stars; mammoth tours with up eighteen acts of different artists. Now the focus was on quality instead, said Shelley. (Motown artists were often criticized for not being able to reproduce the sound of records on stage).

He also said that record labels Atlantic-Atco got the best of the earliest Motown tours and then meant that those companies had released a few compilation LPs from the early concerts.

They had lost a key employee when Mickey Stevenson took his wife, Kim Weston and founded Venture Records. A new artist they had high hopes for was Blinky (from the group Cogics). She lived in Los Angeles as did Barbara Randolph (their only white singer). The Contours had a new lead. Shelley gave me a big chunk of publicity pictures to take with me.

He also confessed that he was very impressed by Ike \& Tina Turner. I could understand that he wanted to engage the pair to the Motown label. He also recommended that I should contact Pat Alexander, a young girl on the public relations department in Detroit, when I got there.

As we talked, a couple of young black songwriting guys arrived. Shelley showed them around the premises and gave them access to a piano to play on. Songwriters were scarce and these boys 
seemed timid and shy, but maybe became a great songwriting team in the future. Gloria was on her way to Venture Records for a studio job as a backup singer.

I was too tired to follow and unfortunately missed Gloria's studio work, but now it was time for another evening with Ike \& Tina Turner. That was important.

Tuesday, August 6

During my walks in Hollywood, I had visited Specialty Records (8300 Santa Monica Blvd). Their office was located in a fairly new, unattractive concrete building. Only Janet Regier, Art Rupes secretary was there, but Art responded promptly to a letter I sent from Detroit. (On the same page in the address book I had written Bob Scherl Prod. A \& R, 1418 N. Highland Ave, LA. He was perhaps affiliated to Specialty?) I continued to make calls to various record companies. There were lots of them in Los Angeles.

Ray Charles Enterprises, 2107 W. Washington Blvd, was also the headquarters for the record company Tangerine that Ray Charles owned. I wrote down the name Joe Adams - I think it was him I spoke briefly with. He was not just Ray Charles' manager but also a disk jockey and he had a prominent role in Carmen Jones, a film directed by Otto Preminger with an all black cast. He had also recited poems on a 78 on Mercury. (I also wrote down the names Lu Washington, Ike \& Tina Turner and Louis Jordan - other performers on the Tangerine label).

Vault 2525 W. 9th - Their most interesting artists were probably 
The Chambers Brothers. They came to Stockholm the following year.

I never managed to get hold of someone in charge at Modern Records (5810 So. Normandie Ave). The distance to them was discouraging when I had a map in front of me, and the heat was oppressive.

I went to an air-conditioned cinema quite close to the hotel and saw a Kurosawa samurai movie (Sanjuro), instead. The cinema was worn down and had many tired patrons looking for rest and sleep in the afternoon.

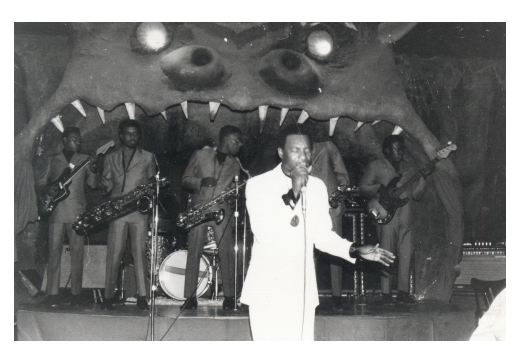

Harvey Scales

Later I went to Hollywood and the Haunted House (6315 Hollywood Blvd). Harvey Scales was there with his orchestra, the Seven Sounds. He was born in Memphis in 1941 but moved to Milwaukee at age nine.

During four years he sang gospel music before joining the $R \& B$ group the Esquires (1958-61). In 1967 this group had hits with "Get On Up” and “And Get Away.” But from the beginning, they were just one of many Frankie Lymon \& The Teenagers clones. They did not record while Harvey was with them. The group's personnel were Gilbert Moorer, Alvis Moorer, Sam Davison and Harvey, who later was succeeded by a new lead singer Mills Evans, whose voice was in the bass-baritone register. In 1961 Harvey started his own backing group - the Seven Sounds. He had retained the same musicians all the time: 
Harvey wrote down the names of his band members and I stick to what he wrote, although he was perhaps slightly dyslexic:

Al Vance (bass), Rudy Jacobs (guitar) Billy Stonewall (drums), Monnie Smith (trumpet), Melvin Taylor (tenor sax), Ben Perty (baritone sax) and Rollo Armstead who did military service at the time and probably played the tenor sax.

Harvey and his seven-piece band backed up and toured with visiting artists in the Milwaukee region like William Bell, Carla Thomas, Wilson Pickett and Pigmeat Markham. On record, the band is very tough, and driving and sounds great but on this night the guitarist in particular made mistakes. I was not that impressed, although Harvey repeatedly emphasized how good they were and asked if I didn't agree. It was a shame that they did not quite measure up this evening.

In 1967 they recorded their first record ("Get Down” / "Loveitis”) on Magic Touch, a Milwaukee company. It sold well and Stax picked up the distribution. The follow up was "Broadway Freeze” / “I Can’t Cry No More,” which was a hit summer 1968. Steve Cropper had said that he was going to produce Harvey Scales and the Seven Sounds. Harvey said their next would be "Love Is A Gas" which he wrote himself and Steve Cropper produced. He also worked on his first album, hoping to leave the dance genre behind. Harvey's own favourites was Otis Redding ( "Otis was a friend") and Wilson Pickett and Sam \& Dave. He had also temporarily joined bands that backed the Motown artists. But that never felt good ...

The Haunted House was not a typical soul club. They were 
usually very simple places without embellishment or design, but this one had been decorated in a haunted house-style. The audience seemed used to rock and psychedelia. Harvey did a good and energetic performance with kneeling and singing without a microphone as he drove through the group's own hits and a bunch of soul classics

“Soul Man,”“Dock Of The Bay” (Harvey told the audience that Otis Reddinghelped them get their first recording), "IGot TheFeeling” (with James Brown dance), “Eleanor Rigby,” “Midnight Mover,” “I’m In Love,"

The band did not sound good on the last two Wilson Pickett numbers, and the guitarist did mistakes on "I'm In Love.”

Wednesday, August 7

I ordered the ticket to San Francisco and gathered my last strength for tonight's show with Ike \& Tina Turner at the California Club West. James Brown had announced his arrival, but he would arrive late at night. I got off the bus on Sunset Strip and first went by PJ's (8151 Santa Monica) where Blossoms were due, but they were delayed. This had been Trini Lopez' headquarter before. Instead, I went to the Ashgrove, which was a famous folk-music club at 8162 Melrose. I had avoided this kind of place so far, and not even been to the Preservation Hall in New Orleans. I was looking for authentic places for black people, and not museums for whites. Magic Sam was booked at the Ashgrove for two weeks. I was shown to the dressing room that lay alongside, and before the public entrance. Magic Sam had one leg in plaster cast and was resting before the evening's 
performance. Present was also his uncle and manager Shakey Jake. The only song I know with Sam was on the English Sue LP We Sing The Blues. Sam knew immediately that it was the Fats Domino song “Every Night About This Time.” I think this was his first tour to the west coast.

Magic Sam was born on February 14, 1937 in Mississippi and moved to Chicago in 1950. He sang spirituals and gospel with the family as second tenor but did not really like it much. He wanted to play guitar and at seven or eight years of age he made his first attempt. His father played guitar and sang the blues at large barbecues arranged outdoor that lasted for five days or longer. The Magic Sam at the Ashgrove organizers made a lot of money selling food and moonshine. No police officers dared venture out into the woods in the middle of the night to a place only lit by torches. There a lot of blues was played and it inspired Sam. At age fourteen, Magic Sam got his first guitar. But his mother died and he was raised by an aunt in Chicago. Sam lived on the south side, and at age seventeen he moved over to the west side. He did nothing but play the guitar and sing. His friends thought he was strange that he never went out and enjoyed himself. 
He sat at home and practiced and listened to records. Sometimes, at lunch hour in a café, he managed to attract the other guests attention and play a few songs. He also entered talent shows, and sat in with various bands as soon as someone let him.

In 1957 when Sam woke up, he had heard a song in a dream and he immediately began to rehearse it. He could not read music. Sam took the song to Chess, but Willie Dixon was also affiliated to the Cobra label and took it there instead. The next day they recorded “All Your Love.” (I also wrote “A Dollar Bill Love.” Was this an alternate title or a different song?)

A few weeks earlier he had walked into a shower of bullets outside a club in Chicago. He had been hit by two bullets. One had had touched the hip and caused a flesh wound while the other went straight into the lower leg bone. It had been plastered after the bullet had been removed. "It hurt so much that I just wanted to cry,” said Sam.

In the room were his two accompanying musicians. A white girl with dirt blond hair, a wan face and flower-power clothes looked through the door and said hello to Sam. She said she was tired of the American thieving society and wanted to move to Africa soon.

It was time for the evening's first set. The interview had to stop while Sam got ready.

I then exchanged a few words with Shakey Jake. He toured Europe with the Folk Blues Festival in 1962, but worked as a manager now. He did not play with Sam, but wanted to put on a 
show of his own when he was not making a living as a gambler. Shakey Jake got his nickname from his time as a dice player but his handwriting was also quite shaky.

He gave me the address of Sam's record label and I believed that Magic Sam recorded for "Bob Easties” on "Dead more Records” in Chicago. While Shakey meant Bob Koester and Delmark Records ...

I was torn between staying or going and check out James Brown and Ike \& Tina. Sam solved the conflict by resolutely taking me under my arm past the ticket booth into the room which was just over half full. (Admission cost \$2.)

His performance was impressive and powerful. The two numbers I could identify were Out Of Bad Luck and I Feel So Good which was another version of John Lee Hooker's "Boogie Chillum.” I had not yet heard the LP Sam recorded the year before in Chicago with Per "Stockholm Slim" Notini on the piano. (Stockholm Slim was also offered an engagement as sideman in Howlin' Wolf's backing group.)

After the final chord we parted. In the hall I had met Ken Courtney from Playa del Rey in California. He called himself a blues expert, perhaps self-appointed, but he was actually the only white music “expert” I met that summer.

I rushed back to the Ike \& Tina Turner Show. Nowadays Ike had arranged that I was let in for free. But James Brown had not appeared, and he never came. The show was still unforgettable as usual. I then hitchhiked back with a Hells-angel-like beatnik 
in a beat-up wreck. He had recently crashed and waited for the insurance money for a broken leg. Then he would go up to Portland where there was a lot of cheap drugs and where people were relaxed. Unless he got so much money that he could afford to go to Greece. There were also good times.

Thursday, August 8

I rose at 9:30 am to catch the plane that left at 11:35 to San Francisco. It had been a very trying time in Los Angeles. I had not had time to do but a small fraction of all I wanted to. I was thoroughly tired and had sore feet after all the walking and waiting for buses. My interviews in Los Angeles contained more "maybe" and "probably" than usual because I was simply too tired to grasp what was being said or repeat the question. Ike \& Tina and Magic Sam followed me to San Francisco. They were on West Coast tours.

Radio listening was neglected. I didn't have time to spend many hours in the hotel room. But some new songs were heard and my favourites are marked with $(*)$ :

Bennie Conn- “I’m So Happy To Be Back Home”

(*), Junior Parker- “Like A Fish,” Jesse James- "Fast Women,” Ike \& Tina Turner-“Understanding” (*), Ed Townsend-“For Your Love” (*), James \& Bobby Purify“Help Yourself,” Roy Brown-“Double HBlues,” Larry \& Johnny Guitar Watson-“Nobody,” Roy Brown"Separation Blues," William Bell \& Judy Clay - "Private Number,” O’Jays - “Look Over Your Shoulder,” Albert Washington-“Bring It Up” (*), Skyliners - "Since I Don’t Have You” (*), Sweet Inspirations - "Unchained Melody” 
(*), Jay Lewis-“Moonie Moonie.”

Al Wilson - "The Snake" (Soul City Records) was also played frequently. It was a fine Oscar Brown Jr. inspired number. I got publicity materials and an answer from Al Wilson and his manager Marc Gordon. Al had another soul hit with Searching For The Dolphins at the same time. (Soul City Records, 8923 Sunset. and Marc Gordon worked at 8350 Santa Monica Blvd, Suite 108. I think Willie Hutch came to Soul City Records later. There was also a club or studio called Soul City at 6920 W. Sunset.

\section{Postscript}

In 2003 the gospel star Andrae Crouch came to Sweden. He had been in the COJICs super gospel group with Billy Preston and Gloria Jones. I contacted him after a performance at the Filadelphia Church at Rörstrandsgatan and showed him my photos.

Andrae was tired after a stroke that same year, but after a while he exclaimed, "Gloria !!! - But I met her a few weeks ago! She was in Los Angeles at her father's funeral. Last year her mother died. Gloria lives in South Africa now."

A few years ago I read in a book written by an English spiritualist medium that Gloria belonged to her clients and was in contact with her late husband Marc Bolan. Gloria was a good singer, but there were quite a few gospel trained singers that sounded like her. She's now called the queen of Northern Soul (The type of old soul music still highly popular as dance music 
in the north of England). But a softer voice like for example that of Doris Troy, Betty Everett or Shirley (of the Shirelles) might have given her more hits.

Ike \& Tina Turner performed across the United States and had been in Europe. Behind Ike \& Tina's current show was the experience of thousands of gigs in endless one-nighter tours and lots of recordings.

Ike managed to turn an evening of entertainment and relaxation for an adult audience to an unforgettable artistic experience at the highest level - a level that an audience in Sweden could only dream of.

I also believe that Ike very consciously was working on getting a larger white audience. The entire English rock elite had seen Ike \& Tina Turner when the Rolling Stones had booked them as an opening act. He must have noticed that many whites (Europeans) lit on all cylinders when they saw Tina.

Ike embodies one of the male archetypes in the AfricanAmerican community: the pimp. He chose to launch Tina for the white audience, as if she was working in the sex industry. Ike, who had never been known for his good taste, created a vulgar stage show around Tina and the Ikettes. But Tina was able to soften this image with humour and self irony.

Ike probably got many new insights during the English tours in 1967. Perhaps he was invited by Brian Jones and Keith Richards to long nocturnal conversations. Maybe Ike understood that these boys, who seemed to have an unlimited supply of money, 
would have given Elmore James one Cadillac each for a guitar lesson. Perhaps Ike previously had thought that Elmore was a hopeless drunkard. They met when Ike was working as a talent scout for the Bihari brothers. Then Elmore could not even remember the lyrics when he recorded his fabulous Canton Mississippi Breakdown.

Tina, however, pregnant or not, was a real workhorse who never betrayed him and always did as he said. In her he had found a gold nugget. She taught Mick Jagger how to move on stage and made friends with the entire English pop elite.

Milos Forman, in his first American film (Taking Off - 1971), showed white, middle-Americans in search of their runaway children in hippie America. Meanwhile their parents tried hashish smoking, wife swapping and of course black soul when Ike and Tina Turner sang “Goodbye So Long.” Ike \& Tina were also with the Rolling Stones at the Altamont Speedway (1969) and in the documentary film Gimme Shelter. But I no longer recognized her. Tina has said that Ike hit her so much on the nose that she got sinus problems and excess cartilage formation. When this was corrected she also got a new nose. She looked like a Thai barmaid and no longer like a native American on the warpath.

Shelley Berger at Motown West never said that his main job was as manager of The Temptations. He later had a fairly prominent role in the two-part TV-movie about The Temptations shown on cable television. (He financed the film.) They were the most popular male group then but went through a difficult period. Their amazing lead singer David Ruffin was about to be fired 
because of bad behaviour and abuse. Maybe Shelley didn't want to talk about it.

Venture Records was soon bankrupt. I guess they expanded too quickly.

The LP with Jimmy and Vella did not sell. It became a cut out/ overstock album selling for fifty cents.

Larry Williams committed one of the more mysterious suicides in the 1970s when he managed to shoot himself in the head five or six times ... Today the suicide theory has been abandoned. Session guitarist Chuck Norris said that Larry had a cocaine habit that cost him $\$ 4000$ per day ... It was an abrupt and tragic end for the philosophical Larry, who said: "Rock \& Roll has no beginning and no end for it is the very pulse of life itself.”

Later I understood that Roy Brown was a true pioneer and the first popular $R \& B$ artist to record in a singing style taken straight out of the church and gospel. He influenced a whole new generation of singers. When Jackie Wilson's Lonely Teardrops hit the charts in 1958, people congratulated Roy. They could not hear any difference between Roy and Jackie.

James Brown has said that Roy was his biggest inspiration in his teens. B.B. King, Bobby Bland and even Fats Domino tried to sing like Roy when they started their careers.

There were many record labels in Los Angeles, I had no time to visit or call the following:

Capitol (1750 N. Vine) was still located in its round tower. 
$382 \cdot$ JONAS BERNHOLM

Double Shot (6515 Sunset Blvd)

Duo Disc (8831 Sunset Blvd)

Everest (No. 1313 Vine St., Hollywood)

Original Sound (7120 Sunset Blvd, Hollywood).

Sureshot (8255 Sunset Blvd)

Paramount Recording Studio (6245 Santa Monica)

I never met Dyke and the Blazers who made the original "Funky Broadway" (1967). That song was still on everyone's repertoire. Rendez-vous (with entertainer Googie Rene). And someone recommended to see Viola Wills (an artist with roots back to the 40-s). She performed at La Rue between 9:00 pm and 2:00 am. 


\section{San Francisco}

August 8 - 14, 1968

Thursday, August 8

The hotel room on Turk Street smelled strongly of old cigars and I took a long walk and got acquainted with the city. On the way I passed the club in the North Beach district where Carol Doda was working as a waitress. She was a silicone pioneer and much talked about in the US at the time. Rumour said that she carried the drinks on her breasts instead of on a tray. Ten years later, her name was still up outside the club, but in smaller letters. In this neighbourhood Jack Kerouac's heroes partied and listened to bop music in On The Road. The "Summer of Love" in 1967 was a short high point of the hippie era in San Francisco. A year later, confused and drug-using people of my own age were still there.

A Samurai Film Festival opened in Chinatown - Admission cost $\$ 2$. 
Friday, August 9

In the morning I went to radio station KSOL (150 8th Street). Program Director was Tom Johnson and I talked to one of the station's six disc jockeys, and also its friendliest - Bert Bell. In San Francisco $10 \%$ of the population was Mexican and $10 \%$ was black, while $85 \%$ of KSOL's listeners were black. They had 45 songs on the playlist. And three times per hour businesses and nonprofit organizations in the black community advertised for free. Circa twenty different activities every week were presented for listeners by the people involved. On Sundays they played gospel music for five hours.

Famous San Francisco artists were the Ballads, Joe Simon (who was on tour), the Magicians, Fred Hughes and Little Johnny Taylor. But the most famous one was still Sly \& The Family Stone and Sly had worked as a DJ at this very station. KSOLs main competition was KDIA in Oakland with Buggs Scruggs as their most famous DJ.

I got some information about local clubs and venues. Mostly in San Francisco, but also in Oakland and Richmond:

Avalon Ballroom (1268 Sutter)

The Carousel Ballroom (at Market and Van Ness Ave)

The Coliseum (which was a large arena in Oakland)

The Cow Palace (Geneva Ave)

Fillmore Auditorium (1805 Geary)

Long Island Club (3rd St.)

Masonic Temple

McKesmo Club in Richmond 
Mr. D’s

Showcase

The Winterland (At Post/Steiner)

There were two Sportsman clubs. One was at 1414 Turk in San Francisco and the other at 5319 Grove in Oakland.

Someone suggested that I should visit the newly established music magazine Rolling Stone at 746 Brannan. The editor Jann Wenner was the right man to see there. I also noted down a few addresses which I do not remember what they were about: 325 Mason Boxoffice (maybe that's where I bought tickets for James Brown show), and Du Base Stephens, 1925 East 19th St.

The entertainment pages showed that Magic Sam was opening for an English band (either the Who or Ten Years After). They were at the Avalon Ballroom or the Fillmore during the weekend. This concert was only announced as a small ad (onetwo lines). But I had seen both groups the year before, and there were much better artists around.

James Brown, Ray Charles, Ike \& Tina Turner were in town and the radio announced a concert by Jackie Wilson in San José, or in the area later known as Silicon Valley. Jackie was there on Sunday, at the same time as the James Brown show. I could choose between the top three of the most popular R\&B artists of the last fifteen years and the best female stage performer of that era too ... (Even if the show in 1967 with Ten Years After was the best I've seen with an English group, they were playing in a much lower division than these American artists.) 
Saturday, August 10

In the evening I went to Mr. Ds, in the center of San Francisco, to see Ray Charles. Admission (\$4.50) included food and drink before the show and that was too expensive ... I stood strategically at the stage door to get in for free instead. It did not take long to see Billy Preston's face appear under a street lamp in the dark. He understood exactly what I wanted and got me in through the back door. He spoke with the staff so I got a seat at the long dinner tables too.

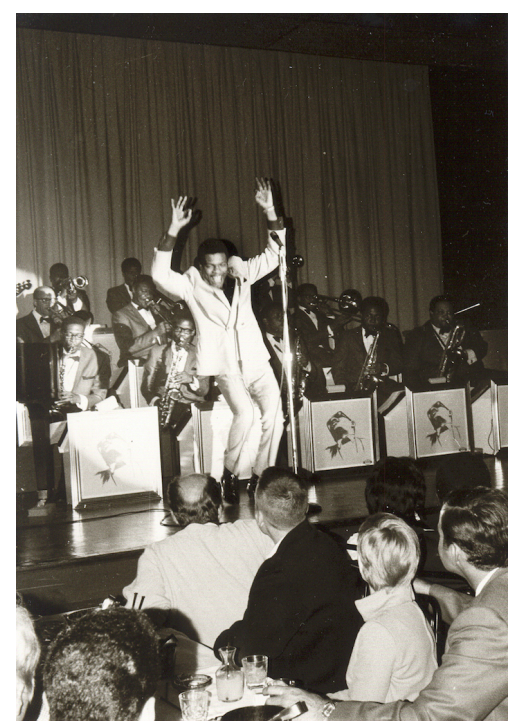

Billy Preston with the Ray Charles Orchestra
Billy Preston was known to the Swedish audience. His instrumental version of In The Midnight Hour was used as the theme song of a popular radio program broadcasted on Saturday night. His LP "Wildest Organ In Town” (Capitol) was found in well-stocked record stores.

William Preston was born September 2, 1946 in Houston, but he moved to Los Angeles before he was one year old. His father stayed in Houston, “and that's how long I had a father,” said Billy laconically. Billy’s mother played the piano in church and already at the age of three Billy learned to play. In 1955 Billy got a role in the film St. Louis Blues, about 
W.C. Handy's life. Nat King Cole played the title role, and Billy was W.C.Handy as a boy. Later Billy met Nat on a TV show and he promised that he would arrange a recording contract with Capitol for Billy. But Nat, always friendly and helpful, died before it became a reality.

Billy preferred the organ, but he could only practice in church. When he was eleven, he got an organ of his own. Only fourteen years old, he became a member of the group Cogics, which consisted of young members of the Church of God in Christ. He sang and played organ with the singers Gloria Jones and Sandra "Blinky" Williams and the twins Sondra and Andrae Crouch.

Cogics was the best young gospel group in Los Angeles and recorded on Vee-Jay. (See the part about Gloria Jones in the Los Angeles section.) Billy also recorded a solo LP on VeeJay called "Hymns Speak From The Organ.” But soon VeeJay folded as did any possible payment. Already in 1962 did Billy record the solo record Greasy for Sam Cooke's SAR label. Despite the title, it was a "semi-gospel” recording, explained Billy. Billy also played the organ at James Cleveland's How Great Thou Art which sold nearly a million copies. Billy was then sixteen years old and a fully fledged gospel artist. He had no intentions of becoming pop artist. But that border he would soon cross.

Little Richard had dramatically left show business in the late 1950s and in 1962 he planned a gospel tour in Europe. He chose Billy as his organist. Sam Cooke, a former member of The Soul Stirrers would join. During the boat trip to England Reverend Richard Penniman preached and sang for the fellow 
passengers. But when Richard saw Sam Cooke, who had the first part of the concert, tear down the house, he knew that it would a fiasco unless he sang his rock and roll hits. Richard quickly changed the program. First he sang “I Believe,” a pop song with a religious theme, and the rest was pure rock and roll. But between the performances Richard arranged Bible studies with the Beatles and The Sounds Incorporated, the accompanying orchestra.

The performers also came to the Star Club in Hamburg. Billy loved every second of the tour and felt like a rock and roll organist after six weeks. He got a lot of new friends. Not only with the Beatles, the opening act, but even more among the Sounds Inc.

It was a high-speed musical adventure. I had seen the Beatles live the following year in England (1963) so I understood what he was talking about. But Richard was not happy. He did not want to sing rock \& roll, and he did not like to see Billy dress inappropriately and be out all night. Richard left the tour but unfortunately took Billy's return ticket with him. So Billy had to stay longer than planned in England.

Billy had not really listened to or been aware of any other music than gospel when he was growing up. The only exception was Ray Charles, and Billy had bought all his records. With friends he formed a group called the Bill-ettes, that only sang Ray Charles songs. He also used to dedicate fifteen minutes every day to Ray and sometimes he pretended that he was blind. He was then escorted to a restaurant and helped to order and eat. 
Ray also lived in Los Angeles and when Billy was around ten years old, he managed to gather enough courage to call on his door. Ray was singing at the piano and Billy said that he loved his music; he had all the records and a group that only sang his songs. But Ray responded that he was not in search of a new Ray Charles! Later, they met at a Shindig TV show when Billy was his stand-in at the rehearsals. He knew exactly how Ray sang and moved, and many who didn't look carefully, thought it was Ray who sat there.

In 1965, Billy got a contract with Capitol and his first LP Wildest Organ Ever was arranged by Sly (of The Family Stone). But the producer did not understand $R \& B$ and he had too little opportunity to play as he wanted. The result was not very successful, said Billy. In addition to Billy's Bag and a couple of his own compositions, he had to record other artists' songs. He was not pleased with Wildest Organ In Town either, and finally managed to stop the release of a live LP for Capitol.

Now, he produced his own records and was hoping for a better result. Still “In The Midnight Hour” had been a big hit.

Behind the stage, I ran into Jessie and Joe, two members of the Soul Brothers, a group who sang with Billy in 1962-63 and they recorded an LP on Vee-Jay as Billy Preston \& The Soul Brothers, which was never released.

Then they came to Capitol and made an LP called "Operation Cool Head.” They were Joe Green (born September 29, 1946 in Los Angeles), Douglas Gibbs and Jesse Kirkland (born June 10, 1945 in Ohio). They said they were the first to use the name 
Soul Brothers but there were a lot of problems and Douglas left the group. As the duo Jessie \& Joe hey had recently been signed to Columbia, while the discs were released on Epic. Now they planned to do a sophisticated show with standard songs for the night clubs. They had also performed together with Blinky. (This was told by Joe Green.)

It was a full house that night. The audience had finished their dinner, and Billy had gotten a seat and a free beer for me. Ray Charles big band started playing, showcasing the many great jazz musicians who were in the orchestra. Then Billy did Agent 00 Soul, Edwin Starr's soul hit. Billy danced around on stage and demonstrated the latest dance fashions and a James Brown inspired footwork.

Billy also did the Rolling Stones' "Satisfaction" standing at the organ. He showed what a champion of organ playing he was. After this brief introduction it was time for Ray Charles. He did a fine show, intended for a seated, white, middle-class audience, with R\&B, Country and Western and jazz standards done in the Ray Charles way.

“Something’s Wrong With My Baby,” Instrumental, “Georgia On My Mind," "Yesterday," "Premium Stuff," "Crying Time,” “Tell The World About It(or You),” “Eleanor Rigby,” “Understanding,” “What’d ISay.” 
I missed "I Don't Need No Doctor," which I think is his very best soul number.

Ray Charles, also introduced Billy during his own set, with the following words:

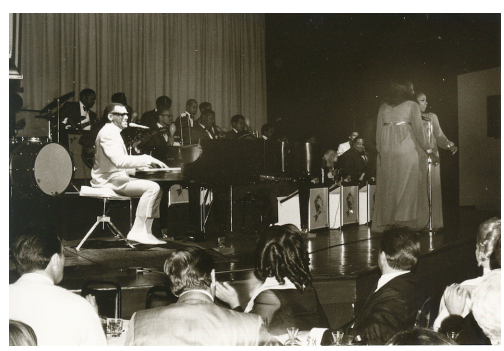

Ray Charles in Hollywood

"When my career is over and

I have to step down from the stage it's comforting to know that there is a very talented young man who can do what I've been trying to do all my life. Here he is: Billy Preston!"

Ray was in great spirits. He interrupted the show and started to talk and did so incessantly for at least a quarter of an hour. He also did a short opera-segment - thus satisfying probably every taste in the audience. When the show drew to a close, he did not want to leave the piano.

Ray Charles has been called the best gospel-based singer who has never sung gospel music (professionally). Otherwise, he could have led his own "Five Blind Boys of Georgia (or Florida)," and given the blind groups from Alabama or Mississippi a tough competition in many exciting "battle of the groups.”

But it was probably quite foreign for Ray to accept the life offered to a blind singer then. Instead he first followed in the footsteps of Charles Brown and Nat King Cole before singing gospel influenced R\&B. Still always in control unlike soulsingers like (the early) James Brown or Wilson Pickett. 
When Ray was in Stockholm the following year he had Mable John, Little Willie's older sister, in the Raelettes. She had recorded on both Stax and Motown, and sang a fine soul version of “Same Time Same Place.” But I do not think she was here this night.

There were two dinner sittings and two shows that night and I saw both. Ray had been the most popular black artist before James Brown, but pretty soon he had a large white audience and was launched as an overall musical (jazz) genius. But his show lacked the nerve and precision many black artists had when they appeared before a black audience. Ray had relaxed after many years with white audiences.

Billy suggested we see Ike \& Tina Turner together the next day. He had a little free time before tomorrow's show and the pair appeared very near Mr D's. I could hear the Kings of Rhythm play when I entered the street on my way home. But this Sunday it was James Brown time for me.

I understand why many English musicians had taken Billy to their hearts ever since 1962. He was a very nice guy.

\section{Sunday, August 11}

James Brown appeared seven days a week all year round. We had been in Atlanta, Miami and Los Angeles almost simultaneously but I had missed his show by a day or two. Now San Francisco was full of posters advertising "A show for the entire family."

So far, my trip has been largely exempt from racial tension, 
although the mood in Los Angeles had been worse than in other towns. But after the assassination of Martin Luther King, radical, militant black political groups came to the forefront with the Black Panthers in the lead.

James Brown was the most popular black artist in all categories and endorsed Democrat Hubert Humphrey in the presidential election which Richard Nixon won in the autumn of 1968. James had released the disc “America Is My Home” a few months earlier. On this prehistoric rap recording, James supports the American dream - where everyone who wants a better life can create it for himself and his family.

James Brown:

But name me any other country

You can start out as a shoeshine boy

And shake hands with the president

It ain't gonna help you gotta have that royal blood to make it And I ain't got nothing royal but me

So I can take the chances, I'm gonna stay home

And look ahere I got a brand new jet

When I need to move

I saw a brother made it

Now ain't that a rule

James Brown's black capitalism probably had more support among future Reagan economists than in the Black Panther Party where these views were considered reactionary. James Brown was sometimes threatened by militant black groups 
during his concerts. The situation in San Francisco-Oakland was extra polarized. The Black Panthers were formed in Oakland. Their leader Huey Newton was imprisoned. Outside the town hall in San Francisco militant black groups demonstrated around the clock. "Free Huey!” was heard everywhere.

But James Brown had taken note of the criticism of "America is My Home," and had just recorded his new single "Say It Loud I'm Black And I'm Proud," which became the signature tune for militant blacks.

The concert hall (the Town Hall or the City Auditorium) the name of which I forgot, held a few thousand listeners, but was not more than half full. But there were many guards.

During the intermission I went to the foyer. Suddenly a big brick or stone crushed one of the windows and we ran back into the safety of the concert hall. I was convinced that it was not the Ku Klux Klan or an Aryan power group that threw these stones. This was an internal fight between blacks, perhaps fired up by FBI infiltration. (The Ku Klux Klan were behind several bombings that summer and the FBI had infiltrated them.) The most popular artists were asked or blackmailed for financial support. Did James refuse to pay his part to the Panthers?

The mood among my bench neighbours was cold too. It was hard to get them to cooperate when I tried to get out to take photographs.

I was not included in this family show.

Showtime! 
First the James Brown Orchestra played a few instrumentals before it was time for the local black group - The Mystics. They were five men and first made a falsetto version of "I Heard It Through The Grapevine” and then "I'm Losing You."

And finally a section called "Dance Beat," where they demonstrated that they were good dancers.

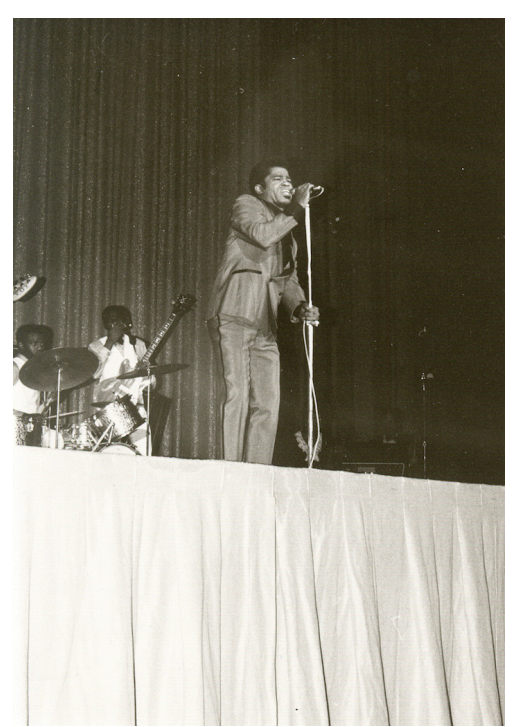

James Brown

Then James Brown entered the stage for the first time. He was introduced by a woman. He began to warm up the audience with a pop song: "If I Ruled The World" and then "Say It Loud I'm Black And I'm Proud," where the crowd stood up and chanted the slogans. (I'm not sure it had been played on the radio yet.)

“That's Life” (Frank

Sinatra's signature), and finally “Kansas City,” and James danced off the stage

Then Marva Whitney, a protégé of James Brown, was introduced. He produced her records. She looked very young, skinny and vulnerable, and she sang “Ain’t No Way” (Aretha Franklin) and “Here I Am Baby” (which didn’t sound too good).

Then James came back. He was introduced by another black 
man (probably a politician), like a real Soul Brother. James emphasized that he had never forgotten where he came from and what had brought him here. Now, James performed some of his best soul ballads: “Lost Someone,” “It’s A Man’s, Man’s, Man’s World,” "Bewildered," "Cry Cry Cry.”

James Brown's melodramatic performances are always unsurpassed. These songs are truly great, but he had sped up the songs a little bit and done other unnecessary tempo changes. I was not completely satisfied. The lights were turned out and James disappeared again.

It was time for another further short set from Marva Whitney: "Natural Woman"

(Aretha

Franklin), "People” (Barbra Streisand).

Then the James Brown that the audience had come to see appeared. He did several blockbuster, funky dance hits from recent years:

“Cold Sweat,” “Lickin' Stick,”“I Got The Feelin',“'I Can’t Stand Myself," "Maybe The Last Time," and he did "Please Please Please" for the first time.

This was only a short version to remind the audience that the show was coming to an end. The audience reaction enabled him to make a few extra numbers in a row - his best early funk numbers (alongside "Out of Sight” and "Night Train”) namely, "Papa’s Got A Brand New Bag," "I Got You.”

Then followed "Please Please Please" with the classic ending where his aide dressed him in a robe (or boxing champion cloak) 
and tried to lead out the totally exhausted singer. James threw off the cloak twice and then returned while the orchestra played the riffs. Now the audience really reacted. Some ran toward the stage where helmet-wearing staff were guarding. A couple of bottles were thrown, but no one was hurt.

James Brown had the deserved reputation of being America's greatest (black) stage performer of all time and all categories. I would not protest if someone suggested that this covers the entire twentieth century.

But there were cracks in the facade. Much of the voice was still there even though he often was quite hoarse and hardly could do "Shout And Shimmy" any longer. He had gained weight and his footwork was slower. The moves and steps were often hinted at and not taken out completely. He had met his audience so often that he hardly needed to prove or accomplish anything anymore.

He could still move across the stage on one leg, spin around a few times, do the splits and grab the microphone without missing a beat. His dramatic vocal style with the right song selection was second to none.

But the weaknesses I had seen in Stockholm the previous year were more pronounced now.

In 1967, he had only two background singers left (including Bobby Byrd), but they sang very little and danced mostly.

Now the Famous Flames and their gospel quartet-sound had disappeared and he had only one go-go girl left. It felt cheap. 
The repertoire was more funk-based and Tina Turner did a (much) better version of "Please Please Please" - the song that finished all his shows since twelve years back. James didn't plead or said "please" to anybody. He took what he wanted. It didn’t fit his personality to fall on his knees.

His performance was narcissistic and James Brown asked himself not to leave the stage and gave the audience the opportunity to ask him the same ( "Please, do not go!"). But for Tina Turner "Please Please Please" was the perfect expression of the feelings she was carrying.

The show lacked fluency and did not build up to a natural climax. The famous very long Apollo Theatre introduction from 1962 when James Brown is presented before he enters the stage was also removed. It exemplified the grandiose and extravagant atmosphere that existed in soul music when it was at its best. The inspiration probably came from the church but the names of God and Jesus had been changed to James Brown. ( "The man who walked on water! - The man who raised the dead!” etc).

Expectations were built up to maximum and then James entered and surpassed it. (Bill Clinton used this presentation in his first presidential campaign, and he got all the black votes.)

It was strange that James introduced his latest hit "Say It Loud I'm Black and I'm Proud” so early in the evening. Did they want to silence any demonstrations?

My own favourites in James Brown's repertoire are the pure gospel-based songs like “Oh Baby Don’t You Weep,” “Maybe 
The Last Time," “Shout And Shimmy," etc. Or soul ballads like “It’s A Man's Man's World.” But now his hits sounded like a marathon funk dance party where songs like "Lickin' Stick," “There Was A Time," "I Got The Feeling” were succeeded by another sounding the same. And the pace of many older songs were sped up.

James Brown was moving in a direction that I did not think was musically satisfying. White people were no longer welcomed by his black fans. Songs like "Say It Loud I'm Black and I'm Proud" accelerated this trend.

I moved backstage after the show, and after a while I came to the orchestra's dressing room. These musicians were in his band:

Waymon Reed (trumpet) was born January 10, 1940 in Nashville. He had been with James for three years and also played on Steve Alaimo's LPs. Next to his name, I had written "nice.” Because it was he who took care of me and made sure I got to James Brown's dressing room later.

Richard “Kush” Griffith (trumpet) was born August 8, 1948 in Louisville, Kentucky. He wrote down a short presentation about his life with James Brown, “joined on the 18th May 1968 as a result of a recommendation of a good friend (my father)." Richard was rather corpulent.

Levi Rasberry (trombone) was born in Washington, August 5, 1946 and he had been with James Brown since late July 1964. He was small in stature.

Fred Wesley Jr. (trombone) was born in Mobile, Alabama, July 
4, 1943. He had come to James seven months ago. He had also played with Ike \& Tina Turner.

St. Clair Pinckney (Baritone and tenor sax) was born September 17, 1930 in Augusta, Georgia. He had been with James for six and half years. Before that he was in and out of the military for five years. He and James were school friends during two and a half years. He had a white cap on his head.

Maceo Parker (tenor sax) had been with James since one and a half years but also earlier, and then had left and come back.

Alfred Ellis (soprano sax, organ) was born April 21, 1941 in Leesbury, Florida. He had been with James for two and a half years. Before that, he played jazz organ in Jimmy Smith inspired trios.

Jimmy Nolan (guitar) had been with James four years. (He looked like Otis Rush). He spelled his name with an a - and not “Nolen”)

Charles Sherrell (bass) was born in March 1943 in Nashville. He had been with James for 2-3 months, and previously worked at Capitol as a studio musician and recorded two vocal discs (on Capitol) that did not sell.

Al Kellum (bass) had been with James for three years. He was good looking.

Clyde Stubblefield (drums) was born in Chattanooga, Tenn. April 18, 1943 and had been with James for three years. (I think he had played with John Lee Hooker before.) 
Nathanael Jones (drums) had been with James for six months.

Richard Jones (violin) was born July 2, 1926 in Brooklyn, New York. He had been with James Brown two and a half years and previously played in various symphony orchestras.

Sylvia Medford (violin) was born in New York but did not state her age and had been with James for a year. I think she was about as old as Richard Jones.

There were fifteen musicians on stage. In their dressing room, I spoke with fourteen of those. Who did I miss? (James Brown did a live recording in Dallas, August 18, 1968. It was the same band members plus Marilyn Jones (violin). But I only saw two violinists on stage ...)

The musicians were a little better paid than in other soul bands. James no longer had much contact with his band members. He, his wife and his 14-year-old son flew between gigs, while the orchestra used the bus. James had done away with the vocal group The Famous Flames about four months ago. Thus cutting away his gospel roots and the early inspiration of the 5 Royales. Around the same time Vicky Anderson left and married Bobby Byrd, the founder of the Famous Flames.

Bobby Byrd had done fine solo stuff (“Funky Soul,” 1967), and I felt that Vicki Anderson was a better singer than Marva Whitney. Bobby and Vicky were really sweet when I stood waiting for James Brown to leave the Konserthuset in Stockholm 1967. (I think I was the only one waiting.) They gave me a James Brown picture. 
James Brown was known never to book other artists on his show that received lots of applause or attracted the interest of the audience. The other artists this evening had been mediocre. Artists had told me how they were fired from his show or that their part was cut short if the audience liked them too much.

Now we were about 30-40 persons patiently waiting outside his dressing room. I had received half a promise to meet him. Through the closed door of his dressing room came instrumental funk music with the James Brown Orchestra. I assumed he listened to instrumental tracks he wanted to develop further or use. Sometimes his voice was heard to comment and at some point he cursed and yelled. A couple of people were let in through the door including his son Teddy, who later died in a car accident. Finally, two hours after the show ended, the door opened. There he was standing a few meters in front of me, with his hair in perfect trim, rather short in stature and wearing a waist-long light brown suede jacket. Then all hell broke loose. I took a step forward, but all others rushed screaming towards James Brown. A girl who stood next to me managed to get her head under the shoulder strap of my bag. It was torn off and disappeared in the turmoil.

His aides quickly pulled and pushed James towards the exit and waiting car. He was gone, and I stood there without a bag.

But I was quickly surrounded by a gang of aggressive black youths. They had taken care of the bag and now wanted money to return it. We were standing on the side street outside the stage door. The street was only sparsely lit. 
These youngsters didn't seem nice at all when they looked me straight in the face and juggled my bag between them. Had they thrown those stones and broken the windows earlier?

I understood that I was in the wrong place at the wrong time. But after much negotiation and an occasional harsh word, I managed, however, to get the bag back. It was empty, and a few small things and the James Brown-concert program was gone of course.

At the same time a car rolled up beside me. A black couple sat inside and they told me to jump in. The man had worked as a janitor at the concert and he saw that I was in danger. My guardian angels had saved me this evening too. But it was probably the most dangerous incident that summer - which now had become both long and hot.

Five years ago, James Brown had been the best black stage artist of his generation (and what a generation it was!) Mick and Keith of the Rolling Stones said after their first US tour and a concert by James Brown that one could place James Brown on one side of the stage and Jerry Lee Lewis, Little Richard and Chuck Berry on the other side. Nobody will notice them because James Brown will get all the attention.

Fifty percent of Mick Jagger's stage show then was of course stolen from James Brown. (And one hundred percent of Michael Jackson's.) No wonder the Stones declined an offer to tour with James Brown at the same time. Dan Penn told me that James Brown had a half-hour standing ovation after his TAMI show. The Stones were at the same show. Everybody could see how 
pale they were in comparison. I joined James Brown's English fan club immediately. I was the first (and only?) Swedish member.

Michael Jackson used to watch James Brown's TAMI film for hours. He remarked that James didn't dance but flew.

Honestly, today I regret that I did not see Jackie Wilson instead. But it was a long way to San Jose, and who could imagine Jackie would be (almost) brain dead after a heart attack on stage a few years later?

I had talked with Bert Bell KSOL about Jackie Wilson. I knew he was a good performer but I was worried that he had difficulty moving due to a bullet fired by a jealous girlfriend, which sat near the spine. Jackie was quite OK, Bert Bell said, but his days as a top draw was over.

Later I also understood why James had not visited the Ike \& Tina Turner Show in Los Angeles. He had recorded “Say It Loud I'm Black and I'm Proud” that night.

Monday, August 12

Yesterday's concert had given much food for thought. It was supposed to be the highlight of the trip but had after all been a disappointment. I had taken in so much musical impressions in a week with, among others Ike \& Tina, Ray Charles and James Brown that there was no room for more. I bought some records and found Malcolm X's memoirs in a bookstore that I began to read at night. I also visited the Swedish Consulate in San Francisco and studied Swedish newspapers. 
Tuesday, August 13

I called the Galaxy record company (1281, 30th Street, Oakland). There Little Johnny Taylor had recorded his classic "Part Time Love.” On the same green label, Roger Collins, had done the original of Wilson Pickett "She’s Looking Good.” But nothing happened there. Charles Brown's “I’m Gonna Push On” on Galaxy was outside the soul genre and I had not heard enough of Charles to understand what a great artist he was. I bought more 45s instead and found Urban Blues by Charles Keil in a used bookstore. I sat atop Telegraph Hill overlooking the Golden Gate Bridge, and continued reading Malcolm X’s autobiography.

Wednesday, August 14

I took the flight to Detroit and arrived at 8:15 in the evening.

James Brown is probably the most important African-American popular music artist of the last century. He was not only a black Elvis Presley, with the same appeal to his audience as Elvis, but he was also the Colonel, Elvis legendary manager.

James Brown said that he was ten-percent artist and ninetypercent businessman. In short, he was Elvis and the Colonel in the same person. While Elvis was one head higher and totally superior to his contemporary white colleagues, James Brown's colleagues were sometimes almost as good, but never better.

They lacked his manic energy and pathological ambition and his ability to always wager one hundred percent. Everybody agreed that James was the greatest male soul artist - Soul Brother No.

1. But he was not at all popular among his colleagues. 
With an enormous ego he stepped on many toes. He could not be trusted. Solomon Burke and Joe Tex openly said that they didn't like him.

It is difficult to compare James Brown's career with other artists. One should rather broaden the comparison to leading politicians and military officers. James Brown worked as hard to totally dominate the black record industry as a Joseph Stalin would have done. His attempt to overflow the market with James Brown records can probably only be compared with Mao Tse Tung's marketing of his own Little Red Book.

He probably used as many dirty tricks as these political heavyweights. James also had political ambitions. He was involved in Lyndon Johnson's Stay In School program and he was the chairman of an association that aimed to keep children in school and he recorded “Don't Be A Drop-out.” When Martin Luther King was shot the mayor of Boston gave James Brown and his orchestra unlimited television TV time to keep young people at home.

The white establishment had begun to understand that James Brown's power and prestige in the black ghetto was unique, that he had a position that no other black artist had. This summer you could sometimes hear him on the radio in a brief speaking part of the need to stay in school and get an education and not to be out and fight. He summed up his message with the words: "Do not burn - learn!” He also owned his own radio stations.

Other artists like Elvis and the Beatles had also totally dominated the industry for some time. Then all old recordings 
and B-sides went up the charts. In 1956 and 1964 all their records charted. Lots of singles were released. (Elvis had $17 \mathrm{~A}$ and $B$ sides of his 11 singles listed in 1956. The Beatles had 30 A and B-sides charted of a total of 19 singles in 1964.)

These successes left James Brown no peace. But he did it differently. The more popular he became, the more discs he recorded and released. Aretha Franklin broke through with a bang in 1967, and in 1968, she had eight records on the Hot 100. But she only released four records (both the A and B sides went into the charts). James Brown also had eight songs on the charts in 1968 but on eight different singles. The year after he had nine songs on the Billboard Hot 100 - and these were from nine different singles. Every trend, and success he milked a maximum out of.

1969: The launch and success of the dance and the song "The Popcorn” was followed by (1) "Mother Popcorn (part 1)” (2) “Lowdown Popcorn” (3) "Let a Man Come In And Do The Popcorn (part 1)” (4) "Let a Man Come in and Do the Popcorn (part 2)" - There were three sequels and a sequel to the sequel ... and all went entered the Hot 100.

My subjective impression is that at least every tenth song on the radio, jukebox or concert gig that summer was with or was by James Brown. But I have a feeling that James Brown's goal was one hundred percent. When other artists released three or four records per year, James Brown bombed the audience with records. It was one single per month or twelve every year, half of them tough dance tunes, plus three ballads and standards and one or two instrumental organ songs plus a Christmas song. He 
also re-released earlier studio recordings with audience added. There were several new LPs every year. He produced records with other artists in his own stable and with his own orchestra.

James Brown no longer created hits like other artists, but one song flowed into the other and made an ongoing soundtrack to the life in the ghetto. Most important perhaps, by releasing so many records, there was no need or room for cover artists and plagiarists.

In 1968 I certainly had ninety-nine percent of everything he had recorded himself and a lot of what he produced with other vocalists. But as a producer for others, he had very moderate success. They got only the remnants left over from his own table, and his efforts with artists such as Yvonne Fair - where her "I Found Out" eventually became his own "I Got You" was the exception, as well as some good singles by Bobby Byrd and Baby Lloyd. While his competitors had songwriters, producers and organizers James Brown even did this himself ... Which made his recordings sound more and more the same.

While dance songs like "Night Train," "Out of Sight," "I Got You (I Feel Good),” “Papa’s Got a Brand New Bag” (1962-65) had been innovative, I thought the songs he released in 1968 began to sound a bit tiresome.

But after all, from this flood of sometimes mediocre record releases, you could still pick up more soul and $R \& B$ classics with him than with his contemporaries (Clyde McPhatter, Brook Benton, Jackie Wilson, Sam Cooke, Solomon Burke, Wilson Pickett, Otis Redding, Sam \& Dave and Joe Tex and others). 
He actually recorded soul already in the early 1960s. More than any other artist he deserves to be called the founder/creator or originator of soul. Musically, the first half of the 1960s is his best. (Already in 1962 Jimmy Jones did a tribute to him with Dynamite on the Parkway Records.)

No one worked harder than James Brown, even off stage. He missed no opportunity for promotion and had the phone number of every disc jockey in the US in his head. During a live broadcast at Waxie Maxie's record shop in Washington, James Brown showed up in the middle of the program and promised that all the listeners who came there with a used toothbrush would get his new record free in exchange. Within thirty minutes he had 500 used brushes and 300 newly purchased ones left there.

I guess James Brown experienced a sense of failure if the number of tour gigs were below 365 per year. He also often recorded at night after an evening show.

He was the highest paid black entertainer.

I am convinced that if he instead had focused on gospel music he would have taken over from Archie Brownlee as the no 1. male gospel singer. His Famous Flames could have been as famous as the Five Blind Boys of Mississippi. Archie, who died at age 35 in 1960, had an unprecedented ability to transmit a parish into a bunch of talking tongues, doing sacred dancing and screaming ecstatically. This was the ability James brought from the churches to concert halls. This was the kind of audience 
reaction he wanted. I don't think any other soul artist did a better job.

The black (male) show business history is full of great performers: Cab Calloway (1930s), Wynonie Harris (1940s), Roy Brown (1940-50s), Jackie Wilson 1950-60s and James Brown (1960-70s). But it is probably only James Brown who had been the absolutely outstanding stage artist of his generation. At his peak, James Brown was probably the most exciting of them all. It was often reported that James Brown passed out after performances due to nervous exhaustion, or acute dehydration due to sweating, and that he needed oxygen and massage after each show to survive.

In short, James Brown was "The Hardest Working Man in Show Business" or "The Godfather of Soul.” Although James Brown rarely mentions any of his own inspirations there is the $R \& B$ group the Five Royales, which began as a gospel group the Royal Sons Quintet, and Little Willie John, who he recorded a tribute LP to and Roy Brown of course.

It's also interesting to see that he, unlike many other soul artists, actually moved freely in the 1940-50s repertoire when he rerecorded it, sometimes twenty years later. That he is said to have an elephant's memory is not contradicted by recordings like "I Love You Yes I Do" (Bull Moose Jackson), "Why Do Everything Happen To Me” (Roy Hawkins), “Ain’t Nobody Here But Us Chickens" and "Somebody Done Changed The Lock Of My Door” (Louis Jordan), “Good Rockin’ Tonight” (Roy Brown / Wynonie Harris), “Love Don’t Love Nobody” (Roy Brown), “The Bells, Have Mercy Baby” (Billy Ward \& 
The Dominoes), “Bewildered” (Amos Milburn), “Think, Come over Here” (5 Royales). Many of these songs had also been recorded at King, Browns record company, and been published previously by King.

James Brown was on top that summer. He had drawn 40,000 people to Yankee Stadium and earned three or four million dollars (1967). Even though he was the most popular black artist in 1968, there were still many whites who had never heard of him. It was almost impossible for a white singer to cover a James Brown song. Almost none other than The Who had dared to do this (Shout and Shimmy), and with very poor result.

He was a phenomenon and his workload was twice as much as any of his contemporaries. He had taken over more and more of his white manager Ben Bart's work. He sought to gain total financial and artistic control over all parts in the music industry and had also started a chain of soul food restaurants and radio stations etc. Psychologically he must also have been a unique phenomenon: how can one combine an unparalleled, hysterically emotional vocal career, with being an effective businessman and run a small business empire and touring the year round?

James Brown must have lived on the verge of a nervous exhaustion and mental breakdown for several years and that perhaps explains why he eventually burned out and started using drugs. (James Brown Enterprises, 850 Seventh Ave, NY. Ben Bart, Try Me Music, 200 West 57th St, NY).

I listened a lot to the radio in San Francisco, including gospel 
programs on Sunday. These are the new songs I heard, and my favourites are marked with $(*)$

Neon Kimbell-“Reservation” (*), Eddie Wilson-“Shing A Ling Stroll,” Masqueraders- "I Ain’t Got Nobody to Love”(*), The Rays- "Silhouettes”(*), Rosetta George"Waiting On You, Jesus" (*), Swanee Quintet-“I’ll Fly Away,” Helen Robinson Youth Choir - “I'm Gonna Wait 'Til Jesus Comes" (*), Professor Patton- "Wade in the Water,” Jackson Brothers - "Reunion,” Travelin Notes“Just a Little More Faith” (*), Mighty Clouds of Joy - “Call Him Up” (*), Shirley Ceasar- "IFeel Good,” Soul Stirrers"Peace Be Still," Swanee Quintet- "Silver and Gold” (*), Knight Bros - “Ain’t No Big Thing,’Detroit City Emeralds - “Take Me The Way I Am,’Dionne Warwick"Who’s Gonna Love Me" 


\section{Detroit}

August $14-20,1968$

When I arrived it took a while to find a hotel that suited my financial situation. But I could afford room No. 129 at the Virginia Hotel at 921 South Grand Ave. It cost \$8 per week. The hotel was in a large detached house and the hotel operation was more like a "bed without breakfast." I was thoroughly tired and felt the early stages of a cold. Next day I woke up at two in the afternoon because of time zone difference and jet lag. It was not until the following day I could start my research.

Berry Gordy's Motown was on top of my list. But they had moved from the intimate little building, known as "Hitsville USA” at 2648 W. Grand Blvd, Detroit 8 (Ph. 871- 3340) to a modern office building at 2457 Woodward Rd, Meadowbrook (Ph. 965-9250). There, under the name of International Talent Management, their artists were also booked, and Pat Alexander was responsible for the PR. The door was locked and the front desk did not answer the door bell. It was impossible to get in. 
I had been admitted with open arms at all other record companies, but here I was met by a closed door. I waited a long time but there was no one who either entered or left.

Returning home, I tried to call but ended up in a switchboard that connected me to the wrong people. I remember a tired man who apparently edited music at a high volume, but after three attempts I had still not managed to make myself understood or explain what I wanted. I never managed to talk to Pat Alexander or to Mr. Selzer who was responsible for the studio recordings, when I tried again after the weekend.

At this time rumors were spread that Tamla-Motown, the fastest growing and most profitable company of all sectors and branches in the US, had been taken over by organized crime. They had made an offer the company could not refuse. Maybe they didn't want to talk to journalists then. They had six or seven years of exceptional, profitable growth behind them. They were the Apple or Google of that era.

I continued to browse through the phone book, and spoke to Mrs. Burt of Magic City Records at 8912 Grand River Ave. Allen Metnick was promo man at London Records (15470 Schafr.). They distributed small soul-labels like Tribe and Watch but the Rolling Stones were their biggest artists. I think it was at Revilot they said that J.J. Barnes, later one of the great Northern Soul artists in England, performed at 2-12 Local Union Hall on Mack Avenue in Detroit's eastern parts along with Pat Lewis and The Holidays. Dean Jackson ("Love Makes The World Go Around”) was in town and performed at the Casino Royale (at Wyoming) on Friday-Saturday. The Intruders (“Cowboys To Girls”) was 
in another place. But I never got a real overview of Detroit's soul scene. No one mentioned the Flame Showbar which used to be Detroit's best black nightclub. It was here Billy "Prince of the Blues” Wright, Little Richard's mentor, staged shows and Berry Gordy worked as a cloakroom attendant and tried to sell his compositions to visiting artists like Jackie Wilson.

Saturday-Sunday Monday-Tuesday (August 17th to 20th)

The cold hit with full force over the weekend. The only thing I could do was walk around in record shops. During my round trip so far I had neither had the time nor money to do this, but overall spending so little in Detroit I could prioritize disc purchases. The record market in Detroit was very well supplied. Lots of records were available on sale. At a flea market there were perhaps 50 meters of tables with tons of singles of soul and white groups on small Detroit companies. I wrote up names and addresses directly from the labels for future research visits. From the phone book, I got additional information:

Diamond Jim Records (Riley Prod.), 12328 Dexter, Detroit (Artists: E. J. \& The Echos)

D-Town, 3040 E. Grand Blvd

Falcon Records, Fortune Records

Golden World (their group The Reflection's “Just Like Romeo and Juliet” had entered the Swedish Top Ten)

Inferno 16265 Wyoming (distributed by Motown)

Revilot (Solid Hitbound Prod) 8832 Puritan

Ric Tic Records, 4039 Buena Vista, Detroit

Thelma, 6519 Gd River

Tri-Phi (artist Harvey (Fuqua) 
416 - JONAS BERNHOLM

Wheel City Records

WheelsVille

Wingate productions - (Ed Wingate worked with Golden World and Ric Tic and could be reached on Ric Tic's address).

For a dollar you got around ten 45s. I had a decent stack in the end. A few days later I sent these and other records I had gotten for free during the trip. There were a total of 112 singles and 10 LPs. Postage cost \$7.

One Stop, Inc., 13254 Linwood Nr, Davison, Detroit distributed new singles.

I bought the books Black Like Me and Go Down Dead about the situation of Afro America in the United States. In Black Like Me the white John Howard Griffin alters his appearance and skin colour and becomes a black man in the South.

I also sent letters to people in the record business that I had met at different record companies in the United States with the hope that I would receive their mailings of new soul discs.

I listened to the radio, perhaps more than in any other city; and mainly to two stations; WCHD (Which probably just then had moved from 278 East Forest to 32790 Henry Ruff Rd) and WJLB (3100 David Broderick Tower).

While Detroit was best known for its polished soul productions there were music from many parts of the United States on the radio.

These were the best (*) songs I heard: 
Johnny Nash-“La La La” Bull \& The Matadors-“Funky Judge(Judge Sure is Funky)” Fredd ... "Too Much Monkey Business Going On ...”(*) Chuck Jackson - “Ordinary Man” Mighty Hannibal-"Good Time” Fantastic Four-“I Love You Madly” Parliaments-“Good Old Funky Music" LeeDorsey - "Four Corners" Toys - "Sealed With A Kiss” Johnny Nash-"Hold Me Tight” "Four Dells" - "If I Didn’t Love You” (*) Jerry Combs \& The Mannix - "It Takes A Whole Lotta Woman” (*) Jerry Butler-"Hey, Western Union Man” (*) Staple Singers-“Long Walk To D.C.” Jimmy ‘Soul’ Clark-“Moonie Moonie” (*) Jimmy Delphs-"Please Have Mercy, Mrs Percy”

And a very fine (almost talking) soul blues-ballad about having only 36 cents left and getting a cold by E.J. \& The Echoes - If You Just Love Me, Love Me (Diamond Jim Records) (**)

Leroy Briggs-“Going Out To Nowhere” $\left(^{*}\right)$ Sly \& The Family Stone - "My Lady” DetroitEmeralds "Showtime" "(Oh Lord) Why Am I Treated So Bad" (*) Charles Conrad - "Isn't It Amazing” (*) Jackie Beavers "INeed My Baby" $\left.{ }^{*}\right)$ The Dynamics - “Ain’t No Sun (Since You've Been Gone)” Brenda \& The Tabulations "Get Out Of My Life" Joe Simon-"Message To Maria" (*) Jimmy Cober-“Cloudy Day” (*) Ernie Dean-"I’m Alright Now” Bobby Womack-“Take Me”(*) Freddie Scott-"Where Does Love Go"Mel Brown-"Ode To Billy Joe” (instrumental) Gladys Knight \& ThePips-"IWish It Would Rain" (*) Jerry-O- "Funky Four Corners" "IOnly Get To See You On The Weekend(On The Weekend)" Gene Chandler-“Good Old Days” Barbara Lewis-"Peacemaker Girl” Ricky Lewis - "Cupid” Soul Brothers- ... around 
(instrumental) Andre Williams - “Cadillac Jack" (*) "When I See Her I'm Gonna Give Her All The Love I Got”

Musically nothing much had happened in Detroit. But on the other hand, I had cured my cold, avoided drinking and gathered strength. In New York later, I saw many Detroit and Tamla Motown Recording artists at the Apollo theater.

Perhaps it was fortunate that I did not go into the Detroit ghetto. Tensions built up during the summer exploded almost simultaneously during the riots at the Democratic Convention in Chicago. 


\section{New York (II)}

August 20, 1968

On Tuesday the 20th of August, I came back to New York after traveling around the USA for two and half months. It was tempting to register at the YMCA on 135th Street. But the Hotel Theresa, where Fidel Castro stayed on his USA visit, and where Little Willie John and other stars used to stay, had closed. (Theresa is featured in the Alfred Hitchcock movie Topaz.) Instead, my new hotel was located at 42nd street near the Port Authority Bus Terminal. It was a classic flophouse and cost \$21 per week.

The day after I went to The Apollo theater. I was used to getting a free entrance everywhere, but not at the Apollo. Honi Coles was Vivian Reed's manager. I had met her in Miami, but I did not get hold of him. I was directed to the gruesome alley (126th street) behind the Apollo. But I never managed to get in through the artist's entrance. The doorman was relentless. On the way I passed a gigantic, long bar on 8th Avenue (Braddock's Bar?), while those outside cheered. 
The Apollo staff tried to tire me out and I guess many never returned from a visit to the alley. 126th street had a reputation for being one of Harlem's most dangerous. The artists who parked their cars there had to buy back the hub caps both once and twice.

It was a claustrophobic narrow side street and the center of dice playing and drug sales. When the police arrived, the players had an agreement with the Apollo doorman who let them into safety. At least twenty years ago, when gambler Malcolm Little was a minor player in the N.Y. underworld, before he changed his slave-surname to an $\mathrm{X}$.

Finally, I got the number of Peter Long. He arranged the backstage passes. He was the PR manager and responsible for the performers. If I only contacted him tomorrow, he would arrange it.

I went home. It was late. For \$3 I could see the amateur competition, but not the entire regular show. It was said that Gladys Knight had not fully recovered from a throat ailment. She had to cancel a couple of performances.

I returned in good time the day after and was shown the rehearsal area in the basement. It had a low ceiling, and had previously been a nightclub. Here, all the amateurs were given instructions for the Wednesday Amateur night. Today a theater group (“Listen My Brother”) were rehearsing for the next seven days.

I did not meet any of the regular soul artists. I guess many showed up on Friday, just before the opening show. Reuben 
Phillips Orchestra had such a wide repertoire and ability to read music that all went well anyway. They had fifteen years of experience, after they replaced the Lucky Millinder Orchestra as house band in 1953.

Peter Long was a jack of all trades at the Apollo and had worked there since the early 1960s. He kept me company for an hour and I got to see the theater group's entire show. It was a new approach for Apollo - a Black Power theater play with soul singing, and I exchanged a few words with the actors. Peter had previously been responsible for African Holiday, one of the most successful of the shows with African artists that Apollo had arranged.

I went upstairs to the theater. It was like a big worn out cinema (1600 or 1800 seats). Not much was spent on decoration. The stage was always spartan and nothing distracted attention from the music and artists. They supposedly had 13 dressing rooms on four floors. (I did not see or visit that many) The staircase was to the left of the stage.

This week the Dynamics / Bandwagon / Edwin Starr / Cliff Nobles / Gladys Knight \& The Pips were advertised on the 125th Street marquee.

The Dynamics was a four-man group whose hit recording Misery actually had found its way to Kungsholmens Record Exchange in Stockholm and to my record collection a couple of years earlier. American Vietnam war deserters that were pressed financially sold their records and contributed to the emergence of a soul-music scene in Sweden. 


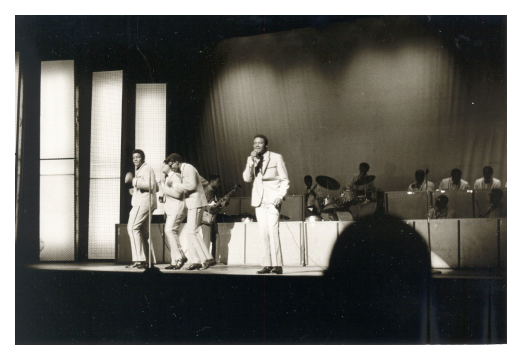

The Dynamics at the Apollo
At the Apollo they did: "It's Not Unusual," "Murder In the First Degree,” “Ain’t No Sun.”

"Murder” was especially good. It was a fine group but without that little extra that was needed to make it big.

I talked with them backstage. They were four nice guys, (especially the fattest member), in a group consisting of:

George White (1st and 2nd tenor) born in 1943

Samuel Stevenson (Baritone, 3rd tenor) born in 1942

Fred Baker (1st and 2nd tenor) born in 1942

Billy Harris (Lead, 2nd tenor) born in 1943

A fifth member "Mel West" had left the group a few years earlier.

The Dynamics were founded in 1959 in Detroit. In 1962 recordings were leased to Reprise. Then they were contracted to Big Top which released Misery in 1963. It sold 350,000-400,000 copies and "Styley Chaser" sang lead. But he was drafted and never came back to the group again.

They had a couple of records on the Top Ten label (1964-65), which were leased through Laurie Records.

Then RCA (1966-67) took care of the group and they released two singles. 
Now they had just signed a contract with Cotillion, a subsidiary to Atlantic Records. Their first single was “Ain't No Sun”/ "Murder In The First Degree” (Murder was their own favourite). Ted White was their manager.

The Bandwagon represented a new type of group. The overall impression, after all the intricate dance-steps and energetic moves and singing was over - was, like Shakespeare said: "much ado about nothing.”

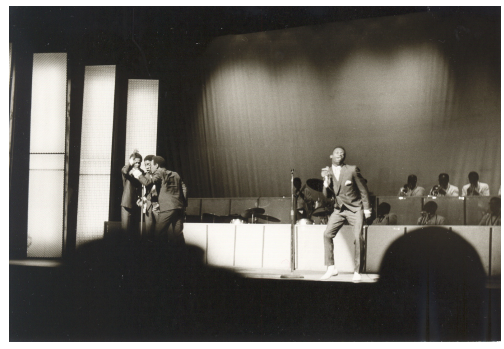

The Bandwagon at the Apollo

A fine soul group has something to say and does so by singing and bodily expressions. Here, whatever personalities the members had were overshadowed by producers and managers. This Bandwagon was driving at the same speed and used the same expression all the time - just like a later boy band.

But they were in fact enthusiastically treated by the Apollo audience when they sang: "I Could Never Love Another," "Breaking Down The Walls Of Heartache,” “Cowboys To Girls.”

The group were four guys who grew up together and attended the same school in Rochester NY - Wade Davis (Baritone and choreographer), John Johnson (Lead vocal and group business), Jerry Ferguson (Second tenor and musical arranger) and Terry Lewis (Tenor and choreographer). John and Terry sang in the same group and when it broke up they persuaded Wade and Jerry 
to join. John and Terry had a gospel background, which the other two had not. Jerry had played drums with a group called The Crusaders and Wade had sung with the Famous Flames behind James Brown two and half years ago. (I don't think he could have done so unless he was able to sing gospel ...)

They had been together for about two years. A year and a half ago they were contracted by Epic. Their first recording and success was "Baby Make Your Own Sweet Music," which was recorded in November 1967 but not released until six months later. They claimed that it had been recorded before the Jay \& The Techniques' recording. Their version sold well in Detroit, which they considered to be their home, despite living in Rochester. Their second record was "Breaking Down The Walls Of Heartache,” which just raced up the charts. They had started recording an LP. I was excited to see Edwin Starr. His reputation in soul circles was great. I had some of his Detroit singles on Golden World and Ric Tic including Agent Double O Soul. His performance was excellent. He did: "Stop Her On Sight," “25 Miles” (where he demonstrated the Walk).

I wanted to talk more with him; he seemed smart and had many irons in the fire. But we were constantly interrupted by calls from the phone outside the dressing room. He had learned the profession, he said, from Chuck Jackson and Jackie Wilson. He wanted to become a status artist - an artist who was not dependent on hit records. He had been to Europe eight times (1966-68), and he liked to work in England where they didn't forget artists who had not had a hit for a while. His own career had stalled when he did his military service in Frankfurt. He 
was with Motown and 25 Miles had been released on the Gordy label, but there was no time to talk about it. He had a background as a gospel-singer, but he did not sing in the church anymore. He did not want to be a hypocrite, so he only sang at funerals. He told me how he got everyone in the audience to clap. 'I'm just saying that those who clap their hands will win the numbers lottery tomorrow.” Everyone plays and no one dares to take the risk of losing, said Edwin Starr.

Cliff Nobles had recorded the big instrumental hit of this summer. At the Apollo, he performed The Horse twice. First a vocal version and then he demonstrated the dance with an overweight girl during an instrumental version. It was a rather tired appearance that culminated when he rode around on a broom stick - like a horse. His backing group had been with him for nine months. I met them in the small and crowded room at the top of the stairs.

Benny Williams (bass) was born in 1932.

Bobby Tucker (guitar) was born in 1938. He had played with Buddy Guy, Sonny Boy Williamson and Harold Burrage in Chicago.

Tommy Soul (drums) was born on April 7, 1944. He did a drum solo on stage and in his resumé was a gig with James Brown when his drummer became ill. He had played with Don Covay in 1962 and with Bill Pinkney and his Original Drifters.

When the interview with his group was finished, I met Cliff coming up the staircase. He had been out, probably at 
“Braddock’s Bar.” He was half drunk and looked a bit worn out. This summer had certainly been very busy.

He was a vocal artist who happened to get an instrumental hit. This was a once in a lifetime opportunity. The chance to repeat this feat was minimal.

Previously he had recorded three songs on Atlantic ("My Love Is Getting Stronger” / "Let’s Have A Good Time” / "Your Love Is All I Need") and on Phil La of Soul, he had released "The More I Do For You Baby” and “The Horse” and an LP with odd tracks; some had not much to do with Cliff. The sequel was ready: "Hey! Judge Baby I’m Back” / "Horse Fever.”

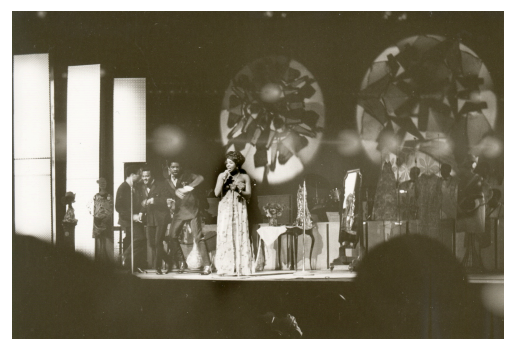

Gladys Knight and the Pips at the Apollo
Gladys Knight had been one of my favourite singers for a long time. I was especially impressed by her version of Giving Up on one of the classic "Bell's Cellar of Soul” albums that were released in England.

She stood almost motionless while the Pips hovered around her with very graceful and intricate movements when she sang:

"Walk In My Shoes,” “The End Of Our Road,” “The Masquerade Is Over," "IHeard It Through The Grape Vine.”

They had been performing to full houses throughout the week. She had regained most of his voice. Earlier she had been forced to go out on stage, to present herself and bow and then sit 
on stage and see the Pips appear without her. Edwin Starr had helped her with a guest appearance on "I Heard It Through The Grape Wine” while the Pips were singing and dancing.

Louis Jordan, who was asthmatic, always complained about the poor cleaning practices at the Apollo. He used to put a mark in the dirt and dust backstage. When he came back the next year, it was still there. He claimed that the air was so full of dust that he became hoarse every time he appeared there.

Maybe Gladys had the same problem.

She was one of the most charming female singers I had ever met. Gladys and her group, The Pips, had been together for 15 years. In the beginning there were two girls and only 3-4 years ago the last male Pip joined.

Today there were three male Pips. They were also related to Gladys. The “original” Pips sang gospel music and were then called The Fountain Aires.

Gladys was born in Atlanta, where she and the Pips were discovered by the DJ and promoter Zenas Sears and by Chuck Willis. Now she lived in Detroit. They broke up 5-6 years ago when Gladys was pregnant, and went their separate ways for a while.

William (of the Pips) had an excellent memory and helped Gladys to remember all the names so she wouldn't make a fool of herself. They have written songs together, among them Darling. 
Gladys had a very positive way to talk about her hard-earned lessons in the music business. She said she was grateful for the people she met and who taught her everything about the industry's "bad guys." She meant the people at the beginning of her career. Before Motown she had never received any royalties. And then just enough to pay debts.

She was also happy that after Marguerite Mayes, one of their managers, she got another who taught them to avoid the people who took all the money and instead seek out those who left little behind ...

As a solo singer Fury Records released "Come See About Me," and she recorded six other sides, still in the can. For a year Smokey Robinson tried to get her to Motown, but she was afraid to be lost among all the other artists. But when Gladys had decided she wanted to have a contract with Motown, it took over a year before the company said yes.

Charlie Atkins, who was the Motown choreographer, taught them stage presence and gave them dance lessons five years ago when he was not under contract to Motown. They knew Maurice King, musical director at Motown, in Detroit long before he came to Motown.

Gladys had just finished a two-week engagement at the Copacabana. She was the first act in twenty-six years to be late for her own premiere ...

A blind girl came in to talk with Gladys. I think she had won the amateur contest the day before. I said goodbye to Gladys and 
walked by the door watchman on my way back. He had a real stone face. The film was over. I was thankful I didn't have to see it. Time for the next show ...

Tuesday next week, I went back.

The program was:

The Esquires

The Vibrations

The Marvelettes

"Listen My Brother" - the musical show.

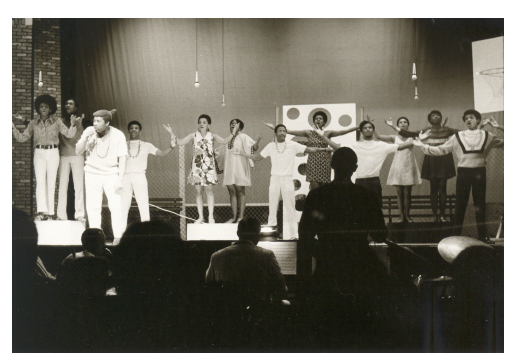

From "Listen to my Brother" at the Apollo

This week they also had a white comedian.

The lobby of the Apollo was a meeting place. There you ran into lots of artists and industry professionals. Before the show I noticed a gospel artist (and his wife).

On Sunday, he had been so filled with the Holy Spirit that he had to be carried out of the church. He could not stop singing. Now it was Soul Time at the Apollo..

In a corner, I saw the Swamp People - Al \& Jackie (Jackie Porter and Albertus) whom I met in Miami with soul queen Betty Harris. I sank into sweet memories but was interrupted by a woman who tapped me on the back. I turned around and immediately recognized Vivian Reed - nine years later a big star on Broadway in Bubbling Brown Sugar. Her French fans called 
her "Miss Ten million Volts." She became very hot there. We had met in Miami at the Foxes Den six weeks earlier. She was back at the Apollo, where she got her start through her manager, Honi Coles.

(Thirty years later I must confess that I have neither before nor later attracted the attention of a more beautiful woman in a public place. At the Apollo nothing was impossible.)

The Esquires were four men and they were accompanied by their own, rather mediocre backing group. They were good singers, but I thought they gave bass singer Mill Edwards/Evans too much space. They had an energetic stage show and sang ... "And get away," "Get On Up” (It is actually the same song...) and then Mill sang of song of his own.

The group:

Gilbert Moorer (Lead) was born in Milwaukee in 1941 Alvis Moorer (Baritone) was born in 1940 in Milwaukee Sammy Pace (Tenor) was born in Kansas in 1944

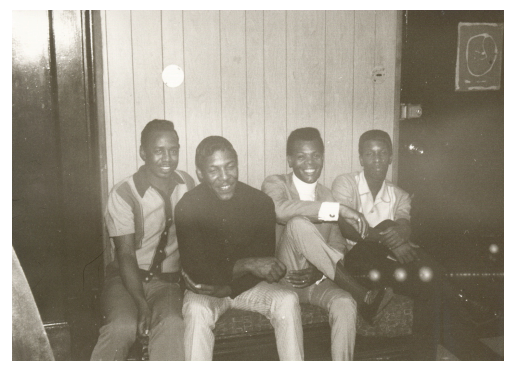

The Esquires backstage

Mill Edwards (bass) was born

in 1940 in Indianapolis (He also sometimes called himself Evans):

Mill had been with the group the Sheppards on the Apex label (1959-61). Their most famous recording was "Island of Love." He also recorded under his own name on King and Tousea 
before he joined the Esquires; just before the recording of "Get On Up” on Bunky Records.

Reuben Phillips and his orchestra resumed their place on stage to accompany the Vibrations. They started with "Funky Street," where the Vibrations made a break for a comical quarrel. Then a fine version of "Misty," where Ricky Owens sang lead with his classic high tenor falsetto voice. A third fine song followed. Vibrations was an experienced five-man group that perhaps joked a bit too much on stage. They were not as funny as the Coasters or the Cadillacs.

I had heard some of their Checker and Okeh recordings. They had been together almost as long as the Dells (since the mid-1950s). It was obvious that they were hoping for an equally successful comeback. They were not so happy about their contract with Okeh (Columbia) (without comparing their situation with Aretha Franklin who had been trapped on Columbia before she blossomed at Atlantic). They had eight months left, and counted the days.

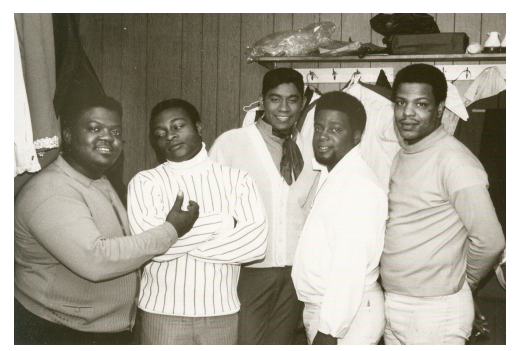

The Vibrations backstage

David Govinda (lead, baritone)
The Vibrations were a bunch of nice guys from Philadelphia with great experience in the industry and consisted of:

Carl Fisher (2nd lead),

Don Bradley (bass) - the group clown 
Ricky Owens (tenor)

James Johnson (1st tenor - lead).

In retrospect, I best remember Ricky Owens. He was very taciturn. A little later he entered the turbulence surrounding the Temptations triggered by the firing of David Ruffin. Ricky was a great ballad singer, and sang like Eddie Kendricks (whom he was going to replace?). But he stayed only a short while with the Temptations.

Listen My Brother was a theater play with a group of young people who illustrated situations in the ghetto with songs like "We're Gonna Make It” / "Learn Something” / "African Hairstyle" / "What Is Love" / "Where is Tomorrow."

There were less people this evening than the other times I visited the Apollo. The Marvelettes were perhaps not strong enough to be the main attraction and the Vibrations had not had a hit in a long time. I thought this theater piece was good, but then I was easily swayed when the theme was the Black Panthers and Black Power. The play probably didn't have that much local attraction for paying customers.

The Marvelettes' stage performance was professional. They were three girls then. Wanda was a great singer and the girls backed her meritoriously, while they stood pretty still on the stage.

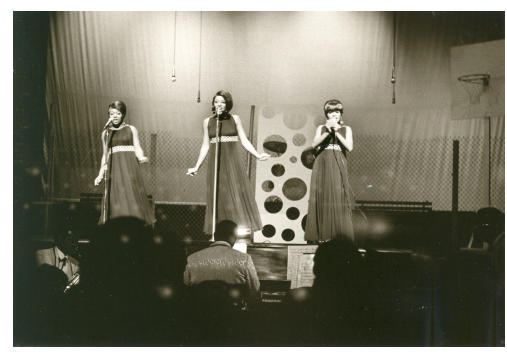

The Marvelettes at the Apollo August 27, 1968 
Much has been said about the Motown choreography. I think it was overrated. Many Motown groups were rather drab on stage and stood still most of the time. First and foremost, it was hard to duplicate the Motown sound. Then they never managed to get close to the uninhibited choreographic expression that Ike Turner created for the Ikettes and Tina. Or that which James Brown created for himself and the Famous Flames. The Motown performers learned the basics, but not much more, unless they were exceptionally gifted like the Temptations or the Supremes. Besides they had too many hits at Motown. Their choreographer simply could not choreograph each new hit. Many Motown artists lacked stage routine, since they became popular so quickly through recordings. (Much was said about Motown when I visited Stax in Memphis. I might be biased here...).

The Marvelettes sang the following songs: "You're in Love" (Lead: Wanda), “Here I Am Baby” (Lead: Wanda), “The Hunter Gets Captured By The Game” (Lead: Wanda), “Too Many Fish In The Sea” (Lead: Anne).

In the conclusion followed "Listen My Brother." I think the Marvelettes sang it along with the theatrical players. It was a traditional finale with all gathered on stage at the same time.

From the beginning they were five girls from Inkster, a suburb of Detroit. Gladys Horton sang lead on songs such as Please Mr. Postman. Between performances, the girls read schoolbooks and did their homework. Eventually Wanda Rogers took over when the group was transformed from a girl group to a soul group in the mid 1960s. Her voice can be heard on classics like “Don’t Mess with Bill” or “The Hunter Gets Captured By The 
Game.” Wanda, who was small and had a fine, curved nose, was married to Bobby Rogers of the Miracles. He was the most muscular member of the group and on album covers he often wears distinguished horn-rimmed glasses as Detroit's answer to Bo Diddley.

Wanda was four months pregnant and the Rogers family expected an addition in January 1969. On the album cover of Season for Miracles (1970), we can see that everything apparently went well. Wanda is holding a child in her arms that appear to have passed the acute stage of lactation, while Bobby dedicates himself to a girl and a boy of about five and three years of age.

Wanda sang lead on the flip side ("So Long Baby") of "Please Mr. Postman,” but not anymore. It was too high and she would lose her voice if she tried.

Anne Bogan had been recruited in February-March the same year that Gladys left. She was bigger on the cover of the LP Sophisticated Soul than on stage at the Apollo. But it seems unlikely that she had put on weight since she came to Motown. The fate of Florence Ballard in the Supremes must have discouraged any over eating among Motown stars.

Anne was born in Cleveland and started in the gospel music industry. First with the Cleveland Gospel Aires (there were three different groups called the Gospel Aires ....) and The Grace Inspiration Singers. But she did not do any recordings. She left gospel music and sang lead with the Challengers who had a hit, Honey, Honey, Honey on Harvey Fuquas Tri Phi label. She 
did not mind singing $\mathrm{R} \& \mathrm{~B}$ as long as the songs had a message. When Gladys left the Marvelettes, Motown had an audition. Harvey, who now worked at Motown, remembered Anne and sent for her, and she was chosen.

Katherine Schaffner, had been with the group from the beginning. She was very fond of English spoken with a European-accent (like mine) after a period of illness eleven years earlier when she was cared for by a Hungarian nurse. Katherine was also married.

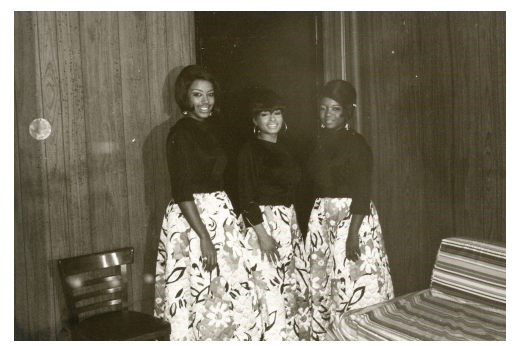

The Marvelettes backstage

The Marvelettes were the main attraction at the Apollo that week and had the finest, largest dressing room closest to the stage. Gladys Knight had hosted there the week before. From there a spiral staircase led upstairs. On top beginners and has-beens had to settle in narrow and crowded dressing rooms.

During the English tour a few years earlier they had only mimed when they appeared on TV. They thrived in Europe which they found clean and tidy and not as crowded and overpopulated as the US cities.

I parted from these three nice women.

The movie had been about a baron and "scientist" who had produced bloodsucking and man-eating trees in his greenhouse 
laboratory. But when they forgot to close the windows most people were eaten up.

Before cable TV and video stores these kinds of films were never seen in Sweden. The Swedish film censors succeeded in keeping an acceptable level of film artistry back home.

The Last Show

The next stop was Kennedy airport. I picked up my suitcase and dragged it up to the Port Authority Bus Terminal. It was midnight and the plane would leave at five in the morning. But after a while in the plane, we had to leave it. An engine had caught fire and we were accommodated in an airport hotel until they found a replacement plane.

Two days passed. I spent most of the time at the hotel and watched old movies on TV. The departure was finally to set to Friday evening. I scraped my last cents together for a commuter ticket and went to Harlem.

\section{August 30, 1968}

Friday afternoon the next week's show opened. Photos were not allowed nor any interviews. I had not a penny in my pocket but was hoping to get in free. While I stood there and waited an elderly, bespectacled white gentleman around 75 years of age came up to me and we started talking. He was dressed in a simple cardigan sweater. He looked like an old school teacher, and that was also his professional training at the beginning of this century. It was difficult for me to hide my enthusiasm and 
fascination for the Apollo and its artistic tradition. I began to tell him what I'd been doing this summer.

He introduced himself as Frank Schiffman, owner and founder. He briefly outlined the history and how everything had started with the Lafayette Theater already in the 1920's with artists like Bessie Smith, Louis Armstrong, Fats Waller and many more. He also talked about his time with the Harlem Opera House. When he realized my financial problems he put his arm kindly around my shoulders and took me firmly past the tough door guards. It was a prophetic moment:

Frank used to put his arms around artists who didn't measure up and were fired. I never came back, either. The Apollo Theatre closed a few years later.

But now I could enjoy another fantastic show at the Apollo with The Monitors / Shorty Long / Junior Walker / (Smokey Robinson and) The Miracles - A real Motown extravaganza.

The Monitors consisted of two men and one woman. They stood still all the time when they sang.

"Say You” - their hit song - sounded really good.

Then followed a Delfonics inspired "I Only Have Eyes For You" and ultimately a mediocre version of The Impressions' "We're a Winner.”

The group was not very experienced and it shone through. They wanted the audience to repeat "Oh Yeah” but did not get much 
of a response. I had seen both better and worse groups than the Monitors.

Shorty Long was very short and came on stage wearing a white wig and robe. First he sang a duet with a two meter long woman (“Never Gonna Give You Up” - Eddie Floyd’s hit song). Then came the Motown version of this summer's second scourge alongside the Horse, namely - "Here Comes the Judge." The Judge routine had been introduced back in 1929 and bubbled for 39 years before it exploded in the summer of 1968 with a hit single on Chess by Pigmeat Markham.

Shorty was acting a scene where he asked people for "Order in the Court" and he ordered the accused to raise their right hand. Then he rushed forward with a deodorant to take care of a bad smelling armpit. Finally, he waved his revolver and gave out harsh punishments such as "30 Days of Shing-a-ling." He ended the show with his classic Motown stomper Function At The Junction.

Everything was not perfect yet. When Shorty said "everybody" to make room for the full orchestra, they believed that it was time for a guitar solo instead ...

Shorty's life ended shortly afterwards in a car accident. I think he was one of the very best of the lesser-known Motown artists.

Junior Walker bounced out on stage wearing a pink suit with his All Stars standing behind. He started with a short version of The Horse and then presented himself and his band.

Then followed a string of hits like: 
"Shake and Fingerpop," "Road Runner," "Cleo Is Back" and "How Sweet It Is To Be Loved By You" - while the audience joined in the choruses, and finally Shotgun where Jr Walker had a duel with his guitarist whose noise level, unfortunately, was too high all the time. (Especially on Road Runner.)

Junior was full of energy and power and not nearly as polished or sophisticated as most other Motown artists I've seen. His style was quite raw. It was fun to see him live and to hear this string of amazing soul instrumentals (often with vocal chorus), although he only rarely improvised, or spread out, but mostly stuck to the short-short single format. A great saxophonist!

Smokey Robinson \& The Miracles

Smokey stood in front with the other three members behind him. Each had their own microphone. Despite the fame of Motown choreography, the Miracles were another still-standing group. The compensation was Smokey's expressive face, which changed with the lyrics. They did:"I Second That Emotion.” On "Talk About Love” the group took up maracas and tambourines.

Smokey asked if anyone had loved without being mistreated or not loved but treated badly - then Say Yeah!

The majority of the audience respond with an unison Yeah!

"More Love" followed and then "Yester Love" where Smokey had to clear his throat a few times. Then he wanted to sing a "sad song." The crowd responded with cries and shouts when the introduction to "The Tracks of My Tears" rang out. 
It was a great moment to hear this song live. The best Motown ballad of all time. Even Bob Dylan called Smokey USA's foremost contemporary poet after hearing this recording and Smokey’s lyrics.

"Special Occasion,” “Theme from Valley of the Dolls," "If You Can Want” and “Ooh Baby Baby” followed.

The finale was "Going To A Go Go." The audience again responded with screams. Smokey ended the show by taking a few dance steps and the show was over. A better ending to three months in the US is difficult to imagine.

When I arrived back at the hotel the bus to the airport was waiting and left almost immediately.

The airline tried to compensate us for the delay and offered free drinks all the way home. (They were not familiar with Swedish binge drinking culture and habits.) It was a big plane with two levels and a staircase leading up to an airplane bar where we stood and cheered and toasted while the sun was rising over Greenland. When I got back to my seat after a few hours, I discovered that my neighbour, a "happy" student from Lund University, had been sick and vomited straight down into my hand luggage bag. There I had neatly stacked 200 singles. I had to rinse off the top layer of $45 \mathrm{~s}$ and dispose of paper sleeves when home again.

Between visits to the Apollo and various record companies, I was out looking for records. Colony was an excellent openat-night record store on 1671 Broadway where I spent much 
time going through their stock of 45s. According to them, it was the second largest record store in the United States. Jimi Hendrix had been there and bought records last year but there was still a lot left. They must have had 50,000 singles sorted by record labels on the shelves. When the clerk understood what I wanted he put "Sea Cruise" by Frankie Ford on the turntable and spun around doing the Twist. I bought a decent bundle that was crowned by “It's All Over Now” by The Valentinos.

On 1595 Broadway was Oldies Records. They displayed VeeJay LPs with the Dells and the Eldorados etc. in the window at $\$ 25$ per LP. (At NK in Stockholm the same records were on sale for $\$ 1.50$ each.) There, I met Shelley Weltman who later started Oldies Unlimited in Flushing.

Unfortunately, all the mono LPs on Atlantic with Ruth Brown, Clyde McPhatter, Big Joe Turner and others had sold out during the summer. Only an occasional Drifters LP could be found.

On Saturday I went to Harlem and bought records along 125th street. When they realized that I was looking for older records, the clerk in a store asked if I was interested in a Chuck Willis LP (on Okeh/Epic). Which I was of course and paid \$3 for it. At Bobby's Records I bought Erma Franklin's Piece of My Heart on Shout, now better known in Janis Joplin's version. When I walked along Lenox Avenue I found a small record store. They had a box of soul-singles on the floor. How much are these, I asked. You can get them for free, the clerk said. I didn't dare to take all but picked a decent bundle of small soul-labels from New York. 
It was difficult and complicated to import records from the United States. Albert Schultz and David Eskin exported LPs that were still in the Schwann catalogue. Then discs stayed in the catalogue for many years. I had established contact with King Karol in New York. They had a good stock at 111 West 42nd Street. I bought the Fever King-45 with Little Willie John there. I also visited the House of Oldies at 267 Bleeker Street. Junior Wells appeared simultaneously on Cafe' Au Go Go on 152 Bleeker St, but I never had time to go there ...

Among the highlights in the United States were the church concerts. As I walked around Harlem I was always looking for posters about Gospel concerts. Once in a while a church used to have a large program with many gospel groups. This Sunday, around noon, I was on my way to the Corinthian First Baptist Church at 116th Street and Seventh Avenue in New York.

The program began with a sermon from the church's priest. Then came the Sheppard Singers, a seven-man group. They brought no singing surprises but they had a couple of fine guitarists and the group was in a good mood.

Clarence Fountain, better known later as the lead singer of the Blind Boys of Alabama, had left the group and tried a solo career. He had a fine Ray Charles-like voice and did well. After the performance the priest stood next to Clarence and said that he was sick. They had to collect money for his medical expenses and the ticket home.

Mighty Gospel Giants of New York were just excellent. Especially prominent was a little guy with a high Little Richard- 
styled hairdo. Both the group and the audience were feeling good.

Skylight Singers were the highlight of the day. The group sang wonderful harmonies behind the lead singer who came in ecstasy, and did not want to leave. He rushed around among the crowd in the pews, kneeling down and preached and sang alternately. In the end, the group's other members had to lift him up and carry him out. A couple of days later I saw him in the foyer at the Apollo ...

Sandra Brown was a corpulent singer whose talent was not as big as her body, unfortunately ...

Highway Q.C.'s did a fine performance, but left a mixed after taste. The lead singer delivered a speech where he talked about the corrupt secular soul-industry and the artists who had betrayed their vocation and sold out. (Sam Cooke had been with the Highway Q.C.'s). He also said that they did not have time to stay and sing for long as they needed to perform at several places this Sunday to earn the necessities of life ... He seemed quite bitter even if he sang well. He certainly had not the charisma of Sam Cooke ...

Swan Silvertones is one of my all time favourite groups. Then, lead singer Reverend Claude Jeter appeared solo without them. Many connoisseurs rate him among Gospel's all time best artists. But of course it was sad that he was not connected with the Swan Silvertones any longer. 
He was in a good voice and did a fine performance. Between songs he preached and spoke in a cultured and intelligent way.

A couple of solid white-clad nurses kept close watch on the crowd.

A woman quietly went around in the audience and demonstrated a battery-powered hand held fan to use when the music was too hot.

Not all groups announced arrived. The following were missing:

Golden Leafs - Rev Julius Cheeks

5 Singing Stars (Washington)

Highlights (Brooklyn)

CBS Trumpeteers (Baltimore)

Had Julius Cheeks been there these nurses might have had to take care of me. His vocals can make Wilson Pickett seem softspoken or quiet. I also hold the (CBS) Trumpeteers recordings (Nashboro) very high. Both groups had certainly given memories for life if they appeared.

Strange enough there were not so many people there. The house was far from full as I remember.

The last week in New York, I visited various record companies. In New York, the record business was centered on Broadway and around Times Square, within walking distance from the hotel.

I sat down with the yellow pages and supplemented the 
addresses I had taken from record labels. Many major labels had started their own soul labels or hired soul artists.

But it was a different pace in New York. In the South, you could just drop in for a few hours. Here previous appointments had to be made.

I visited:

ABC 1330 Ave. Americas

Atlantic 1841 Broadway. Their studio was at 11 west 60th street (PR:Bob Rolontz)

Bell 1776 Broadway

Brunswick 445 Park Ave

Calla 17 West 60th St

CBS (Epic) 51 west 52nd St (With subsidiaries Okeh och Date)

Decca 619 West 54th

Jay-Gee 1790 Broadway (Jubilee - Josie)

Jubilee 318 W. 47th Street (ware house and One Stop) PR: Elliot Blaine

Laurie 165 W. 46 PR: Dick Vanderbilt

Mercury 11 west 57th St PR: Diane..

MGM/Verve 1350 Ave of Americas PR: Sol Handwerger

Musicor 240 W 55th Street

Rojac 1274 5th ave

Roulette 17 W 60th PR: Red Schwartz

Scepter/Wand 254 West 54th Street

I did not get much help at Atlantic. I spoke with Bob Rolontz but neither he nor the Atlantic archives had any information about artists like Professor Longhair, the Top Notes or the Clovers. 
I was already a member of the English fan club Uptight and Outasite (The Atlantic-Stax Records Appreciation Society). There I was informed about all their soul artists.

In the Josie/Jubilee warehouse I got a free hand to pick records from their inventory, but had difficulty naming artists from memory. I got a nice bundle, though.

Maybe Elliot Blaine, in charge of the publicity, had a premonition of the terrible tragedy that would occur here a few months later when everything burned up. Or was it arson?

At Laurie Records, they were friendly and I had a little chat with Ernie Maresca. He was happy to be reminded of his Swedish Top Ten success with "Shout Shout (Knock Yourself Out).” In the US, his work with Dion and the Belmonts were more well known.

I accompanied him when he went out for lunch. He asked how Larry Finnegan did in Sweden, "I heard that he has opened a hot dog stand in Sweden,” joked Ernie. "He must be doing well” (In fact Larry's “Dear One” had topped the charts in Sweden).

In the summer of 1966 I was drafted. Larry Finnegan came to the Wämö arena in Karlskrona. Our gang of navy soldiers heckled during his performance and pushed ourselves into his dressing room afterwards. We did not really hold his work in high regard. He looked surprised and maybe a little afraid. He died young, and I hope he has forgiven me for this lack of respect.

I knocked on Rojac's door in an apartment building at Central Park. I had seen that Big Maybelle was in town, but no one was 
there. She was due at a big arena along with Marvin Gaye and many others shortly after I left the United States. At the same time I saw Marvin Gaye in sunglasses exit a shop across the street on Broadway in a canary green suit.

I often passed Lloyd Price's Turntable Club at Times Square. It was always closed. Lloyd's business partner Logan was found shot dead here.

The Brill Building, at 1650 Broadway, was like a children's Christmas calendar. Many record companies were here and songwriters were busy composing.

I ran around in the corridors and rang on many doorbells waiting breathlessly for what would appear behind the closed doors. It could be free records, photos and publicity materials. Or chats with veterans of the record industry.

Buddah (Room 508)

Diamond

Gamble (Room 304 A)

Scepter/Wand Publishing

Shout (Room 611)

SSS (Room 1114)

Windy City (Room 1409)

And more.

I wanted to talk to Bert Berns at Shout Records. But that door was not opened.

The Gamble record company was best known for the Gamble 
and Huff team and their productions with Intruders ("Cowboys To Girls"), and Dee Dee Sharp ("What Kind Of Lady") and the Delfonics:

Bobby Marchan's “Ain’t No Reason For Girls To Be Lonely” had sold 150,000 copies recently, and Gamble also had Ruth McFadden, and the white pop group Jaggerz in their stable. At Gamble Records I met a veteran, Sam Goldner. Sam's cousin George Goldner had been one of the most successful producers in the 1950s and worked with, among others Frankie Lymon, Little Anthony, Cleftones, Heartbeats, Flamingoes and others on labels like End and Gone. It was an era very little known in Europe at the time.

Sam opened his desk drawers and picked up some old promotional singles on End and Mark X that he handed to me.

Don Paulson worked at Richard Gersh Associates (200 W 57th $\mathrm{St}$ ). It was a public relations agency that sent out publicity material from many different record labels and artists' agencies. Don had worked at $R \& B$ fanzines in the past. He provided me with publicity material for several years.

During my walks I ran into the manager of the Blades of Grass twice. We were doing the same round. He had a Frank Sinatra toupée and wore black clothes in a gangster fashion and tried his best to present the group and get past the wall of disinterest from the record companies.

Sue Records was Juggy Murray’s company. He was not in good health, he said. He had heart problems and he had also had 
financial problems. But those were solved when he sold masters with Baby Washington and the Soul Sisters. On his office walls were pictures of the Sue performers Ike and Tina Turner and Inez and Charlie Foxx. He was working with new artists like Lucille Jackson / Billy Nickels / Candy and Cookie and Betty Brewden. But his best success to come was Wilbert Harrison's Let's Work Together, I think.

Bobby Robinson

In New Orleans, I had gotten to know Allen Toussaint and Marshall Sehorn. Marshall drove me around New Orleans, and to Huey Smith's apartment near The Dew Drop Inn, and gave me the address to Bobby Robinson in Harlem. Marshall had worked for Bobby at the beginning of his career and had also brought over Wilbert (Kansas City) Harrison to his own companies (Sehorn and Neptune).

One afternoon I knocked on the door to a corner apartment in Harlem at 2333 8th Avenue and 125th street where Bobby was furnishing his new headquarters. Bobby had reactivated his Fury label and had recently spoken with Marshall and was forewarned about my arrival.

His roster of artists was then Ricky Lewis, who had a decent hit with Cupid and Tarheel Slim (= Allen Bunn), Big Boy Larry Johnson and Buster Brown.

Don Gardner and Dee Dee Ford had plans to team up again. Johnny Jones was a great gospel singer from the Swanee Quintet. In the summer of 1968, he had had decent success 
with his version of “Tennessee Waltz," and I had met him in Miami. Through the years I have become increasingly fond of this gospel group. Something I share with James Brown, who often used to guest the group's appearances in Augusta and brought them on tours with him.

He produced one of their biggest successes "Try Me Father" - a gospel version of his own hit Try Me.

The past four years Bobby had worked with the Enjoy and Everlast labels and their Elmore James reissues, Les Cooper and others, and with his record store - Bobby's Records - on 125th street.

I rank Bobby as number one when it comes to producing R\&B. One gets goosebumps listening to a 78 on the Red Robin label - For example Champion Jack Dupree’s Shim Sham Shimmy or the Du Droppers (“Can’t Do Sixty No More”). They have an incredibly swinging backbeat and a weight and authority that is devastating. The engravings are so dynamic that there is more music in an old Red Robin 78 than on any digital CD I have heard.

Bobby looked like Heile Selassie - the "Lion of Juda.” Both have the same bushy hair and are small and slender. For unknown reasons Bobby had a remarkably long nail on his little finger - for good luck?

All record industry executives and authorities, who were on their way to the Apollo theater, passed by Bobby's Records. They asked Bobby for advice and what he thought would hit. He was 
right about most things, and in November 1951 he started the Red Robin label.

In retrospect, what grieved him the most was that he lost Frankie Lymon.

Bobby had begun rehearsing with The Teenagers when they were picked up by George Goldner. Instead, he got Frankie's eleven year old brother Lewis. Maybe that's why Lewis Lymon's recordings have such a good reputation.

Bobby was often at the Apollo and especially at the amateur evenings. For a while he had thirteen different artists and the majority of those he had discovered there. The Schiffman family also asked him about upcoming artists that sold well.

Bobby showed me around and pulled out a large cardboard box with Fire and Fury singles. That was all that was left, he told me. He had sold his entire stock (thousands of 45s) for maybe ten cents each.

He was kind enough to hand me Don Gardner \& Dee Dee Ford's I Need Your Lovin’ and Wilbert Harrison’s “Goodbye Kansas City” but he never found Dr Horse’s “Jack That Cat Was Clean” in an original Fire pressing.

These years, remarkable releases appeared on Guy Stevens' Sue label in England. All of them were probably not legitimate. The nature of the relationship between Sue in USA and Sue in England is clouded. But Guy had a great musical taste and seemed especially fond of Bobby Robinson, Johnny Vincent's 
(Ace) and Juggy Murray’s contribution to the American cultural history.

In 1978 I took the bus to 125th street. The Apollo Theater was closed but used for TV shows and recordings. Bobby Robinson was at his Hit Town One Stop which was located at 301 or 611 West 125th Street. I got the address from Bobby's Records.

I continued walking and passed by large high-rise projects, and finally went down under the elevated subway and its concrete columns until I came to Bobby's fairly inconspicuous warehouse premises, where he worked with his brother Dan.

It was a pretty scary neighbourhood and not so convenient to walk there alone in the dark. But one never learns.

Bobby had kept his bushy hair and the long little finger nail. Timid and somewhat taciturn, he started talking about Elmore James (1959). After rehearsals in his apartment in Harlem he knew that Elmore was on top. He rented a studio and in the middle of the night went there. Elmore recorded The Sky Is Crying. Bobby had an amazing ability to squeeze a little extra out of his artists, whether it was Elmore, Lightnin' Hopkins (Mojo Hand) or Buster Brown (Fannie Mae). But now he and his brother Dan were mostly involved in record distribution.

The Apollo was closed in 1978, but Teddy Pendergrass name still remained at the marquee. In the foyer of the Times Square Motor Hotel, where I stayed in 1968, were hard painted black women in furs, hot pants and white wigs surrounded by black 
men with elegant hats and super fly outfits. All seemed to use the same tailor as Johnny “Guitar” Watson.

A new kind of body work had entered "my" motor hotel. The area around 42nd street had become the center of the sex industry and sales of marijuana.

The photo studio for artists publicity photos, James J. Kriegman were in the middle of Times Square. They still had the white grand piano that had been used on so many publicity pictures. They gave me a bundle of old photos. 


\section{Conclusions/Summary}

Billboard Soul Charts

In 1967 the Billboard magazine began to issue an attachment called the World of Soul. The 1968 edition came out on August 17 and summarized in figures and words much of what I experienced that summer. (These 1967 and 1968 magazines have kindly been provided by Per Oldaeus). It lists the best sellers (during 1/1 - 1/6 1968) and the most popular artists.

The artists I had seen on stage, met or talked to or talked about with their managers in the summer of 1968, are marked with a * and among the category "other” artists only those artists are included.

(I had seen Otis Redding in 1967 and Wilson Pickett in 1969 in Sweden.)

TOP R\&B ARTISTS OF 1968 (According to Billboard) - and number of singles entering the charts. ("Soul” is still called ”R\&B”) 
January 1-6, 1968. (number of hits)

1. Aretha Franklin (Atlantic ) (4)

2. *James Brown \& The Famous Flames (King) (6)

3. Temptations (Gordy) (4)

4. *Otis Redding (Volt) (2)

5. Marvin Gaye \& Tammi Terrell (Tamla) (3)

6. Impressions (ABC) (2)

7. *Smokey Robinson \& The Miracles (Tamla) (2)

8. *Wilson Pickett (Atlantic) (4)

9. *Delfonics (Philly Groove, Moonshot) (3)

10. *Gladys Knight \& The Pips (Soul) (2)

(Others *: 15. Joe Tex, 21. Willie Mitchell, 22. Jerry Butler, 24. Archie Bell \& The Drells, 26. Ray Charles, 27. Marvelettes, 30. Bobby Bland, 36. William Bell, 43. Stevie Wonder, 46. Jr. Walker, 48. Esquires).

Billboards Album-chart, January 1-6, 1968. (Number of LPs listed)

1. Temptations (Gordy) (4)

2. Aretha Franklin (Atlantic ) (3)

3. Dionne Warwick (Scepter) (4) 
$456 \cdot$ JONAS BERNHOLM

4. *Otis Redding (Volt) (3)

5. Four Tops (Motown) (2)

6. *Jimi Hendrix Experience (Reprise) (2)

7. *Wilson Pickett (Atlantic) (2)

8. Diana Ross \& The Supremes (Motown) (2)

9. Wes Montgomery (A\&M, Verve) ( 3)

10. *Smokey Robinson \& The Miracles (Tamla) (2)

(Others*: 14. Gladys Knight \& The Pips, 16. James Brown, 19. Joe Tex, 22. Ray Charles, 30. Booker T \& The MGs, 36. Stevie Wonder, 38. Willie Mitchell, 42. Bobby Bland.)

(I had seen Jimi Hendrix in 1966 in Sweden.)

(James Brown was not an LP-artist while artists like Four Tops and Dionne Warwick, who sold better to white people, did better on the album chart than on the single-list, where they entered place no. 34 and 17 respectively. Myself I had concentrated to see the hit makers before the more sophisticated album artists.)

The best selling 45s, January 1-6, 1968:

1. *”(Sittin’ on the) Dock Of The Bay,” Otis Redding (Volt)

2. “We’re A Winner,” Impressions (ABC)

3. “I Wish It Would Rain,” Temptations (Gordy) 
4. “(Sweet Sweet Baby) Since You've Been Gone,” Aretha Franklin (Atlantic)

5. “Chain Of Fools,” Aretha Franklin (Atlantic)

6. “Dance To The Music,” Sly \& The Family Stone (Epic)

7. *’La La Means I Love You,” Delfonics (Philly Groove)

8. *”I Thank You,” Sam \& Dave (Stax)

9. *’I Got The Feelin',” James Brown \& The Famous Flames (King)

10. "Sweet Inspiration,” Sweet Inspirations (Atlantic)

(*: I had seen the hit maker)

Others:* (Whom I had met, seen on stage or talked to their managers):

12. "If You Can Want Smokey,” Robinson \& The Miracles (Tamla)

13. “Soul Serenade,” Willie Mitchell (Hi)

15. “Tighten Up,” Archie Bell \& The Drells (Atlantic)

16. “There Was A Time,” James Brown (King)

18. “End Of Our Road,” Gladys Knight \& The Pips (Soul)

19. “My Baby Must Be A Magician,” Marvelettes (Tamla) 
458 - JONAS BERNHOLM

23. "I Second That Emotion," Smokey Robinson \& The Miracles (Tamla)

25. “I Can’t Stand Myself,” James Brown (King)

30. "Lost,” Jerry Butler (Mercury)

31. "Drifting Blues,” Bobby Bland (Duke)

35. “Shoo-Be-Doo-Be-Doo-Da-Day,” Stevie Wonder (Tamla)

36. "I Heard It Through The Grapewine,” Gladys Knight \& The Pips (Soul)

38. “That’s A Lie,” Ray Charles (ABC)

41. “Come See About Me,” Jr.Walker (Soul)

46. "Showtime,” Detroit Emeralds (Ric Tic)

50. "What Is This,” Bobby Womack (Minit)

71. “A Tribute To A King,” William Bell (Stax)

79. “And Get Away,” Esquires (Bunky)

Best selling albums, January 1-6, 1968:

1. In A Mellow Mood Temptations (Gordy)

2. Lady Soul Aretha Franklin (Atlantic)

3. *History of Otis Redding (Volt)

4. Greatest Hits Diana Ross \& The Supremes (Motown) 
5. Groovin’ With The Soulful Strings (Cadet)

6. A Day In The Life Wes Montgomery (A\&M)

7. Golden Hits Part 1 Dionne Warwick (Scepter)

8. Greatest Hits Four Tops (Motown)

9. Greatest Hits Temptations (Gordy)

10. *Are You Experienced Jimi Hendrix Experience (Reprise)

Others*:

14. Greatest hits Vol 2 Smokey Robinson \& Miracles (Tamla)

18. Everybody Needs Love Gladys Knight \& Pips (Soul)

24. Live \& Lively Joe Tex (Dial)

27. I Can't Stand Myself When You Touch Me James Brown (King)

33. Make It Happen Smokey Robinson \& Mircles (Tamla)

35. James Brown presents his show of Tomorrow (var. artists) (King)

41. Doin’ Our Thing Booker T. \& The MGs (Stax)

45. Portrait of Ray Charles (ABC)

The most successful record companies - and their number of single-hits, January 1-6, 1968: 
460 - JONAS BERNHOLM

1. Atlantic (22)

2. Tamla (9)

3. Stax (12)

4. $\mathrm{ABC}(7)$

5. Gordy (8)

6. King (6)

7. Cadet (7)

8. Soul (4)

9. Volt (3)

10. Chess (5)

11. Duke (4)

24. Hi (1)

Or Atlantic (22), Tamla/Motown/Gordy/Soul group: (21), Stax/ Volt: (15), Chess/Cadet (12), ABC (7), King (6), Duke (4), Hi (1).

The most successful record companies - and the number of LP listings, January 1-6, 1968

1. Atlantic (21 LPs)

2. Motown (6) 
3. Gordy (6)

4. Scepter (4)

5. Reprise (3)

6. Volt (3)

7. Tamla (4)

8. Cadet (5)

9. $\mathrm{ABC}(3)$

10. A\&M (3)

16. Stax (2)

25. Hi (1)

28. Duke (1)

Motown and its various companies Gordy-Tamla-Soul-V.I.P (16 LPs) sold considerably more LPs than the southern states labels Stax-Volt and Duke and Hi (7 LPs).

Overall, I think I got a good picture of the current soul scene. It's fair to say that I had seen circa $20 \%$ of the most popular artists and visited several leading record companies. Had I stayed for a year I could have seen almost all popular artists and inspected many more local scenes too. (Had I stayed in New York and visited the Apollo Theater every week I would have accomplished it there too.) 
The big misses were that I never saw Aretha Franklin and the Temptations on stage, and that I was not let in at Motown in Detroit (but only visited their west coast office). Aretha was by far the best female singer, and had a typical and ideal background. She was the daughter of Detroit's most prominent church leader, C. L. Franklin, who is considered the greatest religious orator of his time alongside Dr Martin Luther King Jr. One of C.Ls girlfriends, Clara Ward babysat and became Aretha's mentor. Clara and Mahalia Jackson competed for the title of top female gospel singer.

When Billboard in 1967 started The World Of Soul edition they intended to document the blues and its many subgroups. They paid great attention to the blues-revival wave that swept over Europe with the Rolling Stones at the forefront. "Chess Records expects that teenage audiences will soon hear Muddy Waters, Howlin' Wolf, John Lee Hooker and Sonny Boy Williamson when you see how good their phenomenal Real Folk Blues Series sold in the universities.”

Perhaps they were not aware of the fact that the connection between blues and soul music is weak. The main foundation of soul music is gospel. Already in the 1950s, gospel trained singers started invading the $R \& B$ charts.

But it started long ago.

In the mid-1700s a Christian revival movement came from Europe. Missionary organizations from London sent hymnbooks to America. Dr. Isaac Watts had reworked the Bible Psalms to 
rhythmic four-line verses. This book hit like a bomb in the slave colonies.

They were not allowed to read or write so they learned the book by heart. A lead singer sang one line and the assembly repeated it. This call and response style was also used in the work songs. In correspondence between the US and London, the missionaries spoke of how sought after and popular Dr. Watts' book had become.

From there came the Negro Spirituals - the foundation of Gospel Music. Watts' book is still widely used in the church as well as the Baptist Church song book from 1921 - “Gospel Pearls.” (143 of the 163 songs there are by white composers).

Today, the old English hymn "Amazing Grace" is still the most popular gospel-song. Many believe that Dr. Watts' hymn book is the single most important influence that Afro-American Music have received from Europe during the last 250 years, other music from Beethoven to the Beatles included.

In 1865, when slavery was abolished, Negro Spirituals were a popular form of music. In 1867 the song-book Slave Songs were published and in 1871 singers from the Negro Fisk University started touring all over the world.

On the April 9, 1906, a revival started in the black churches in Los Angeles when Jennie Evans began speaking in tongues. The service was henceforth increasingly focused on being filled with the Holy Spirit, ecstasy and to speak in tongues. Gospel music was a powerful tool for this, while the traditional Negro 
Spiritual were sung in a more "dignified" manner in songs like "Nobody Knows The Trouble I've Seen," "Swing Low Sweet Chariot," "Go Down Moses.” etc. The gospel singers pressed harder, experimenting and screaming to get a maximum emotional expression and response.

Around 1930 this can be heard on record. And in 1945 at the end of the World War II, a new generation of male and female gospel singers are ready.

Their way of singing is rapidly taken up in Rhythm \& Blues. The first big star is Roy Brown, and Dinah Washington started as a gospel singer. Then came The 5 Royales, Clyde McPhatter, Sam Cooke, Ray Charles, Little Richard, Hank Ballard, Jackie Wilson and many others.

Twenty years later the whole genre of R\&B is renamed "soul." Even many dance steps were born in the church. When James Brown was gliding across the stage on one leg so had ordinary churchgoers in ecstasy done in the 1940s in the COGIC and other black churches. In the Billboard (1968) is a list of soul artists and their managers and booking agencies. Big companies like William Morris Agency and Shaw have existed for a long time. They usually had their offices in New York and Los Angeles and also worked with film actors. It was a mistake that summer that besides Buffalo Booking Agency in Houston I did not visit any other.

The artists I came in contact with, or are mentioned in the text had the following Personal Managers (PM) and Booking Agencies (BA) according to Billboard: 
Buddy Ace - PM: Fats Washington BA: Buffalo Booking and Fats W.

Vicki Anderson - PM: James Brown BA: Universal Attractions Ruby Andrews - BA: Associated Booking Archie Bell \& The Drells - PM: Skipper Lee Frazier William Bell - PM: Henry Wynn BA:Universal Attractions Bobby Bland - PM: Evelyn Johnson BA: Associated Booking Booker T \& The MGs - PM: BEA, BA: America's Best and Universal Attractions and Phil Walden James Brown - PM: Ben Bart BA: Universal Attractions Jerry Butler - PM: W. Yale Matheson, BA: Associated Booking Corp

Bobby Byrd - PM: James Brown BA: Universal Attractions Alvin Cash \& The Registers - BA: Texas Ents and Queen Booking

Ray Charles - PM: Joe Adams BA: William Morris

Del-Fonics - PM: Stan Watson BA: Queen Booking

Detroit Emeralds - PM: Ed Wingate BA: Queen Booking

Lee Dorsey - PM: Marshall E. Sehorn

Eddie Floyd - BA: Phil Walden and Associated Booking Aretha Franklin - PM: Ted White BA: Queen Booking Lowell Fulsom - PM: Galaxy BA: Big Star and Fats Washington Betty Harris - BA: Phil Walden Joe Hinton - BA: Buffalo Booking Eldridge Holmes - BA: Phil Walden

The Jive Five - PM: Otis Pollard BA: Universal Attractions Johnny Jones \& the King Casuals - PM \& BA: Henry Wynn Gladys Knight \& The Pips - PM: Int'l Talent Mgmt BA: Lee Craver Prods.

Shorty Long - PM: Taylor Cox BA: Motown 
Pigmeat Markham - BA: Universal Attractions (Dick Allen)

Marvelettes - PM: Int'l Talent Mgmt BA: Queen Booking Miracles - PM: Taylor Cox BA: Motown

Willie Mitchell - PM: Joe Cuoghi BA: National Artists Attractions and Associated Booking

The Monitors - PM: Int'l Talent Mgmt

The Mystics - PM: Syndicated Prods BA: Associated Booking Billy Preston - PM: Joe Adams BA: William Morris John Roberts \& His Hurricanes - PM: Robert Garner Smokey Robinson \& The Miracles - PM: Int'l Mgmt BA: Ashley Famous

The Spinners - PM: Int't Talent Mgmt BA:Queen Booking /Associated Booking

Edwin Starr - BA: SAC (Shaw Artists Corp)

Temptations - PM: Int'l Talent Mgmt BA: William Morris Joe Tex - PM: Bea BA: Universal Attractions

Irma Thomas - PM \& BA: Vic Despenza

Jamo Thomas - BA: Queen Booking

Rufus Thomas - BA: Deanie Parker

The Vibrations - PM: Carl Davis BA: Queen Booking Jr Walker \& All Stars - BA: Ashley Famous

Jean Wells - PM: Clyde Otis BA: Universal Attractions Larry Williams - BA: Lee Craver Prods.

Jackie Wilson - PM: Nat Tarnopol BA: Associated Booking Stevie Wonder - PM: Int'l Talent Mgmt BA: Ashley Famous Brenton Wood - PM: Sure Shot BA: A.P.A. (Agency of the Performing Arts)(Only Chuck Berry was expressly "selfmanaged" of all the listed artists.)

Local booking agencies in smaller cities were: 
Atlanta - Henry Wynn (431 Glen Iris Dr, NE)

Chicago - Texas Enterprises.

Dallas - Fats Washington.

Memphis - National Artists Attractions.

New Orleans -Vic Despenza.

Phil Walden and Otis Redding had offices in the same building: (Redwal Bldg, 535 Cotton Ave, Macon, Georgia).

International Talent Management in Detroit ran Tamla Motown artists reservations and Galaxy Artists was a management and booking company in the same house as Chess in Chicago and they had another BA - Big Star Attractions. The soul (and former gospel) singer Mitty Collier worked at Chess as a personnel manager.

I failed to examine the economy and the organization behind the larger concerts and packet-shows. Billboard noted (The Live R\&B Scene -1967) that Otis Redding and a package show pulled in a gross of \$250,000 per month in 1966 (or \$ 8,500 per gig). The year after (1967) Otis Redding with supporting acts had brought in \$ 500,000 for 50 performances (or \$10,000 per gig).

During the rock and roll era, ten years earlier, the packages were smaller and they visited small towns. But they had built many outdoor venues in the South. A larger Soul package could now contain up to twelve different artists, and cost the organizer between $\$ 4000$ and $\$ 7,500$ to hire. These packages could then make a gross of between 10 and $\$ 15,000$ per gig (or 5,000 spectators who paid between $\$ 2-\$ 3$ ). With the really big arenas 
a gross could be upwards of $\$ 40,000$ (10-20000 spectators who paid \$2-\$4).

In Memphis, Joe Tex had been the main attraction at the MidSouth Coliseum, along with two other artists who were at the top of the charts at the time; Delfonics and Pigmeat Markham, plus circa ten other artists.

Billboard listed the ten soul superstars that could top the bill at such a venue:

James Brown was by far "the undoubtedly biggest audience magnet on the R\&B circuit.” He didn't need other big names on the posters to share his revenue with.

The other nine were (1967): Otis Redding, The Temptations, Four Tops, The Supremes, Ray Charles, Wilson Pickett, Jackie Wilson, Joe Tex and Billy Stewart. (I think Billy Stewart should be replaced with Sam \& Dave and comedian/singer Moms Mabley is another female black superstar alongside the Supremes).

Billboard also noted that Ray Charles and Fats Domino in particular now had more white fans and therefore were less suited for a soul concert.

The big package shows usually had a twenty percent share of white spectators in the South. Sometimes a white artist, who was accepted by blacks, such as Mitch Ryder \& The Detroit Wheels or the Young Rascals was added to a package.

A few years earlier, there were "Motown" packages with the 
most popular Tamla-Motown artists. But now their individual artists had their own package shows.

The leading producers of these packages shows were A.P.O Shows (Miami) and Henry Wynn's Supersonic Enterprises (Atlanta). Three companies booked ninety percent of the R\&B industry's most popular artists: Universal Attractions, Shaw Artists Corp. (S.A.C.) and Queen Booking Agency.

University students had begun to request $R \& B /$ soul artists to their dances. Even fairly well known black artists could earn $\$ 2000$ per night. Some black artists preferred to work on the weekends and have time off in the weekdays; instead of wearing themselves out on the chitlin' circuit; with a new venue every night.

James Brown and the Supremes, who were the most popular, could earn \$ 12,500 per night for a student gig.

Blues artists like John Lee Hooker and Jimmy Reed were requested at universities and Hooker could ask for $\$ 750$ for one night. If a blues singer received $\$ 500$ a week at a blues club he could now earn $\$ 500$ for an evening's work. Many night clubs with mainly white audiences had opened up for black artists. R\&B and soul artists generally did better than white pop artists as the R\&B/Soul crowd was older and had more money to spend. Blues performers also got bookings at jazz clubs since several years.

Some tour companies like Queen Booking seem to have worked with black artists exclusively. The owner Ruth Bowen took the 
company name from her former employer Dinah Washington. I had seen Queen artists like the Marvelettes, Jerry Butler, Stevie Wonder, Jimmy McCracklin and the Miracles perform.

Phil Walden Enterprises (1967) was the southern soul's foremost ambassador with about 35 names in his stable like Otis Redding, Arthur Conley, Jimmy Hughes, Percy Sledge, Eddie Floyd, Joe Simon. Phil also noted that Otis Redding had done more to improve race relations in the South than 100 sit-ins.

A year later (1968) Billboard's editorial team confirms that 1967 had seen the breakthrough of soul music. Now it even dominated pop music.

Aretha Franklin had four million records sold in 1967. Otis Redding died and James Brown had reinforced his position as the hottest artist on the one-nighter circuit. Popular blues artists were Jimmy Reed, Bobby Bland, BB King, Bo Diddley, Little Richard, Lowell Fulson and Albert King.

But the Apollo Theater had difficulty booking artists who were better paid at the universities. A gig at the Apollo was often a way to launch new discs and get additional advertising rather than to make money.

The Apollo put a lot of time in promotion, advertising, radio and advertisements in various record stores and on cooperation with record companies.

The Apollo had 1800 seats. The tickets cost \$2 in the daytime and \$3 in the evening. If there are 1800 visitors in the afternoon 
and 1,800 visitors in the evening, it makes $\$ 9,000$ per day. (I paid $\$ 2$ in the afternoon and stayed until they closed.)

A popular artist made the people stay longer. James Brown used to have queues winding around the block all the time he was there. But it was rare that the Apollo was sold out the whole week. They sold just popcorn - no booze or beer. I do not think they grossed more than $\$ 9,000$ per day.

I visited the upper balcony once. There were not many people there on a Sunday afternoon (Perhaps ten to fifteen percent of the seats were taken).

On weekdays, unemployed and school children playing hooky could not fill that many seats either. On the Wednesday Amateur night the theater was full. There were many people at the premiere with The Miracles and Jr Walker on a Friday afternoon. Gladys Knight also drew a lot of people. But when the Marvelettes appeared it was pretty empty even on parquet. The Apollo, and even more than the Regal in Chicago, had trouble paying what several artists were now accustomed to, and they had at least four or five performers on the program.

I have tried to remember how many visitors there were was at a club.

Often it was not more than 350 people who paid \$1-\$2 during a weekend performance. It meant that the performers had to share a maximum of $\$ 500$.

On a Monday-Tuesday night there were only one hundred people watching Ike \& Tina Turner. 
Radio stations

I always listened to the radio in the hotel room. I wanted to hear new records and if there was a soul show in town. But I didn't hear any live shows with famous artists from the radio studio or live broadcasts from a club. I do not remember that artists on tour, or at the Apollo and Regal, were presented or interviewed. Artists like William Bell was not interviewed by a radio station DJ or newspaper. In short, I never met anyone backstage who wanted to get the attention of the artist (except at the James Brown concert.)

There might be a club photographer taking pictures of patrons. But it was rare. I never saw an extra microphone with the radio station's letters on stage and I was never present when a live recording was made. Sure, there were often people from the industry in the clubs. Local DJs, other artists visiting a friend or someone working at a record company. But I didn’t note any major talent scouting at the time.

Shows were advertised on the radio, like Syl Johnson in Memphis, Jackie Wilson in San Jose and James Brown in San Francisco. The advertising was frequent and appeared to be subsidized because it was newsworthy or because the DJs were involved. Al Perkins handled the Syl Johnson advertising and was also the MC at the Paradise Club in Memphis that night.

James Brown appeared frequently on radio, but in the form of pre-recorded tapes. He sometimes had special DJ editions of a record made where he presented himself and the song before the music started. 
But there were frequent broadcasts from churches with services and worship. Every city seemed to have a pure gospel music station for this. But I listened mostly to the soul stations that had gospel in the mornings and on Sundays only.

Female DJs were heard in the morning gospel music program when housewives listened. Often a variety of goods were on sale - like holy water, prayer cloths and inspirational reading. Sometimes it sounded as if the DJ had a commission on sales.

Playing list

The radio station's playing list was usually not completely predetermined. While the program and music-director were responsible for the play-list, the individual DJ could often choose their own favourites from the list, and sometimes even play a song not there. In each city there were records not heard elsewhere - and never heard again. Listeners could influence the selection by calling the station or drive by sounding the horn or blinking the lights.

But probably not as much as when Elvis or James Brown was first played on the radio. Then the station's switchboard lit up like a Christmas tree.

Billboard also noted that new artists had the chance to break through with their first disc if it was good enough. That a R\&B record that became a pop hit often sold better than a pure pop hit because it sold at two markets.

In 1968 radio stations usually had 40, 50 or 60 songs to chose from. Later, when the number were reduced to 20 , no one had to 
wait more than one hour before their favourite was played. With fewer records it became more difficult for an unknown artist to establish themselves.

Many DJs I met had their own record career as Rufus Thomas, Butterball, Nickey Lee, and Al Perkins. There were many others like Sly, Wolfman Jack, Magnificent Montague, Jerry-O, etc.

Many DJs moonlighted as MCs at shows.

A disc jockey seemed to be a mobile person who moved around from town to town. Maybe because the audience wanted to hear new voices. A few white people worked as DJs at soul stations if they sounded black. Soul stations played almost exclusively black artists: exceptions this summer were Bill Medley, the Young Rascals, and Delaney \& Bonnie. But the owners were usually white. They had one or two stations like Zenas Sears in Atlanta or Donald Sundeen in Houston. I suppose that many radio stations later were acquired and became part of a chain which centrally determined which discs to be played.

The sound

The club sound in 1968 was usually good. You could hear the instruments and the vocals and earplugs for protection were not needed.

The balance between instruments was good, and the dynamics of the music too. I never noticed that the sound was bad at any concert. Or that I went home unhappy for this reason. A gospel concert in a church could be almost un-amplified. 
Today everything is different. The sound engineers can do a marvellous job with an electric guitar but become confused when there is a horn section and back ground vocalists. Then it can sound like a flock of sea gulls have entered the hall.

\section{Finances}

The flight to and from the United States cost around \$200. When I arrived in the US, I had \$1,050 to spend. (The exchange rate was 5.20-5.40 SEK / US \$). The prospects of sitting on a Greyhound bus between the different cities for 7-10 days made me book a round trip air-ticket. It cost \$317.

After buying a radio (\$13.50), \$7 or \$8.50 / day was left or:

\$2 for a hotel room

\$1-\$1.50 for food and booze (A loaf of bread cost about \$ 0.25 and a hamburger as much. After a few weeks I lowered the food ration including drink for under $\$ 1$. The tap water was not always drinkable).

\$2-\$2.50: Club-admission and beer

\$0.50: bus/subway

\$2: other (telephone, laundry, bus to/from airport, newspapers, maps and records).

Entertainment in the black ghetto was cheap. I paid \$2 for a balcony ticket to the Apollo theater. You could see five different artists and sit all day until the theater closed at midnight. The entrance to the Regal theater in the afternoon also cost \$2. In 
comparison, a cinema ticket at Times Square in New York, with two older movies, cost 85 cents.

The gospel concert in Chicago with Mahalia Jackson as a surprise guest cost $\$ 3$ while the visit to Cottage Groove church cost $\$ 1.25$. (Many gospel groups had to share a modest gross of circa $\$ 150)$.

Entry to the clubs in Chicago cost $\$ 1$ (High Chaparral, Bonanza, Checkmate), while the beer cost 75 cents (and 55 cents at Checkmate). A one way El-train ticket cost 30 cents.

Weekly rentals at hotels were cheaper because sheets had not to be changed and rooms were not cleaned but once. Other tourists were not staying there. The only disturbance were tubercular coughs from room neighbours or disorder in common washrooms and toilets.

An important conclusion: by living a very frugal, almost in semistarvation you can realize a lot of visions and dreams. This summer had been a good training.

I felt very much at home at the small American record companies.

Soul music

In African-America I think that gospel music has been much more important than blues. Not only in soul music where virtually all artists had a gospel background. Many grew up with a father as a priest or mother as cantor or choir director. Those 
who did not sing gospel in the churches still sound as if they came from there (Ray Charles).

Soul music also expressed the optimism of the emerging black middle class in the 1960s. You could improve your life, get an education, make money, create a family.

This optimism for social change, that was so evident during the Kennedy-Johnson era in the 1960s, ended with Martin Luther King's death.

The blues on the other hand often took up personal shortcomings in life like problems with alcohol, women and drugs. Instead it found a younger white audience that shared its values.

The golden age of soul music (1963-1968 followed the golden age of Gospel Music (circa 1945-1965).

The Afro-American culture

My US trip could have been made anytime between 1918 and 1968. Musically, it would he been equally gratifying. During this long period black music was good, exciting and interesting both on record and stage. But afterwards things declined.

1968 was a transition period. Artists took steps in the wrong direction. James Brown led the development with his funk sound. The Temptations followed with Cloud Nine and later the Isley Brothers with It's Your Thing.

That soul music had become a popular trend among whites, left the music business no peace. Soul was now being produced 
directly for white listeners who fled from a pop scene where many white artists performed stoned on stage - thinking they were inspired, talented, improvising musicians.

Steve Cropper told me that he felt that soul music was facing a new era. Otis Redding's “Dock Of The Bay” proved that Stax could make pop music without necessarily losing the soul. It was a direction Steve wanted to take. But Redding's death stopped this. I also preferred this development before funk (or later rap) music. A good soul singer can put a lot of feeling into mediocre pop material.

Wilson Pickett proved he could sing both bubblegum pop (“Sugar, Sugar”) and rock (“Born To Be Wild” or "Hey Jude”). In the mid 1960s many fine pop-soul songs had been created in Detroit and New York.

Today show business is imbued with gay and transgender impulses. It started a long time ago. I have met some great $\mathrm{R} \& \mathrm{~B}$ and soul artists who belonged to this scene. An afternoon at the home of Billy Wright (1978) and his gang of female impersonators and transvestites opened my eyes.

Tough R\&B artists like Bobby Marchan and Billy "Prince of the Blues” Wright appeared in women's clothing already 60-70 years ago, and certainly also Esquerita and Little Richard. Transvestites with blond wigs ruled during Apollo Amateur nights.

There are many heavy-metal white singers who are trying to sound like James Brown and Wilson Pickett. But a white singer 
without a gospel background often only sounds vulgar and cheap. Like a pusher outside a strip club or a street vendor of trinkets. They press their voices and they scream while a singer with a gospel background has a completely different range of expressions.

In the late 1960s there was no longer any reason to follow the current popular music - black or white. I went back in time and instead "discovered" the almost forgotten musical treasure after World War II. In that postwar era of Rhythm \& Blues and Gospel, I found everything and sometimes more of what was now missing in soul music, and I released 190 LPs. But that is a completely different story.

But before soul music died, there were two more important artists coming to Sweden in early 1969 - Joe Tex and Wilson Pickett. 



\section{Postscript (I): Joe Tex}

I got to know Joe when he appeared at the Student Union on Holländargatan. Joe had a fairly large group of fans in Sweden. Not only among the pure soul fanatics. My impression is that many of them rather bought Joe Tex latest LP than James Brown's.

He was philosophical and a keen observer of human behaviour. Man's strength and weaknesses are described in his lyrics. He was a very good songwriter and mixed his brand of soul music with a healthy dose of Country and Western. He was a good singer, but Texas has not been the birthplace of the truly great soul singers like Georgia and Alabama. I guess church gospel training is more intense there.

We set up a meeting one hour before the show next day at the Domino. This is what Joe Tex said about his life and career 48 years ago:

"After the talent show I won in Houston, I got some money and went to New York. I went straight to the Apollo Theatre 
to try my luck on their Wednesday Amateur evenings. I won four Wednesdays in a row and as the prize I got one week's engagement at the Apollo. Arthur Prysock was there one night, and he arranged an audition for King Records and their producer Henry Glover. We recorded “Come On In This House.”

Joe had written songs of his own, and Henry liked what he heard. But it took a few weeks to release the record and Joe did not want to go home without having accomplished anything. So he stayed in New York. Joe sees himself as a self-made man. He didn't have a mentor or protector who took him under his wing. He had to work his way up by his own efforts. He began to take part in talent shows already in high school.

I had hoped to meet Joe in Memphis in 1968 after a big concert at the Mid-South Coliseum. Now Joe told me what had happened.

Early in his career, Joe was on his way to New York from North Carolina, but in Washington he ran out of petrol. Fortunately Roy Hamilton appeared at the Howard Theatre. Joe was a big fan of Roy and wanted to take this opportunity to ask Roy for advice and maybe some money. He got both. Roy - The Golden Boy also had a heart of gold and he gave Joe \$20. Three years later they were on the same show in Florida but then Roy had forgotten everything and refused to take the money back.

In 1968 Roy had a long engagement in Memphis at the Top 4 Um. Joe went there and not to the Hippodrome at Beale Street where I went looking for him. Otis Redding and Sam Cooke also always had time to listen to and help others, said Joe. 
Joe had only worked as an artist. He had not taken any other jobs unless absolutely necessary. For example, he took a job in a furniture store on Long Island while he waited for King Records to release his first record. At the time he was nineteen years old but looked like fifteen and no clubs would let him in. He stayed as an assistant in the furniture store until the owner was released from prison. He was there for two weeks on drunkenness. Then Joe took a job at a Jewish cemetery at $\$ 1$ per hour. He cut grass and kept tombs clean but stayed only half a day - enough for a bus ticket to visit Henry Glover. Glover had waited for him as "Come On In This House" did well in the southern states, and after three weeks he had a check of \$200 waiting for Joe.

Joe took the first train home "In Baytown everybody had heard my little record. I thought I had reached the top but didn't suspect that I had ten years (1955-1965) of hard work ahead of me.”

But he is glad he did not became a star overnight. He remembers Little Willie John, who wasted two million dollars and died penniless in prison. During those ten years, Joe lived in lots of cities, stranded without any money.

That's why so many people say that Joe Tex is from their city and that they remember him - "He lived in the neighbourhood and was always broke.”

Joe lived in Greensboro, Charlotte N.C, New Orleans, Nashville and Atlanta. It was easiest to get jobs in the South, especially around harvest time when people had a little money to spend. 
Now he lived in Baton Rouge with his wife and their four-year old son, but his hometown was after all Baytown in Texas.

This was Joe's first European tour, but he had been on his way twice before. Once they could not afford his band and he did not want to use local bands. The second time it was an air strike and Joe did not know if he could return on time again.

"But had I known how nice it was in Europe, I would gladly have stayed a little longer. It is much easier to work here than in the US. It is almost impossible to make a coloured audience satisfied. You have to work so hard that it's incredible. You have to knock your head on the wall for the audience to be satisfied and happy. This tour has really been like a holiday for me.”

We talked about James Brown. I really liked his fantastic recording of "Baby You're Right” written by Joe Tex. Like most other artists Joe didn't like him or trust him. In the mid 1960s Solomon Burke had said the same while in England. Joe said that James complains of heart trouble but it's just to get sympathy. He has a liver problem because he drinks too much champagne. In fact, said Joe, "James has no heart at all. He is very cold."

Shortly after my meeting with Joe, I read James Brown's column in a soul newspaper that he and Joe Tex were friends again. They had reconciled.

In the early 1970s I heard the Joe Tex recording "You Keep Her” on Checker. It sounded like an open letter to James Brown 
who had tried to return Joe's girl friend after a period of use. I guessed that this was the basis of the enmity.

Joe was very pleased with the enthusiastic reception in Sweden. It was easy to appear for a white audience. He believed that soul music was at its peak right now and that it would stay a while, but then it would change. This was a pure PR trip. He charged no more than $\$ 1,000$ per night which was very cheap.

His reputation as a performer was widespread. His special gimmick was his interaction with the microphone. He did not use a long microphone cable to walk out among the crowd. His microphone was standing on the floor, with a heavy foot. Sometimes he set it in motion, and the microphone swung back and forth and from side to side. The audience followed breathless the microphone's path through the air - Would it arrive in time for Joe to sing the next verse? Would he get hold of it when he was kneeling on the floor? Or would it even smash his head?!

Joe's tour was a great success in Sweden and I guess in the rest of Europe. He really connected with the audience. Everything he did seemed spontaneous and unrehearsed. His band was just great.

We talked about his songs. I had some earlier recordings on King-Ace-Anna-Parrot-Checker that he did before Dial.

Joe never sang in vocal groups or gospel music groups. He lacked that kind of training. Texas was not the best place to acquire such a background. 
In New Orleans, he was part of the group around Huey Smith who claimed that Joe sang on For Crying Out Loud as one of the Clowns; together with among others Curly Moore.

As a songwriter, he had written for Jerry Butler (The Wicked Man).

“Old Time Lover” dealt with his childhood sweetheart. They were about to marry. But she moved to Chicago and met a man in the computer industry. When Joe got back from a tour in 1960 to marry her, she was already engaged to this man.

His favourite singer was Ray Charles.

Joe was not worried if his name would disappear from the neon signs and his popularity wane.

“I can’t understand artists who hang on in New York when their careers are over. I will go down to the South again. I have 12 acres of land and a tractor so I just go back where I come from to the cotton fields. This time 'The (white) Man' will not be able to take my money.”

Joe was not particularly fond of pop and psychedelic music. But it brought in new people and new ideas. Which can’t be wrong. Joe thought soul music was at its top right now, but in a few years it would sound a little different.

His friends Lee Dorsey, Otis Redding and Don Covay had said that it was good in Europe. He had not had any language problems during the tour except in France. 
Before we parted, when Joe was due on stage, he told me that he always checked that his stage clothes are OK. "That the shirt is really pulled down in my pants, and that all buttons are folded.” Once at the Uptown Theatre in Philadelphia a girl waved frantically from the audience to him. He waved back before he realized that she pointed to his fly that was standing wide open. He did not want that to happen again.

Joe did two shows in Stockholm. The first on the 29th of January 1969 was at the Student Union. On the 30th he was at the Domino Club at Hornstull. The Domino gig was much longer and more relaxed, fun and inspired. Swedish TV also filmed him.

January 29, 1969

The band was introduced as the Big Joe Tex Recording Band and started an instrumental set with:

Soul Finger, Philly Dog, Up Up and Away, Yesterday, Brand New Bag and a Tribute to a Soul Man, which was an Otis Redding medley with; Satisfaction, Dock of The Bay, Security, Respect, Don’t Mess With Cupid and I Can’t Turn You Loose.

"And now to the bandstand a real soul man from the state of Texas in America - Joe Tex!!”

Dressed in a yellow shirt and a green suit Joe entered the stage and sang: "Letter Song,” “I’ll Never Do You Wrong.”

On “Tighten Up” Joe invited at least six girls from the audience 
to chose band members to dance with. Finally two girls accepted.

Joe presented: “Green Green Grass Of Home” ... "from my forthcoming Soul Country album," and his latest single "That's Your Baby,” plus “I’ll Never Do You Wrong.”

Then Joe invited us to request time.

The audience wanted: “Who’s Makin Love” (the Johnnie Taylor song) and his own classic hit "Hold What You Got."

Joe started talking: - "When you come home early and your woman stays out 'til 2-3 in the morning," before he let the song's moral speak for itself. The tension-building line "One - Two Three ..” was effective.

He did Eddie Floyd's “Bring It On Home To Me” complemented with dance steps from the Boogalo dance and a duel with heel kicks to the microphone stand that rocked back and forth.

Since Otis Redding was the biggest $R \& B$ star in Europe, he did two of his songs "Fa Fa (The Happy Song)" and "Hard To Handle.”

Joe was sweating heavily now, and his suit jacket was wet, and when he sang "By The Time I Get To Phoenix," he changed the city's name to Stockholm.

Of course he also did "Skinny Legs and All," and started a competition where the woman who had the most skinny legs would win. But he had to change it to a Big Leg contest, since 
few women in Sweden have skinny legs. One of the girls who had danced during Tighten Up won 50 Swedish Kroner (about \$10 USD).

His own set lasted maybe one hour and fifteen minutes. He took off his jacket and pretended to throw it out among the crowd, but it fell down in the orchestra pit. The bow tie and the shirt ended up among the audience. Bare-chested, with a cloak thrown over his shoulders, the band followed him from the stage.

The MC announced that those who had not had enough should come to the Club Domino Club tomorrow.

January 30, 1969

At the Domino Club Joe Tex did two sets:

His orchestra, consisting of three trumpets, three saxes and guitar, bass, drums, played

Tribute to Otis Redding (a medley with "I’ve Been Loving You Too Long,” “Satisfaction,” “Dock Of The Bay,” "Security,” "Respect”)

Showtime!

Joe was introduced as "Well-known from The Apollo Theatre, The Regal, The Hollywood Bowl, TV ... etc"

He came out dressed in a brown-red suit and did "The Letter Song." 
He held the floor microphone with both hands and lifted it into the air.

When the applause ceased, he welcomed everyone to the next 40-50 minutes show.

In Show Me, he picked up a tambourine, and he kept it into "Papa Was Too." There, Joe changed a line of text to "He put Stockholm Daily News in the shoes to cover the holes ..”

"We're looking for the girl with the skinniest legs in Stockholm and we're giving away 50 SEK. “A girl in pants won the competition. They had to pull up her pants to check her calves.

"Go Home and Do It"

"Dock Of The Bay" gave Joe a chance to show that he could whistle.

When it came time for the audience's requests a man wanted to hear

“I Don’t Trust Myself Around You” - but Joe had forgotten most of the text.

Björn Luthander wanted to hear one of my own favourites from the Parrot LP (I Wanna Be Free) but Joe could not do it because his current band had not been with him at the time.

Instead followed:

“Men Are Getting Scarce” 
“A Sweet Woman Like You” - This song was probably the best this evening.

At Domino, he did two sets. When he came out for the second set he had changed his brown suit against a black one.

Joe was in splendid form and delivered a string of hits and wonderful songs like

"I’ve Been Loving You Too Long," "Show It," "You Better Get It” was absolutely perfect, "Yesterday,” "You Got What It Takes," and his latest single "That's Your Baby" - "Which all of you can buy this Monday when it will come by air from the United States.”

\section{“Hold What You’ve Got”}

A friend wanted to hear "Yum Yum" (The B-side of his Little Richard imitation You Little Baby Face Thing)

Joe replied: "It is too old, my band has not been together that long. I recorded it in 1958 on Ace. Take a newer number!”

One guy asked for “Who’s Making Love” (Johnnie Taylor) and Joe started to speak:

“Do you know what your baby is doin' when you're out all night? She might be at the Domino Club listening to some psychedelic music.”

He went to the turntable of the club. There lay "The Crazy World Of Arthur Brown” LP. Joe put down the pick-up and started singing with it: "I'm the god of hellfire and I bring you fire," 
and then he continued with "Who’s Making Love.” (Joe never missed a chance to improvise...)

Next was “Ode To Billy Joe.”

Joe tried to encourage a girl to jump down from the balcony just like Billy Joe had done from Tallahassie Bridge - to make the song more realistic!!

It was midnight - 12 o'clock - The club had to close, but Joe wanted to sing more. The audience would not let him go.

Now followed: "I Don’t Trust Myself Around You," "Men Are Getting Scarce,” “A Sweet Woman Like You,” "I’ve Been Loving You Too Long," "Hard To Handle," “Go Home And Do It," "Dock Of The Bay.”

And a new Johnnie Taylor song and a ten minute long version of "Skinny Legs and All."

In the finale, he threw out cufflinks and a bowtie just like James Brown. (I hope someone saved it and James Brown's 1.5 years earlier). Considering the development of black music in recent years, genetic engineering might clone both Soul brother No. 1 and No. 2. back to life ...

Joe finished with a small James Brown robe routine at the end. He had stayed half an hour over time and seemed to have had as much fun as the audience.

It's great to have to have met Joe Tex, and to have seen him perform under such optimal conditions, with a band he used on 
SOUL MUSIC ODYSSEY USA 1968 • 493

his recordings. This was the best performance I have ever seen in a Swedish club. 


\section{Postscript (II): Wilson Pickett}

Wilson Pickett came to Sweden for the first time on February 10, 1969. He was perhaps the most powerful screamer of them all during the golden age of soul music. He was a hard gospel singer with a pair of vocal chords made of steel, but also at home with a tender soul ballad.

Sonet Konsertbureau had brought him here. I was probably invited by Helan, the PR man at Sonet, because I had visited Wilson Pickett's offices near Times Square in New York in 1968. Wilson had started a record label and an agency to launch new artists. On my visit there, I got a pack of small colour pictures of him from a friendly, corpulent, middle-aged, white woman. It was a good sign because similar offices could be managed by an indolent young beauty who seemed most concerned about not breaking the fingernails during office work. 


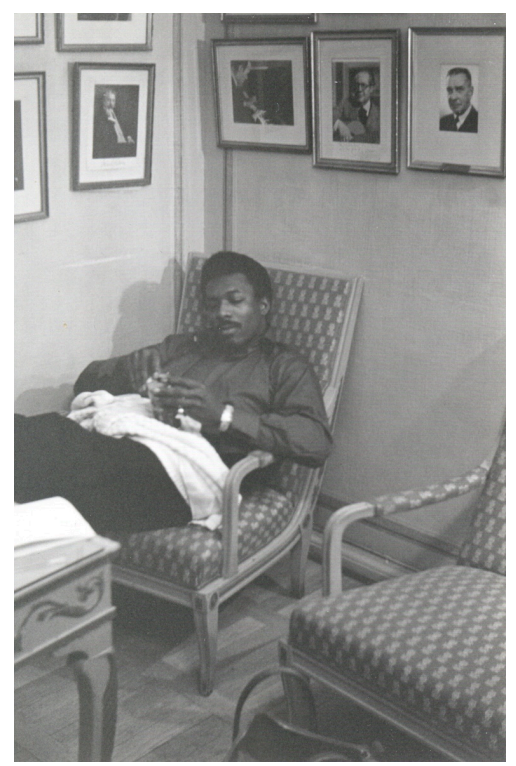

Wilson Pickett backstage at Konserthuset, Stockholm
With my backstage pass I moved freely in the Concert Hall premises. The door to the dressing room was opened by his young protegé and travel companion Danny White. Wilson was tired and sat slumped in a chair with his eyes closed, and a towel in hand. The year before, I had met Wilson's good friend Bobby Womack in Hollywood. Bobby had written several hits for Wilson but his own solo career had not yet taken off.

A greeting from Bobby made Wilson open his eyes. Wilson had been on the road for two weeks. He did not like to travel, as it was difficult to make himself understood abroad. People do not really understand what I mean.

I had prepared some questions.

I was very interested in Wilson's time with the early super-soul group the Falcons (among the members were Willie Schofield, Sir Mack Rice and Eddie Floyd).

I do not know what they were doing before I joined.

His time as a singer with the gospel group the Violinaires brought even less response. 
So I asked about his Double L recordings (Lloyd Price company) plus his single on Verve, that Double L leased, and we talked about the producers Rick Hall, Chips Moman and Steve Cropper. He preferred to record with Rick Hall.

The Soul Clan was a supergroup of Atlantic soul artists including Joe Tex, Don Covay, Solomon Burke, Ben E King and Arthur Conley.

Wilson was on the same label. Would he join the Clan?

"No, I will not record with them. I have too much to do on my own.”

After a while, I left Wilson alone.

The Midnight Movers - Wilson Pickett's backing group - sat backstage. They were upset. They had just been fired. Back in the USA, they and Wilson's manager had to find new jobs. The reason for the conflict was a gig in San Remo that they had not been paid for. The bass player had lost his passport and vanished without a trace.

He was replaced by Mike Watson, from the Swedish pop group the Lee Kings.

It was not at all certain that they would even play tonight. With this terrible threat ringing in my head, I took my seat in the Konserthuset hall.

The opening act was Linkin' Louisiana Peps and the Blues Quality. It was a very long set, while the negotiations continued 
backstage. Finally they left and The Midnight Movers - The Wilson Pickett Orchestra - entered. It was a large soul band with three saxophones, two trumpets and one trombone plus guitar, bass and drums.

They did five instrumentals, including the two biggest instrumental soul hits of 1968, "The Horse” (Cliff Nobles) and “Grazing In The Grass” (Hugh Masakela), and "Soulful Strut” (Young Holt Unlimited) plus a song with great guitar and yet another unknown title.

Wilson Pickett was then announced. He was going to sing tonight!

He started with a wonderful version of 634-5789. Then "People Make The World" was followed by "Midnight Mover."

“Now I like to take it kind of slow and easy. Lord Have Mercy!” And Wilson dove into the Beatles' "Hey Jude"and "Mustang Sally.”

"When you're all alone and the raindrops are falling on the window pane - you need a woman to love - a woman who can sock it to you" - and the classic soul ballad "I'm In Love" followed.

"They told me that when I came to Sweden all the people would have nothing but soul. So now we're gonna have a Soul Hootenanny. Everybody say Yeah! - Yeah!” 
Wilson wanted to take advantage of language problems and misunderstandings. He said:

"What'd you say - don't you think you and me stop the show and go home!”

and the crowd responded, of course: - Yeah! before they had time to think. And Wilson said

“All right! I’m goin’”

and the audience said

“No!”

Then came "Funky Broadway" and the audience was invited up on stage to dance.

"In The Midnight Hour" - Wilson felt fine - he was back in church with the Violinaires.

"You know I feel pretty good right now! You know when I came to town this afternoon I was a little tired. I walked into my hotel. There was a guy sittin' in the bar and drinkin' whiskey and another was drinkin' gin. You know one fellow asked me: "Say Wilson what is soul?" and I answered him: "Soul is feeling! Yeah - Soul Is feeling !!” and Wilson pointed to an Afro (American) in audience and said "You've got it!” and he pointed to another "You got it!"

After "Land of 1000 Dances" Wilson shouted to the crowd:

"Now do you know what soul is!!” 
A very enthusiastic African-American rushed on stage and gave him flowers and lifted Wilson into the air and almost carried him off the stage.

There was no encore.

The atmosphere between Wilson and the band was frosty, but Wilson was very encouraging to the Swedish bassist. It was an OK show but circumstances were not optimal. It was not like the recent concert in USA where the excited crowd started a riot. Pickett in top shape can be pretty hard to beat. He had an incredibly powerful vocal style, inter-punctuated with bloodthirsty screams. It does not matter that he has always been rather motionless on stage.

He had a unique number of soul classics in his repertoire. In The Midnight Hour is among the whole genre's top 10, and the other successes are not far behind. He is a hard soul singer of the highest order.

What took place in Stockholm was just another in a long series of incidents where the Wicked Pickett had tried to live up to his nickname. A pianist was shot during rehearsal in the Pickett home. In the 1980s he was expelled from England in the middle of a tour. Plus there are lots of stories about cocaine misuse, etc.

Cocaine had been the drug of choice among soul artists as they had to be so up beat and energetic on stage. The show is like a church revival meeting but afterwards the artists are left without the support of the parish.

I don't think the Danny White in Stockholm recorded the great 
$500 \cdot$ JONAS BERNHOLM

single on the Atlas label called I'm Dedicating My Life with Steve Cropper and the Stax studio band. He simply looked too young. 


\section{About the author}

Jonas Bernholm is a Swedish researcher, writer, and record label owner (also known as “Mr. R\&B”) who made it his life's ambition to document the rhythm and blues scene in the United States during the 1960s. He has been instrumental in sharing blues music via a number of record labels he has started since 1976, including Route 66, Mr. R\&B, Stockholm, Bluesboy, Crown Prince, Saxophonograph, Jukebox Lil, Gospel Jubilee, and Earth Angel, among others. The distributor for these labels is City Hall Records.

An avid record collector, Bernholm's 26,000 LPs, 45s and 78s and artist correspondence have been on display at The Smithsonian Institute since 1996. In 2013 a documentary on his career was featured for four months at The Stax Museum in Memphis, Tennessee, and a 360-page book was written about Bernholm in 2016 by Jan Kotschack titled Resan Mot Rockens Rötter.

This book is the result of a soul music pilgrimage to the United States in 1968, visiting studios, clubs, and other sites related to 
$502 \cdot$ JONAS BERNHOLM

American R\&B and soul music. Much of the supporting material for this book can be found in the Jonas Bernholm Rhythm and Blues Collection, 1976-1991, Archives Center, National Museum of American History, Washington DC. 